\title{
ЕМКЕМЕСЯЧНЫЙ НАУЧНО-ТЕХНИЧЕСКИЙ
} И ПРОИЗВОДСТВЕННО-ЭКОНОМИЧЕСКИЙ ЖКУРНА
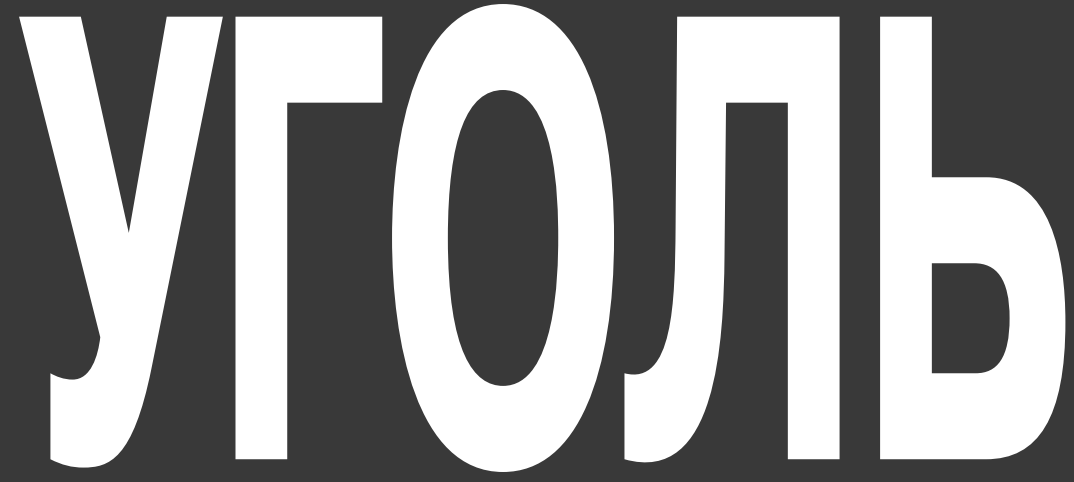

МИНИСТЕРСТВА ЭНЕРГЕТИКИ РОССИЙСКОЙ ФЕДЕРАЦИИ

WWW.UGOLINFO.RU

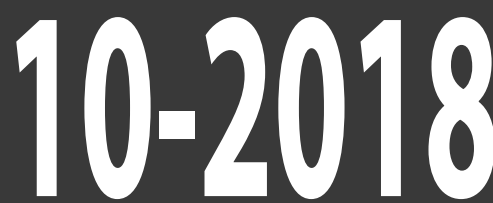

\section{ВРГОНЫПОВЫШШЕННОЙ ГРН3ОПОДВЕМНОСТИ}

ПЕРВНЯ

TЯЖЕАОВЕСНHЯ

КОМПРНИЯ

\section{ВЕСОМคЯ ПОМЕРЖКК} IIEPEBO3OK YTA
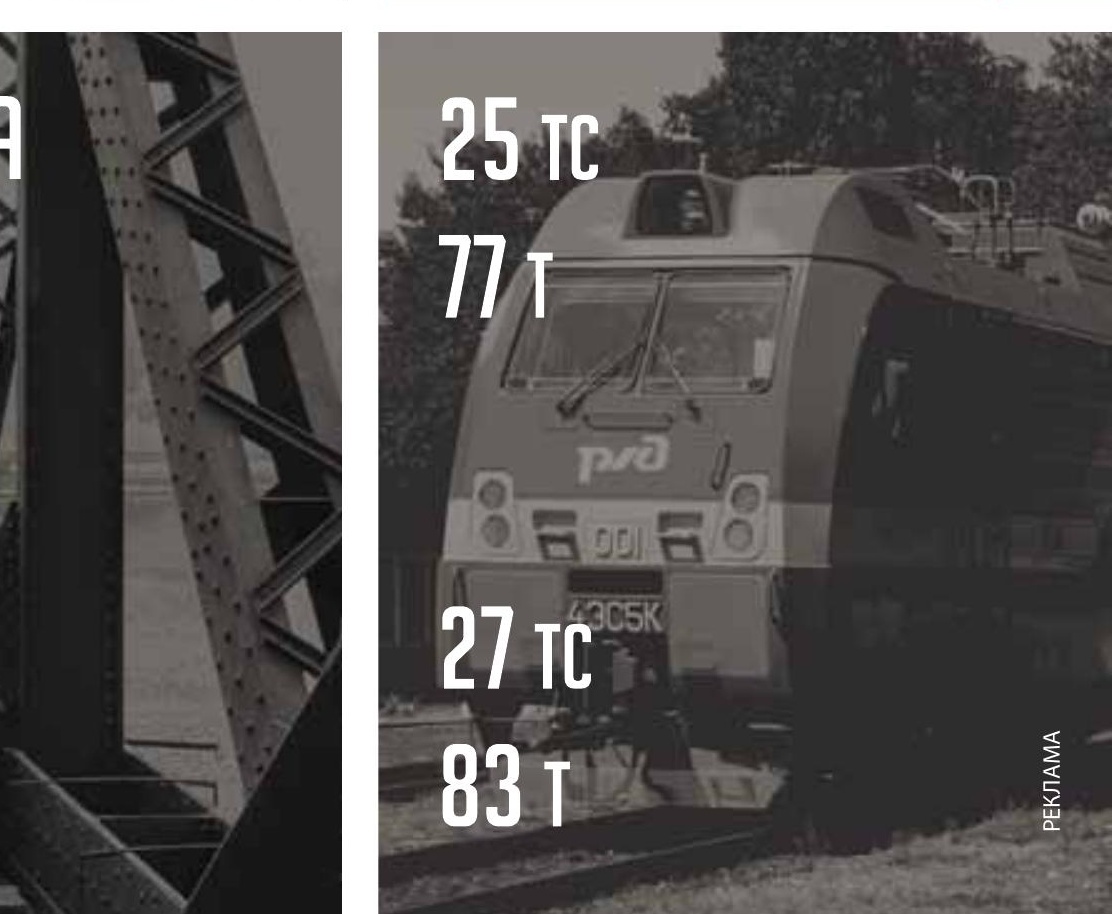


\section{Цепи и соединительные звенья для горных работ}
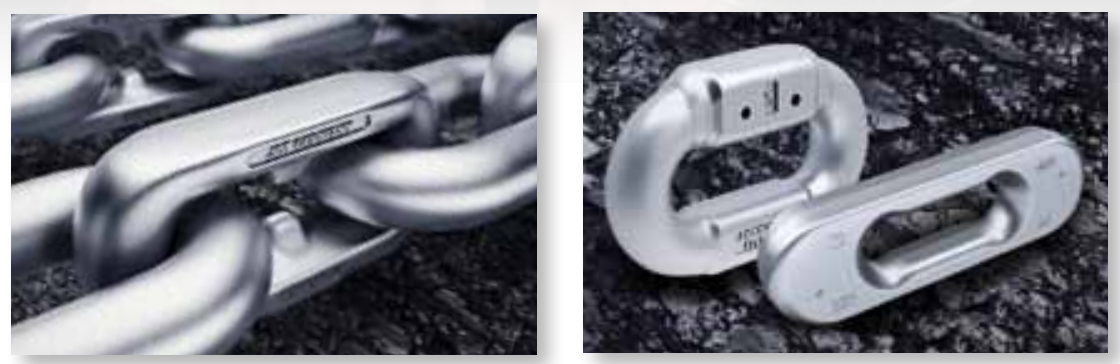

Цепи и соединительные звенья от компании JDT - наиболее известные и часто применяемые продукты в горной промышленности. Благодаря высококачественному материалу ХO (нем. НО), они обладают повышенной прочностью, устойчивостью кизносу и коррозии, длительным срокомслужбы, а также универсальностью применения и легкостью сборки и разборки.

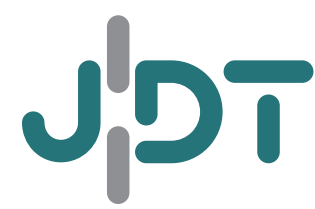




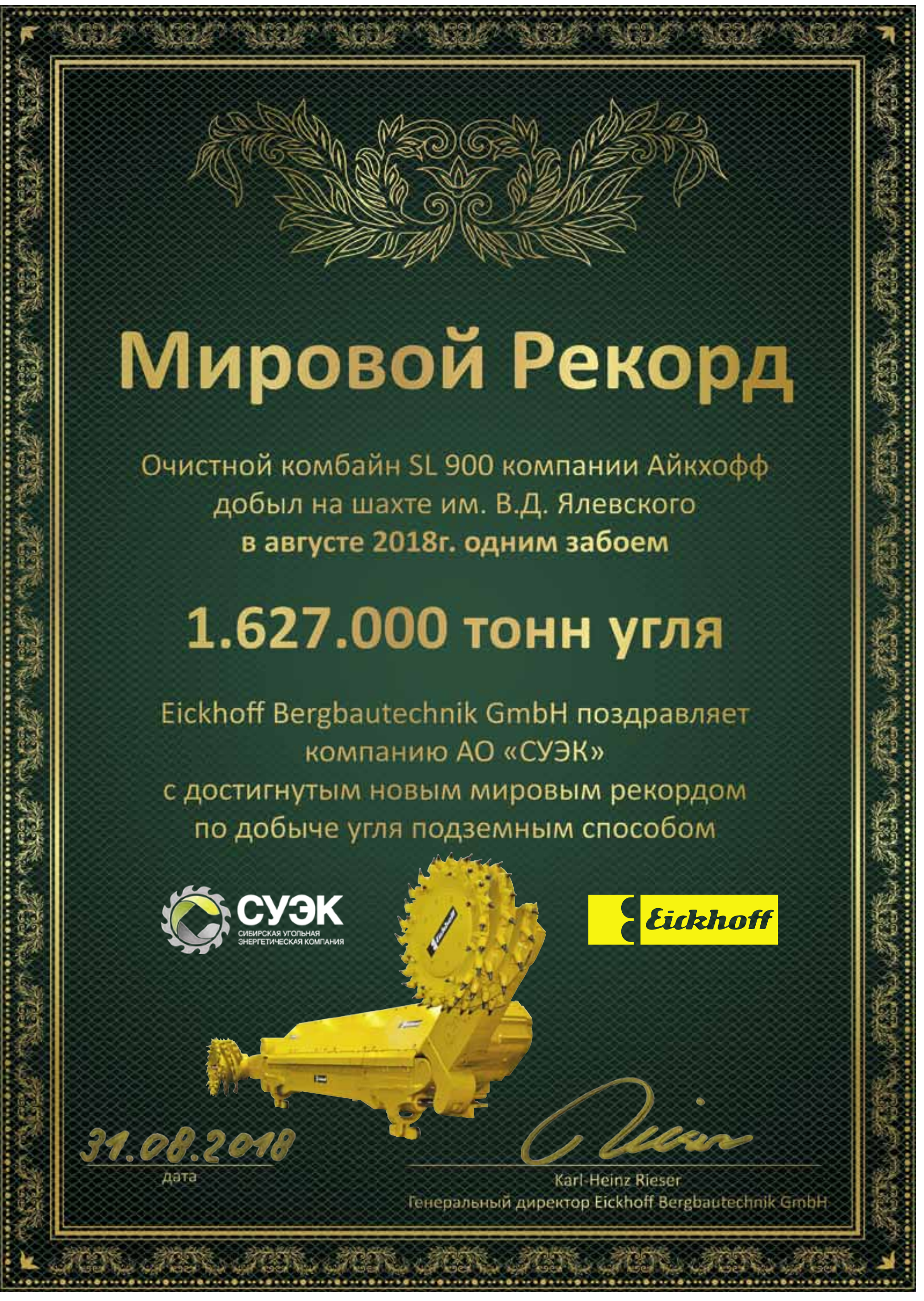


Главный редактор

ЯНОВСКИЙ А.Б.

Заместитель министра энергетики

Российской Федерачии,

доктор экон. наук

\section{Зам. главного редактора}

ТАРАЗАНОВ И.Г.

Генеральный директор

ООО «Редакция журнала «Уголь»,

горный инженер, чл.-корр. РАЭ

\section{РЕДАКЦИОННАЯ КОЛЛЕГИЯ}

AРТЕМЬEВ В.Б., доктор теХн. наук

ВЕРЖАНСКИЙ А.П.,

доктор техн. наук, профессор

ГАЛКИН В.А., Әоктор техн. наук, профессор

ЗАЙДЕНВАРГ В.Е.,

доктор техн. наук, профессор

ЗАХАРОВ В.Н., ЧЛ.-КОрр. РАН,

Әоктор техн. Наук, профессор

КОВАЛЬЧУК А.Б.,

доктор техн. наук, профессор

ЛИТВИНЕНКО В.С.,

доктор техн. наук, профессор

МАЛЫШЕВ Ю.Н., академИК РАН,

доктор техн. наук, профессор

МОХНАЧУК И.И., КаНӘ. эКОН. НаУК

МОЧАЛЬНИКОВ С.В., Канд. эКОН. Наук

ПЕТРОВ И.В., доктор эКон. наук, профессор

попов В.Н., доктор экон. наук, профессор

ПОТАПОВ В.П.,

доктор техн. наук, профессор

ПучкОВ л.А., чл.-корр. РАН,

доктор техн. наук, профессор

РОЖков А.А., доктор экон. наук, профессор

РЫБАК Л.В., доктор экон. наук, профессор

СКРЫЛЬ А.И., горный инженер

СУСлОВ В.И., чл.-корр. РАН, доктор экон.

наук, профессор

ЩАДОВ В.М., доктор техн. наук, профессор ЩУКИН В.К., доктор экон. наук

ЯКОВЛЕВ Д.В., доктор техн. наук, профессор

\section{Иностранные члены редколлегии}

Проф. Гюнтер АПЕЛЬ,

доктор техн. наук, Германия

Проф. Карстен ДРЕБЕНШТЕДТ,

доктор техн. наук, Германия

Проф. Юзеф дУБИНьСКИ,

доктор техн. наук, чл.-корр. Польской

академии наук, Польша

Сергей НИКИШИЧЕВ, комп. лицо FIMMM

канд. экон. наук, Великобритания, Россия,

страны СНГ

Проф. Любен ТОТЕВ,

доктор наук, Болгария

\section{ЕЖЕМЕСЯЧНЫЙ \\ НАУЧНО-ТЕХНИЧЕСКИЙ И ПРОИЗВОДСТВЕННО-ЭКОНОМИЧЕСКИЙ ЖУРНАЛ}

Основан в октябре 1925 года

\section{УЧРЕДИТЕЛИ}

МИНИСТЕРСТВО ЭНЕРГЕТИКИ

РОССИЙСКОЙ ФЕДЕРАЦИИ

РЕДАКЦИЯ ЖУРНАЛА «УГОЛЬ»

ОКТЯБРЬ

$10-2018 / 1111 /$

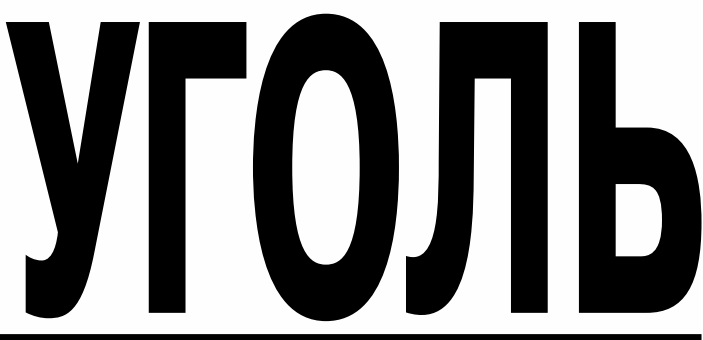

СОДЕРЖАНИЕ

\section{PEГИОНЫ}

$\mathrm{AO}$ «СУЭК»

Бригада Евгения Косьмина шахты имени В.Д. Ялевского А0 «СУЭК-Кузбасс»

установила мировой рекорд добычи угля

$\mathrm{AO}$ «СУЭК»

Информационные сообщения

\section{ОТКРЫТЫЕ РАБОТЫ}

Бурцев С.В., Левченко Я.В., Таланин В.В., Ворошилин К.С.

Безвзрывные технологии подготовки скальных горных пород

к перемещению конвейерным транспортом

\section{TPAHCПOPT}

Трухнов Л.И., Насковец А.М.

Новое семейство карьерных самосвалов БЕЛАЗ с электромеханической трансмиссией

грузоподъемностью 180 тонн

\section{НОВОСТИ ТЕХНИКИ}

Глинина 0.И.

XXV Юбилейная международная специализированная выставка «Уголь России и Майнинг».

IX Международная специализированная выставка «0храна, безопасность труда

и жизнедеятельности». IV Международная специализированная выставка «Недра России»: итоги, события, факты

\section{ГОРНЫЕ МАШИНЬ}

Малафеев С.И., Серебренников Н.А.

Повышение энергетической эффективности карьерных экскаваторов

на основе модернизации электрооборудования и систем управления

\section{БЕЗОПАСНОСТЬ}

Колесниченко И.Е., Артемьев В.Б., Колесниченко Е.А.

Обоснование способа электромагнитного излучения при инициировании

и распространении взрыва метана и угольной пыли в шахтной атмосфере

Ютяев Е.П., Портола В.А., Мешков А.А., Харитонов И.Л., Жданов А.Н.

Развитие процесса самонагревания в скоплениях угля под действием молекулярной диффузии кислорода

\section{АНАЛИТИЧЕСКИЙ ОБЗОР}

Таразанов И.Г.

Итоги работы угольной промышленности России за январь-июнь 2018 года 47

\section{ЭКОНОМИКА}

Попов В.Н., Грибин Ю.Г., Гаркавенко А.Н., Рожков А.А., Мельникова А.С.

Повышение производительности, качества и эффективности труда -

основа экономичности и конкурентоспособности угледобывающих предприятий

ОРГАНИЗАЦИЯ ПРОИЗВОДСТВА

Копылов К.Н., Кубрин С.С., Решетняк С.Н.

Актуальность повышения уровня энергоэффективности и безопасности выемочного участка угольной шахты 
ООО «РЕДАКЦИЯ ЖУРНАЛА «УГОЛЬ»

119049, г. Москва,

Ленинский проспект, д. 2А, офис 819

Тел.: +7 (499) 237-22-23

E-mail:ugol1925@mail.ru

E-mail: ugol@land.ru

Генеральный директор

Игорь ТАРАЗАНОВ

Ведущий редактор

Ольга ГЛИНИНА

Научный редактор

Ирина КОЛОБОВА

Менеджер

Ирина ТАРАЗАНОВА

Ведущий специалист

Валентина ВОЛКОВА

ЖУРНАЛ ЗАРЕГИСТРИРОВАН

Федеральной службой по надзору

в сфере связи и массовых коммуникаций.

Свидетельство о регистрации

средства массовой информации

ПИ № ФС77-34734 от 25.12.2008

ЖУРНАЛ ВКЛЮЧЕН

В Перечень ВАК Минобразования и науки РФ

(в международные реферативные базы

данных и системы цитирования) -

по техническим и экономическим наукам

Двухлетний импакт-фактор РИНЦ - 0,647

(без самоцитирования - 0,528)

Пятилетний импакт-фактор РИНЦ - 0,385

(без самоцитирования - 0,313)

ЖУРНАЛ ПРЕДСТАВЛЕН

В Интернете на вэб-сайте

\section{www.ugolinfo.ru www.ugol.info}

и на отраслевом портале «РОССИЙСКИЙ УГОЛЬ»

\section{wWw.rosugol.ru}

\section{НАД НОМЕРОМ РАБОТАЛИ:}

Ведущий редактор О.И. ГЛИНИНА

Научный редактор И.М. КОЛОБОВА

Корректор В.В. ЛАСТОВ

Компьютерная верстка Н.И. БРАНДЕЛИС

Подиисано в печать 02.10.2018.

Формат 60х90 1/8.

Бумага мелованная. Печать офсетная.

Усл. печ. л. 13,0 + обложка.

Тираж 5100 экз.

Тираж эл. версии 1600 экз.

Общий тираж 6700 экз.

Отпечатано:

ООО «РОЛИКС»

117218, г. Москва, ул. Кржижановского, 31

Тел.: (495) 661-46-22;

www.roliksprint.ru

Заказ № 56357

Журнал в App Store $n$ Google Play

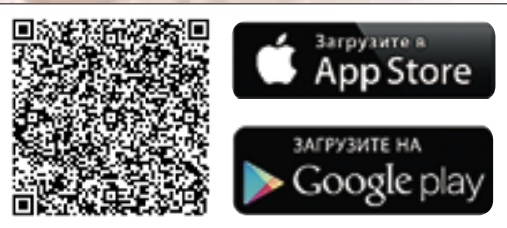

๑ ЖУРНАЛ «УГОЛЬ», 2018
Чернов А.И., Зиновьев А.В., Кравчук И.Л., Смолин А.В.

Совершенствование организации и контроля рабочих процессов на угольном разрезе для снижения производственного риска

\section{PECУPCЫ}

Абдрахимов В.3.

Снижение экологического ущерба экосистемам за счет использования межсланцевой глины и золошлакового материала в производстве легковесного кирпича и пористого заполнителя

\section{ХРОНИКА}

Хроника. События. Факты. Новости

Жунда С.В., Степашкин А.Л., Довженок А.С.

Повышение ценности руководимого - главная задача руководителя

\section{экология}

Лавриненко А.Т., Моршнев Е.А.

Инновационные методы рекультивации отвалов угледобывающих предприятий в криоаридных условиях Средней Сибири

Трушина Г.С.

Влияние угольной промышленности Кузбасса на экологическую

и продовольственную безопасность региона

\section{ЗА РУБЕЖОМ}

Зеньков И.В.

Инженерные решения по предотвращению пожаров на угольных разрезах Австралии 102

Книжная новинка 103

Список реклам:

Восток1520 1-я обл. J.D. Theile GmbH \& Co. KG ЕГГФ НПФ Гранч Eickhoff Bergbautechnik GmbH 2 БелТраноЛогистик 18 FLEXCO EUROPE GmbH

$\begin{array}{lc}\text { Hauhinco Maschinenfabrik GmbH } & 29 \\ \text { НПП Завод МДУ } & 29 \\ \text { Объединенная Энергия } & 35 \\ \text { МУФТА ПРО } & 71 \\ \text { Выставка MiningWorld Russia } & 84 \\ \text { Выставка МАЙНИНГ МЕТАЛЛ } & 93\end{array}$
23

$* * *$

Журнал «Уголь» входит

в международные реферативные базы данных и систем цитирования

\section{SCOPUS, GeoRef, Chemical Abstracts}

\section{Журнал «Уголь» является партнером CROSSREF}

Редакция журнала «Уголь» является членом Международной ассоциации по связям издателей / Publishers International Linking Association, Inc. (PILA).

Всем научным статьям журнала присваиваются Digital Object Identifier (DOI).

\section{Журнал «Уголь» является партнером EBSCO}

Редакция журнала «Уголь» имеет соглашение с компанией EBSCO Publishing, Inc. (США). Все публикации журнала «Уголь» с 2016 г. входят в базуданных компании EBSCO Publishing (www.ebsco.com), предоставляющей свою базу данных для академических библиотек по всему миру. EBSCO имеет партнерские отношения с библиотеками на протяжении уже более 70 лет, обеспечивая содержание исследований качества, мощные технологии поиска и интуитивные платформы доставки.

\section{Журнал «Уголь» представлен в «КиберЛенинке»}

Электронная научная библиотека «КиберЛенинка» (CYBERLENINKA) входит в mon-10 мировых электронных хранилищ научных публикачий и построена на парадигме открытой науки (Open Science), основными задачами которой являются популяризация науки и научной деятельности, общественный контроль качества научных публикаций, развитие междисциплинарных исследований и повышение цитируемости российской науки. Это третья в мире электронная библиотека по степени видимости материалов в Google Scholar.

\section{Подписные индексы:}

- Каталог Роспечати «Газеты. Журналы» - 71000, 71736, 73422

- Объединенный каталог «Пресса России» - 87717, 87776, $\mathbf{9 8 7 7 1 7}$

- Каталог «Российской прессы» - 11538

- Каталог «Урал-Пресс» - 71000; 007097; 009901 
UGOL' / RUSSIAN COAL JOURNAL UGOL' JOURNAL EDITORIAL BOARD

Chief Editor

YANOVSKY A.B., Dr. (Economic), Ph.D. (Engineering), Deputy Minister of Energy of the Russian Federation, Moscow, 107996, Russian Federation

Deputy Chief Editor

TARAZANOV I.G., Mining Engineer, Moscow,

119049, Russian Federation

Members of the editorial council:

ARTEMIEV V.B., Dr. (Engineering),

Moscow, 115054, Russian Federation

VERZHANSKY A.P., Dr. (Engineering), Prof.,

Moscow, 125009, Russian Federation

GALKIN V.A., Dr. (Engineering), Prof.,

Chelyabinsk, 454048, Russian Federation

ZAIDENVARG V.E., Dr. (Engineering), Prof.,

Moscow, 119019, Russian Federation

ZAKHAROV V.N., Dr. (Engineering), Prof.,

Corresp. Member of the RAS,

Moscow, 111020, Russian Federation

KOVALCHUK A.B., Dr. (Engineering), Prof.,

Moscow, 119019, Russian Federation

LITVINENKO V.S., Dr. (Engineering), Prof.,

Saint Petersburg, 199106, Russian Federation

MALYSHEV Yu.N., Dr. (Engineering), Prof.,

Acad. of the RAS, Moscow, 125009, Russian

Federation

MOKHNACHUK I.I., Ph.D. (Economic),

Moscow, 109004, Russian Federation

MOCHALNIKOV S.V., Ph.D. (Economic),

Moscow, 107996, Russian Federation

PETROV I.V., Dr. (Economic), Prof.,

Moscow, 119071, Russian Federation

POPOV V.N., Dr. (Economic), Prof.,

Moscow, 119071, Russian Federation

POTAPOV V.P., Dr. (Engineering), Prof.,

Kemerovo, 650025, Russian Federation

PUCHKOV L.A., Dr. (Engineering), Prof.,

Corresp. Member of the RAS, Moscow, 119049,

Russian Federation

ROZHKOV A.A., Dr. (Economic), Prof.,

Moscow, 119071, Russian Federation

RYBAK L.V., Dr. (Economic), Prof.,

Moscow, 119034, Russian Federation

SKRYL' A.I., Mining Engineer,

Moscow, 119049, Russian Federation

SUSLOV V.I., Dr. (Economic), Prof., Corresp.

Member of the RAS, Novosibirsk, 630090, Russian

Federation

SHCHADOV V.M., Dr. (Engineering), Prof.,

Moscow, 119034, Russian Federation

SHCHUKIN V.K., Dr. (Economic),

Ekibastuz, 141209, Republic of Kazakhstan

YAKOVLEV D.V., Dr. (Engineering), Prof.,

Saint Petersburg, 199106, Russian Federation

Foreign members of the editorial council:

Prof. Guenther APEL, Dr.-Ing.,

Essen, 45307, Germany

Prof. Carsten DREBENSTEDT, Dr. (Engineering),

Freiberg, 09596, Germany

Prof. Jozef DUBINSKI, Dr. (Engineering), Corresp.

Member PAS, Katowice, 40-166, Poland

Sergey NIKISHICHEV, FIMMM, Ph.D. (Economic),

Moscow, 125047, Russian Federation

Prof. Luben TOTEV, Dr., Sofia, 1700, Bulgaria

Ugol' Journal Edition LLC

Leninsky Prospekt, 2A, office 819

Moscow, 119049, Russian Federation

Tel.: +7 (499) 237-2223

E-mail: ugol1925@mail.ru

www.ugolinfo.ru
MONTHLY JOURNAL, THAT DEALS WITH SCIENTIFIC, TECHNICAL, INDUSTRIAL AND ECONOMIC TOPICS

Established in October 1925

FOUNDERS

MINISTRY OF ENERGY

THE RUSSIAN FEDERATION,

UGOL' JOURNAL EDITION LLC

OCTOBER

$10^{\prime} 2018$

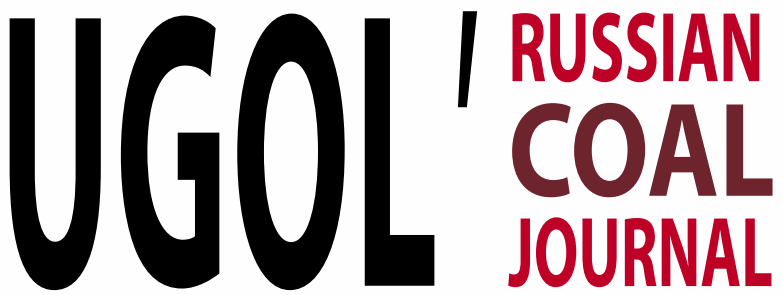

CONTENT

REGIONS

"SUEK" JSC

Evgeniy Kosmin's crew of V.D. Yalevsky's mine has set a underground coal-mining World record 1

"SUEK"JSC

Information messages

6

SURFACE MINING

Burtsev S.V., Levchenko Ya.V., Talanin V.V., Voroshilin K.S.

Blastless technologies for rock mass conditioning for conveyor transportation

8

TRANSPORT

Truhnov L.I., Naskovets A.M.

New family of the BELAZ dump trucks with electromechanical transmission with a loading capacity of 180 tons 19

TECHNICAL NEWS

Glinina 0.I.

XXV Anniversary International Trade Fair "Ugol Rossii \& Mining": Summary, Events and Facts

22

COAL MINING EQUIPMENT

Malafeev S.I., Serebrennikov N.A.

Increasing energy efficiency of mining excavators through upgrade of electrical equipment and control systems

30

SAFETY

Kolesnichenko I.E., Artemiev V.B., Kolesnichenko E.A.

Substantiation of electromagnetic radiation principle during initiation and propagation

of methane or coal dust explosion in the mine atmosphere

Yutyaev E.P., Portola V.A., Meshkov A.A., Kharitonov I.L., Zhdanov A.N.

Development of self-heating process in coal stocks under molecular diffusion of oxygen

ANALYTICAL REVIEW

Tarazanov I.G.

Russia's coal industry performance for January - June, 2018

47

ECONOMIC OF MINING

Popov V.N., Gribin Yu.G., Garkavenko A.N., Rozhkov A.A., Melnikova A.S.

Improvement of labor efficiency, quality and performance is the basic principle

of coal mining enterprises cost efficiency and competitiveness

PRODUCTION SETUP

Kopylov K.N., Kubrin S.S., Reshetnyak S.N.

The importance of improving energy efficiency and safety of coal mine extraction area

Chernov A.I., Zinoviev A.V., Kravchuk I.L., Smolin A.V.

Improving the organization and control of work processes on the coal mine to reduce occupational hazards 72

RESOURCES

Abdrakhimov V.Z.

Environmental system damage mitigation due to interschistic clay and bottom-ash material application

in lightweight brick and porous aggregate production

77

CHRONICLE

The chronicle. Events. Facts. News

CURRENT ISSUES

Zhunda S.V., Stepashkin A.L., Dovgenok A.S.

Enhancing the value of a supervised employee is the key task of a manager

ECOLOGY

Lavrinenko A.T., Morshnev E.A.

Innovative methods of re-cultivation of dumps of coal-mining enterprises

in cryoarid conditions of Middle Siberia

94

Trushina G.S.

The influence of the Kuzbass coal industry on the ecological and food security of the region 98

ABROAD

Zenkov I.V.

Engineering solutions for prevention of fires in Australian coal mines 102 


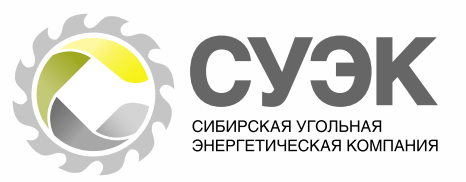

\title{
Шахта «Комсомолец» первой в СУЭК выполнила годовой план по подготовительным работам
}

\author{
Шахта «Комсомолец» АО «СУЭК-Кузбасс» первой в Сибирской угольной энер- \\ гетической компании 20 сентября 2018 г. досрочно выполнила годовой план по \\ подготовке очистного фронта. \\ С начала 2018 года проходчиками предприятия пройдено 8110 м горных вы- \\ работок.
}

В общий успех свой вклад внесли все четыре маршевые бригады, работающие на отечественных комбайнах КП-21. Больше всего пройдено коллективом Сергея Подрезова - 2700 м. Это лучший показатель предприятия и в целом по компании. Опережение плана составляет километр горных выработок. Бригады Дмитрия Котика, Ивана Пономарева и Сергея Глазычева подготовили с начала года соответственно 2 000, 1750 и 1668 м. Общее перевыполнение плана по предприятию - почти 2 км горных выработок.

Успешная работа проходчиков способствовала своевременному вводу в эксплуатацию первого очистного забоя на новом пласту «Толмачевский». Лава № 1846 с вынимаемой мощностью пласта 2,9 м и запасами угля 2,7 млн т оснащена 176 секциями крепи Глиник-15/32 (Польша), комбайном SL-300, лавным конвейером SH PF-4/1032 (Германия). Для транспортировки угля с нового пласта введен в строй дополнительный конвейер с шириной ленточного полотна 1200 мм. Общий объем затрат на запуск лавы составил более 75 млн руб.

Для предприятия, отметившего в этом году свое 85-летие, начало эксплуатации пласта «Толмачевский» означает новый период ее истории. Шахта выходит на стабильный годовой уровень добычи 2,5 млн т угля. В предыдущей истории такой уровень производительности достигался только один раз. Сегодня запасы угля на предприятии превышают 60 млн т. При шахте действует прошедшая глубокую модернизацию обогатительная фабрика, способная перерабатывать до 3 млн т горной массы в год.

Для развития горных работ на шахте «Комсомолец» руководством АО «СУЭК» принято решение о поставке на предприятие в следующем году двух комбайнов фронтального действия MB 670-1 SANDVIK MINING.

Наша справка.

AO «Сибирская угольная энергетическая компания» (СУЭК) - одна из ведущих угледобывающих компаний мира, крупнейший в России производитель угля, крупнейший поставщик угля на внутренний рынок и на экспорт, один из ведущих производителей тепла и электроэнергии в Сибири. Добывающие, перерабатывающие, энергетические, транспортные и сервисные предприятия СУЭК расположены в 11 регионах России. На предприятиях СУЭК работают более 66000 человек. Основной акционерАндрей Мельниченко.

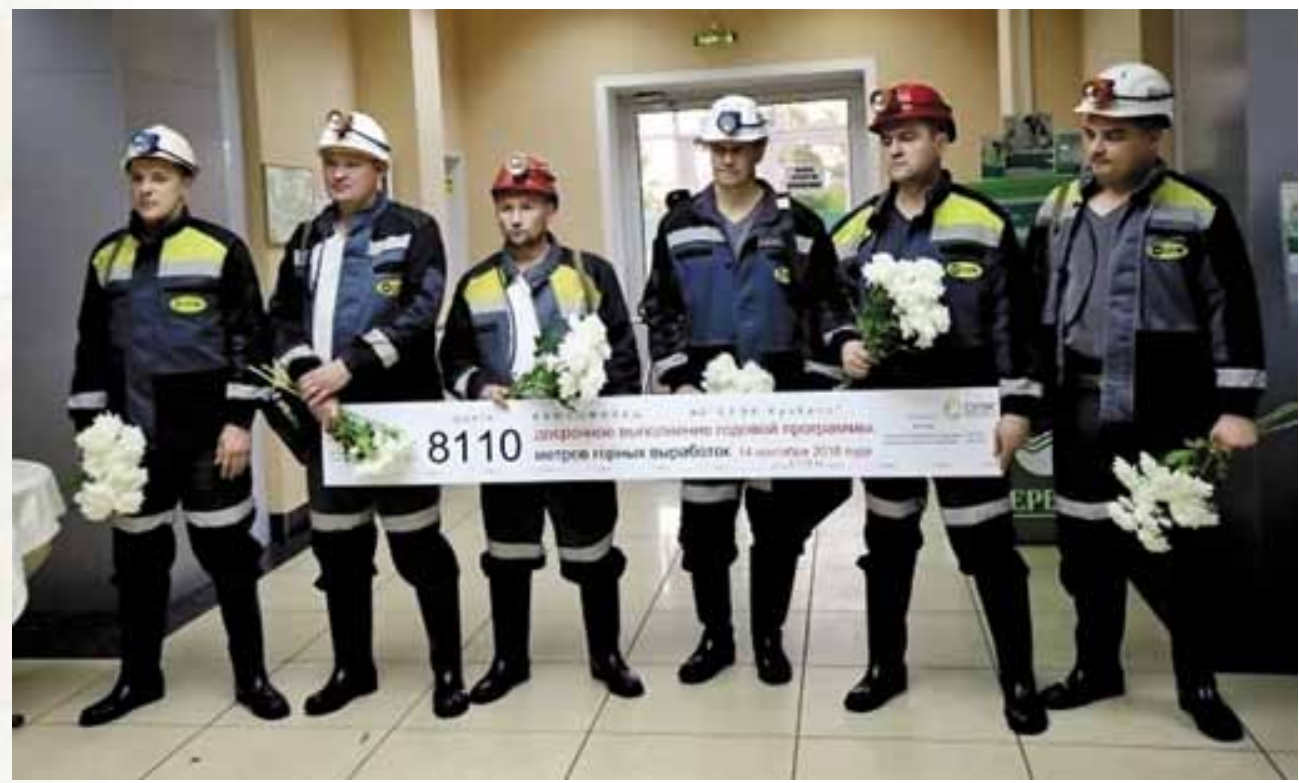




\section{Экскаваторная бригада Виталия Арестова АО «СУЭК-Кузбасс» установила мировой рекорд по отгрузке горной массы}

Экскаваторная бригада Виталия Арестова разреза "Камышанский» АО «СУЭК-Кузбасс» по итогам августа 2018 г. установила мировой рекорд по отгрузке горной массы экскаватором Komatsu PC-1250-7, серийный № 20830.

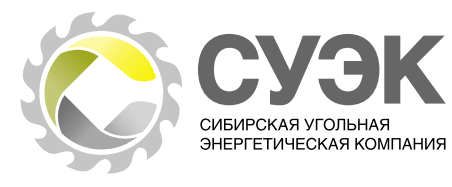

лифицированных машинистов являются неотъемлемыми составляющими успеха в достижении столь высоких результатов».

Как отмечают сами открытчики, экскаватор PC-1250-7 обладает рядом неоспоримых преимуществ. У него самая высо-

За месяц коллективом погружено в автотранспорт 538,6 куб. м горной массы. Достижение наивысшей производительности для данного класса машин официально подтверждено руководителями ООО «Комацу СНГ».

В поздравлении коллективу разрезоуправления от производителей подчеркнуто: «Высококачественная, надежная и грамотно подобранная техника под конкретные горно-геологические условия и задачи предприятия, спланированная, рациональная организация производства, слаженная и профессиональная работа высококвакая вместимость ковша в своем классе - до 6,5 куб. м, высокая гидравлическая мощность двигателя способствует быстрому выполнению рабочего цикла по резанию грунта. Но очень многое зависит от слаженности экскаваторной бригады. Это не первое мировое достижение данного коллектива. В прошлом году по итогам работы в июле бригада Виталия Арестова погрузила за месяц 451,7 куб. м горной массы. Благодаря отличным производственным показателям в копилке бригады уже есть два наградных легковых автомобиля от компании «СУЭК-Кузбасс».

\section{В Бородино состоялась рабочая встреча участников Сибирской школы социального предпринимательства}

\begin{abstract}
В Бородино состоялась рабочая встреча участников Сибирской школы сочиального предпринимательства. Маситабный проект по развитию сочиального предпринимательства на шахтерских территориях
\end{abstract} реализует Фонд «СУЭК - РЕГИОНАМ». Его основная задача - поддержка инициативных граждан, создание новых рабочих мест в моногородах либо населенных пунктах с ограниченной емкостью рынка труда, расширение спектра и повышение качества социальных услуг.

«Студентами» школы становятся начинающие предприниматели, работники бюджетной сферы - руководители и сотрудники школ, детских садов, педагоги дополнительного образования. По мнению экспертов Школы социального предпринимательства, именно сферы образования и бытовых услуг являются наиболее перспективными с точки зрения развития такого вида бизнеса, а занятые в них сотрудники - достаточно мобильными и открытыми к новым знаниям и идеям.

Действительно, несмотря на то, что в Бородино Школа социального предпринимательства начала работать всего полгода назад, ее участники уже представили экспертам десятки идей - от открытия послешкольной площадки для первоклашек в Центре технического творчества до создания рекреационной зоны в местном лагере

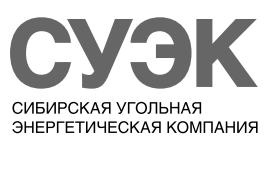

«Шахтер». В своих докладах они озвучили идеи новых платных социальных услуг, рассказали о том, какие шаги по их внедрению уже сделаны.

По словам Алексея Перепелкина, заместителя программного директора некоммерческой организации «Новые технологии развития», выступающей оператором Фонда «СУЭК - РЕГИОНАМ» по реализации программы развития социального предпринимательства, подобный формат обучения, включающий не только лекции и практикумы, но и открытое обсуждение проектов, помогает учащимся увидеть пробелы в своих разработках, найти дополнительные инструменты для решения тех задач, которые они ставят перед собой.

В октябре 2018 г. среди слушателей Сибирской школы социального предпринимательства пройдет конкурс, на котором будут подведены итоги учебного года. Лучшие проекты получат дополнительное финансирование от Фонда «СУЭК - РЕГИОНАМ».

Добавим, Бородино стало второй территорией в Красноярском крае, где Фонд реализует программу развития социального предпринимательства, пилотным же регионом является г. Шарыпово - за 5 лет действия программы здесь не только запущены, но и успешно функционируют более десяти малых предприятий и организаций, созданных выпускниками Школы социального предпринимательства при поддержке СУЭК. 


\title{
Безвзрывные технологии
}

\section{подготовки скальных горных пород к перемещению конвейерным транспортом}

\author{
DOI: http://dx.doi.org/10.18796/0041-5790-2018-10-8-17
}
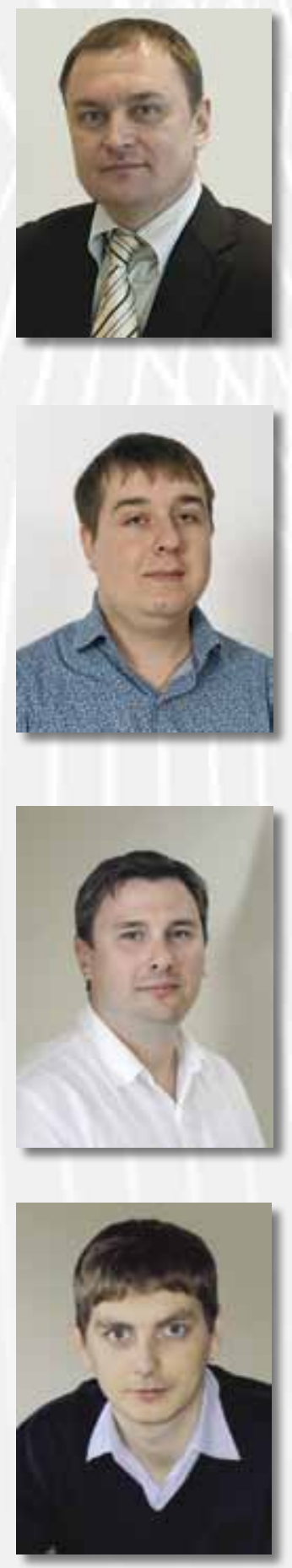

\section{БУРЦЕВ}

\section{Сергей Викторович}

Канд. экон. наук,

первый заместитель генерального директора технический директор АО ХК «СДС-Уголь», 650066, г. Кемерово, Россия, e-mail: s.burtsev@sds-ugol.ru

\section{ЛЕВЧЕНКО}

Ярослав Викторович

Канд. техн. наук, старший преподаватель Горного института НИТУ «МИСИС», 119049, г. Москва, Россия, e-mail: levchenko.mggu@mail.ru

\section{ТАЛАНИН}

\section{Владимир Вадимович}

Канд. техн. наук,

дочент Горного института НИТУ «МИСИС», 119049, г. Москва, Россия

\section{ВОРОшИлИн}

Константин Сергеевич

Старший преподаватель

Горного института

НИТУ «МИСИС»,

119049, г. Москва, Россия
В статье рассмотрены основные безвзрывные технологии подготовки скальных горных пород, применение которых возможно в комплексе с конвейерным транспортом. Приведены принципы работы фрезерных комбайнов и технологические схемы их эксплуатации. Выполнено сопоставление энергоемкости и фракционного состава при безвзрывной и взрывной отработке пород. Указаны лимитирующие факторы физико-механических свойств пород, пригодных для отработки фрезерными рабочими органами горных комбайнов. С учетом предварительного взрывания массива на «встряхивание» сделан обзор использования компактных роторных экскаваторов. Применительно к слоистым массивам рассмотрена безвзрывная отработка посредством гидравлических экскаваторов и гидромолотов. Показаны области использования оборудования для безвзрывной отработки пород.

Ключевые слова: безвзрывная технология, конвейерный транспорт, фрезерные машины, энергоемкость, компактные роторные экскаваторы, гидромолоты, комплексы ЦПТ, фракционный состав пород, экскаваторная разборка массива.

\section{ВВЕДЕНИЕ}

В последние несколько лет на карьерах, отрабатывающих скальные породы средней крепости, все чаще находят применение безвзрывные способы подготовки массивов к выемке. Их реализация возможна на базе двух принципиально отличающихся друг от друга технологических процессов:

- резания и скола горных пород, реализуемых на базе фрезерных, роторных и струговых рабочих органов выемочных машин (непрерывный характер выемки);

- разборки массива по линиям слоистости, реализуемой посредством экскаваторов и гидромолотов различного конструктивного исполнения (цикличный характер выемки).

Вопросы влияния геологической структуры на выбор процесса безвзрывной разработки массивов горных пород, к сожалению, не находят должной оценки при выборе горных технологий, что во многих случаях приводит к неоптимальным (часто ошибочным) решениям при выборе комплексов оборудования для разработки угольных, карбонатных, гипсовых и других месторождений. 
РАЗРУШЕНИЕ ГОРНЫХ ПОРОД ФРЕЗЕРНЫМИ КОМБАЙНАМИ

Традиционные технологии производства горных работ часто не могут обеспечить выемку тонких природных прослойков полезного ископаемого и вскрышных пород, что приводит к его потерям и разубоживанию в процессе выемки. Для уменьшения влияния технологии производства горных работ на качественные показатели добытого полезного ископаемого целый ряд зарубежных и отечественных фирм ведет интенсивные работы по созданию высокопроизводительного оборудования непрерывного действия для открытых разработок, основанных на принципах резания горных пород.

На современном уровне развития горного машиностроения подготовка исходных горных пород к перемещению конвейерным транспортом может быть реализована посредством фрезерных комбайнов (Continuous Surface Miner - CSM) различных типов и специальных фрезерных рыхлителей (рис. 1).

Принцип работы данных машин основан на использовании резания и скола горных пород режущим инструментом с последующим их додрабливанием в процессе перемещения отбитого материала по шнековым (или иным) рабочим органам комбайнов.

Данный тип машин по своему технологическому предназначению представляет мобильный фрезернодробильный агрегат, обеспечивающий механическое разрушение массива горных пород с формированием гранулометрического состава материала в диапазоне фракций 0-250 мм, 0-350 мм, пригодного для перемещения конвейерным транспортом.

Принцип разрушения горного массива (резание, скол, дробление) фрезерными комбайнами имеет аналогии с одновалковыми дробилками, выпускаемыми фирмой Stamler (puc. 2).

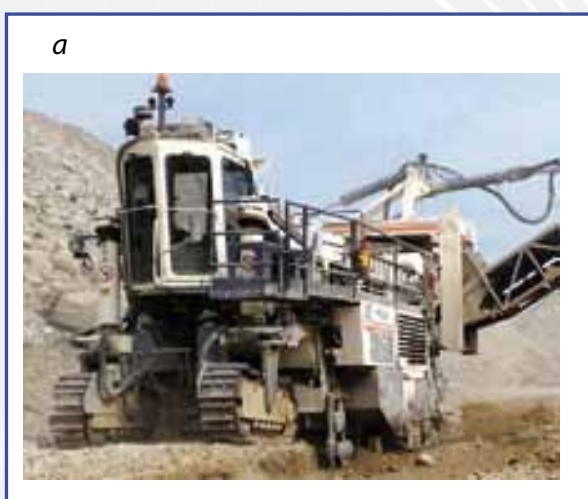

B

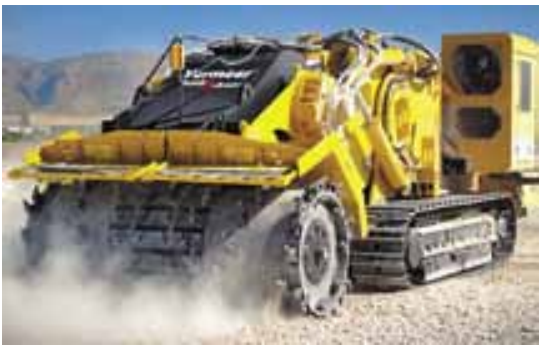

$\partial$

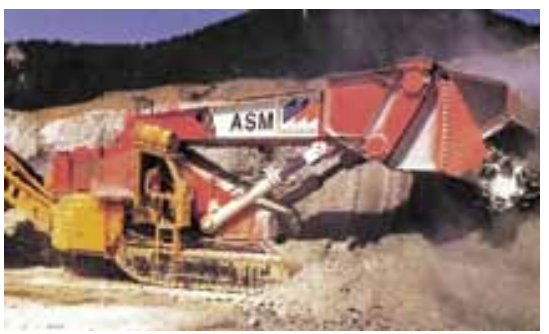

Рис. 1. Внешний вид основных типов фрезерных и стреловых комбайнов: a - шнеково-фрезерная машина 2500 SM фирмы «Wirtgen» с иенттральным расположением рабочего органа; б - комбайн MTS 250 фирмы Tenova TAKRAF с передним расположением рабочего органа; в - фрезерный рыхлитель T1255 TL фирмы Vermeer с задним расположением рабочего органа;

2 - стреловой врубово-погрузочный комбайн CME фирмы Rahco;

д-стреловой фрезерный комбайн фирмы Voest-Alpine Bergtechnik;

$e$ - двухстреловой фрезерный комбайн TB 3000 фирмы Dosсо

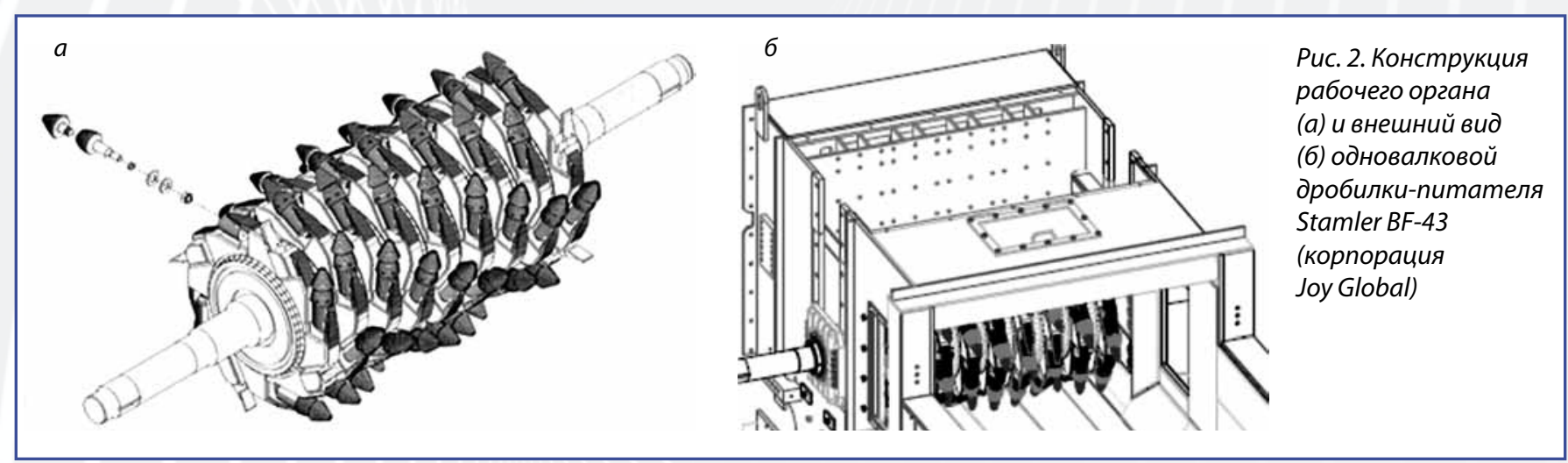

Машины с фрезерным исполнительным органом и компактные роторные экскаваторы получили наибольшее распространение на карьерах, отрабатывающих неабразивные горные породы осадочного происхождения средней крепости. Особенно благоприятно их использование там, где по различным причинам нельзя применять буровзрывные работы (охранные зоны жилой застройки, железных и автомобильных дорог, рек и т.д.). 


\section{ОСНОВНЫЕ СХЕМЫ РАБОТЫ ФРЕЗЕРНЫХ КОМБАЙНОВ}

Фрезерные комбайны могут работать по трем основным технологическим схемам:

- первая схема предусматривает непосредственную погрузку комбайном отбиваемого материала в средства транспорта;

- вторая схема предполагает работу комбайна в качестве самоходной дробильной установки с укладкой отбиваемого материала в валки с последующей погрузкой колесным погрузчиком;

- третья схема работы комбайна предусматривает его непосредственную работу в составе комплекса цикличнопоточной технологии (ЦПТ) или совместно с мобильным перегрузочным бункером.

Первая технологическая схема получила наибольшее распространение на открытых горных работах. Вторая технологическая схема нашла свое применение на ряде

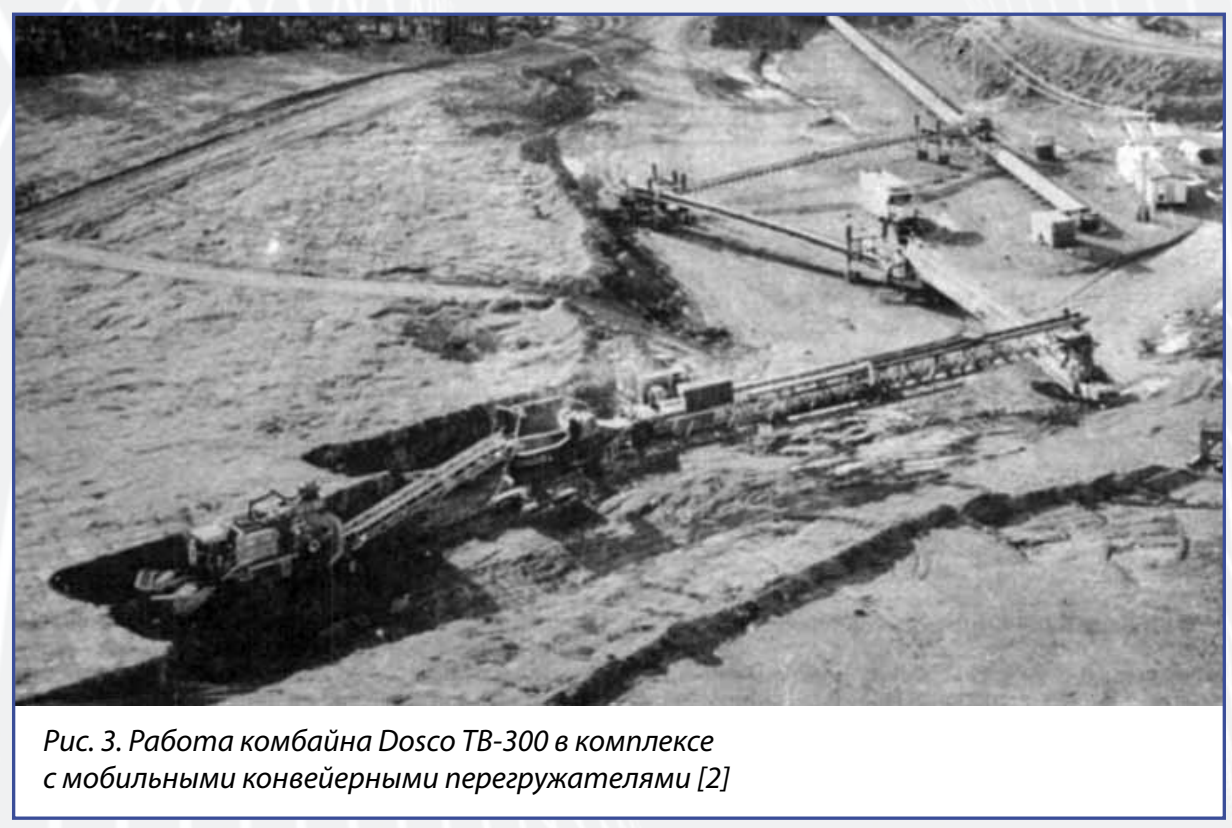

месторождений (США, Индия, Мексика и другие страны) по добыче гипса, угля, соли, железной руды. На карьере «Eagle Mine» (США) используют фрезерные комбайны без разгрузочного конвейера. Они работают как передвижные дробильные агрегаты, укладывая раздробленный материал сзади по ходу движения в валки шириной 1-1,2 м.

Далее колесным погрузчиком из уложенного в валки материала выборочно удаляется пустая порода (около 40-45\% общего объема горной массы), что обеспечивает минимальное разубоживание полезного ископаемого. Порода укладывается погрузчиком в раздельные штабели, из которых по мере необходимости материал отгружается в трейлеры с донной разгрузкой [1]. Вышесказанную схему можно считать основой для создания комплексов ЦПТ с использованием фрезерных комбайнов. При выгрузке трейлеров в бункер-питатель его последующая транспортировка на расстояния от 5 до 25 км может выполняться конвейерным транспортом, обладающим минимальными эксплуатационными издержками.

Перспективным является работа горных комбайнов по третьей технологической схеме без использования автотранспорта. Многие фирмы-изготовители фрезерных комбайнов выполняют опытноконструкторские работы по созданию мостовых конвейеров и поворотных установок, обладающих значительной маневренностью, которые должны заменить традиционные ленточные перегружатели, располагаемые между выемочной машиной и конвейером на уступе (рис. 3) [2].

Фирмой Wirtgen разработана конструкция телескопического мостового устройства, пред-

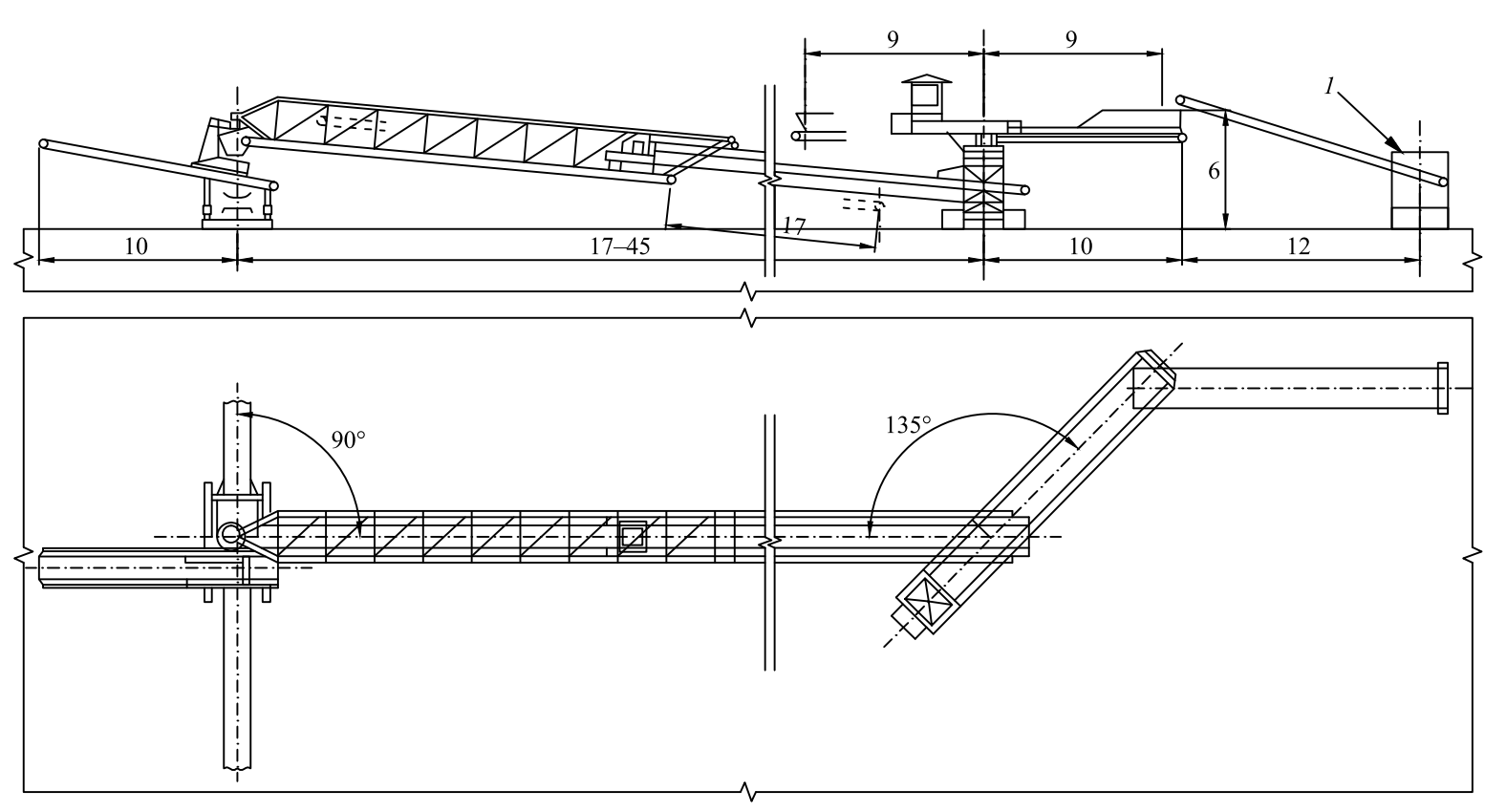

Puс. 4. Телескопическое мостовое устройство фирмы Wirtgen для работы с машиной CSM (1) 
назначенного для работы с фрезерными комбайнами (рис. 4).

Фирма Rahco создала передвижную конвейернуюустановку для работы в комплексе с горными комбайнами (рис. 5). Рама конвейера длиной 200 м смонтирована на нескольких гусеничных ходовых тележках, перемещающихся под прямым углом к ее продольной оси. Перепады высотных отметок компенсируются с помощью шарнирных опор. Гидроцилиндры, приводимые в действие автоматически, обеспечивают горизонтальное положение конвейерной ленты и предотвращают искривление рамы. Производительность этой конвейерной установки - 1000 т/ч при скорости движения ленты 4 м/с.

Фирма Voest-Alpine Bergtechnik (Sandvik) в перспективе рассматривает эксплуатацию комбайна собственного производства в комплексе с конвейерным транспортом (рис. 6).

Мобильные конвейерные системы также изготавливаются немецкой фирмой FAM. Производительность мобильной конвейерной системы, поставленной в Чили, составляет 4000 т/ч.

Открытые горные работы с применением машин с роторными колесами типа KSM (ThyssenKrupp Fördertechnik) могут основываться на способе разработки наклонными слоями. Комбайн разрабатывает породы двух уступов, которые размещены по обе стороны от передвижного уступного конвейера (рuc. 7). Погрузка на магистральный конвейер осуществляется через самоходные конвейерные модули (уступные передвижные конвейеры) [3].

Толща вмещающих пород разделяется на уступы с поперечным уклоном $8^{\circ}$. Maгистральный конвейер установлен вдоль забоя по этому уклону, уступный передвижной конвейер расположен под прямым углом к нему.

\section{ЭНЕРГОЕМКОСТЬ ПРОЦЕССА РЕЗАНИЯ ГОРНЫХ ПОРОД}

Одной из важнейших характеристик, определяющих принципиальную возможность и технологическую эффективность безвзрывной подготовки исходного материала к транспортировке конвейером, является энергоемкость процесса резания горных пород.

Принципиальное влияние на величину энергоемкости процесса резания оказывают прочность исходных пород и структура горного массива. При разработке массива по природным разностным слоям доминирующими факторами, предопределяющими энергоемкость данного процесса,

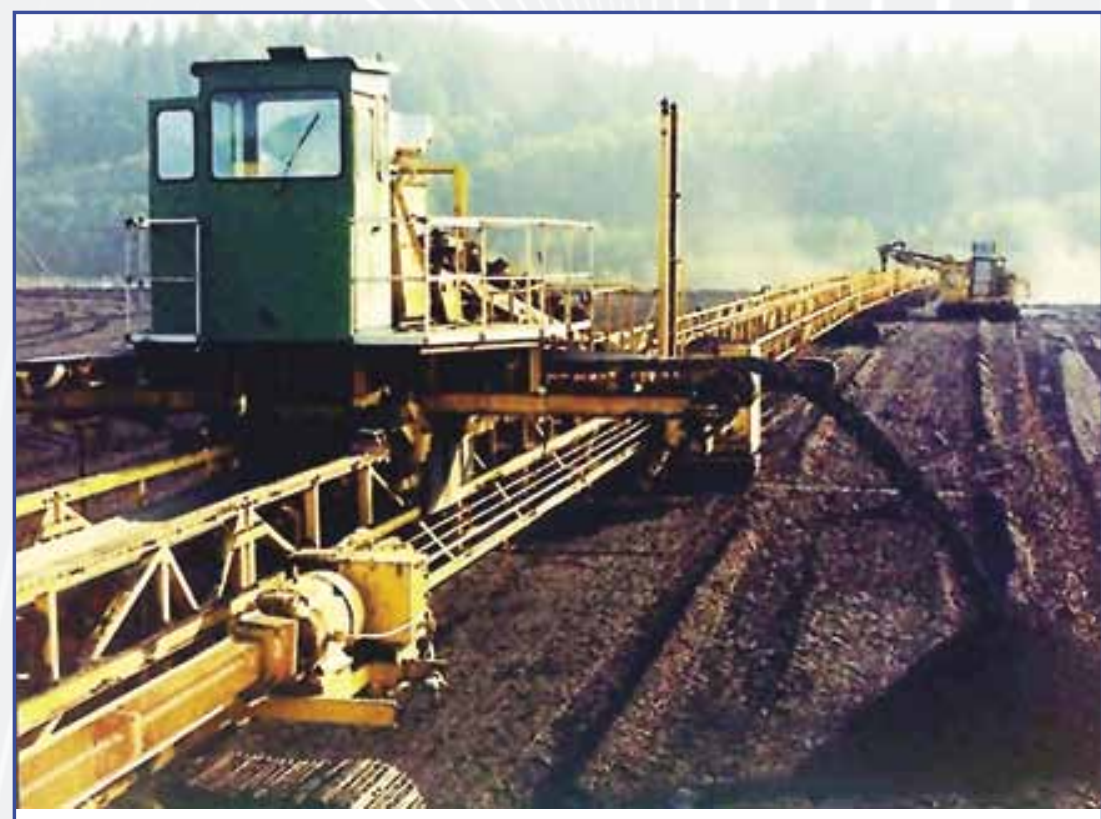

Puc. 5. Конвейерная установка фирмы Rahco (FLSmidth's) для работы в комплексе с комбайном непрерывного действия
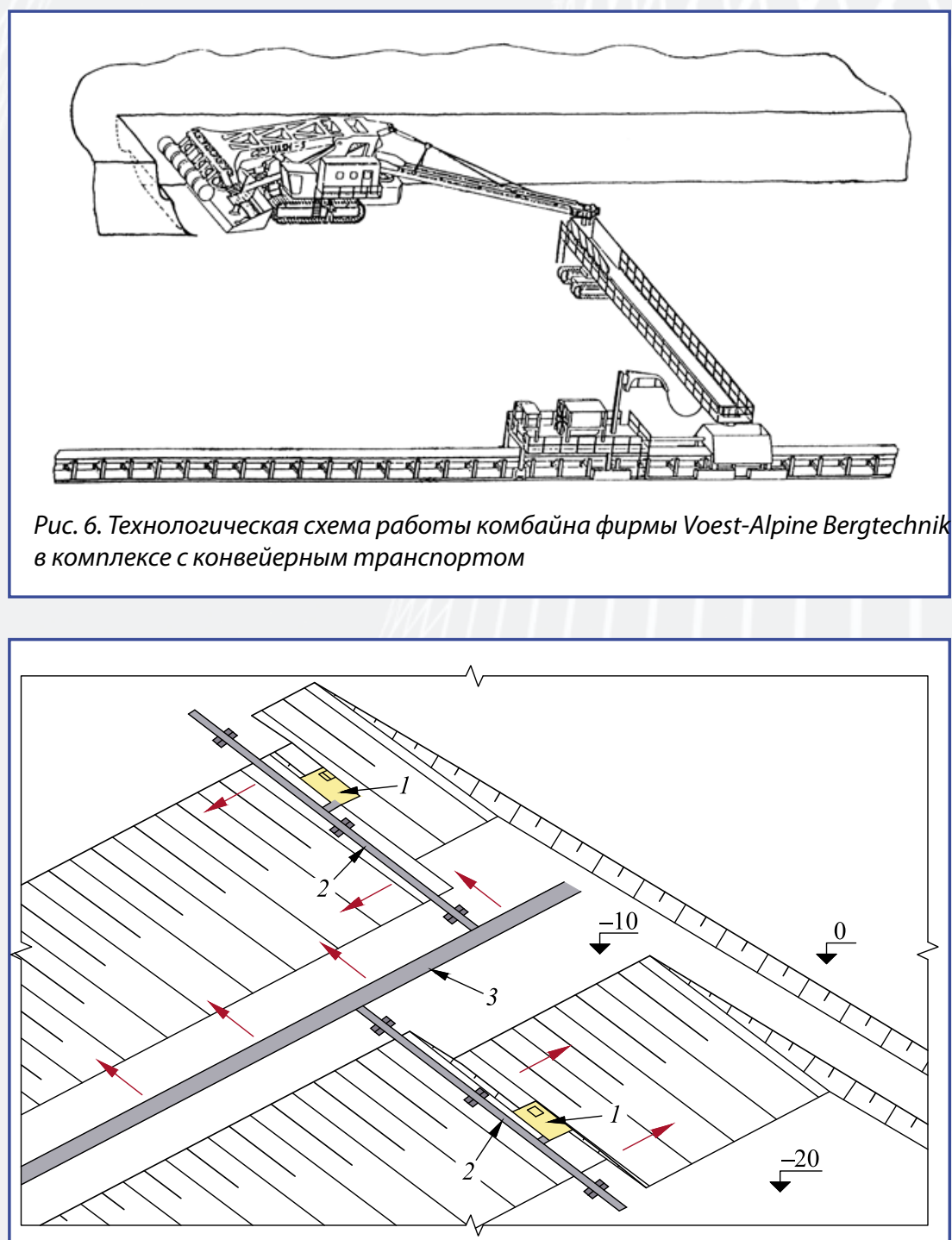

Puc. 7. Комбайны KSM с передвижными конвейерными модулями:

1 - комбайн; 2 - конвейерный модуль; 3 - магистральный конвейер; стрелками показаны направления подвигания горных работ 
Физико-механические свойства образцов известняка мячковского геологического горизонта

\begin{tabular}{|c|c|}
\hline Показатели & Значения \\
\hline Объемная масса, кг/м³ & 2370 \\
\hline Влажность, \% & $5-7$ \\
\hline Предел прочности на сжатие породы в сухом состоянии, МПа & $21,0-25,3$ \\
\hline Предел прочности на растяжение, МПа & $1,95-2,43$ \\
\hline
\end{tabular}

являются структура массива и прочность отдельных разностных слоев.

При прочности пород на одноосное сжатие более 3-5 МПа (30-50 кгс/см²) разрушение в большинстве случаев является хрупким. От массива отделяются мелкие пластины исходной породы, как правило, имеющие лещадную форму (в технической литературе эти мелкие лещадные отдельности отбитого материала называют стружкой отрыва) [4].

Испытания, проведенные специалистами МГГУ для известняков мячковского геологического горизонта, свидетельствуют, что энергоемкость процесса их резания изменяется в пределах от 1,86 до 3,31 кВт×ч/м³. Средняя величина энергоемкости разрушения мячковских известняков равна 2,58 кВт×ч/м³. Физико-механические свойства мячковских известняков приведены в табл. 1.

Использование машин CSM позволяет в потоках отбитого материала почти полностью «снять» крупную фракцию (128-300 мм), однако фракция 64-128 мм сохраняет-

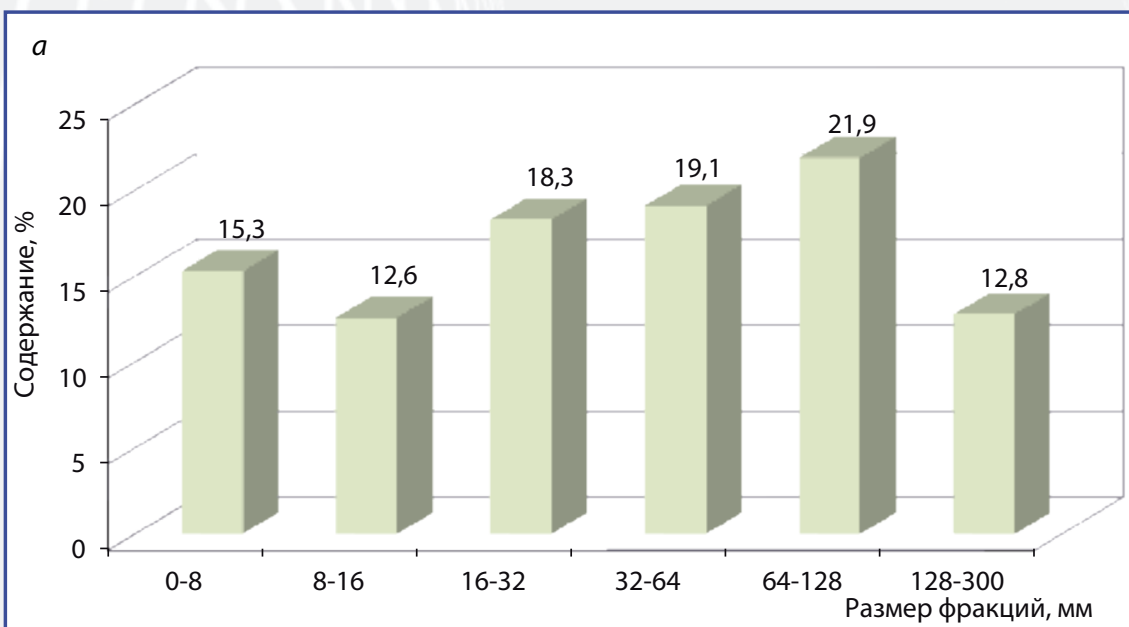

6

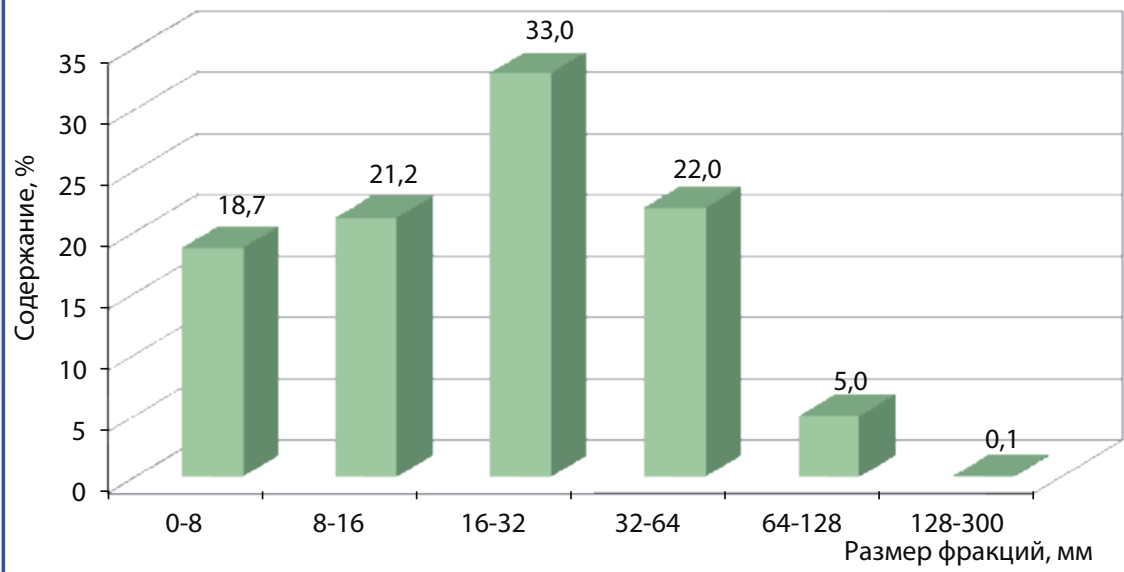

Рис. 8. Гранулометрический состав добытого известняка при традиционной (а) и фрезерной (б) технологиях отработки пород ся, а по фракции 32-64 мм базовая технология имеет сопоставимые с фрезерной технологией показатели (рис. 8).

В таких условиях оценка процесса дробления должна распространяться не на весь объем поступающего материала, а только на долю крупных фракций, которая отсутствует в технологиях, построенных на базе машин CSM.

Удельные энергозатраты на разработку карбонатных пород, аргиллитов и алевролитов с прочностью на одноосное сжатие от 15 до 30 МПа при традиционной технологии (БВР + экскавация) в 1,9-2,1 раза ниже безвзрывной технологии, базирующейся на применении горных комбайнов.

В этой связи решение в области использования фрезерных машин должно определяться на основе экономических расчетов. Тем не менее, существуют определенные (рамочные) ограничения по их применению, связанные с геологическими и технологическими факторами.

Основными лимитирующими геологическими факторами являются прочность и абразивность горных пород. Увеличение прочности пород с 10-20 до 50-80 МПа вызывает резкое возрастание энергоемкости процесса резания, что предопределяет многократное падение производительности машин до уровней, во многих случаях не обеспечивающих параметры проектируемых технологических грузопотоков карьера и уровень приемлемой экономической эффективности.

Важная закономерность при эксплуатации фрезерных комбайнов связана с изменением гранулометрического состава отбиваемых пород от их прочностных свойств. Экспериментальные работы, выполненные на ряде карбонатных и рудных карьеров, свидетельствуют, что с увеличением прочности пород крупность отбитого материала уменьшается (рис. 9).

Один из основных эксплуатационных показателей работы фрезерных машин - это износостойкость резцов. Одним из ключевых факторов здесь является уровень абразивности исходных пород, определяемый содержанием кварца. Увеличение содержания кварцсодержащих пород свыше 2-3\% ведет к интенсивному износу резцов (табл. 2) [4].

Применительно к фрезерным машинам CSM фирм Wirtgen, Huron, Tenova TAKRAF фактором, ограничивающим их использование, являются мини- 
Область возможного применения фрезерных машин (по совокупности лимитирующих геологических и технологических факторов)

\begin{tabular}{|c|c|c|c|}
\hline \multicolumn{4}{|c|}{ Лимитирующие факторы } \\
\hline Характеристика условий применения & $\begin{array}{c}\text { Наличие } \\
\text { кварцсодержащих } \\
\text { пород, \% }\end{array}$ & $\begin{array}{c}\text { Крепость пород } \\
\text { на одноосное сжатие } \sigma_{\text {сж' }} \text {, } \\
\text { МПа }\end{array}$ & $\begin{array}{c}\text { Наличие крепких } \\
\text { включений } \\
c \sigma_{c ж}>100 \mathrm{MПа}, \%\end{array}$ \\
\hline Применение без ограничений & $0-2$ & $10-30$ & $0-1$ \\
\hline Возможно применение & $2-6$ & $30-60$ & $1-5$ \\
\hline Проблемные условия для использования & $6-10$ & $60-70$ & $5-7$ \\
\hline Применение нецелесообразно & $>10$ & $>70$ & $>7$ \\
\hline
\end{tabular}

мальные размеры выемочной зоны. В таких условиях (размер выемочной зоны менее $300 \times 100$ м) использование данных машин становится нецелесообразным вследствие увеличения доли операций на врезки и развороты.

\section{ОТРАБОТКА ГОРНЫХ ПОРОД КОМПАКТНЫМИ}

\section{РОТОРНЫМИ ЭКСКАВАТОРАМИ}

При отработке горныхмассивов, сложенных породами малой и средней прочности, для формирования потока материала (руды, угля, вскрышных пород), пригодного для перемещения конвейерным транспортом, в составе комплексов ЦПТ могут использоваться компактные роторные экскаваторы с повышенными усилиями резания (>12 кгс/ $\left.\mathrm{cm}^{2}\right)$.

Перед экскавацией такие массивы ослабляются посредством взрывов на «встряхивание», что позволяет в 2-3 раза снизить энергоемкость резания массива горных пород роторным экскаватором. Последнее ведет к адекватному возрастанию производительности роторныхэкскаваторов и снижению динамических нагрузок на металлоконструкции машин. Иллюстрацией здесь могут быть графики, показывающие взаимосвязь технической производительности роторных машин SRs(k)-470 с энергоемкостью резания при экскавации целика и массива, предварительно ослабленного взрывом на «встряхивание» (рис. 10) [4].

В отличие от комплексов поточной технологии погрузка экскавируемого материала роторным экскаватором выполняется не на конвейер, а в средства автомобильного транспорта, с последующей перегрузкой в конвейерный транспорт через бункер.

Перспективным направлением поточной технологии производства горных работ на угольных месторождениях с углами залегания пластов 3-12 являются схемы, при которых отработка добычных уступов осуществляется наклонными выемочными слоями. При такихуглах залегания пластов магистральные конвейерные подъемники располагаются на почве нижнего угольного пласта и периодически удлиняются в процессе понижения горных работ.
Примером здесь может служить диагональная схема производства добычных работ на разрезе «Восточный» (рис. 11), предложенная УкрНИИпроектом [5]. Данная схема позволяет в условиях разреза «Восточный» в полной степени использовать технические возможности непрерывной техники (роторных экскаваторов, перегружателей и конвейерного транспорта) при значительном снижении металло- и энергоемкости схемы за счет сокращения в два раза количества конвейеров, а также при исключении процессов демонтажно-монтажных работ по конвейерам внутри разреза.

На крупных угольных карьерах, использующих мощные роторные экскаваторы, добычные комплексы ЦПТ могут быть укомплектованы следующим образом: 


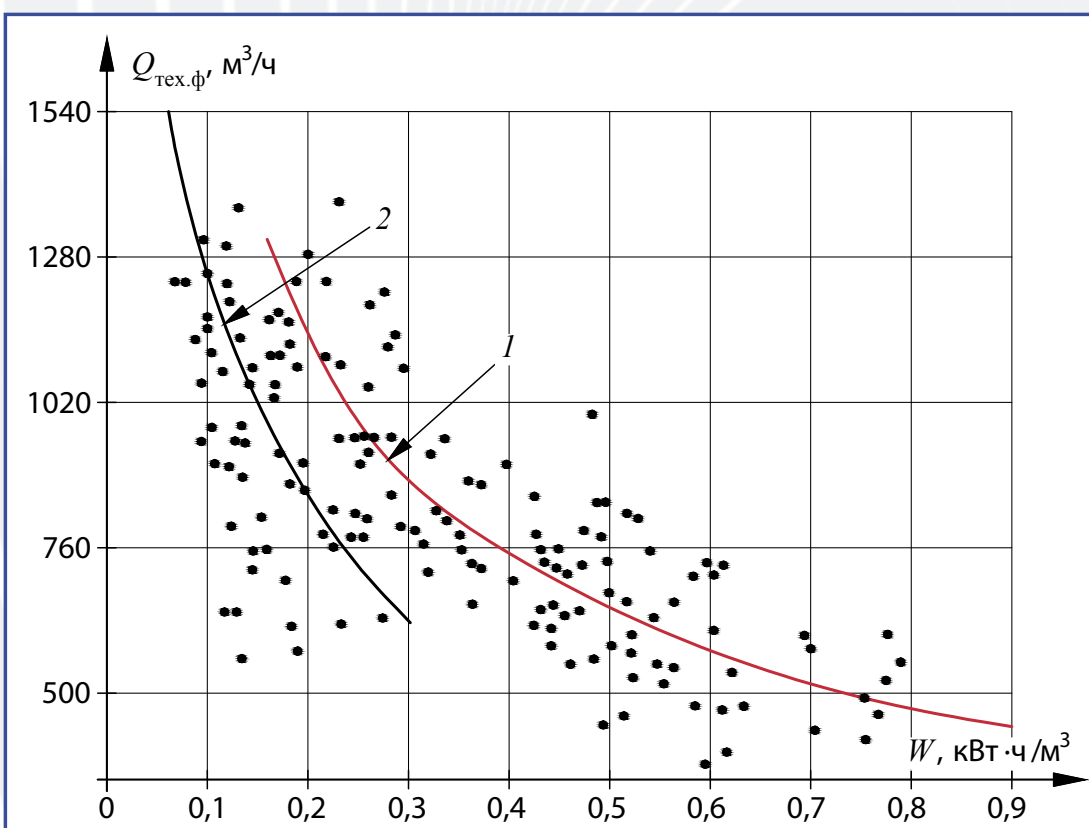

Рис. 10. Взаимосвязь фактической технической производительности и энергоемкости экскавачии при разработке экскаваторами $S R s(k)-470$ челика (1) и взорванного массива (2) при расходе ВВ 0,18 кг/м³ (по В.М. Владимирову)

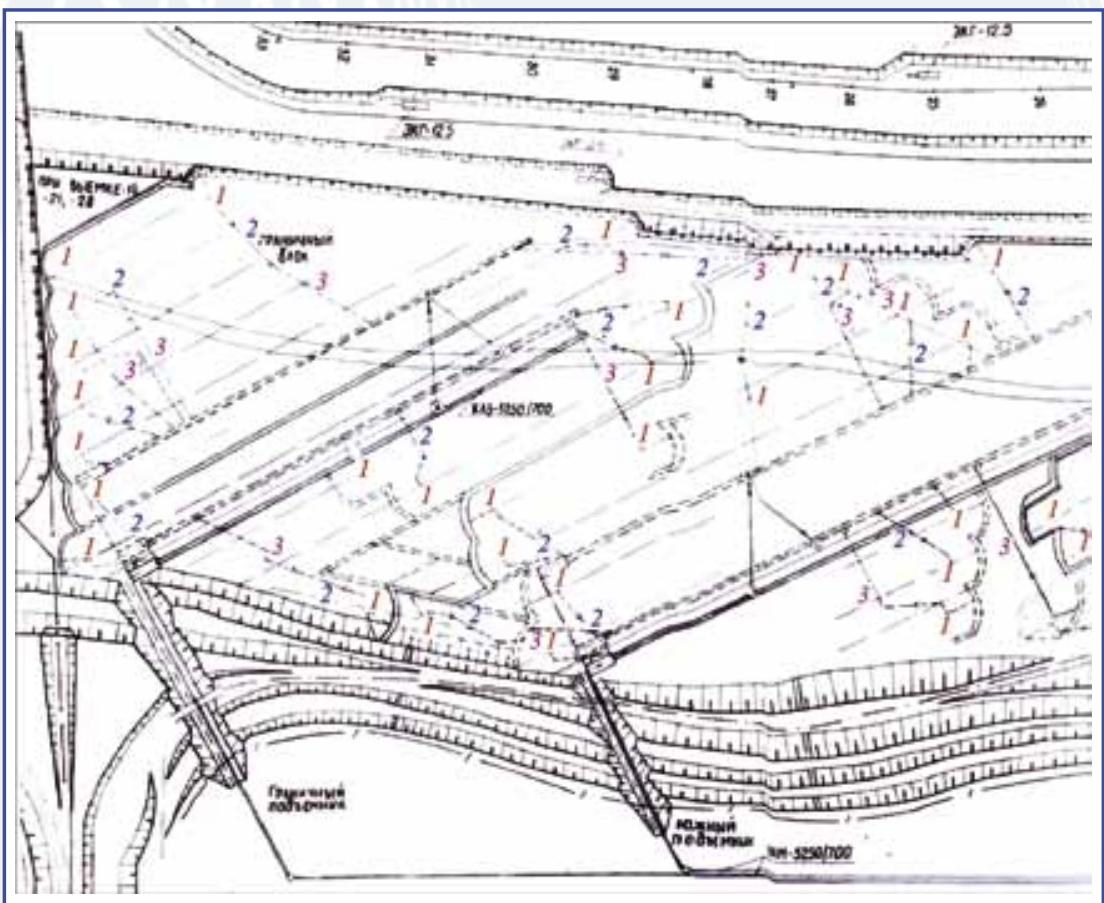

Рис. 11. Система разработки комплексом поточной технологии с диагональным фронтом (разрез «Восточный»): 1 - роторный экскаватор $S R s(k)-2000 ; 2$ - забойный перегружатель BRs(k)-2000.65;

3 - межуступный перегружатель ARs(k)-5500.95 [5]

технологию добычи и усреднения угля в объеме 40 млн т в год. Фактический объем отгрузки угля комплексом ЦПТ на разрезе «Богатырь» составляет около 14 млн т в год (рис. 12).

Данный комплекс предусматривает использование на выемке угля экскаваторов «Liebherr» R 9350 с вместимостью ковша 17 м $^{3}$ и автосамосвалов БелА3-75131, Cat-777 и Cat-785 [6].

Подача угля автомобильным транспортом осуществляется на внутрикарьерный усреднительный склад, оборудованный роторным экскаватором $\mathrm{SRs}(\mathrm{k})-2000$. Роторный экскаватор в данном случае используется как дробильноусреднительный агрегат, доводящий подаваемую угольную массу (за счет резания в забое и работы встроенной молотковой дробилки) до фракции 0-300 мм с ее последующей погрузкой на забойный конвейер (рис. 13). Далее по забойному и соединительному (наклонному) конвейерам уголь подается на погрузочный комплекс (УППК), расположенный на горизонте +45 м стационарного южного борта разреза «Богатырь».

\section{РАЗБОРКА СЛОИСТЫХ МАССИВОВ ПОСРЕДСТВОМ ГИДРОМОЛОТОВ}

И ГИДРАВЛИЧЕСКИХ ЭКСКАВАТОРОВ

При небольшой мощности грузопотоков минерального сырья подготовка исходных пород для дробления в дробильных станциях комплексов ЦПТ может выполняться с использованием гидравлических экскаваторов и гидромолотов путем внедрения их рабочих органов в межслоевые контакты, заполненные, как правило, мергелями. С их помощью реализуется безвзрывная технология производства горных работ. Для разрушения массивов горных пород на карьерах широко применяются гидромолоты, смонтированные на базе гидравлических экскаваторов. Прогресс в развитии гидромолотов и виброрипперов привел к тому, что данное оборудование можно рассматривать как основной способ подготовки скальных пород для дробильных станций комплексов ЦПТ, используе-

- отгрузка угля из забоя выполняется одноковшовым экскаватором;

- доставка угля до штабеля усреднительного склада осуществляется автомобильным транспортом;

- додрабливание угля до фракции 0-350 мм с последующей отгрузкой на конвейер производится роторным экскаватором.

Проектом расширения разреза «Богатырь» (Экибастузский угольной бассейн) предполагается полный переход на циклично-поточную (автомобильно-конвейерную) мых на карьерах небольшой производственной мощности. Наиболее эффективные схемы разработки слоистых массивов основаны на совместной работе комплекса экскаваторов, оснащенных ковшами типа «обратная лопата» и гидромолотами (рис. 14).

Экскаватор с ковшом «обратная лопата» выполняет работу по разборке массива и погрузке материала в автотранспорт, перемещающий его к дробильной станции комплекса ЦПТ. Данный экскаватор также выкладывает в один слой на нижней площадке уступа негабаритные 
блоки (крупные геологические отдельности), а экскаватор с гидромолотом выполняет их дробление. В процессе отработки уступа экскаваторы меняются местами, и разрушенные гидромолотом негабаритные блоки загружаются в автотранспорт (рис. 15).

Использование полностью мобильных дробильных установок, передающих раздробленный материал на забойный конвейер комплекса ЦПТ, позволяет исключить из технологической схемы автомобильный транспорт (рис. 16) [7].

Успех безвзрывной экскаваторной разборки слоистых массивов определяет не только прочность исходных пород, но и силы сцепления межслоевых контактов с геологическими отдельностями. Основываясь на вышесказанном, многие массивы осадочных пород (или зоны в пределах массивов), сложенные прочными породами, легко разбираются по плоскостям слабых межслоевых контактов [8].

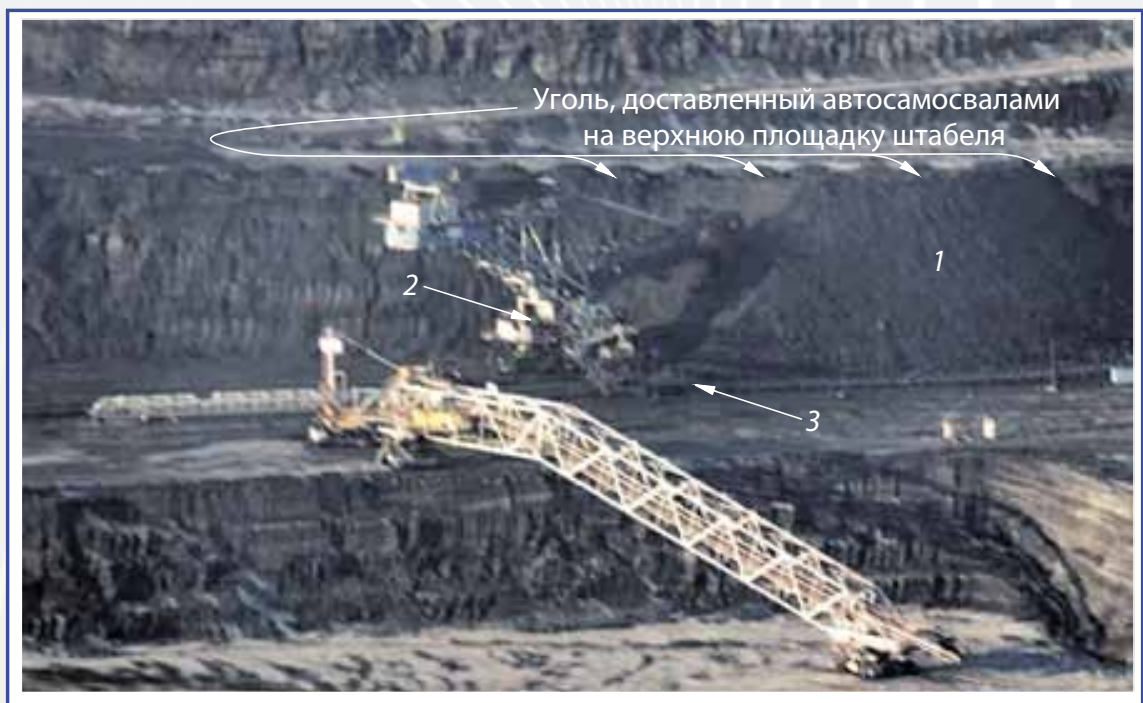

Рис. 12. Технологическая схема ЦПТ на разрезе «Богатырь» (Экибастузский угольный бассейн, Казахстан), предполагающая выемку угля одноковшовыми экскаваторами, доставку его в усреднительно-аккумулирующий штабель (1) автотранспортом с последующим додрабливанием угля роторным колесом и встроенной дробилкой роторного экскаватора (2) и погрузкой дробленого угля (фракции 0-350 мм) на забойный конвейер (3)

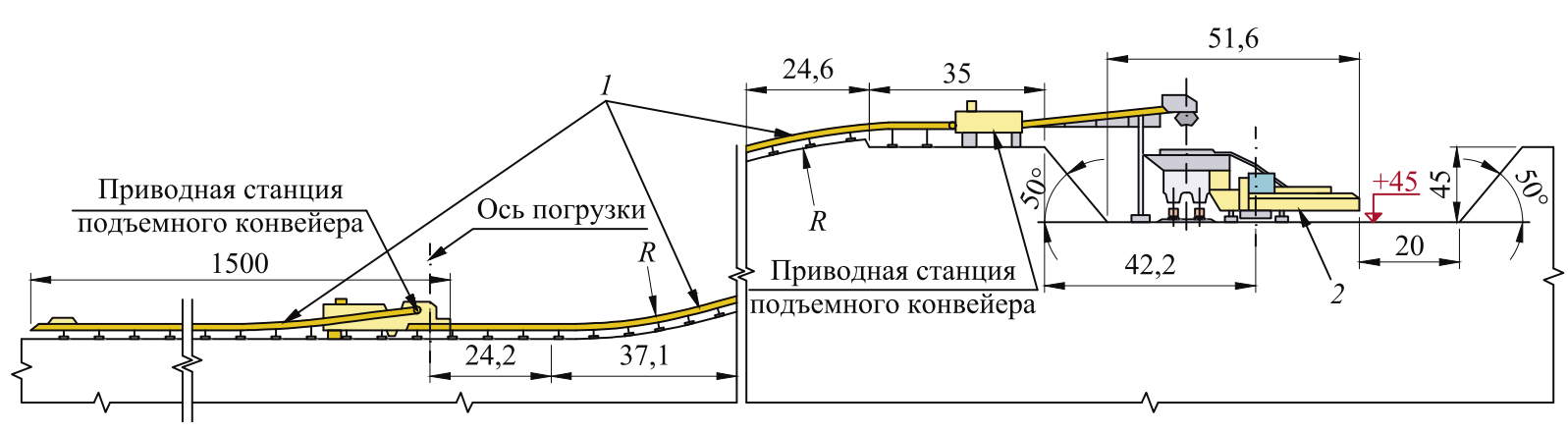

Рuc. 13. Схема конвейерной линии (1) на участке стационарного борта разреза «Богатырь», замыкаемая на комплекс погрузки угля (2)

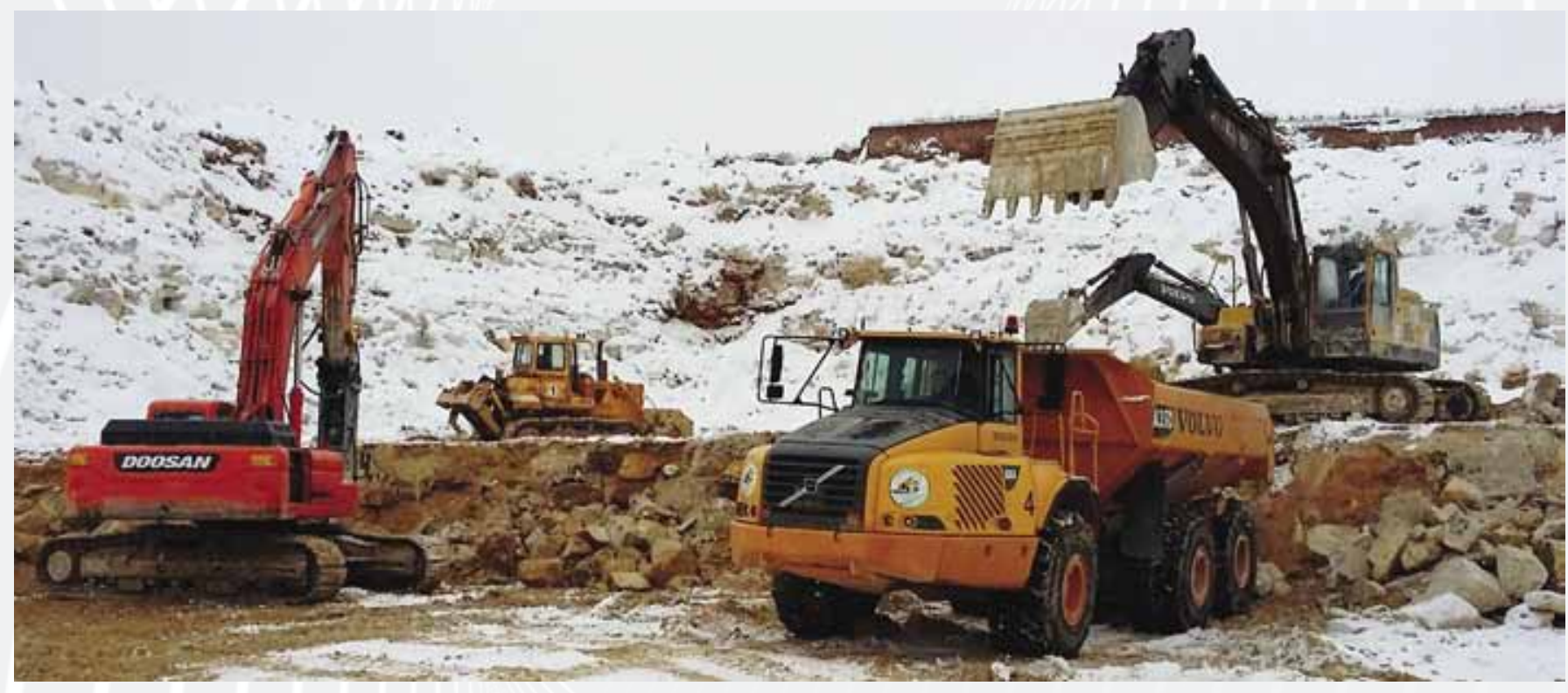

Рис. 14. Работа комплекса выемочно-погрузочного оборудования (гидравлический экскаватор «обратная лопата» гидравлический экскаватор с гидромолотом) при разборке слоистого карбонатного массива с мощностью разностных слоев oт 0,3 до 0,8 м в пределах одного технологического уступа (Акатьевский карьер) 


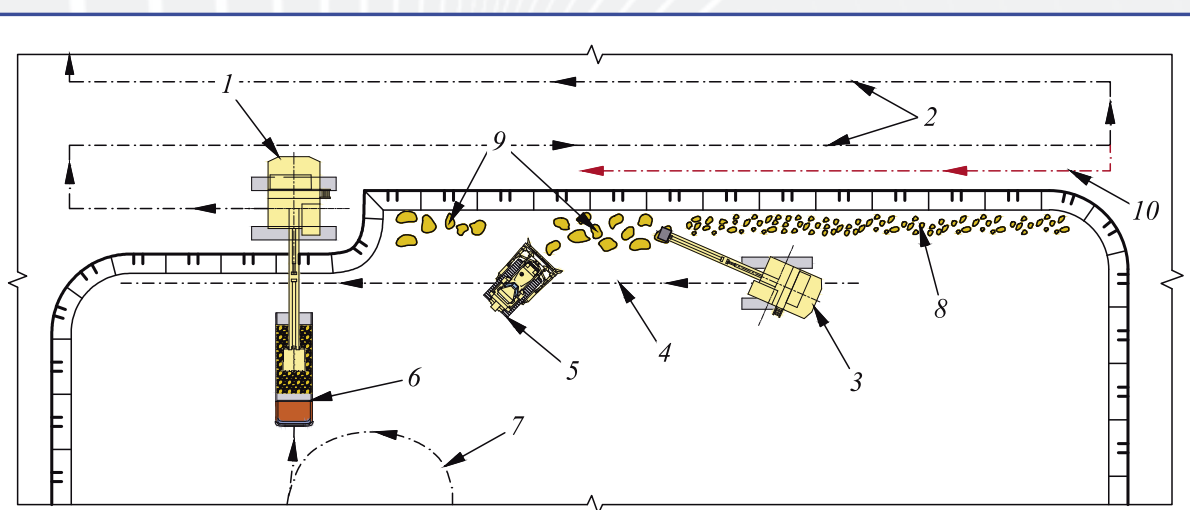

Рис. 15. Технологическая схема работы комплекса оборудования по разборке трещиноватого массива: 1 - гидравлический экскаватор «обратная лопата»; 2 - траектория передвижения гидравлического экскаватора; 3 - гидравлический экскаватор с гидромолотом; 4 - траектория движения гидравлического экскаватора с гидромолотом; 5 - бульдозер; 6-автосамосвал, транспортирующий породу к дробильной станции комплекса ЦПТ; 7- траектория движения автосамосвала; 8 - раздробленные негабаритные геологические отдельности; 9 - негабаритные геологические отдельности; 10 - траектория движения экскаватора 1 при отгрузке раздробленных негабаритных блоков (крупных геологических отдельностей)

Конвейерный транспорт в комплексе с горными комбайнами или компактными роторными экскаваторами позволяет снизить затраты на перемещение отрабатываемых пород по сравнению с цикличным автотранспортом. Преимуществом вышеприведенного выемочнопогрузочного оборудования является отсутствие необходимости дробления пород перед погрузкой на конвейер, что позволяет исключить из технологической цепочки дробильные установки. Использование конвейерного транспорта, при прочих равных условиях позволяет увеличить производительность выемочно-погрузочного оборудования.

Технологии, основанные на процессе резания, имеют существенные ограничения по физикомеханическим свойствам горных

Использование гидромолотов сопровождается разрушением геологических отдельностей в большинстве случаев до размеров 200-800 мм (разрушение материала до фракций менее уровня 200 мм по технологическим и экономическим причинам нецелесообразно), что удовлетворяет требованиям последующих стадий дробления. Дробление геологических отдельностей взрывом, по сравнению с их разрушением гидромолотом, не позволяет выполнить точное регулирование размеров получаемого материала, при этом фракционный состав обычно укладывается в интервал 0-1500 мм (доля мелких фракций 0-32 мм составляет от 35 до 45\%).

\section{ЗАКЛЮЧЕНИЕ}

Применение рассмотренных технологий позволяет частично или полностью исключить взрывную подготовку горных пород к выемке, что позволяет улучшить экономические показатели работы горного предприятия. пород (прочность, абразивность, зернистость и другие). Разрушение пород прочностью более 50 МПа с присутствием крепких включений более 5\% значительно сокращает производительность машин с фрезерными рабочими органами и зачастую делает их использование нецелесообразным.

Процессы резания и разборки массивов имеют принципиально различные показатели энергоемкости выемки горных пород. Энергоемкость процесса резания (для однотипных пород) в 2,5-3,5 раза выше, чем при экскаваторной разборке. Однако гранулометрический состав материала, получаемого в ходе процесса резания значительно меньше, чем при экскаваторной разборке массива.

Окончательное решение по выбору оптимальной технологии и технологических схем безвзрывной подготовки скальных горных пород к перемещению конвейерным транспортом должно приниматься на основе техникоэкономических расчетов с сопоставлением различных вариантов отработки массива.

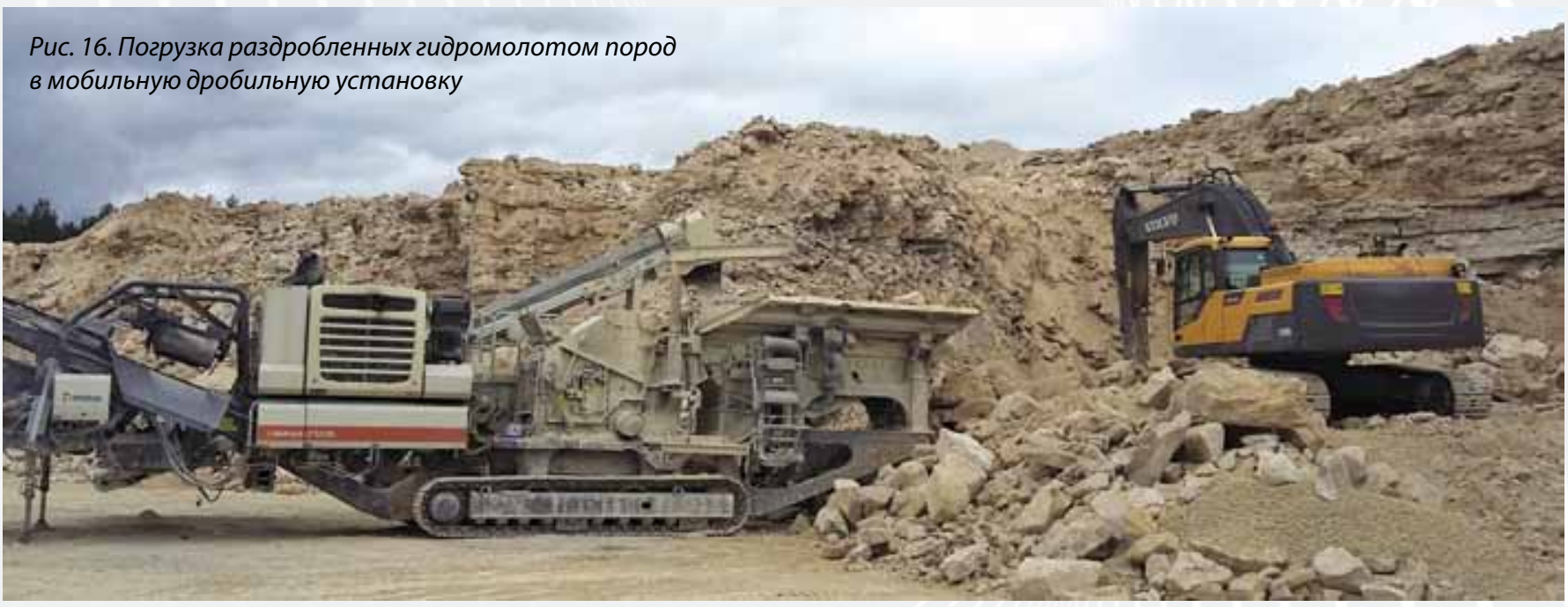




\section{Список литературы}

1. Steve Onorofskie. Economical mining of gypsum with Wirtgen surface miners in an ecologically sensitive environment // Презентация. 2006.

2. D. Carlos Lopez Jimeno, D. Emilio Lopez Jimeno, D. Santiago Manglano Alonso, D. Jose M. Toledo Santos. Manual de arranque, carga y transporte en minería a cielo abierto. Instituto tecnologico geominero de Espana. 1995. 604 p.

3. Dragoljub Ciric, Belgrad and Christian Niemann-Delius, Pheinhausen. Mining techniques and profitability of Continuous Surface Miners for tno open-pit coal mines in Yugoslavia based on Krupp Surface Miners // Braunkohle. 1991. N 11.

4. Перспективная техника и технологии для производства открытых горных работ / В.И. Супрун, В.Б. Артемьев, П.И. Опанасенко и др. М.: Издательство «Горное дело» ООО «Киммерийский центр», 2017.

5. Отчет о научно-исследовательской работе «Разработать исходные данные для дополнительных проектных проработок горнотранспортной части добычных работ и оказать научно-техническую помощь при проектировании 3-го и 4-го пусковых комплексов на разрезе «Восточный» / А.Н. Пинчук, В.И. Слепян, А.Т. Галимуллин и др. Киев: УкрНИИпроект, 1985. 120 с.

6. Щукин В.К., Мелехов Д.П. Трансформация технологий добычи угля на разрезах Экибастузского месторождения, новые решения - путь к мировым стандартам // Уголь. 2015. № 6. С. 12-16. URL: http://www.ugolinfo.ru/ Free/062015.pdf (дата обращения: 15.09.2018).

7. Мировой опыт эксплуатации комплексов цикличнопоточной технологии с внутрикарьерным дроблением / К. Дребенштедт, Р. Риттер, В.И. Супрун, Ю.Г. Агафонов // Горныйжурнал. 2015. №11. С. 81-87. doi: 10.17580/gzh.2015.11.17.

8. Стромоногов А.В. Обоснование безвзрывной технологии добычи блоков известняка на карбонатных месторождениях Русской платформы: дис. ...канд. техн. наук. М., 2017. 136 c.

SURFACE MINING

UDC 622.271:622.682 @ S.V. Burtsev, Ya.V. Levchenko, V.V. Talanin, K.S. Voroshilin, 2018

ISSN 0041-5790 (Print) • ISSN 2412-8333 (Online) • Ugol' - Russian Coal Journal, 2018, № 10, Pp. 8-17

Title

BLASTLESS TECHNOLOGIES FOR ROCK MASS CONDITIONING FOR CONVEYOR TRANSPORTATION

DOI: http://dx.doi.org/10.18796/0041-5790-2018-10-8-17

\section{Authors}

Burtsev S.V. ${ }^{1}$, Levchenko Ya.V. ${ }^{2}$, Talanin V.V. ${ }^{2}$, Voroshilin K.S. ${ }^{2}$

1 "SBU-Coal" Holding Company JSC, Kemerovo, 650066, Russian Federation

${ }^{2}$ National University of Science and Technology "MISIS" (NUST "MISIS"), Moscow, 119049, Russian Federation

\section{Authors' Information}

Burtsev S.V., PhD (Economic), First Deputy General Director, Technical Director, e-mail: s.burtsev@sds-ugol.ru

Levchenko Ya.V., PhD (Engineering), Senior Lecturer, Assistant Professor Talanin V.V., PhD (Engineering), Assistant Professor

Voroshilin K.S., Senior Lecturer

\begin{abstract}
The paper addresses basic blastless technologies for rock mass conditioning in combination with conveyor transport. It presents the concepts of milling machines operation and their process flow diagrams. It provides the comparative analysis of blastless vs blast technology energy efficiency and particle size. It lists constraining rock properties physical-mechanical factors for rock processing using mining machinery mill heads. It gives overview of compact rotary excavators and hydrohammers utilization with account for rock mass preliminary blasting for "shaking". It demonstrates the range of blastless rock mining equipment application.
\end{abstract}

\section{Keywords}

Blastless technology, Conveyor transport, Milling machines, Energy efficiency, Compact rotary excavators, Hydrohammers, Conveyor ore transportation complex, Rock particle size, Rock mass excavation sorting.

\section{References}

1. Steve Onorofskie. Economical mining of gypsum with Wirtgen surface miners in an ecologically sensitive environment. Presentation, 2006.

2. D. Carlos Lopez Jimeno, D. Emilio Lopez Jimeno, D. Santiago Manglano Alonso, D. Jose M. Toledo Santos. Manual de arranque, carga y transporte en minería a cielo abierto. Instituto tecnologico geominero de Espana, 1995, $604 \mathrm{p}$.
3. Dragoljub Ciric, Belgrad \& Christian Niemann-Delius, Pheinhausen. Mining techniques and profitability of Continuous Surface Miners for tno open-pit coal mines in Yugoslavia based on Krupp Surface Miners. Braunkohle, 1991, No. 11.

4. Suprun V.I., Artemiev V.B., Opanasenko P.I. et al. Perspektivnaya tekhnika i tekhnologii dlya proizvodstva otkrytyh gornyh rabot [Advanced machinery and technologies for surface mining]. Moscow, Gornoe delo Kimmeriyskiy tsentr LLC., 2017.

5. Pinchuk A.N., Slepyan V.I., Galimullin A.T. et al. Otchet o nauchno-issledovatelskoy rabote "Razrabotat iskhodnye dannye dlya dopolnitelnyh proektnyh prorabotok gornotransportnoy chasti dobychnyh rabot i okazat nauchnotekhnicheskuyu pomoshch pri proektirovanii 3-go i 4-go puskovyh kompleksov na razreze "Vostochnyy" [Report on scientific and research activity"Input data development for mining conveyor transport design development and scientific and technical assistance during 3 and 4 starter complexes design in "Vostochny" open-pit mine"]. Kiev, UkrNIIProekt Publ., 1985, 120 p. 6. Shchukin V.K. \& Melehov D.P.Transformatsiya tekhnologiy dobychi uglya na razrezah Ekibastuzskogo mestorozhdeniya, novye resheniya - put k mirovym standartam [Transformation of coal mining technologies on the open-pit mines of Ekibastuz minefield, new solutions - the way to the global standards]. Ugol' - Russian Coal Journal, 2015, No. 6, pp. 12-16. Available at: http:// www.ugolinfo.ru/Free/062015.pdf (accessed 15.09.2018).

7. Drebenshtedt K., Ritter R., Suprun V.I. \& Agafonov Yu.G. Mirovoy opyt ekspluatatsii kompleksov tsiklichno-potochnoy tekhnologii s vnutrikarernym drobleniem [International experience of continuous-cyclic complexes operation with inpit crushing]. Gornyy Zhurnal - Mining Journal, 2015, No. 11, Pp. 81-87. doi: 10.17580/gzh.2015.11.17.

8. Stromonogov A.V. Obosnovanie bezvzryvnoy tekhnologii dobychi blokov izvestnyaka na karbonatnyh mestorozhdeniyah Russkoy platform. Diss. kand. tekhn. nauk [Substantiation of limestones blocks mining by blastless technology in the Russian platform carbonate deposits. PhD (Engineering) diss.] Moscow, 2017, $136 \mathrm{p}$. 


\section{ГрУзОПОдЬеМНОетью}

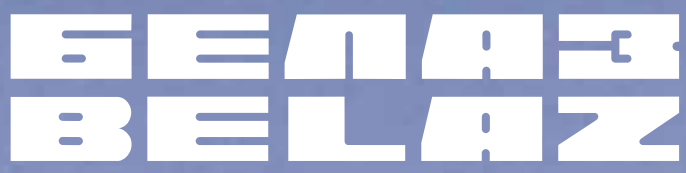

www.belaz.by

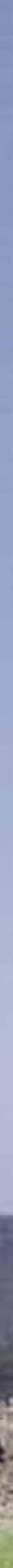

\section{КарБерный самосвал БЕЛАЗ-75180}

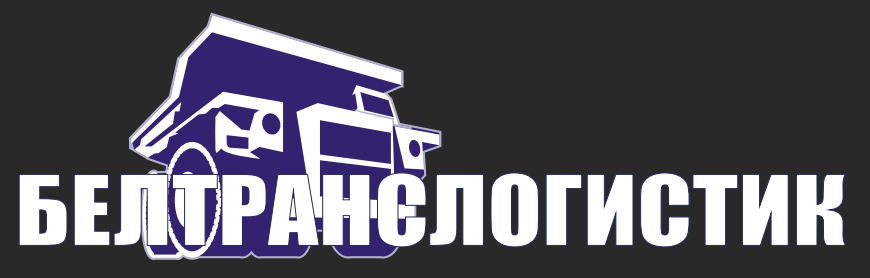

Официальный представитель ОАО «БЕЛАЗ»

www.btlogistic.ru

+7 (495) 544-51-36 


\section{Новое семейство карьерных самосвалов Б
сэлектромеханической трансмиссией грузоподъемностью 180 тонн}

\author{
ТРУХНОВ Леонид Иванович \\ Главный конструктор \\ ОАО «БЕЛАЗ» \\ 222161, г. Жодино, \\ Республика Беларусь \\ НАСКОВЕЦ Александр Михайлович \\ Начальник КБ компоновки \\ ОАО «БЕЛАЗ» \\ 222161, г. Жодино, \\ Республика Беларусь
}

В статье представлены конструктивные особенности и преимущества нового семейства карьерных самосвалов БЕЛАЗ с электромеханической трансмиссией грузоподъемностью 180 т, а также результаты эксплуатации и комплектация самосвала БЕЛАЗ-75180.

Ключевые слова: самосвал, квалификационные испытания, конструктивные особенности.

\section{ВВЕДЕНИЕ}

В наше время огромное значение в горнодобывающей промышленности уделяется такому критерию, как современные технологии. В сложившейся политической ситуации, когда большую роль играет развитие отечественной промышленности и поиск импортозамещения, Белорусский автомобильный завод совместно с российским предприятием ОАО «Электросила» решил разработать абсолютно новый продукт - карьерный самосвал БЕЛАЗ с электроприводом нового поколения с уникальными техническими характеристиками.

\section{СОЗДАНИЕ КАРЬЕРНОГО САМОСВАЛА С ЭЛЕКТРОМЕХАНИЧЕСКОЙ ТРАНСМИССИЕЙ ГРУЗОПОДЪЕМНОСТЬЮ 180 ТОНН}

В начале 2012 года на ОАО «БЕЛАЗ» - управляющая компания холдинга «БЕЛАЗ-ХОЛДИНГ» (далее - ОАО «БЕЛАЗ») был изготовлен первый опытный образец карьерного самосвала с электромеханической трансмиссией грузоподъемностью 180 т. В том же году самосвал успешно прошел приемочные испытания в условиях заводского полигона. В течение 2014-2015 гг. изготовлена опытно-промышленная партия машин в количестве 5 шт. и проведены квалификационные испытания, которые подтвердили готовность производства к выпуску новой серии карьерных самосвалов БЕЛАЗ-7518.

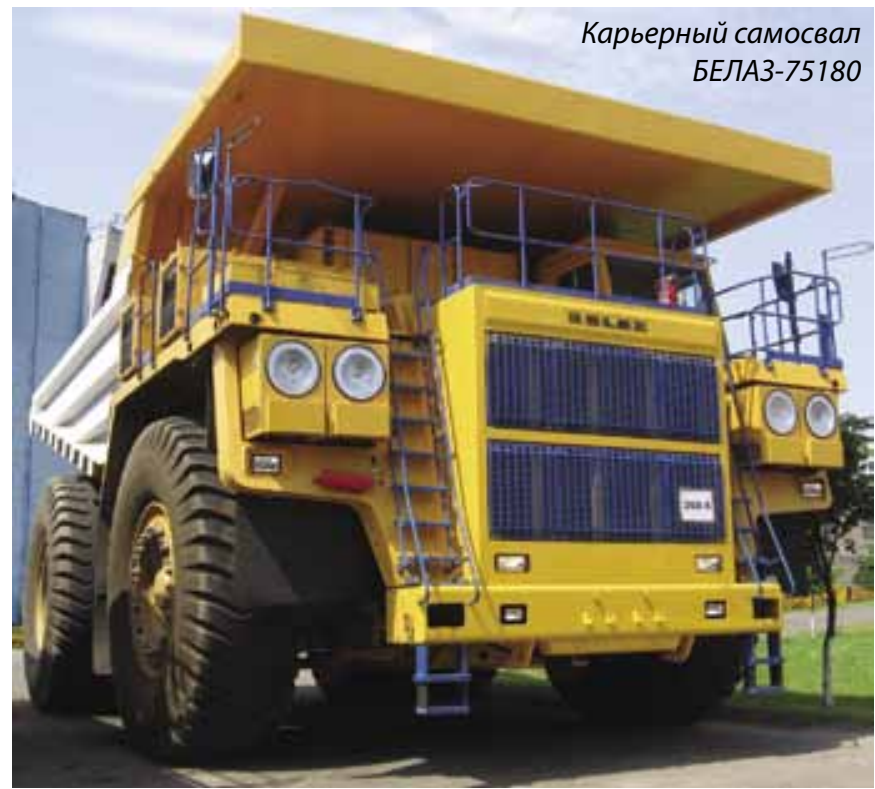

Первое шасси серии под индексом БЕЛАЗ-75180 было введено в эксплуатацию в 2014 г. в карьере Михайловского ГОКа. В течение эксплуатации машина показала отличные результаты как по производительности, так и по коэффициенту технической готовности.

Начальник управления автомобильного транспорта ОАО «Михайловский ГОК» А.Н. Коробков отметил: «Сегодня КТГдостиг 0,88 - это серьезные показатели по сравнению с другими моделями. Данный самосвал ничуть не уступает основному своему западному конкуренту - американскому Caterpillar-789».

Новой моделью уже заинтересовались представители других российских горнодобывающих компаний. Это позволяет говорить о новом витке в развитии партнерских отношений между Белоруссией и Россией.

После получения результатов эксплуатации, по инициативе Торгового дома «БелАЗ», в апреле 2015 г. была проведена презентация данной модели, в которой приняли участие ключевые потребители техники БЕЛАЗ - крупные горнодобывающие компании России: ОАО «Полиметалл», АО ХК «СДС-Уголь», ЗАО «ПОЛЮС», АО ХК «Якутуголь», «Стойленский ГОК».

Участникам презентации была предоставлена возможность ознакомиться с результатами работ данного карьерного самосвала. Один из самых важных вопросов, который волновал потребителей, - это показатели работы техники за период эксплуатации. В результате испытаний установлено, что при пробеге 70 тыс. км и наработке 6 тыс. моточасов коэффициент технической готовности составил 0,88 , а удельный расход топлива - 72,5 г/т·км. 


\section{КОНСТРУКТИВНЫЕ ОСОБЕННОСТИ}

\section{КАРЬЕРНОГО САМОСВАЛА БЕЛАЗ-75180}

Самосвал представляет собой двухосный технологический транспорт грузоподъемностью 180 т сжесткой литосварной рамой и задней разгрузкой, с колесной формулой 4×2, передними управляемыми и задними ведущими колесами. Данный вид машин предназначен для перевозки вскрышных пород и полезных ископаемых на открытых горных разработках, грунта и других сыпучих грузов вне дорог общего пользования и рассчитан на эксплуатацию в сложных горнотехнических условиях карьеров различной глубины и различных конфигураций.

На карьерном самосвале устанавливается дизельный четырехтактный двигатель с V-образным расположением цилиндров с электронным управлением и центральной отключаемой крыльчаткой системы охлаждения, непосредственным впрыском топлива, газотурбинным наддувом и промежуточным охлаждением наддувочного воздуха модели QSK 50-C фирмы Cummins, мощностью 1491 кВт (2000 л.с.) при 1900 мин ${ }^{-1}$. Высокая удельная мощность силовой установки в сочетании с электроприводом переменного тока четвертого поколения позволяет самосвалу развивать скорость до 60 км/ч, а также обеспечивать высокую топливную экономичность.

Двигатель оборудован пневмостартерным пуском, сухими трехступенчатыми воздушными фильтрами с автоматическим удалением пыли. Для облегчения пуска двигателя в условиях низких температур карьерные самосвалы оборудованы предпусковым подогревателем двигателя, который обеспечивает подогрев дизельного топлива и охлаждающей жидкости при запуске двигателя, а установка обогревателя топлива с фильтром на входе в двигатель обеспечивает устойчивую работу системы в различных климатических зонах, включая Крайний Север. Двухконтурная система охлаждения двигателя с отдельными контурами охлаждения позволяет эксплуатировать самосвалы в различных климатических условиях при температуре от -50 до $+50^{\circ} \mathrm{C}$.

Выпуск отработавших газов осуществляется через теплоизолированные трубопроводы и металлорукава оригинальной конструкции в газоприемник для обогрева грузовой платформы.

Карьерный самосвал БЕЛАЗ-75180 в карьере Михайловского ГОКа
Устанавливается топливный бак емкостью 2300 л, что позволяет работать 16-20 ч (в зависимости от условий эксплуатации) без дозаправки. Бак оснащен индикатором уровня и запираемой крышкой наливной горловины. Конструкция бака позволяет легко собирать и сливать конденсат с минимальной потерей топлива.

В состав самосвала БЕЛАЗ-75180 входит комплект тягового электропривода переменно-переменного тока КТЭ160 производства ПАО «Силовые машины». Электропривод состоит из двух тяговых электродвигателей ТАД-5 мощностью 610 кВт каждый, тягового генератора ГСТ-1600-8 мощностью 1600 кВт, шкафа электрооборудования ШУ-136.

Соотношение мощностной и скоростной характеристик тягового электропривода позволило приблизить характеристики машины к параметрам идеальной теоретической бесступенчатой трансмиссии, для которой не требуется переключение передач, сила тока и напряжение, подводимые к тяговым электродвигателям определяют крутящий момент и скорость движения самосвала, обеспечивая плавное изменение мощности при движении.

Современная система управления приводом обеспечивает возможность воздействия не только на тяговый электропривод, но и на дизельный двигатель, что позволяет формировать тяговые характеристики, оптимально сочетаемые с характеристиками дизельного двигателя. В конечном счете это позволяет снизить расход топлива при работе самосвала. Отсутствие щеточно-коллекторного узла позволяет снизить эксплуатационные затраты на обслуживание самосвала. Использование тормозных резисторов общей мощностью 2,4 МВт позволяет удерживать постоянную скорость 15 км/ч на 16\%-ном спуске, что способствует увеличению производительности самосвала.

Помимо этого в тяговом электроприводе реализованы следующие функции, улучшающие эксплуатационные характеристики самосвала:

- электрический дифференциал;

- противоюзовая система;

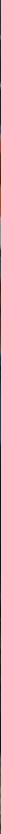


- противобуксовочная система;

- противооткатная система;

- система автоматического ограничения скорости;

- система стабилизации скорости на спуске;

- система контроля и диагностики.

Классическая колесная формула 4×2, примененная на самосвале в сочетании с направляющим аппаратом подвески, короткой базой и электромеханической трансмиссией переменного тока, обеспечивает высокую плавность хода, маневренность и хорошие тягово-динамические качества.

Принятая схема направляющего аппарата подвески снижает силу сухого трения по сравнению с самосваламианалогами в 2-4 раза, обеспечивает хорошую плавность хода и, соответственно, минимальные динамические нагрузки на оператора и узлы самосвала. Использование шаровых опор в цилиндрах подвески снижает трудоемкость и себестоимость ремонта, при ремонте требуется замена только вкладышей вместо шарнирных подшипников в сборе и не требуется демонтаж пальца подшипника, трудоемкость замены которого значительно вырастает в случае выработки в процессе эксплуатации.

Гидросистема привода рулевого управления, тормозов и опрокидывающего механизма - объединенная, что позволяет упростить и унифицировать гидропривод. Привод гидронасоса переменной производительности осуществляется от выходного фланца тягового генератора без применения дополнительного редуктора, что позволяет снизить потери мощности и исключить из конструкции радиатор для охлаждения гидропривода, достичь ресурса насосов до ремонта с учетом внедренной дополнительной системы фильтрации масла не менее 25 - 30 тыс. моточасов.

В стандартную комплектацию самосвала БЕЛАЗ-75180 входят предпусковой подогреватель жидкости, кондиционерно-отопительный блок, система комбинированного пожаротушения с дистанционным включением, автоматическая централизованная система смазки, система контроля загрузки и топлива, телеметрическая система контроля давления в шинах, система видеообзора, система предупреждения приближения к высоковольтным линиям.

По заказу потребителя возможно комплектование различными грузовыми платформами, обеспечивающими максимальное использование грузоподъемности самосвала в зависимости от плотности перевозимого груза. Также платформы могут комплектоваться футеровкой днища для защиты от износа при перевозке породы с большими абразивными свойствами.

\section{ЗАКЛЮЧЕНИЕ}

Внедрение карьерных самосвалов ОАО «БЕЛАЗ» серии БЕЛАЗ-75180 позволит не только удержать существующие рынки сбыта карьерной техники, но и выйти на новые. По предварительным маркетинговым исследованиям и анализу рынка, данная серия карьерных самосвалов востребована потребителями, а результаты испытаний и эксплуатации БЕЛАЗ-75180 доказали, что приобретение новой продукции предприятия позволит горнякам снизить эксплуатационные затраты и повысить производительность при перевозках.

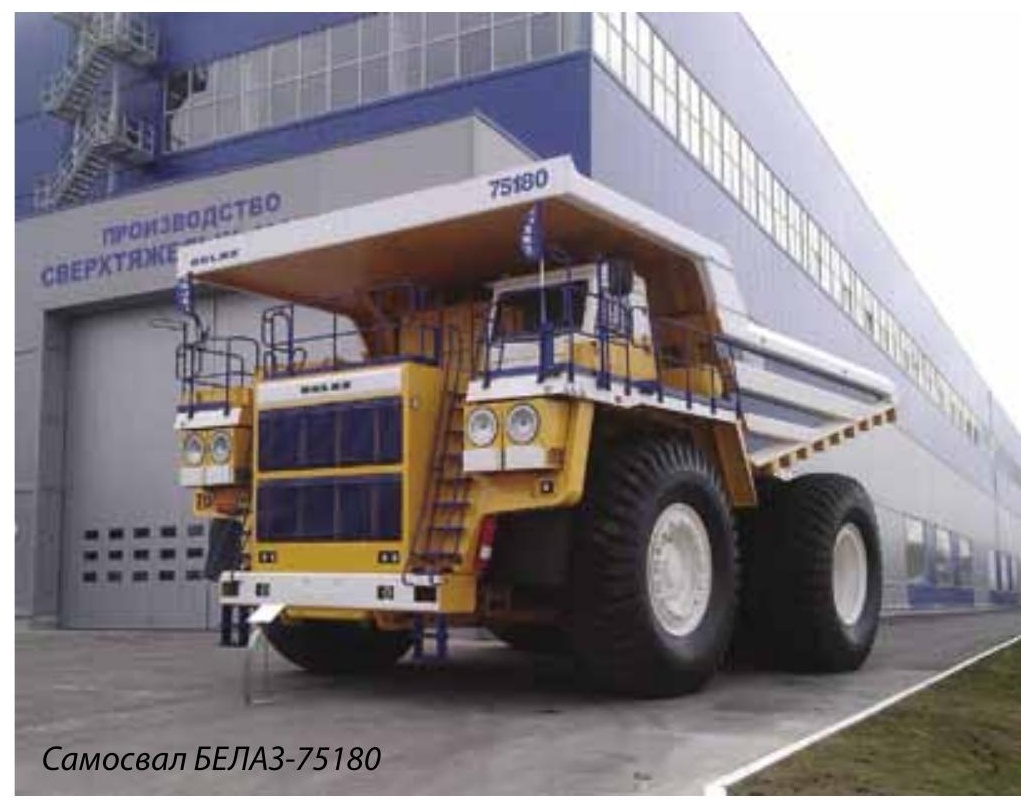

\section{Техническая характеристика карьерного самосвала БЕЛАЗ-75180}

\begin{tabular}{l|c}
\hline Грузоподъемность, т & 180 \\
\hline Модель двигателя & QSK 50-C \\
\hline Номинальная мощность двигателя, & $1491(2000)$ \\
\hline кВт (л.с.) при 1900 мин $^{-1}$ & 7865 \\
\hline Максимальный крутящий момент, & (при 1500 мин $^{-1}$ ) \\
\hline Н·м & 199 \\
\hline Удельный расход топлива & \\
при номинальной мощности, г/кВт·ч & ГСТ-1600-8 \\
\hline Тяговый генератор мощностью, кВт & 1600 \\
\hline Тяговый двигатель мощностью, кВт & ТАД-5 \\
\end{tabular}

Вместимость кузова, м: $^{3}$

\begin{tabular}{|l|c|}
\hline \multicolumn{1}{|c|}{ - геометрическая } & 78,5 \\
\hline - с «шапкой» 2:1 & 108,5 \\
\hline Шины размерностью & 37.00R57; 42/90R57 \\
\hline Радиус поворота, м & 14,5 \\
\hline Габаритный диаметр поворота, М & 30,0 \\
\hline Масса эксплуатационная, кг & 140000 \\
\hline Масса полная, кг & (комплектация без до- \\
\hline Молнительных систем)
\end{tabular}

По вопросам приобретения ПрОдУКциИ ОАО «БЕЛАЗ» обращайтесь

к официальному представителю

000 «БелтрансЛогистик»:

r. Mockвa,

Ул. Адмирала Руднева, А. 4, каб. 10. Тел.: +7 (495) 544-51-36 
XVV Международная специаливированная выставка

\section{«УГОЛЬ РОССИИ И МАЙНИНГ» ТХМекдуцародная специализированная выставка

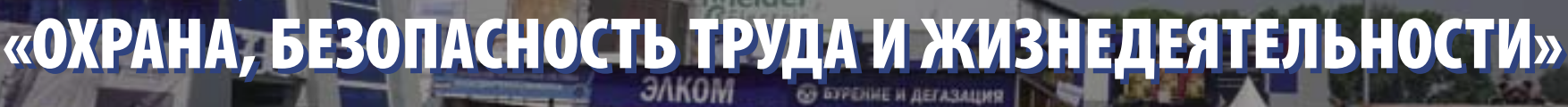

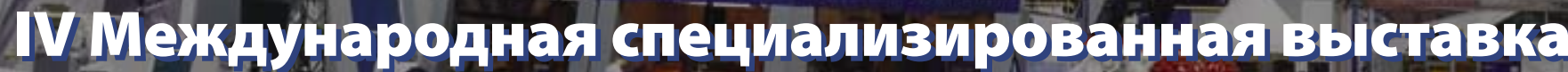
xis
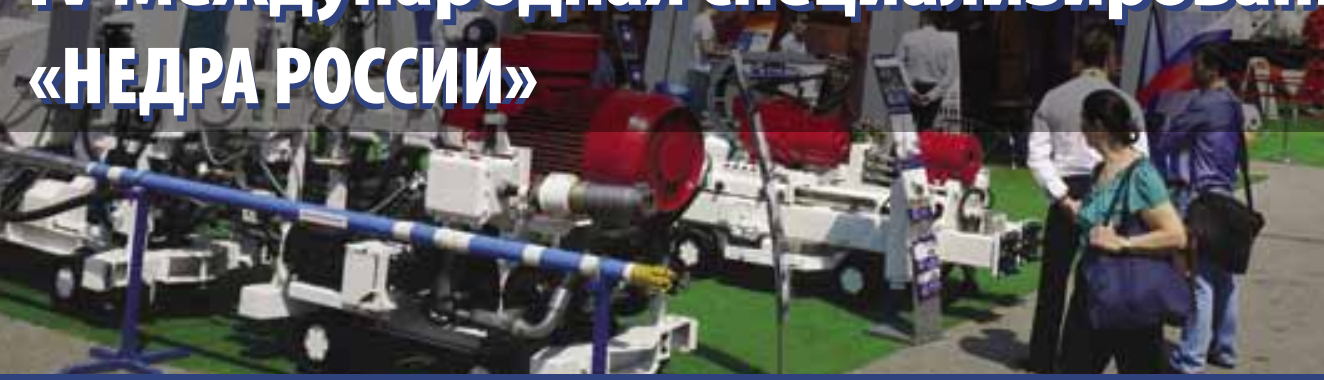

Mamepuajibi nozzomoвüra

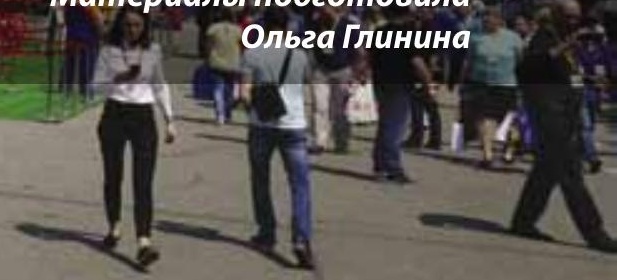

гоги, события, факты • итоги, события, факты • итоги, собbатия, факты • итоги

С 4 по 8 июня 2018 г. в г. Новокузнецке в выставочном комплексе «Кузбасская ярмарка» проходили XXV Юбилейная международная специализированная выставка технологий горных разработок "Уголь России и Майнинг», IX Международная специализированная выставка «Охрана, безопасность труда и жизнедеятельности» и IV Международная специализированная выставка «Недра России».

Организаторы мероприятий - выставочные компании «Кузбасская ярмарка» и «Мессе Дюссельдорф ГмбХ» (Германия).
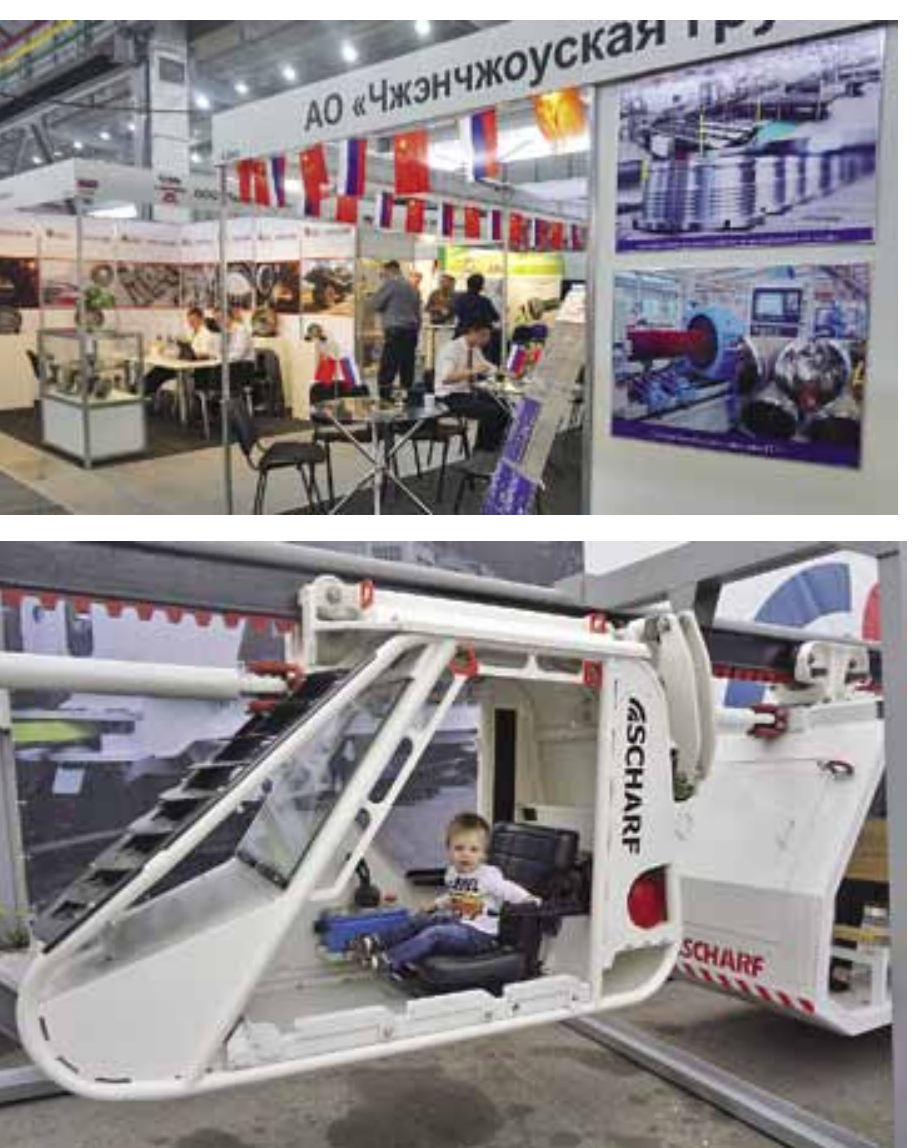

Сегодняшняя угольная промышленность Кузбасса серьезно отличается по уровню технической вооруженности, оснащенности современным оборудованием и, соответственно, производственными показателями от результатов двадцатилетней давности. Во многом это обеспечено внедрением современной техники и оборудования, в первую очередь зарубежного. В то же время и отечественные производители получают заказы и свою долю на рынке поставок угольным компаниям.

Отечественные машиностроители сами признают факт своего отставания от производителей США, Германии, Чехии и Польши. В отдельных случаях говорят, что могут предложить образцы техники, которые по соотношению цена/качество приближаются к зарубежным аналогам, но в целом признают существенную разницу в надежности и экономической эффективности. Тем более, что сами поставщики зарубежной техники не так уж и далеки от потребителей. Они уже давно и прочно обосновались в Кузбассе, обзавелись не только офисами, складами, но и сервисными центрами и, очевидно, не намерены уступать завоеванных ими позиций на рынке.

В этом году сотни компаний и десятки тысяч посетителей со всего мира собрались в Новокузнецке на угольных выставках для обсуждения трендов современной горнодобывающей промышленности в России и мире и тех вызовов, которые ставят перед индустрией все возрастающие запросы заказчиков. Многие из компаний представили собственные разработки от крупных единиц техники, до электронных систем автоматизации. Использование новой техники позволит горнодобывающим предприятиям не только увеличить эффективность и безопасность добычи полезных ископаемых, но и внести вклад в создание новых рабочих мест и общее экономическое развитие региона.

На площади 42500 кв. м оборудование, технику и разработки представили 626 компаний из 27 стран мира: Австралии, Австрии, Великобритании, Германии, Нидерландов, Дании, Израиля, Индии, Испании, Италии, Казахстана, Канады, Китая, Норвегии, Польши, Республики Беларусь, России, Словении, США, Турции, Украины, Финляндии, Франции, Чехии, Швейцарии, Швеции, Японии. 


\section{Продукция фирмы JDT}

Как и в предыдущие годы, фирма J.D. Theile GmbH \& Co. KG (JDT) с большим успехом приняла участие в выставке «Уголь России и Майнинг» в качестве экспонента.

На выставке были представлены запатентованная фирмой JDT цепь F-Class, а также плоские замки и замки типа Блок Theipa. Особый интерес вызвал разработанный фирмой JDT материал $\mathrm{HO}$ (highly optimized), применяемый для производства цепей для горнодобывающей отрасли, а также плоских (универсальных) замков и замков типа Блок Theiра по заказу клиента. В российских горнодобывающих шахтах и разработках материал НО уже доказал свою эффективность и преимущества с точки зрения решения технических задач, возникающих в процессе горной добычи.

Пользующийся большой популярностью среди посетителей стенд фирмы JDT дал возможность вступить представителям фирмы в непосредственный диалог со многими новыми и, конечно же, прежними заказчиками и покупателями, чтобы подробно рассказать о преимуществах продукции JDT.

Позитивный отклик, который получили представители фирмы в ходе профессионального общения, еще раз подтвердил, что продукция JDT благодаря ее выдающемуся качеству пользуется большим спросом и широко применяется в российской горнодобывающей отрасли.

J.D. Theile GmbH \& Co. KG - Letmather Straße 26 - D 58239 Schwerte - www.jdt.de

\section{Новая продукция компании HAZEMAG}

В спектре производства компании ХАЦЕМАГ Майнинг - погрузчики, самоходные буровые установки, буровое оборудование для бурения глубоких скважин, а также техника для проходки стволов. Все это оборудование, включая поставки запасных частей и сервисное обслуживание, теперь в России.

\section{Высокое качество и надежность от Hauhinco}

Компания Hauhinco является одним из ведущих поставщиков водногидравлических систем, насосов высокого давления, вентилей и компонентов. Высокое качество и надежность - это характерные достоинства выпускаемого оборудования. Об этом говорит и богатый производственный опыт, накопленный за более чем вековую историю компании.

\section{Электротехника для горной промышленности}

Оборудование BARTEC широко применяется во всех областях подземного электропривода, в особенности на конвейерном транспорте, где оно решает массу задач, связанных с экономией электроэнергии, безопасной эксплуатацией и улучшениями производственных показателей. Также BARTEC имеет большой опыт применения преобразовательной техники на вентиляторном, дробильном и подъемном оборудовании, насосной и дозаторной технике, в проходческих машинах и очистных комбайнах.

\section{Компания FLEXCO - решение задач}

\section{в области конвейерных систем}

Компания FLEXCO Europe GmbH является ведущим международным поставщиком механических ленточных конвейерных систем транспортирования, инновационных устройств для очистки ленты, узлов центрирования лент, ударно-отражательных поверхностей и облицовок барабанов для легких и тяжелых конвейерных лент транспортеров.
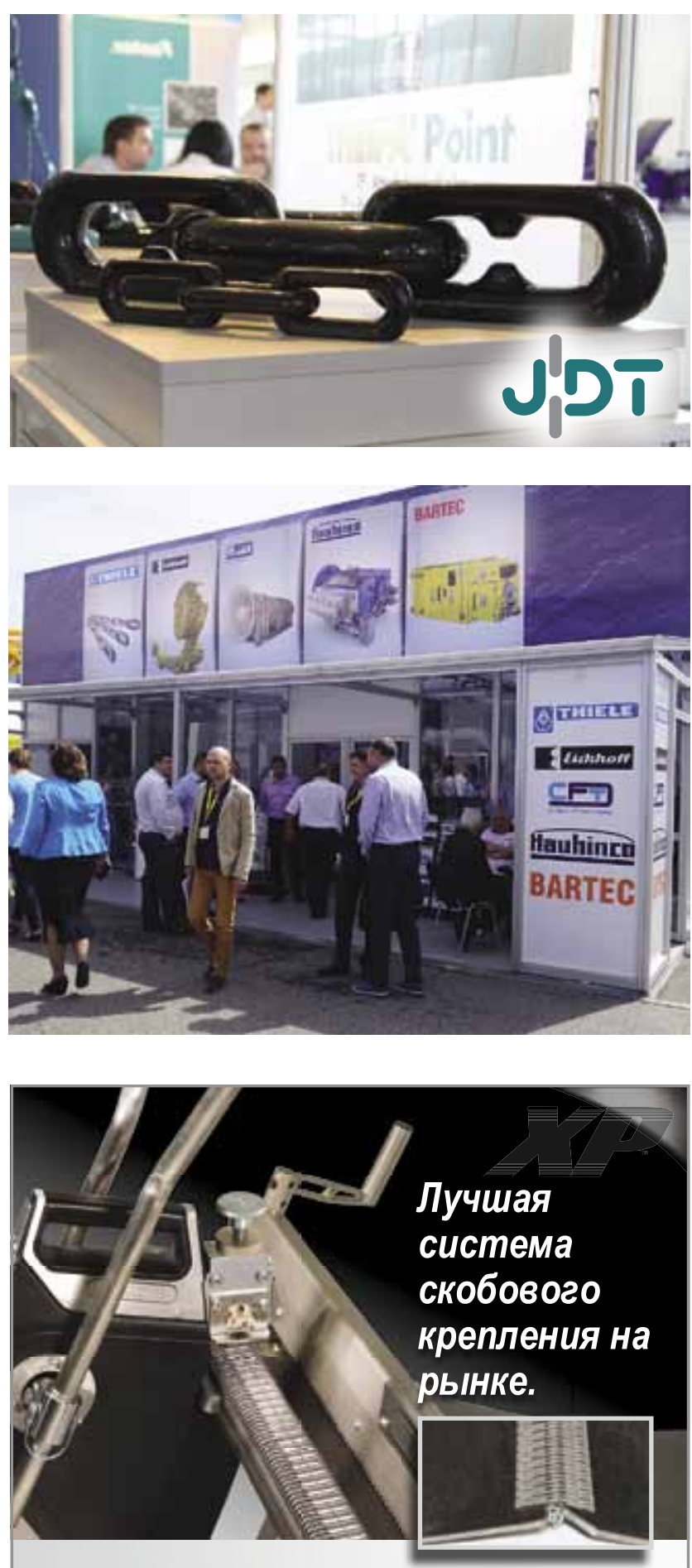

Система скобового крепления лент Flexco ${ }^{\circledR} \mathrm{XP}^{\text {Tw }}$ пропускать неправильно зоны крепления срок эксплуатации начиная работу заново. соединения увеличивается почти на $33 \%$.

- Разработана специально для применения с цельноткаными лентами

- Одна рукоятка управляет как перемещением, так и установкой креплений. из ПВГ/ПВХ, рассчитанными на нагрузки до $3500 \mathrm{kH} / \mathrm{M}$ и толщиной 16 мм.

Flexco Europe $\mathrm{GmbH}$ Leidringer Strasse 40-42 D-72348 Rosenfeld

Тел.: +49-7428-94060 Факс: +49-7428-9406260 europe@flexco.com

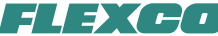

Partners in Productivity 
ООО «Беккер Майнинг Системс РУС»

Это единственное дочернее предприятие немецкого концерна Becker Mining Systems AG (Германия) на территории России является ежегодным участником прошедшей выставки. ООО «БМС РУС» традиционно представила на своем стенде как хорошо известное и зарекомендовавшее себя оборудование, так и последние новейшие разработки.

На собственной производственной площадке в Новокузнецке уже сейчас выпускается внушительный перечень продукции по немецким технологиям. На выставке был представлен дизель-гидравлический локомотив Becker российского производства, выполненный по оригинальной технологии завода-производителя транспортного оборудования группы Becker - «Becker-Warkop» (Польша). Локомотив является аналогом отлично зарекомендовавшего себя ДГЛ типа KPCS-95 и сохраняет все его преимущества: встроенная тормозная система, упрочненная конструкция приводного блока, сухая система охлаждения выхлопных газов, возможность использования на самых сложных участках трассы.

\section{Liebherr привез на выставку сразу несколько новинок оборудования \\ для горной промышленности}

На стенде № 1 немецкий производитель представил впервые поставленные в Россию колесный погрузчик L 586 XPower, короткобазовый внедорожный кран LRT 1100-2.1, а также дизельный двигатель D9812, специально доставленный с предприятия Liebherr-Components Colmar SAS во Франции

Новые внедорожные короткобазовые краны Liebherr являются мощным и надежным решением для выполнения работ в условиях бездорожья. Максимальная грузоподъемность LRT 1100-2.1 составляет 100 т. При этом он оснащается 50-метровой телескопической стрелой с системой Telematik, обеспечивающей независимое выдвижение каждой секции с помощью одного цилиндра.

Новое поколение колесных погрузчиков XPower, соответствующих экологическим нормам Евро IV / Tier 4f, ста-

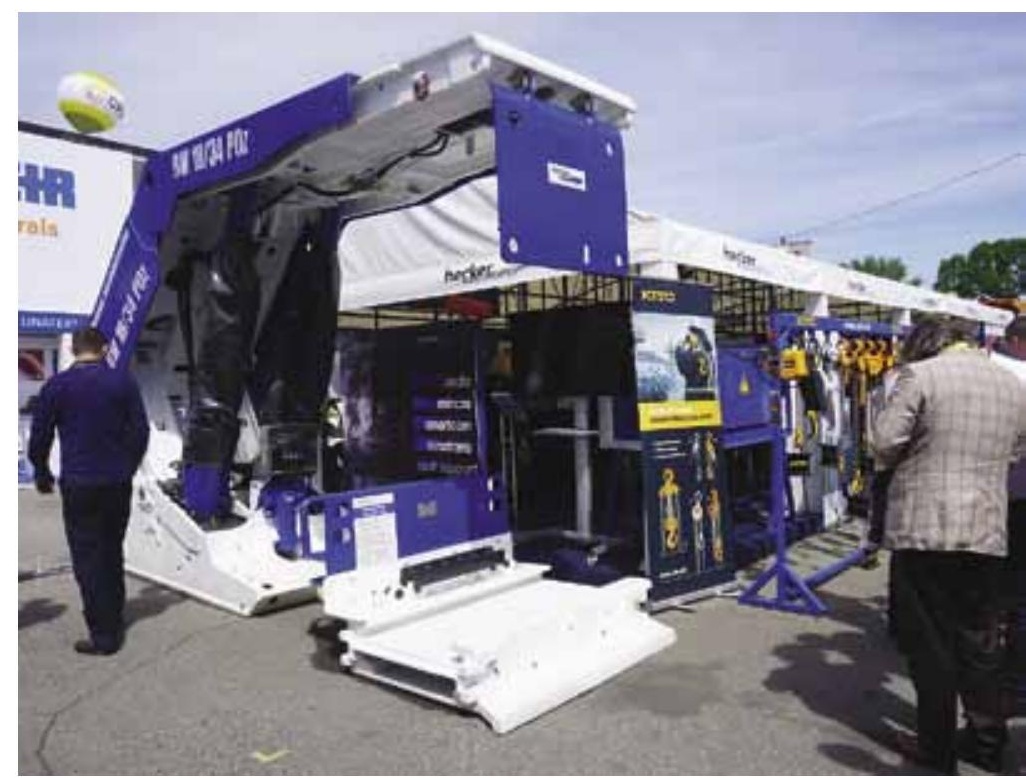

ло очередной вехой в истории Liebherr. Инновационная концепция L586 XPower сочетает в себе производительность, эффективное потребление топлива, надежность и комфорт.

Благодаря выдающимся характеристикам дизельный двигатель D9812, специально спроектированный для эксплуатации в экстремальных условиях горнодобывающей отрасли, легко адаптируется к любой норме эмиссий ОГ: оптимизированный расход топлива, EPA Tier 2 или EPA Tier 4 final. Вслед за D9812 в линейке Liebherr появятся двигатели в исполнении V16 и V20 с максимальной мощностью 2700 кВт (3620 л.с.) и 3300 кВт (4425 л.с.) соответственно.

Традиционно участие в выставке приняла компания Sandvik Mining and Rock Technology

На своем стенде разработчик представил проходческий комбайн фронтального действия МВ670-1. Модель спроектирована так, чтобы во время проведения горных выработок для упрочнения пород одновременно устанавливалась анкерная крепь.
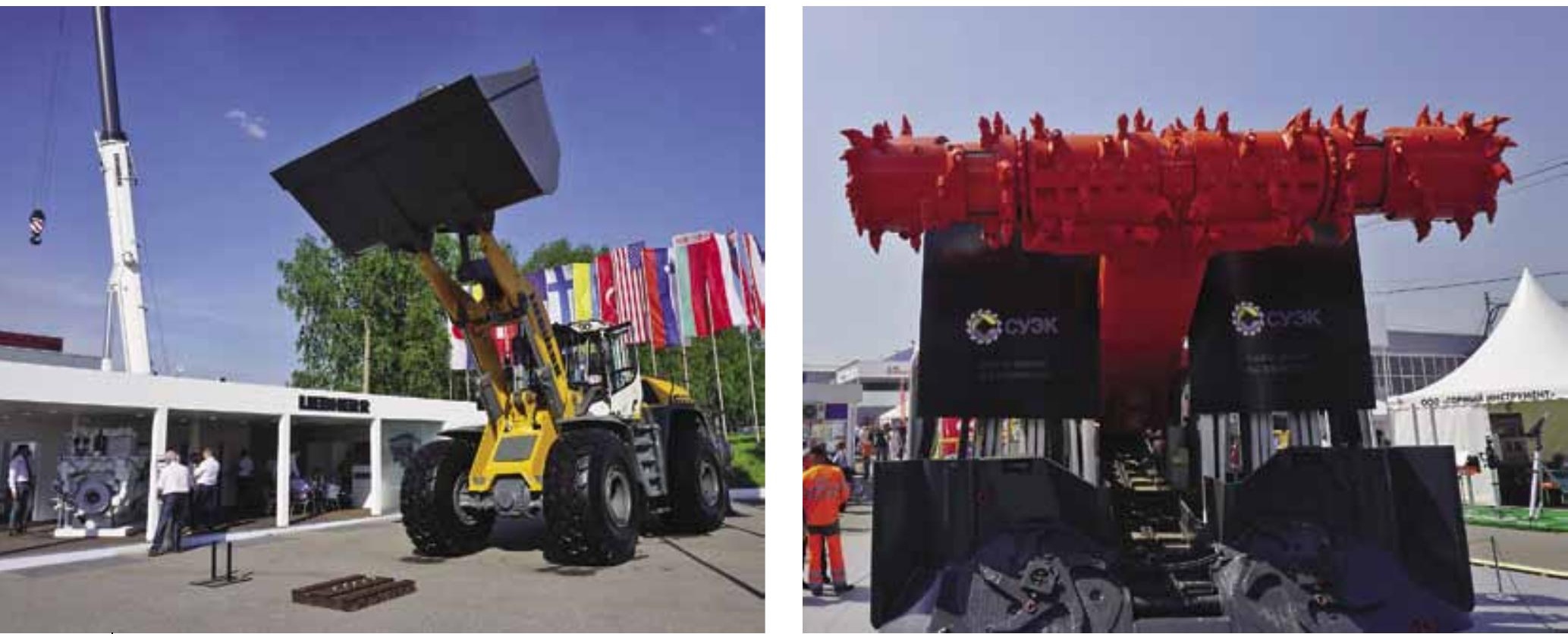
На выставке состоялась торжественная передача комбайна представителям AО «СУЭК-Кузбасс». Обладатели машины планируют эксплуатировать 105-тонный гусеничный МВ670-1 на шахте имени В.Д. Ялевского.

Максимальная ширина резания у этой модели составляет 6,2 м, а высота - до 5 м. Машина способна перемещаться со скоростью до 15 м в минуту.

Интересно будет вспомнить, что на комбайне MB670, предшественнике представляемой модели, уже дважды был поставлен подтвержденный отраслевой рекорд показателей. Впервые на шахте «Талдинская-Западная-2» в феврале 2015 г. ежемесячная проходка на МВ670 составила 1012 м подготовленной горной выработки. А в декабре 2016 г. собственное достижение было превышено, и новый показатель составил 1272 м.
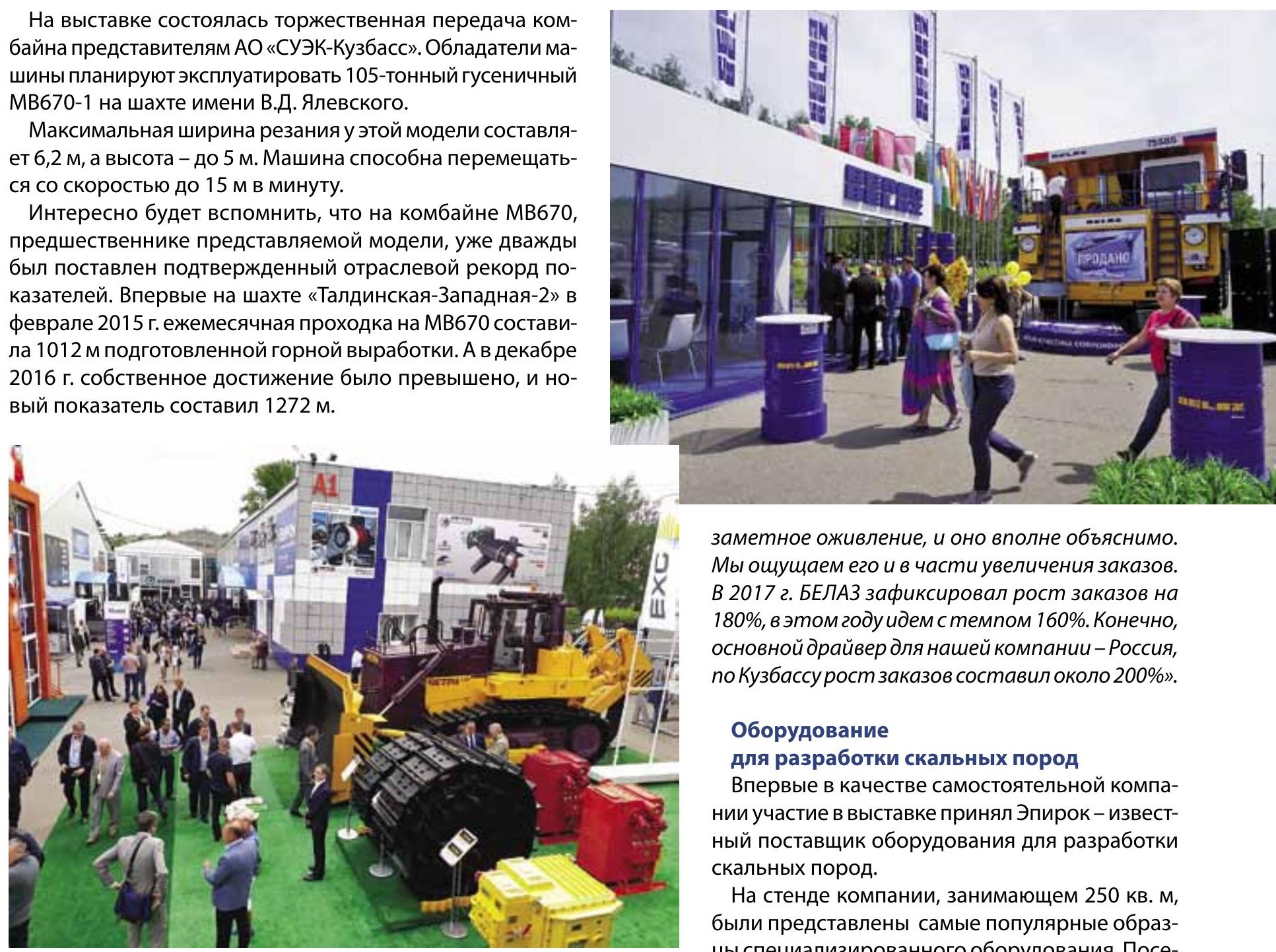

заметное оживление, и оно вполне объяснимо. Мы ошущаем его и в части увеличения заказов. В 2017 г. БЕЛАЗ зафиксировал рост заказов на 180\%, в этом году идем с темпом 160\%. Конечно, основной драйвердля нашей компании - Россия, по Кузбассу рост заказов составил около 200\%».

\section{Оборудование}

для разработки скальных пород

Впервые в качестве самостоятельной компании участие в выставке принял Эпирок - известный поставщик оборудования для разработки скальных пород.

На стенде компании, занимающем 250 кв. м, были представлены самые популярные образцы специализированного оборудования. Посе-

Самые популярные модели бульдозеров ЧЕТРА

На выставочной площадке АО «ЧЕТРА-ПМ» и официального дилера этой компании - АО «ЦГТ» представили спецтехнику и широкий ассортимент запчастей отечественного производства. В экспозицию вошли самые популярные модели бульдозеров ЧЕТРА - Т35 и Т11, а также запасные части для узлов ходовых систем и быстроизнашиваемых элементов. Представленный ассортимент запчастей подходит как для российских машин, так и для бульдозеров зарубежных производителей.

\section{Рост спроса на технику и оборудование}

Особого внимания удостоился карьерный самосвал БелАЗ-75585, завоевавший гран-при в состязаниях на лучший экспонат в номинации «Разработка и внедрение нового технологического оборудования для угольной промышленности». На выставке эта машина была продана ООО «СТК», которое бонусом к контракту получило еще и сертификат на бесплатное первое техобслуживание.

«Второй год подряд у БЕЛАЗа здесь проходит много переговоров, и они результативные, - рассказал заместитель генерального директора по качеству и стандартизации производства БЕЛАЗа Сергей Лесин. - Запланированы встречи как с партнерами, которые осуществляют поставки комплектующих, так и с нашими непосредственными потребителями. На мой взгляд, есть тители познакомились с многозадачным станком для карьеров и открытых рудников модели FlexiRoc D65 и с буровой установкой Simba S7, которая подходит для бурения глубоких скважин диаметром от 51 до 89 мм.

Также компания «Эпирок» представила вниманию посетителей гидромолот НВ7000, автоматизированная система которого сама регулирует силу и частоту ударов в зависимости от прочности породы.

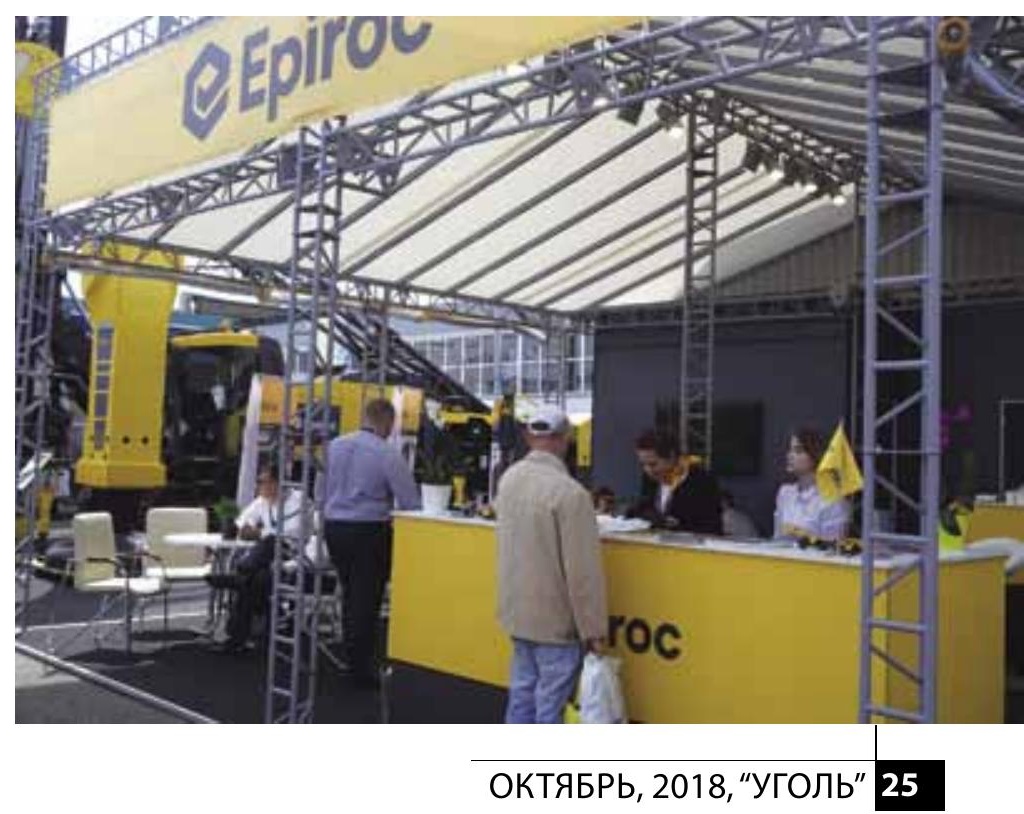




\section{Оборудование Komatsu} отлично работает в любых климатических условиях

Компания Komatsu более 30 лет поддерживает в России репутацию производителя качественной и надежной техники. Одной из причин такого признания является то, что оборудование Komatsu отлично работает в любых, в том числе и суровых, климатических условиях.

В прошлом году для расширения присутствия в горнодобывающей отрасли Komatsu осуществила поглощение компании Joy Global Inc. Компания Joy Global Inc. сохраняет свою штаб-квартиру в Милуоки, штат Висконсин, переименована в Komatsu Mining Corp. и функционирует в качестве филиала Komatsu. Компания продолжит рекламировать и осуществлять инвестиции в продукцию брендов P\&H, Јоу и Montabert.

В результате заключения сделки в коллектив компании Komatsu влились свыше 10 тыс. человек с глубокими знаниями и опытом работы в горнодобывающей отрасли, и совокупный штат сотрудников во всем мире превысил 57 тыс. человек. Нацеленная на оказание бесперебойных услуг и поставок оборудования заказчикам, компания Komatsu опирается на передовой опыт обеих компаний, согласуя их организационные и производственные структуры в интересах наилучшей поддержки заказчиков.

\section{Горношахтное оборудование из Великобритании}

Ассоциация Британских производителей горношахтного оборудования (АБМЕК) была образована более 100 лет назад и является единственной торговой ассоциацией, представляющей производителей горношахтного оборудования Соединенного Королевства.
Сегодня АВMEC объединяет более 36 компаний. Совокупный объем экспорта горношахтного оборудования и услуг этих компаний составляет приблизительно 1 млрд фунтов стерлингов. Эта группа компаний, обладающая большим опытом, проектирует и поставляет горношахтное оборудование и услуги для добычи мягких и твердых пород. Профессиональный опыт членов ассоциации включает также карьерную разработку и проходку туннелей, а также разработку таких пород, как уголь, калий, известковые породы и соль.

Компании из Великобритании хорошо зарекомендовали себя в области добычи полезных ископаемых, используя самые передовые технологии и высокие стандарты в области безопасности, обеспечивая экономически эффективные решения для самых сложных проектов. Члены ассоциации обеспечивают конкурентоспособность на мировых рынках даже в условиях жесточайшего законодательного регулирования, включая законодательство по охране окружающей среды.

АВМЕС принимает участие в выставке «Уголь России и Майнинг» с 2002 г. и считает Кузбасский регион очень важным для всех участников выставки «Уголь России и Майнинг». Компанииучастницы ассоциации представляют специализированное оборудование для подземной угледобывающей промышленности.

\section{Привет из Польши}

Несмотря на обоюдные санкции и осложнение отношений с Россией Республика Польша продолжает активный поиск деловых партнеров в России.

Многие польские фирмы сотрудничают с Кузбасским регионом на протяжении последних десятков лет. Польские предприниматели присутствуют на выставке «Уголь России и Майнинг» с самого начала, то есть вот уже 25 лет. В этом году польские фирмы на выставке в Новокузнецке представили широкий диапазон горнодобывающей техники: горные комбайны, канатные подъемные машины, промыш- 


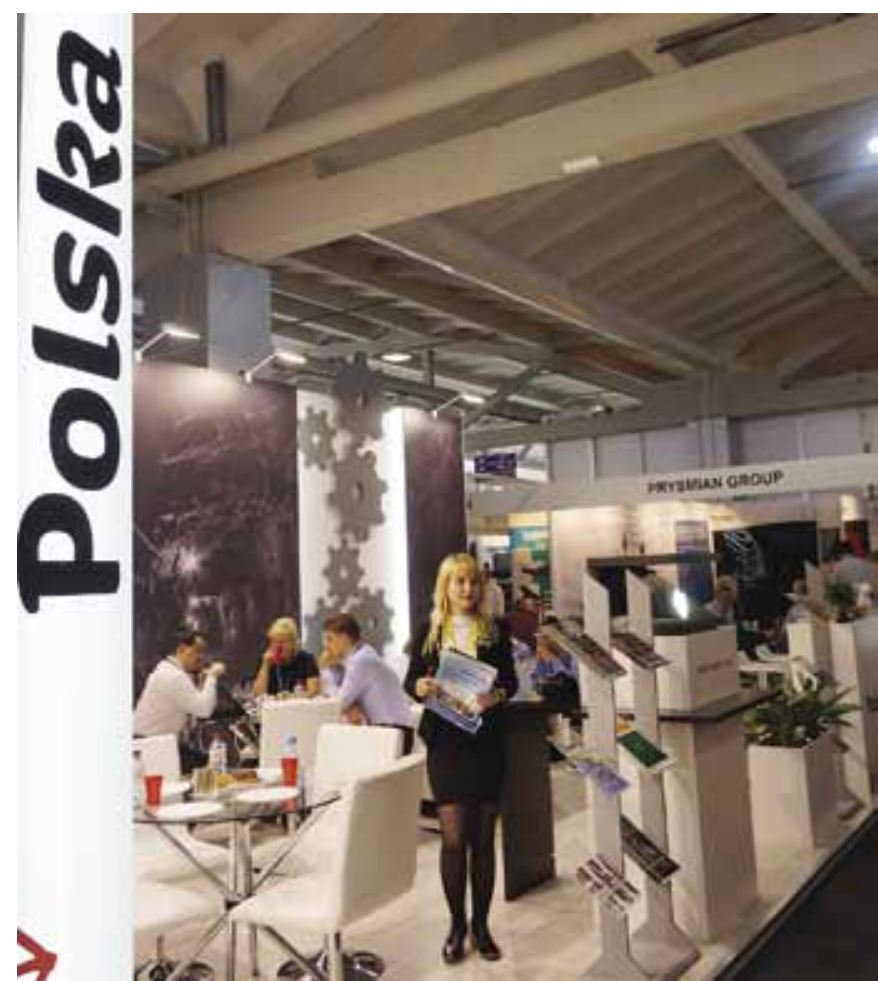

ленную автоматику, системы радиосвязи, взрывобезопасное осветительное оборудование, оборудование для обеспечения безопасности и гигиены труда и многое другое.

Вот уже более 25 лет мы встречаемся на выставке с представителями польского бизнеса и считаем, что прямое общение предоставляет самую удобную возможность обменяться опытом, познакомиться лично, а также углубляет взаимное доверие и позволяет узнать мнение российских предпринимателей о польской технике.

\section{Залог успеха}

Чешские компании - производители горношахтного оборудования уже давно успешно работают в Кузбассе. Залог успеха - четкая ориентация на потребителя, предоставление широкого спектра услуг: от производства тех-

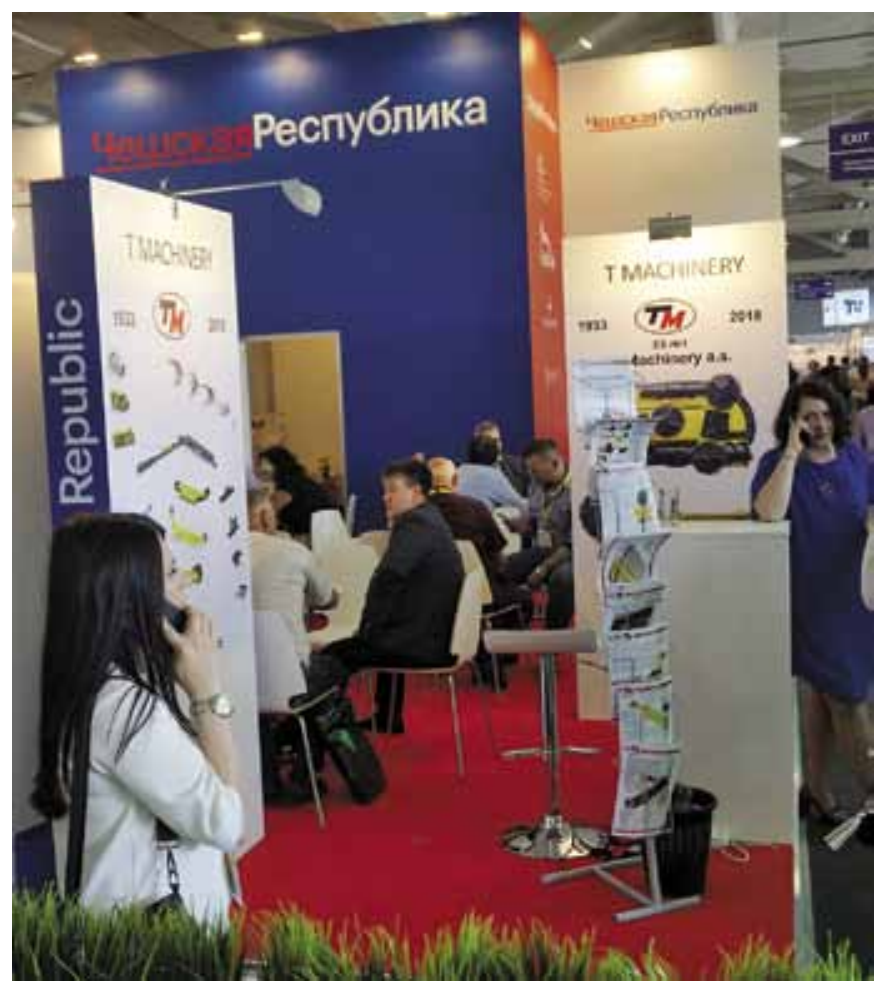

ники, с учетом специфики ее будущего места работы, до сервисного обслуживания. Чешская компания «Ferrit» на постоянной основе поставляет в Кузбасс транспортные средства для глубинных шахт, монорельсовые подвесные дороги, дизельные подвесные локомотивы, включая навесное оборудование нового поколения, напочвенные шахтные локомотивы, напочвенную дорогу, шахтные погрузчики, штрекоподдирочные машины и иную технику собственного производства. Кроме того, компания защищает интересы других чешских производителей шахтного оборудования, которые осваивают российский рынок. К настоящему времени оборудование «Ferrit» установлено на 90\% кузбасских шахт. В Кемеровской области официальным представителем «Ferrit» является ООО «Сибтранссервис» (г. Ленинск-Кузнецкий).

UDC 061.45:622.3(100) @ O.I. Glinina, 2018

TECHNICAL NEWS

ISSN 0041-5790 (Print) • ISSN 2412-8333 (Online) • Ugol' - Russian Coal Journal, 2018, № 10, pp. $22-27$

\section{Title}

XXV ANNIVERSARY INTERNATIONAL TRADE FAIR FOR COAL MINING TECHNOLOGY

PREPARATION AND MATERIALS HANDLING “UGOL ROSSII \& MINING".

IX INTERNATIONAL TRADE FAIR FOR OCCUPATIONAL HEALTH AND SAFETY IN THE MINING INDUSTRY "SAFETY \& HEALTH". IV INTERNATIONAL TRADE FAIR FOR EXPLOITATION, PROCESSING AND REFINING OF METALS AND INDUSTRIAL MINERALS "NEDRA ROSII": SUMMARY, EVENTS AND FACTS

\section{Author}

Glinina O.I. ${ }^{1}$

${ }^{1}$ Ugol' Journal Edition, LLC, Moscow, 119049, Russian Federation

\section{Authors' Information}

Glinina O.I., Mining Engineer, Leading Editor of the Russian Coal Journal (Ugol'), e-mail: ugol1925@mail.ru

\section{Abstract}

XXV Anniversary International Trade Fair for Coal Mining Technology, Preparation and Materials Handling "Ugol Rossii \& Mining", IX International Trade Fair for Occupational Health and Safety in the Mining Industry

"Safety \& Health", IV International Trade Fair for Exploitation, Processing and Refining of Metals and Industrial Minerals "Nedra Rosii" were held in expo center "Kuzbass Fair" in Novokuznetsk on June 4-8, 2018. The event organizers are the expo companies "Kuzbass Fair" and "Messe Düs- seldorf GmbH" (Germany). The exhibition "Ugol Rossii and Mining" is an international coal forum, held in Russia and No. 1 exhibition of underground coal mining technologies; and all three specialized exhibitions form a single country-wide platform for all coal and mining industries and enable familiarization with a wide spectrum of underground coal mining equipment and technologies, new products of the companies and plants - manufacturers of mining, processing, beneficiation, mechanical and electric, lighting and safety equipment. Overview of the attending companies and exhibits is provided.

Keywords

Mining Equipment, Mining Companies, Exhibition, Labour Protection, Safety. 


\section{Первая Тяжеловесная Компания укрепляет позиции в перевозках угля}

В сентябре 2018 г. Первая Тяжеловесная Компания (ПТК), занимающаяся перевозками грузов угольной и металлургической отраслей в вагонах повышенной грузоподъемности, впервые вошла в рейтинг крупнейших компаний РБК 500, заняв 365-е место.

Оператор предоставляет подвижной состав по заявкам грузовладельцев. Рост перевозок в большегрузных вагонах отражает потребность рынка именно в этом подвижном составе. ПТК увеличила перевозки металлургической продукции, угля на экспорт и для нужд энергетики даже при повышенных объемах ремонта железнодорожной ин-

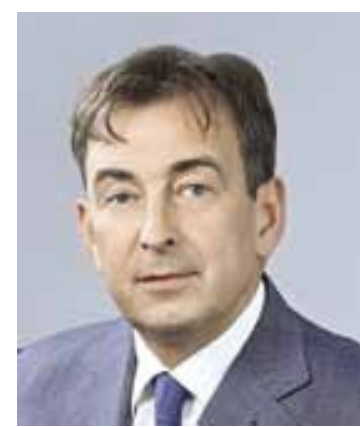

Сосипаторов B.A.

Генеральный директор ПТК даря симбиозу качества подвижного состава и технологии управления парком, созданной под руководством В. Сосипаторова, компания наращивает объем перевозок в вагонах нового поколения.

Наша справка.

Первая Тяжеловесная Компания (ПТК) крупнейший собственники оператор парка нового поколения в России. Создана в 2016 г. группой «Промышленные инвесторы» для инвестирования в проекты на рынке железнодорожных перевозок, в частности, перспективный сегмент тяжеловесного движения. Парк в управлении - более 40000 единиц.

ПТК занимает 7-е место среди крупнейших российских железнодорожных операторов в ранговом рейтинге INFOLine Rail Russia TOP по итогам первого полугодия 2018 г. и 1-еместо по производительности парка подвижного состава.

В сотрудничестве с ОАО «РЖД» компания развивает технологии тяжеловесного движения для увеличения провозной способности железнодорожной инфраструктуры за счет наращивания массы поезда и нагрузки на ось. Операторскую деятельность в рамках ПТК ведет транспортная компания «Восток1520». уверенную позицию ПТК на транспортном рынке. Благо-

\section{Исследовательский Институт Номура (Япония)}

\section{подтвердил качество природоохранных мероприятий на балкерных терминалах СУЭК на Дальнем Востоке}

\begin{abstract}
АО «Исследовательский Институт Номура Лтд.» (NRI) совместно с компанией Idemitsu Kosan Co. Ltd. nровели анализ мер и средств защиты окружающей среды, применяемых в портовых угольных терминалах $\mathrm{AO}$ «Сибирская угольная энергетическая компания» (СУЭК).
\end{abstract}

Летом 2018 г. эксперты NRI и Idemitsu посетили два терминала СУЭК: «Дальтрансуголь» (Хабаровский край, п. Ванино) и «Малый порт» (Приморский край, г. Находка). Были проведены осмотр портовых установок и оборудования, анализ осуществляемых мер по предотвращению рассеивания пыли, анализ уменьшения воздействия на окружающую среду вблизи терминалов.

Исследование подтвердило, что на территории Дальтрансуголь имеются все необходимые средства для осуществления эффективного контроля за состоянием окружающей среды и система мониторинга рассеяния угольной пыли, а также принимаются все необходимые меры по сведению рассеяния пыли к минимуму, существующему на зарубежных аналогичных предприятиях. Было подтверждено, что на терминале разрабатываются и внедряются собственные технологии и решения, которые позво- ляют эффективно обрабатывать и отправлять на экспорт уголь в сложных климатических условиях с минимальным влиянием на окружающую среду.

Эксперты также отметили, что в Малом порту, помимо стандартного ограждения, установлены дополнительные средства защиты окружающей среды (системы водяного орошения, вакуумные промышленные пылесосы) и воздействие на среду близлежащих районов сведено к минимуму.

По итогам комплексного анализа, эксперты пришли к заключению, что СУЭК прикладывает максимальные усилия по охране окружающей среды, внедряя и применяя лучшие на сегодняшний день в мировой практике меры пылеподавления, и добивается высоких результатов. Запланированная на 2019 г. установка пылезащитных экранов позволит полностью выйти на уровень лучших мировых образцов.

NRI и Idemitsu Kosan также предложили ряд мер для дальнейшего развития природоохранных технологий на терминалах СУЭК на Дальнем Востоке. Ожидается, что в результате терминалы СУЭК смогут полностью соответствовать концепции Порта нулевого выброса. 
Высокое качество и надёжность - вот вклад, вносимый нами в развитие отечественной и зарубежной горной промышленности на протяжении 110 лет существования нашего предприятия.

Эти характерные достоинства выпускаемого оборудования и богатый производственный опыт, накопленный за более чем вековую историю компании, мы готовы предложить горнодобывающим предприятиям во всём мире сегодня и в будущем!

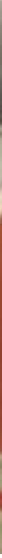

Центральная насосная станция, шахта «Августа Виктория» (RAG)

Hauhinco - Эксперты для водногидравлических систем

Hauhinco Maschinenfabrik, G. Hausherr, Jochums GmbH \& Co. KG Байсенбрухштрассе. 10 | 45549 Шпрокхёвель | Германия Тел.: +49 2324 705-0 I infolahauhinco.de I www.hauhinco.de

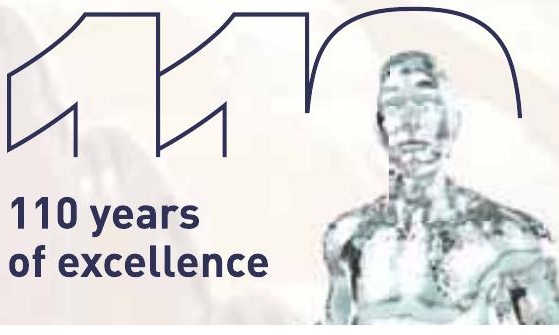

\section{На шахте «Распадская» запущена новая лава}

ПАО «Распадская» (ММВБ-РТС: RASP) 6 сентября 2018 г. сообщило о введении в эксплуатацию лавы 4-10-31 с промышленными запасами 3,5 млн т угля.

При подготовке лавы выполнен комплекс монтажнодемонтажных, горнокапитальных и проходческих работ. Проведено более 12 км горных выработок проходческими бригадами участков №№ 28 и 30.

Протяженность нового выемочного участка составляет более 3,5 км. Забой оснащен высокопроизводительным механизированным комплексом BUCYRUS, очистным комбайном JOY. Возможности комплекса позволяют ежемесячно на первом этапе (в течение 2-3 мес.) выдавать на-гора до 180 тыс. т угля, а далее - до 250-300 тыс. т.

В лаве будет трудиться один из лучших коллективов шахты «Распадская» - бригада-миллионер Рустама Муминова (добычной участок № 1).

При подготовке лавы большое внимание уделено вопросам промышленной безопасности. С поверхности на расстоянии 500-600 м по простиранию столба пробурены контрольно-профилактические скважины, выполнена обработка выработанного пространства и целиков угля аэрозолями и водными растворами антипирогенов.

Отработка новой лавы будет вестись в течение полутора лет. После обогащения на фабрике «Распадская» концентрат поставляется на металлургические и коксохимические предприятия России, Украины и Юго-Восточной Азии.

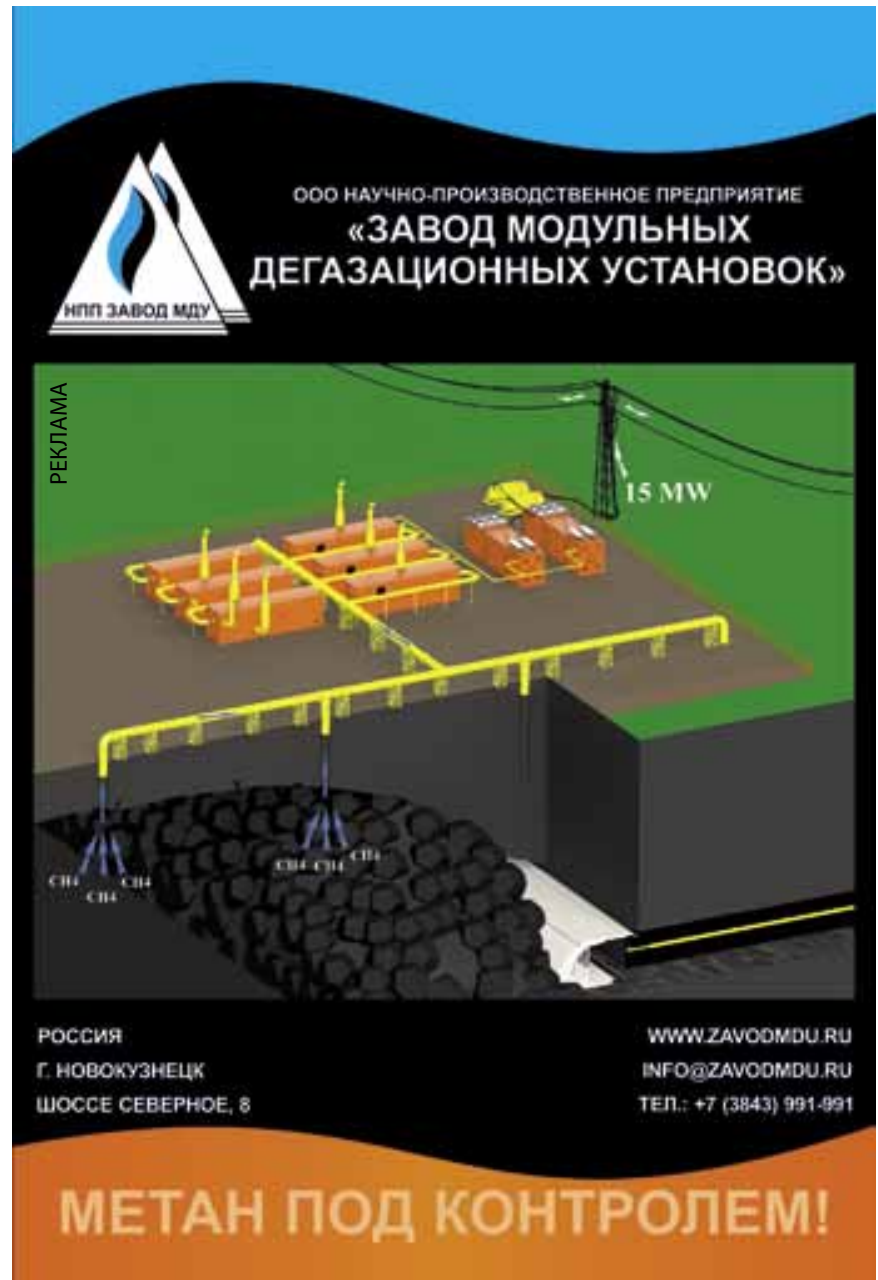

ОКТЯБРь, 2018, “УГОЛЬ" 


\section{Повышение энергетической эффективности}

\section{карьерных экскаваторов на основе модернизации электрооборудования и систем управления}

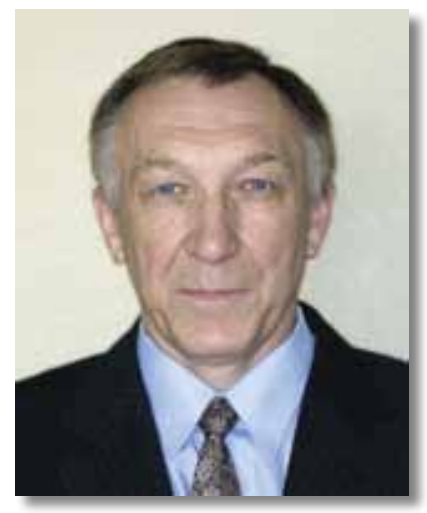

МАЛАФЕЕВ

\section{Сергей Иванович}

Доктор техн. наук,

nрофессор,

главный научный сотрудник

ООО Компания

"Объединенная Энергия», 111672, г. Москва, Россия, тел.: +7 (495) 544-46-47, e-mail:sim@jpc.ru

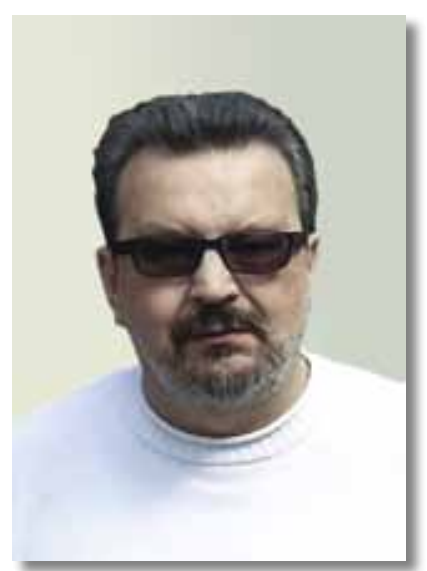

\section{СЕРЕБРЕННИКОВ}

Николай Александрович

Генеральный директор оОо Компания

«Объединенная Энергия», 111672, г. Москва, Россия, тел.: +7 (495) 558-88-18, e-mail: serebrennikov@jpc.ru
В статье приведены результаты модернизации карьерных экскаваторов в Республике Узбекистан, выполненной Компанией «Объединенная Энергия» (г. Москва). В проекте применены инновационные технические решения: электроприводы постоянного тока с транзисторными преобразователями управления; активные выпрямители для электропитания системы приводов; современный человеко-машинный интерфейс; компьютерная информационно-диагностическая система; система удаленного мониторинга. Новые экскаваторы эксплуатируются в настоящее время на добывающих предприятиях Навоийского горно-металлургического комбината (Республика Узбекистан).

Ключевые слова: экскаватор, мехатроника, двигатель, привод, контроллер.

\section{ВВЕДЕНИЕ}

В настоящее время на горных предприятиях управление энергопотреблением является важнейшим показателем эффективности их работы [1]. Мероприятия в области энергоэффективности направлены на все аспекты горных работ и добычи полезных ископаемых [2, 3]. Основным звеном в этом процессе является горная машина, характеристики которой заложены при проектировании и должны поддерживаться при эксплуатации $[4,5]$.

Экскаваторы прошлого столетия были оснащены приводами главного движения по традиционной схеме генератор - двигатель постоянного тока (Г-Д) [5]. Таким приводам присущи серьезные недостатки, влияющие на производительность экскаваторов [6]. Двойное преобразование энергии является причиной низкого КПД системы приводов [7], а электрические машины со скользящими контактами требуют постоянного обслуживания и имеют низкую надежность [8].

Перспективный вариант системы электропривода постоянного тока для экскаваторов основан на использовании широтно-импульсных преобразователей энергии, которые обеспечивают повышение КПД приводов и экскаватора в целом, существенное увеличение надежности и коэффициента мощности [8].

В 2016 г. Компания «Объединенная Энергия» выполнила модернизацию 15 карьерных экскаваторов для государственного предприятия «Навоийский горнометаллургический комбинат» (ГП НГМК) по проекту «Повышение энергоэффективности промышленныхпредприятий Республики Узбекистан (ПЭЭП)». Цель модернизации - снижение электропотребления и потерь электроэнергии в питающих сетях, повышение качества работы приводов, увеличение надежности оборудования путем замены генераторной группы транзисторными преобразователями энергии с современной системой управления [9].

В настоящей работе представлено краткое описание результатов реализации указанного проекта модернизации карьерных экскаваторов ЭКГ-5, ЭКГ-10 и ЭКГ-15.

\section{ИННОВАЦИОННЫЕ РЕШЕНИЯ}

\section{В ПРОЕКТЕ МОДЕРНИЗАЦИИ ЭКСКАВАТОРОВ}

Проект модернизации экскаваторов предусматривал полную замену физически и морально устаревшего оборудования и применение современных компонентов управления, использующих достижения в области электропривода, 
силовой преобразовательной техники и информационных технологий [10, $11,12]$. В экскаваторах использованы:

- ячейка высоковольтного ввода с системой защит оборудования и модулем учета расхода электроэнергии;

- транзисторные широтно-импульсные преобразователи для управления двигателями постоянного тока;

- активные выпрямители для электропитания системы приводов;

- стабилизаторы трехфазного переменного напряжениядля электропитания вспомогательного оборудования;

- современный человеко-машинный интерфейс, компьютерная информационно-диагностическая система и система удаленного мониторинга.

Мехатронный комплекс реализован на основе типовой функциональной схемы, разработанной Компанией «Объединенная Энергия» для карьерных экскаваторов [8]. Первый приоритет в этом комплексе имеет система электропитания, обеспечивающая его эффективную работу во всех режимах.

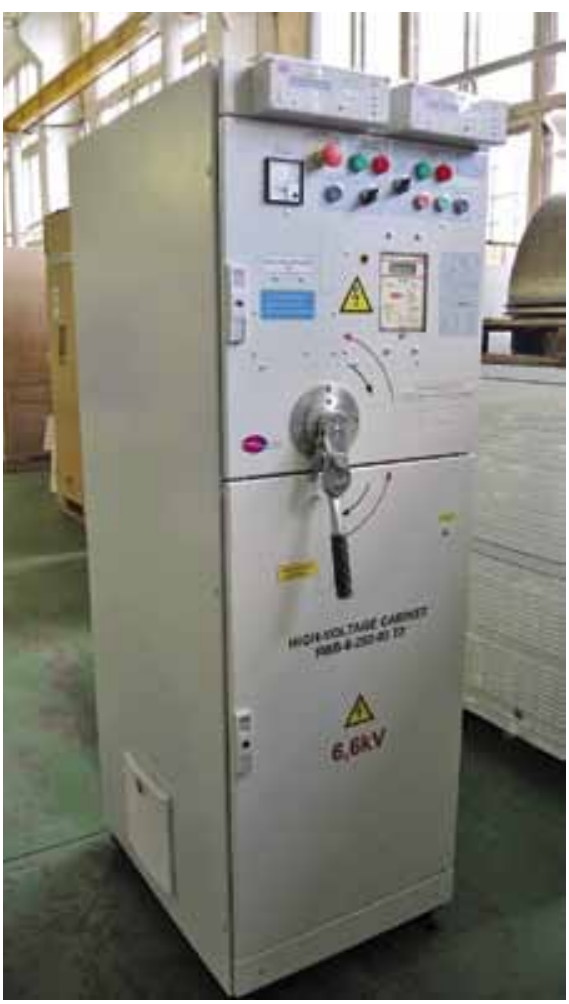

Pис. 1. Ячейка высоковольтного ввода

ках приводных двигателей с помощью мостовых транзисторных преобразователей. Питание преобразователей осуществляется от общего звена постоянного тока, напряжение которого стабилизируется активными выпрямителями. От общего звена постоянного тока питаются: реверсивный мостовой транзисторный преобразователь подъема, преобразователь напора, преобразователь поворота и преобразователь хода, которые работают в режиме ведущий - ведомый.

Активные выпрямители обеспечивают высокий уровень электромагнитной совместимости экскаватора и питающей электрической сети. Коэффициент мощности поддерживается постоянным и равным 1, коэффициент искажений потребляемого тока не превышает 5\% [8].

Внешний вид шкафов управления показан на рис. 2.

Стабилизатор переменного напряжения. Для потребителей собственных нужд применены специальные мощные (120 кВт) трехфазные ста-

Ячейка высоковольтного ввода ЯВВ-6-250-УХЛ2 (рис. 1) для экскаваторов имеет виброустойчивое исполнение с односторонним обслуживанием, содержит два разъединителя для подключения силового трансформатора электропитания главных приводов и вспомогательного электрооборудования.

Устройство полностью отвечает всем требованиям РД 05-334-99, утвержденным Госгортехнадзором России. Повышенная безопасность эксплуатации ячейки обеспечивается взаимной блокировкой разъединителей, исключением доступа в отсек при включенном разъединителе, индикацией высокого напряжения на вводе и состояния вакуумного контактора. Устройство содержит полный комплект специальных микроконтроллерных защит с функцией тестирования и индикацией причины срабатывания защитного отключения, компоненты местного и дистанционного управления, контроллер регистрации аварийных событий. Ячейка оснащена многофункциональными приборами учета расхода электроэнергии типа «Знак+». Ресурс коммутационной аппаратуры ячейки составляет 750000 циклов.

Электроприводы главного движения экскаваторов (напора, подъема и поворота), а также электропривод хода выполнены по системе «транзисторный широтно-импульсный преобразователь - двигатель постоянного тока». Для электропитания приводов используется локальная сеть постоянного тока, организованная с использованием группы активных выпрямителей $A B$ и емкостным накопителем энергии. Выходное напряжение в локальной сети постоянного тока поддерживается постоянным с помощью регулятора напряжения, который также обеспечивает управляемый «мягкий» заряд конденсаторов в звене постоянного тока при включении системы. Регулирование скорости и момента электроприводов экскаваторов происходит путем изменения частоты и напряжения на якорных обмот- билизаторы. Цепи управления получают питание от отдельного преобразователя с использованием дополнительного емкостного накопителя энергии, благодаря чему обеспечивается сохранение работоспособности системы управления при отключении силовой сети. Преобразователь реализует несколько алгоритмов регулирования трехфазного напряжения, в том числе «мягкое» включение нагрузки. В результате применения стабилизатора повышаются на-

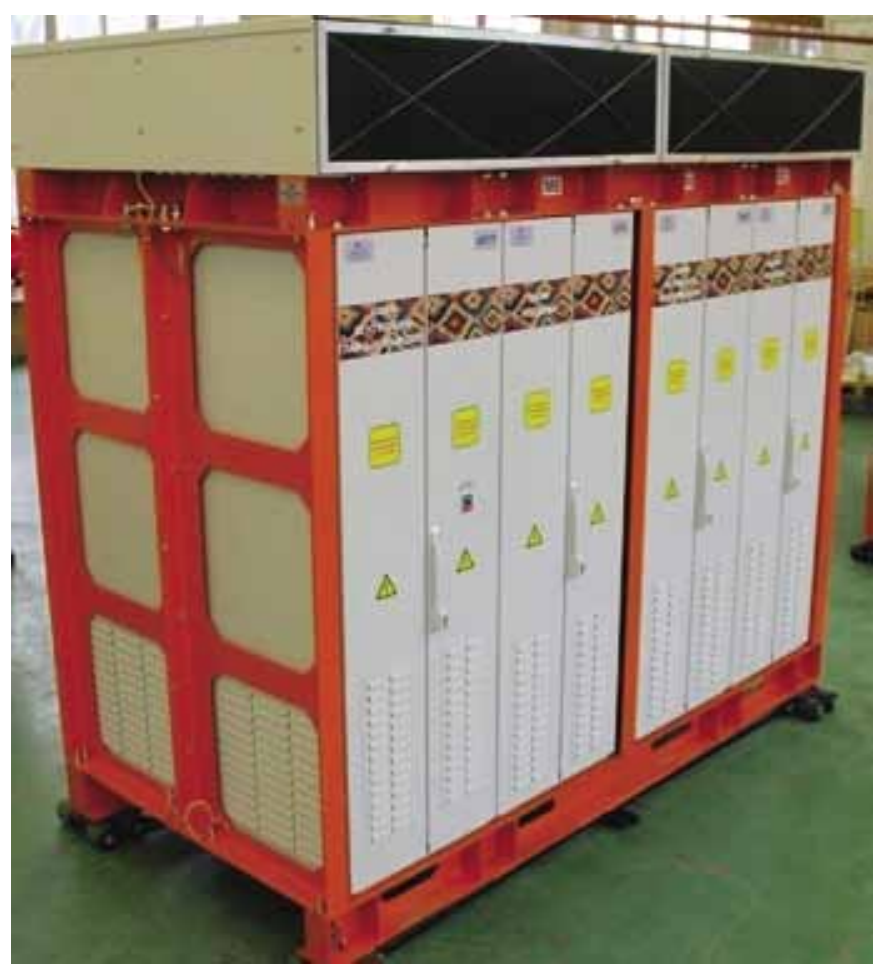

Рис. 2. Внешний вид шкафов аппаратуры управления главными приводами 
дежность работы и ресурс электрооборудования; повышается качество электрической энергии в системе электропитания собственных нужд экскаватора; обеспечивается гарантированное электропитание ответственных систем управления при отключении питающей сети; уменьшается количество силовых компонентов в системе электропитания (трансформаторов, коммутационных аппаратов, кабелей); снижается электропотребление за счет стабилизации напряжения в рабочем режиме и регулирования напряжения при отключенных цепях; снижается пожарная опасность оборудования.

Тиристорные коммутационные устройства применены вместо традиционных контакторов и пускателей для управления компонентами вспомогательного оборудования экскаватора и обеспечивают повышенную надежность аппаратуры в условиях вибраций и действия пыли.

Силовые кабели для электропитания оборудования типа H07RN-F Premium 4G4 (Германия) имеют диапазон рабочих температур от $-50^{\circ} \mathrm{C}$ до $+90^{\circ} \mathrm{C}$. Безгалогенная резиновая компаундная изоляция кабеля не поддерживает горение и обеспечивает повышенную пожаробезопасность.

Информационно-диагностическая система экскаватора реализована на основе стандартных технических средств автоматизации и типового и специализированного программного обеспечения [13]. Оборудование ИДС включает: монитор оператора (рис. 3); главный компьютер; блок бесперебойного питания; комплект датчиков параметров технологического процесса; концентраторы данных; локальную компьютерную сеть; модемы [14].

Данные, поступающие из ИДС и преобразованные по специальным алгоритмам, выводятся на монитор и сохраняются на сервере. Важная для оценки работы информация запоминается в программных модулях и обрабатывается с целью анализа эффективности работы экскаватора, оценивания его надежности [13]. В процессе работы производится регистрация основных процессов, изменения состо- яния оборудования, протоколов аварий и др. Данные хранятся на сервере и передаются в центр. Срок хранения записей зависит от вида процесса и типа оборудования. Данные, получаемые с машины, используются разработчиком оборудования для уточнения моделей при проектировании новых машин и коррекции параметров машин, находящихся в эксплуатации.

Современные технические средства измерений и обработки данных позволяют организовать обратную связь от эксплуатации к проектированию, при этом сбор данных осуществляется средствами информационно-диагностических систем (ИДС) промышленных автоматизированных объектов, после чего производятся передача данных ИДС на предприятие-изготовитель и их автоматизированный анализ. При этом реализуется технология получения проектных данных непосредственно с действующего объекта [14].

Основным компонентом взаимодействия персонала и системы является дружественный и удобный в навигации графический интерфейс пользователя. С помощью сенсорного экрана, сочетающего в себе одновременно и аппаратную, и программную части, происходит управление системами экскаватора [14]. Обслуживающий персонал имеет возможность отслеживать все основные показатели работы экскаватора, состояние оборудования, характеристики питающей сети, данные о неисправностях на экскаваторе.

Телекоммуникационная система обеспечивает удаленное наблюдение и управление через сеть Интернет с любого персонального компьютера или мобильного устройства (телефона, планшетного компьютера) при помощи программы удаленного администрирования, установленной на компьютере-мониторе ИДС. Программа позволяет наблюдать процессы и управлять экранами системы, а также имеет возможность пересылки файлов-архивов на компьютер или мобильное устройство удаленного пользователя. Предусмотрена дистанционная настройка приводов, активных выпрямителей и другого оборудования [14].

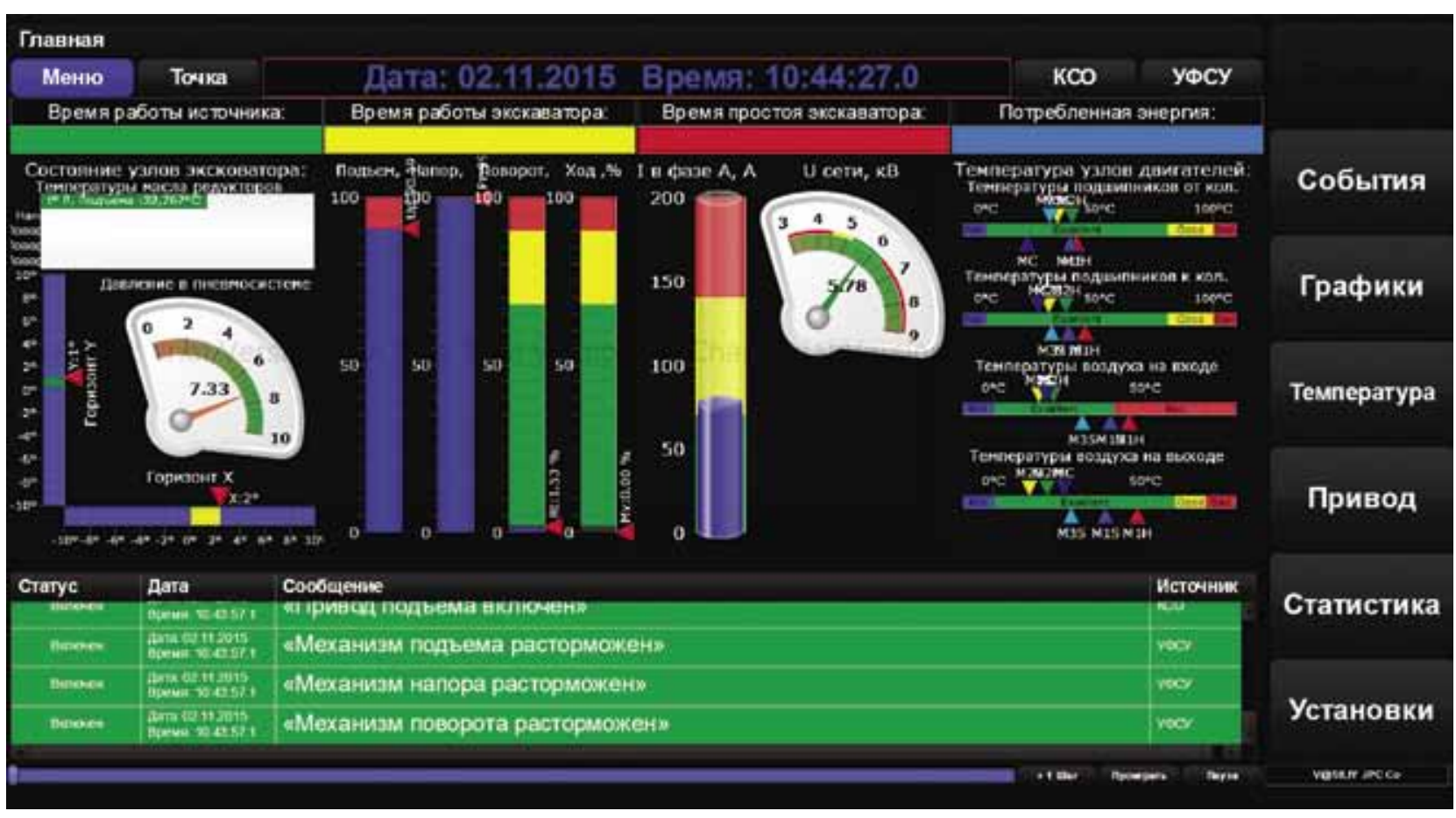

Puc. 3. Главный экран монитора оператора 


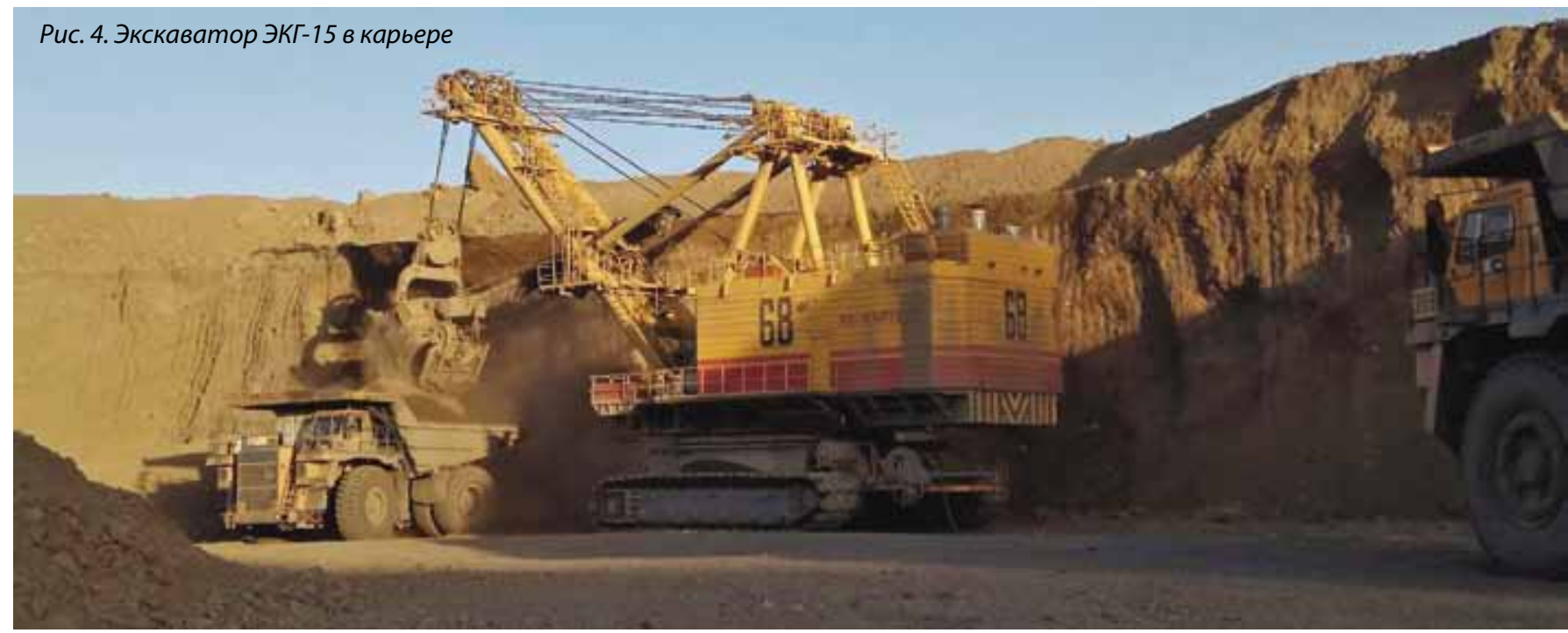

\section{РЕЗУЛЬТАТЫ РЕАЛИЗАЦИИ}

\section{ПРОЕКТА МОДЕРНИЗАЦИИ ЭКСКАВАТОРОВ}

Модернизированные экскаваторы ЭКГ-5, ЭКГ-10 и ЭКГ-15, соответственно 3, 7 и 5 машин, введены в эксплуатацию на добывающих предприятиях ГП НГМК во второй половине 2017 г. - начале 2018 г. Работа экскаваторов подтвердила соответствие основных показателей работы расчетным и заявленным в проектной документации значениям [9]. По данным службы эксплуатации определены следующие основные характеристики машин:

- время цикла - 27-29 с;

- удельная энергоемкость экскавации - 0,21 кВТ.ч/M

- коэффициент мощности - не менее 0,95;

- коэффициент технической готовности - 0,96.

Потребление электроэнергии сокращено на $40 \%$ за счет увеличения КПД приводов главного движения и электрооборудования собственных нужд и усовершенствованных алгоритмов энергосбережения в различных режимах. За счет повышения коэффициента мощности до $\cos \varphi \approx 0,98$ снижены потери энергии в питающих сетях в 6-8 раз. Уменьшена чувствительность качества работы экскаватора к отклонениям и колебаниям напряжения в питающей сети, обеспечена устойчивая работа приводов с номинальными параметрами при длительных отклонениях напряжения в питающей сети от +15 до - $20 \%$ номинального значения.Увеличена надежность работы вспомогательного электрооборудования.

На рис. 4 показан модернизированный экскаватор ЭКГ-15, работающий в карьере.

\section{ЗАКЛЮЧЕНИЕ}

Мехатронные системы главного движения экскаваторов реализованы на основе современных достижений силовой электроники, микропроцессорной техники и телекоммуникаций. Интеллектуальное управление движением механизмов обеспечивает высокие энергетические и динамические характеристики и индивидуальную коррекцию приводов, исключающую удары и выходы в аварийные зоны.

Применение современных транзисторных преобразователей для управления двигателями постоянного тока позволило уменьшить электропотребление по сравнению с традиционными экскаваторами с приводами по системе генератор - двигатель на 20-30\% и снизить удельную энер- гоемкость экскавации. Коэффициент мощности экскаватора во всех режимах работы поддерживается постоянным и равным заданному значению, за счет чего обеспечивается оптимальная электромагнитная совместимость экскаватора и питающей электрической сети.

Новые информационные системы экскаваторов обеспечивают полный контроль всех основных рабочих параметров, нагрузок на рабочие органы, состояния всех компонентов оборудования, анализ и представление в табличном и графическом виде данных по основным технологическим показателям работы экскаватора (объем отгруженной горной массы, время полезной работы, расход электроэнергии и прочее). Информационные системы содержат модуль удаленного мониторинга. Данные мониторинга на экскаваторе передаются через Интернет на главный сервер интернет-мониторинга. Система удаленного мониторинга экскаватора действует как Windows-приложение и полностью повторяет интерфейс реальной системы, непосредственно работающей на машине. Информационная телекоммуникационная система удаленного наблюдения за работой экскаватора и всех его компонентов обеспечивает создание из отдельных фрагментов единых информационныхполей для машинистов, работников добывающихпредприятий и изготовителей экскаваторов.

Разработанные системы управления экскаваторами гарантируют высокое качество результатов работы. Системы управления техникой кардинально меняют технологию производства горных работ, позволяя достичь принципиально новых рубежей качества и точности реализации проектов со значительной экономией времени и средств.

\section{Список литературы}

1. Awuah-Offei K. (Editor). Energy efficiency in the Minerals Industry: Best Practices and Research Directions, Springer, 2017.333 p. ISBN 978-3-319-54199-0. doi: 10.1007/978-3-31954199-0.

2. Levesque M., Millar D., Paraszczak J. Energy and mining the home truths // Journal of Cleaner Production. 2014. doi: 10.1016/j.jclepro.2013.12.088.

3. Об энергосбережении и повышении энергетической эффективности в АК «АЛРОСА» (ПАО) / Н.А. Соловьева, А.И. Крашенинников, И.В.Зырянов, А.В. Рыбников // Горное оборудование и электромеханика. 2016. № 2. С. 16-19. 
4. Electric or Hydraulic Energy Recovery Systems in a Reach Truck - A Comparison / T. Minav, H. Hänninen, A. Sinkkonen, L. Laurila, J. Pyrhönen // Journal of Mechanical Engineering. 2014. Vol. 60. N 4, Pp. 232-240. doi: 10.5545/sv-jme.2013.1581.

5. Bise C.J. Modern American Coal Mining: Methods and Applications. Published by SME (Society for Mining, Metallurgy and Exploration, Inc.). 2013. 576 p.

6. Малафеев С.И., Малафеев С.С., Серебренников Н.А. Компьютерное моделирование мехатронных систем одноковшовых экскаваторов // Горное оборудование и электромеханика. 2011. № 5. С. 24-29.

7. Casson M. Dragline Retrofit for AC Motion Power / «SYMPHOS 2013». $2^{\text {nd }}$ International Symposium on Innovation and Technology in the Phosphate //Procedia Engineering. 2014. N 83. Pp. 86-89. doi: 10.1016/j.proeng.2014.09.017.

8. Malafeev S.I., Novgorodov A.A. Design and implementation of electric drives and control systems for mining excavators // Russian Electrical Engineering. October 2016. Vol. 87. Issue 10. Pp. 560-565. doi: 10.3103/S1068371216100035.
9. Демина Г.А. Горная техника Группы Газпромбанка:Уралмашзавода и ИЗ-КАРТЭКС - на горнодобывающих предприятиях Узбекистана // Горная промышленность. 2017. № 4. С. 40-42.

10. Владимиров Д.Я. Интеллектуальный карьер: Эволюция или революция? // Горный информационно-аналитический бюллетень. 2015. Отдельный выпуск. № 45-1. С. 77-82.

11. Курцев Б.В., Жданов А.В. Методологические аспекты создания единого информационного пространства на горнодобывающемпредприятии // Горныйжурнал. 2014. № 4. С. 29-31.

12. Агеев С.С., Реймер А.В. Горное оборудование Уралмашзавода. Екатеринбург:ООО «Форт Диалог-Исеть», 2016.120 с.

13. Шпрехер Д.М., Бабокин Г.И. Система технического диагностирования электромеханических комплексов // Контроль. Диагностика. 2016. № 3. С. 52-56.

14. Малафеев С.И., Коняшин В.И. Организация мониторинга карьерных экскаваторов // Наукоемкие технологии разработки и использования минеральных ресурсов. 2017. № 3. С. 201-206.

UDC 621.315.62:621.879.3 @ S.I. Malafeev, N.A. Serebrennikov, 2018

COAL MINING EQUIPMENT

ISSN 0041-5790 (Print) • ISSN 2412-8333 (Online) • Ugol' - Russian Coal Journal, 2018, № 10, Pp. 30-34

\section{Title}

\section{INCREASING ENERGY EFFICIENCY OF MINING EXCAVATORS THROUGH UPGRADE OF ELECTRICAL EQUIPMENT AND CONTROL SYSTEMS}

DOI: http://dx.doi.org/10.18796/0041-5790-2018-10-30-34

\section{Authors}

Malafeev S.I. ${ }^{1}$, Serebrennikov N.A. ${ }^{1}$

1 "Joint Power Co" LLC, Moscow, 111672, Russian Federation

\section{Authors' Information}

Malafeev S.I., Doctor of Engineering Sciences, Professor, Chief Scientific Officer, tel.: +7 (495) 544-46-47, e-mail: sim@jpc.ru

Serebrennikov N.A., General Director, tel.: +7 (495) 558-88-18, e-mail: serebrennikov@jpc.ru

\begin{abstract}
The paper presents the results of modernization of mining excavators in the Republic of Uzbekistan carried out by the "Joint Power Co" LLC (Moscow). The project uses innovative technical solutions: DC electric drives with transistor control converters; active rectifiers for power supply of the drive system; modern man-machine interface; computer information-diagnostic system; remote monitoring system. New excavators are currently in operation at the mining enterprises of the Navoi Mining and Metallurgical Combine (Republic of Uzbekistan).
\end{abstract}

\section{Keywords}

Excavator, Mechatronics, Motor, Drive, Controller.

\section{References}

1. Awuah-Offei K. (Editor). Energy efficiency in the Minerals Industry: Best Practices and Research Directions, Springer, 2017, 333 p. ISBN 978-3-319-54199-0. doi: 10.1007/978-3-319-54199-0.

2. Levesque M., Millar D. \& Paraszczak J. Energy and mining - the home truths. Journal of Cleaner Production, 2014. doi: dx.doi.org/10.1016/j. jclepro.2013.12.08810.1016/j.jclepro.2013.12.088.

3. Solovyova N.A., Krasheninnikov A.I., Zyryanov I.V. \& Rybnikov A.V. Ob energosberezhenii i povyshenii energeticheskoi effektivnosti v AK «ALROSA» (PAO) [On energy saving and energy efficiency increase in ALROSA (PJSC)]. Gornoe oborudovanie i elektromekhanika - Mining equipment and electromechanics, 2016, No. 2. Pp. 16-19.

4. Minav T., Hänninen H., Sinkkonen A., Laurila L. \& Pyrhönen J. Electric or Hydraulic Energy Recovery Systems in a Reach Truck - A Comparison. Journal of Mechanical Engineering, 2014, Vol. 60, No. 4, Pp. 232-240. doi: 10.5545/svjme.2013.1581.
5. Bise C.J. Modern American Coal Mining: Methods and Applications. Published by SME (Society for Mining, Metallurgy and Exploration, Inc.), 2013, 576 p. 6. Malafeev S.I., Malafeev S.S. \& Serebrennikov N.A. Komp'yuternoe modelirovanie mekhatronnykh sistem odnokovshovykh ekskavatorov [Computer simulation of mechatronic systems of single bucket excavators]. Gornoe oborudovanie i elektromekhanika-Mining equipment and electromechanics, 2011, No.5, Pp. 24-29. 7. Casson M. Dragline Retrofit for AC Motion Power / "SYMPHOS 2013". 2nd International Symposium on Innovation and Technology in the Phosphate. Procedia Engineering, 2014, No. 83, Pp. 86-89. doi: 10.1016/j.proeng.2014.09.017. 8. Malafeev S.I., Novgorodov A.A. Design and implementation of electric drives and control systems for mining excavators. Russian Electrical Engineering, October 2016, Vol. 87, Issue 10, Pp. 560-565. doi: 10.3103/S1068371216100035. 9. Demina G.A. Gornaya tekhnika Gruppy Gazprombanka: Uralmashzavoda i IZ-KARTEKS - na gornodobyvayushchikh predpriyatiyakh Uzbekistana [Mining equipment of Gazprombank Group: Uralmashzavod and IZ-KARTEX - at mining enterprises of Uzbekistan]. Gornaya Promyshlennost' - Mining Industry, 2017, No. 4, Pp. 40-42.

10. Vladimirov D.Ya. Intellektual'nyi kar'er: Evolyutsiya ili revolyutsiya? [Intelligent quarry: Evolution or revolution?]. Gornyy Informatsionno-Analiticheskiy Byulleten' - Mining Information and Analytical Bulletin, 2015, Separate issue, No. 45-1, Pp. 77-82.

11. Kurtsev B.V. \& Zhdanov A.V. Metodologicheskie aspekty sozdaniya edinogo informatsionnogo prostranstva na gornodobyvayushchem predpriyatii [Methodological aspects of creating a single information space in a mining enterprise]. Gornyy Zhurnal - Mining Journal, 2014, No. 4, Pp. 29-31.

12. Ageev S.S. \& Reymer A.V. Gornoe oborudovanie Uralmashzavoda [Mining equipment of Uralmashzavod]. Ekaterinburg, "Fort Dialogue-Iset" LLC, 2016, $120 \mathrm{p}$.

13. Shpreher D.M. \& Babokin G.I. Sistema tekhnicheskogo diagnostirovaniya elektromekhanicheskikh kompleksov [System of technical diagnostics of electromechanical complexes]. Kontrol.' Diagnostika - Control. Diagnostics, 2016, No. 3, Pp. 52-56.

14. Malafeev S.I. \& Konyashin V.I. Organizatsiya monitoringa kar'ernykh ekskavatorov [Organization of monitoring of mining excavators]. Naukoemkie tekhnologii razrabotki i ispolzovaniya mineralnykh resursov - High technology of development and use of mineral resources, 2017, No. 3, Pp. 201-206. 


\title{
Обоснование способа электромагнитного излучения
}

\author{
при инициировании и распространении \\ взрыва метана и угольной пыли \\ в шахтной атмосфере
}

DOI: http://dx.doi.org/10.18796/0041-5790-2018-10-36-41

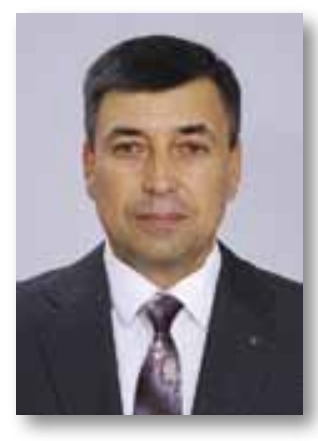

КОЛЕСНИЧЕНКО ИГорь Евгеньевич

Доктор техн. наук, профессор, заведующий кафедрой «Строительство и техносрерная безопасность», заместитель директора по учебной работе Шахтинского института (филиала) ФГБОУ ВПО «Южно-Российский государственный политехнический университет (НПИ) имени М.И. Платова», 346527, 2. Шахты, Россия, тел.: +7 (8636) 22-75-49, e-mail: kolesnichenko-igor@rambler.ru

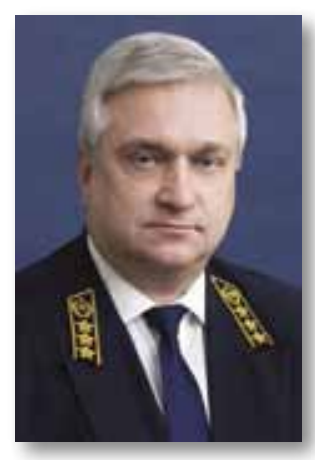

\author{
АРТЕМЬЕВ Владимир Борисович \\ Доктор техн. наук, \\ заместитель генерального директора- \\ директор по производственным \\ операчиям $A O$ «СУЭК», \\ профессор кафедры БЭГП \\ Горного института НИТУ «МИСИС», \\ 115054, г. Москва, Россия, \\ e-mail:pr_artem@suek.ru
}

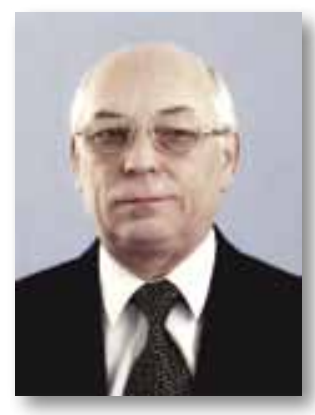

КОЛЕСНИЧЕНКО Евгений Александрович Доктор техн. наук, профессор, профессор кафедры «Строительство и техносферная безопасность» Шахтинского института (филиала) ФГБОУ ВПО «ЮРГПУ (НПИ) им. М.И. Платова», 346527, 2. Шахmы, Россия, e-mail:kolesnichenko-2718@rambler.ru

Статья посвящена проблемам предотвращения взрывов метана и угольной пыли. Представлен анализ концепций о физической природе тепловой энергии и способах распространения в горючей среде. Показан объемный принцип распределения молекул метана и угольной пыли в шахтной атмосфере. Приведено массовое содержание химических элементов углерода и водорода в угольных пластах на шахтах АО «СУЭК». Приведены вероятные схемы макромолекул угля. Обоснован электромагнитный принцип переноса тепловой энергии меж- ду молекулами горючих веществ. Показано, что при возгорании молекулы всех внешних источников энергии начинают испускать электромагнитные волны (фотоны) в горючую среду. Приведено описание физического механизма образования и переноса фотонов энергии. Обоснованы два типа передачи фотонами тепловой энергии. Описан процесс переноса энергии в горючей среде, приведено физическое обоснование воспроизводства тепловой энергии при образовании молекулы двуокиси углерода и двухмолекул воды. Описан процесс распространения световой границы (пламени), горения и взрыва метана и угольной пыли.

Ключевые слова: молекулы, электромагнитные волны, фотон, метан, угольная пыль, горная выработка, кинетическая энергия, электроны, энергетические уровни, передача энергии, электронные орбители, скорость распространения, горение, взрыв.

\section{АКТУАЛЬНОСТЬ}

Наименее изученной проблемой при решении практических вопросов предотвращения взрыва метана и угольной пыли является обоснование способа распространения энергии между молекулами и частицами угольной пыли, которые находятся в массе негорючих молекул азота и кислорода шахтной атмосферы. При разрушении массива угольного пласта выделяется газ метан. Угольная пыль дисперсного состава образуется при разрушении массива резцами очистных и проходческих комбайнов. В местах интенсивного загазирования и запыления в шахтной атмосфере может образоваться опасная концентрация метана и угольной пыли. Опыт показывает, что при аварийных ситуациях с образованием мощных локальных источников тепловой энергии горючие вещества вступают в реакцию с кислородом воздуха, которая характеризуется как возгорание с последующим выгоранием или взрывом в области распространения горючих веществ. Такие взрывы на шахтах России и за рубежом известны давно, последствиями их являются значительные материальные и людские потери. 
Для решения проблемы предотвращения взрывов сучастием метана и угольной пыли было выполнено значительное количество исследований. Разрабатывались способы уменьшения объемов метана и угольной пыли, поступающих в шахтную атмосферу, и совершенствования вентиляции горных выработок. Изучались процессы горения и взрыва метана и угольной пыли. Были сформулированы основные положения теории горения и взрыва. Однако многие термины и положения теории не дают собственно представления о процессах горения и взрыва, способахпереноса тепловой энергии между горючими веществами, которые окружены нейтральными негорючими молекулами азота и кислорода воздуха. Отсутствуют условия возникновения светового излучения при горении. Авторы предлагают на основе квантовой электродинамики новый метод описания процесса горения и взрыва метана и витающих пылевых частиц в воздухе в горных выработках.

Цель работы - на основе изучения структурноэнергетических характеристик молекул и атомов метана и угольной пыли обосновать закономерности переноса тепловой энергии электромагнитными волнами (фотонами) между горючими веществами, передачей кинетической энергии и электромагнитными волнами при столкновении нейтрально-негорючих молекул шахтного воздуха в горючей среде горной выработки.

\section{ОБСУЖДЕНИЕ ПРЕДЛАГАЕМОЙ КОНЦЕПЦИИ}

Исследованиями российских и зарубежных ученых [1, 2, 3, 4, 5, 6] установлены закономерности выделения метан, взрывоопасные параметры угольной пыли и метана. Основные принципы концепции возникновения и развития процессов горения горючих веществ были сформулированы в работах академиков Н.Н. Семенова [7], Я.Б. Зельдовича [8], Б. Льюиса и Г. Эльбе [9] и других. Продолжающиеся исследования $[10,11,12]$ процессов возгорания и взрыва угольной пыли носят экспериментальный характер с набором различных фактических знаний или виртуального математического моделирования. Однако эти исследования обосновывают концепцию происходящих реакций по результатам происходящих макропроцессов. В результате необоснованными остаются сам физический процесс образования тепловой энергии и способ ее передачи между газообразными горючими веществами в нейтрально-негорючей среде.

Согласно классической теории взрыва Н.Н. Семенова, угольная пыль горит и взрывается в газовой фазе, а именно, при нагревании частиц угольной пыли выделяются летучие вещества с последующим их взрывом, а твердая фаза, следовательно, не принимает участие во взрыве, при достижении концентрации газов взрывоопасных пределов происходит их воспламенение [7].

Известны определения процесса горения. Горение - это быстрая химическая реакция соединения горючих компонентов с кислородом, сопровождающаяся интенсивным выделением тепла и резким повышением температуры. Это сложный физико-химический процесс взаимодействия горючего вещества и окислителя, характеризующийся самоускоряющимися превращениями и сопровождающийся выделением большого количества теплоты, света и дыма. О температуре известно, что как молекулярно-кинетическая величина она характеризует интенсивность хаотического движения молекул и измеряется их средней кинетической энергией. Также считается, что горючая смесь перед воспламенением нагревается до температуры воспламенения за счет теплопроводности и диффузии раскаленных продуктов сгорания и активных частиц (атомов и радикалов) в холодную смесь. Нельзя судить о скорости протекания реакции и механизме химических превращений.

Авторами $[13,14]$ на основе молекулярно-кинетических законов был разработан механизм горения и взрыва метана и угольной пыли.

\section{УСЛОВИЯ РАСПРЕДЕЛЕНИЯ МОЛЕКУЛ МЕТАНА И АЭРОЗОЛЬНЫХ ЧАСТИЦ ПЫЛИ В ГОРНОЙ ВЫРАБОТКЕ}

От этих условий зависят способ и механизм распространения в горючей среде процессов, известных как горение и взрыв горючих веществ. Горная выработка имеет ограниченное пространство, границами которого являются неподвижные и непроницаемые поверхности. Метан - это газ, молекулы которого находятся в таком агрегатном состоянии, в котором его частицы не связаны молекулярными силами. Угольная пыль имеет твердое состояние, но по своим тонкодисперсным размерам и свойствам находится в воздухе продолжительное время, и ее можно условно отнести к газообразным веществам. Общим у них является то, что отдельные молекулы и частицы не находятся в контакте друг с другом, а условно равномерно распределены в объеме выработки в окружении негорючих молекул воздуха (азота и кислорода). Из-за неравномерной скорости воздуха молярная концентрация метана может быть больше там, где скорость воздуха меньше, например на периферии потока и у аэродинамических сопротивлений.

Среднее расстояние между молекулами метана зависит от объемной концентрации. Это расстояние значительно превышает размеры самих молекул (табл. 1).

Размер любых атомов равен 0,1 нм, молекул $\mathrm{CH}_{4}-0,45$ нм; $\mathrm{O}_{2}-0,3$ нм; $\mathrm{H}_{2}-0,25$ нм; $\mathrm{N}_{2}-0,32$ нм. При объемной в воздухе концентрации 1\% молекула метана находится в окружении 100 молекул кислорода и азота, а при концентрации 5\% - в окружении 20 молекул. Аэрозольные фракции угольной пыли могут перемещаться по выработке в виде облака, но также находятся в окружении большого количества негорючих элементов.

\section{МОЛЕКУЛЯРНАЯ СТРУКТУРА МЕТАНА и угольной пыли}

В настоящее время доказано, что все вещества в любом агрегатном состоянии состоят из молекул и макромолекул. С метаном все ясно. С угольными частицами необходимо разобраться. В горной литературе продолжают рассматривать угольный пласт как материал однородный, изотропный с распределенным равномерно метаном и одинаковыми другими свойствами. Это объясняется тем, что авторы незнакомы с закономерностями образования угольных пластов. Учитывают только его горючие свойства.

Месторождения угля в форме пластов имеют слоистую структуру и состоят из пачек, в состав горной массы пласта входят влага, органическая и неорганическая масса. Основным полезным компонентом является органическая часть угольного пласта. В угольном пласте горючими веществами являются метан и органическая часть, которая имеет растительную основу и состоит из углерода, водорода и кислорода. 
Характеристика метановоздушной смеси в зависимости от концентрации метана при барометрическом давлении 104 даПа и температуре 293 K

\begin{tabular}{|c|c|c|c|c|c|c|}
\hline \multicolumn{2}{|c|}{$\begin{array}{c}\text { Объемная } \\
\text { концентрация, С в } 1 \text { м³ \% }\end{array}$} & \multicolumn{2}{|c|}{$\begin{array}{c}\text { Количество молей в } 1 \text { м³, } \\
\text { n, моль }\end{array}$} & \multirow{2}{*}{$\begin{array}{c}\text { Отношение } \\
\text { молей в } 1 \text { м }^{3} \\
\mathrm{O}_{2} / \mathrm{CH}_{4}\end{array}$} & \multicolumn{2}{|c|}{$\begin{array}{c}\text { Расстояние } \\
\text { между молекулами, l, нм }\end{array}$} \\
\hline $\mathrm{CH}_{4}$ & $\mathrm{O}_{2}^{*}$ & $\mathrm{CH}_{4}$ & $\mathrm{O}_{2}$ & & $\mathrm{CH}_{4}$ & $\mathrm{O}_{2}$ \\
\hline 0 & 20 & 0 & 8,810 & - & - & 20,25 \\
\hline 1 & 19,8 & 0,441 & 8,722 & 19,80 & 54,97 & 20,32 \\
\hline 2 & 19,6 & 0,881 & 8,634 & 9,80 & 43,63 & 20,39 \\
\hline 3 & 19,4 & 1,332 & 8,546 & 6,416 & 38,11 & 20,46 \\
\hline 4 & 19,2 & 1,762 & 8,458 & 4,800 & 34,63 & 20,53 \\
\hline 5 & 19,0 & 2,203 & 8,370 & 3,799 & 32,15 & 20,60 \\
\hline 15 & 17,0 & 6,608 & 7,489 & 1,133 & 22,29 & 21,38 \\
\hline
\end{tabular}

Из-за отсутствия исследований петрогафической и химической структуры угольного вещества распространенные теории горения и взрыва основывались на общих законах термодинамики. Без анализа генетических основ составляли вероятные структурные схемы макромолекул [15] с химической формулой $\mathrm{C}_{28} \mathrm{H}_{18} \mathrm{O}_{2}$ (puc. $1, a$ ).

Авторами теоретически исследована генетика торфоотложения [16]. Органическая масса угля состоит из разложившихся макромолекул целлюлозы (50-70\%), лигнина (30\%), жиров, воска. Химическая формула молекулыцеллюлозы $\left[\mathrm{C}_{6} \mathrm{H}_{10} \mathrm{O}_{5}\right]_{n}$ смолекулярноймассой80000150000 г/моль, а лигнина - $\mathrm{C}_{50} \mathrm{H}_{49} \mathrm{O}_{11}$. Авторы определили среднестатистическую формулу макромолекулы торфа $\mathrm{C}_{1403} \mathrm{H}_{1362} \mathrm{O}_{278} \mathrm{~N}_{10} \mathrm{Si}_{10} \mathrm{Al}_{10}$. Масса атомов в молекуле $3,88 \times 10^{-20}$ г. В угольных пластах в результате различия фациальных условий отложения торфа и последующих процессов метаморфизма количество химических элементов может незначительно отличаться.

Аэрозольные фракции угля имеют молекулярную структуру, так как являются частицей основной органической массы угольного пласта. В настоящее время технический анализ угля в пласте подтверждает содержание горючих химических элементов углерода и водорода в горючей масce (пабл. 2).

Расчеты показали, что в макромолекуле масса углерода составляет 74,4\%, водорода - 6\%, а кислорода 19,6\% [16].

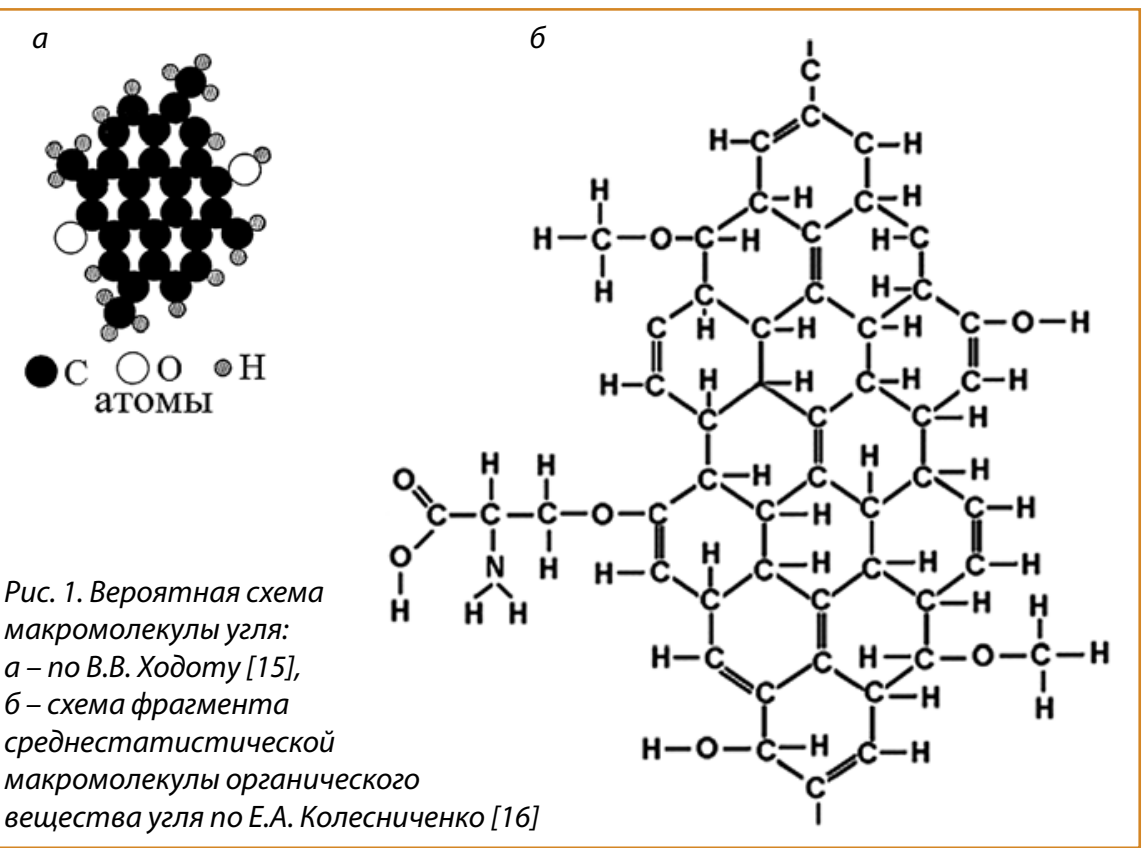

На шахте «Котинская» по замерам (см. табл. 2) элементного состава в 1 г угля содержится углерода 81,6\%, водорода $5,9 \%$, а кислорода $12,5 \%$.

Основным результатом установления такой молекулярной структуры является возможность оценки химической связи между атомами и расчета эндотермических затрат на отделение всех химических элементов. Реальное количество этих химических элементов определяется в результате элементного анализа угля (см. табл. 2).

\section{ОБЩЕЕ ПРЕДСТАВЛЕНИЕ О ГОРЕНИИ И ВЗРЫВЕ}

Аварийный внешний источник тепловой энергии нагревает небольшой объем горючей среды в выработке. В среднем этот объем не превышает 0,2 м³. В этом объеме начинаются процессы разрушения молекул и объединение атомов в молекулы. Так, тепловой энергии должно быть достаточно, чтобы в молекуле метана разорвать электромагнитные связи углерода с четырьмя атомами водорода. На отрыв одного атома необходимо затратить 3,46 эВ или 339 кДж/ моль. В угольной фракции происходит последовательнопараллельное разрушение макромолекул (см. рис. 1, б). После прекращения действия внешнего источника этот объем сам становится инициатором реакций в горючей среде горной выработки. Тепловая энергия от возникшего источника тепловой энергии передается молекулам горючих веществ, которые воспроизводят новую тепловую энергию, и в зависимости от скорости передачи тепловой энергии между молекулами в горючей среде процесс принято называть горением или взрывом.

\section{ЭЛЕКТРОМАГНИТНЫЙ \\ ПРИНЦИП ПЕРЕНОСА \\ ТЕПЛОВОЙ ЭНЕРГИИ}

Представления о том, что такое молекула в химии и физике, несколько различаются. В химии под молекулами понимают наименьшие одинаковые структурные элементы вещества, из которых оно может быть построено. В физике под молекулами понимают наименьшие одинаковые структурные образования, сохраняющие свою индивидуальность при разделении вещества на такие мельчайшие частицы. При таких превращениях, как раство- 
Результаты определения элементного содержания горючих химических элементов С и Н в угольных пластах на шахтах АО «СУЭК»

\begin{tabular}{|c|c|c|c|c|c|}
\hline \multirow{2}{*}{ Шахта } & \multicolumn{2}{|c|}{ Выход летучих веществ } & \multicolumn{3}{|c|}{ Элементный состав угля в с.6.м., \% } \\
\hline & В горной массе, Vа, \% & B c.6.M., Vdaf, \% & Cdaf $^{\text {dat }}$ & $\mathbf{H}^{\text {daf }}$ & $\mathbf{O}^{\text {daf }}$ \\
\hline Котинская & $33,3-32,5$ & 42,3 & 79,2 & 5,7 & 12,1 \\
\hline Им. С.М. Кирова & $27-25,5$ & $42-43$ & 81,6 & 5,9 & $8,05-9,29$ \\
\hline Им. В.Д. Ялевского & $31,9-31,7$ & 43 & 82,5 & 5,9 & 9,9 \\
\hline Талдинская-Западная-1 & 28,4 & 37,4 & 80,79 & 5,45 & 10,74 \\
\hline Талдинская-Западная-2 & 27,5 & 37,6 & 81,5 & 5,2 & 10,4 \\
\hline Полысаевская & 33,7 & 55,2 & 82,04 & 5,75 & 8,54 \\
\hline Им. 7 Ноября & 31,6 & 44,8 & 81,3 & 5,5 & 9,9 \\
\hline Комсомолец & $30-27,9$ & 45,3 & 83,62 & 5,88 & 7,53 \\
\hline Им. А.Д. Рубана & 34,4 & 49,3 & 79,67 & 5,75 & 12,46 \\
\hline
\end{tabular}

рение, плавление, испарение, колодные превращения, метаморфизм, физические молекулы не разрушаются.

Объектом рассмотрения являются элементарные частицы как негорючего, так и горючего вещества - атомы и молекулы. В соответствии с принципом Паули (1925 г.) химические элементы имеют электронную структуру. Вокруг атома на орбитах обращаются электроны. Силы взаимодействия между атомами и молекулами имеют электромагнитную природу.

Первоначальными источниками тепловой энергии могут быть молекулы химических веществ, образующихся при возгорании спички, свечи, молекулы мельчайших частичек раскаленного светящегося вещества и молекулы газа между электродами при возникновении электрической искры. Эти молекулы испускают электромагнитные волны (фотоны), которые поглощаются молекулами воздуха, метана и угольной пыли. Испускаемое электромагнитное излучение с длиной световой волны от 400 до 700 нм регистрируется как свечение или возгорание.

\section{ОБРАЗОВАНИЕ И ПЕРЕНОС ФОТОНОВ}

Каждая молекула обладает внутренней потенциальной и кинетической энергией. Потенциальная энергия сосредоточена в протоне атома. Кинетическая энергия определяется подвижностью атомов. Атомы и молекулы обладают кинетической энергией и находятся постоянно в движении [17]. Этим и определяются их объемное расположение и расстояние между ними в пространстве. Атом состоит из атомной оболочки и электронов, расположенных на круговых орбитах (рис. 2).

Электроны на орбите 1s находятся на самом нижнем уровне, ближе к ядру. Орбиты 2s и 2p являются главными, а на диффузной линии расположены орбиты 3s, 3p, 3d. Электроны могут переходить с нижнего уровня на расположенный выше, а затем перескакивать снова на нижний. Между атомом и электронами существует химическая связь. Количество связей зависит от количества электронов. Например, два электрона - двойная связь двухвалентная. При нормальном состоянии атома электроны находятся на орбитах около ядра, в минимальном энергетическом состоянии. В молекулах атомы объединяются связующими орбителями, на которых электроны также находятся в нор- мальном состоянии на низком энергетическом уровне.

Фотон - это квант световой энергии, испускаемой электроном. При поглощении молекулой фотона, выпущенного источником, один из электронов переходит с 1-го на более высокий энергетический 2-й уровень (рис. 3, а).

Для перевода электрона на более высокий уровень фотон должен обладать определенным количеством энергии. Энергия фотона - это энергия перескока электрона с основного уровня 1 на возбужденный уровень 2, равная разности между энергиями (см. рис. 3):

$E_{2}-E_{1}=h \times v$, где: $h$ - постоянная Планка, $v$ - частота электромагнитного излучения.

Если отключить источник поступающих фотонов, то электрон вернется суровня 2 в исходное положения, высвобождая энергию в виде фотона (см. рис. 3, б). При увеличении действия источника фотоны прилетят к возбужденному атому, который был уже возбужден. Поэтому под воздействием фотона атом выбрасывает первый фотон. Затем выбрасывает свой и опускается в нормальное состояние (рис. 3, в). Дальше летят два фотона. Эти два выбивают четыре, а те - восемь, а восемь выбивают 16 и т.д.

\section{ПЕРВЫЙ ТИП ПЕРЕДАЧИ ФОТОНОМ ТЕПЛОВОЙ ЭНЕРГИИ}

При поглощении молекулой фотона увеличиваются ее кинетическая энергия и скорость вращения электрона. Переход электрона на внешнюю орбиту увеличивает рассто-

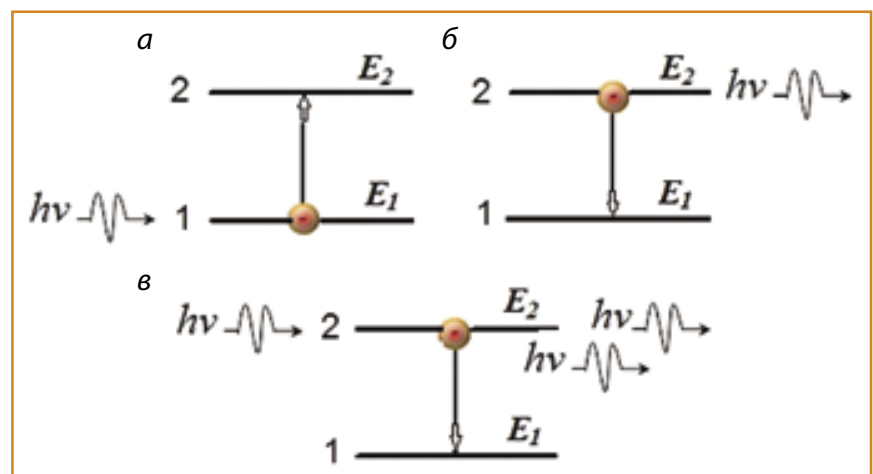

Рис. 3. Схема образования и переноса фотонов 
яние между атомами, что приводит к расширению вещества и ослаблению межатомного взаимодействия. Увеличиваются размеры молекулы и ее скорость. Излучение фотонов и изменение скорости внешних электронов и размеров молекул воспринимаются как изменение температуры. Это тепловая энергия.

\section{ВТОРОЙ ТИП ПЕРЕДАЧИ ЭНЕРГИИ}

Второй тип передачи энергии проявляется при соударении молекул с разными скоростями и их механическом сжатии. При соударении молекул в результате уменьшения скорости и сжатия электроны перескакивают на нижний уровень и излучают высвободившуюся энергию в виде фотона.

Можно сделать такой вывод. При механическом сжатии газа происходит излучение фотонов энергии атомами и в результате - его нагревание. На практике это применяют при сжатии углеводородного горючего $\mathrm{C}_{14} \mathrm{H}_{30}$ в дизельном двигателе и в обосновании механизма зажигания газа в ударной волне.

\section{ПЕРЕНОС ЭНЕРГИИ В ГОРЮЧЕЙ СРЕДЕ}

В область воздействия образовавшегося внешнего теплового источника попадают молекулы азота, кислорода, метана и угольной пыли. При отсутствии метана и угольной пыли молекулы воздуха, поглощая фотоны энергии, приобретают кинетическую энергию. При этом ощущается повышение температуры воздуха. Если под действием фотонов произойдет разрушение молекул азота или кислорода на атомы, то возбужденные электроны испускают ровно столько энергии, сколько получили, и молекулы снова восстанавливаются. Присутствие горючих метана и угольной пыли включает новые химические реакции.

\section{ЗАТРАТЫ ЭНЕРГИИ ФОТОНОВ НА РАЗРУШЕНИЕ МОЛЕКУЛ МЕТАНА И УГОЛЬНОЙ ПЫЛИ}

Электроны молекулы метана, получив тепловые фотоны от источника, возбуждаются, и четыре атома водорода отсоединяются от одного атома углерода, образуя свободные радикалы. На разрушение одной молекулы затрачивается энергия электромагнитного излучения 14,08 эВ, или 1356 кДж/моль. Молекула угольной пыли состоит в основном из атомов углерода, водорода, кислорода (см. рис. 1, б). Мольная концентрация этих атомов известна по техническому анализу (см. табл. 2). Молекулы начинают разрушаться в результате попадания фотонов с поверхностного слоя частицы пыли. Атомы водорода, углерода и кислорода будут отрываться при поглощении энергии соответственно 3,46; 3,61 и 3,64 эВ на один атом или 339; 339 и 351 кДж/моль.

Для участия в химических реакциях молекулы кислорода будут разделены фотонами с энергией 5,13 эВ на молекулу, или 494 кДж/моль.

\section{ВЫДЕЛЕНИЕ ТЕПЛОВОЙ ЭНЕРГИИ}

Энергия выделяется электронами при перестройке электронных орбителей в образующихся продуктах реакций. Атом углерода оставляет связанными со своим ядром два электрона на внутренней орбите, а четыре электрона, находящиеся на его внешней орбите, распределяются по два электрона на каждый атом кислорода, которые в свою очередь отдают каждый по два электрона для общей связи атома углерода. При образовании одной молекулы диоксида углерода $\mathrm{CO}_{2}$ в окружающую среду выделяется энер- гии 7,48 эВ или 720 кДж/моль. Образующиеся две молекулы воды $2 \mathrm{H}_{2} \mathrm{O}$ при объединении четырех атомов водорода выделяют 9,06 эВ и при присоединении двух атомов кислорода - 5,15 эВ. Всего выделяется 14,19 эВ, или 1367 кДж/ моль. Кроме этого, одновременное излучение фотонов при образовании двух молекул воды выделяет еще 5,98 эВ, или 576 кДж/моль и генерирует энергию взрыва 20,17 эВ, или 1943 кДж/моль.

\section{РАСПРОСТРАНЕНИЕ ВЗРЫВА В ГОРЮЧЕЙ СРЕДЕ}

На разрушение одной молекулы $\mathrm{CH}_{4}$ и одной молекулы О, источником энергии было затрачено 19,21 эВ. Образующиеся одна молекула $\mathrm{CO}_{2}$ и две $\mathrm{H}_{2} \mathrm{O}$ выделили 27,65 эВ, т.е. в 1,44 раза больше, чем затрачено. Эти молекулы инициировали дальнейший процесс в горючей среде. Перемещение фотонов показывает световые границы физических процессов. Распространение горения в пылевой среде не отличается от распространения в метановоздушной. Скорость распространения горения и взрыва зависит от концентрации метана и дисперсной пыли в шахтном воздухе.

\section{выводы}

Представленные результаты имеют научное значение, так как впервые процессы инициирования и распространения горения и взрыва метана и угольной пыли обоснованы распространением электромагнитного излучения на электронном уровне молекул. Практическое значение применяемого метода позволит разработать новые способы предотвращения взрыва. Описание реакции горения формулой $\mathrm{CH}_{4}+\mathrm{O}_{2}=\mathrm{CO}_{2}+2 \mathrm{H}_{2} \mathrm{O}$, как и математических интерпретаций виртуального горения и взрыва, недостаточно для решения проблем взрывоопасности в горных выработках.

\section{Список литературы}

1. Предупреждение и локализация взрывов в подземных условиях / А.Е. Умнов, А.С. Голик, Д.Ю. Палеев, Н.Р. Шевцов. М.: Недра, 1990. 286 с.

2. Laboratory and large-scale dust explosion research / K.L. Cashdollar, E.S. Weiss, N.B. Greninger, K. Chatrathi // Plant / Oper. Progr. 1992. Vol. 11. N 4. Pp. 247-255.

3. Laboratory and mine dust explosion research at the bureau of mines / Kenneth L. Cashdollar, Michael J. Sapko, Eric S. Weiss, Martin Hertzberg. Ind. Dust Explos.: Symp. Pittsburgh, Pa, 10-13 June, 1986. Philadelphia (Pa). 1987. Pp. 107-123.

4. Ishihama Wataru, Enomoto Heiji, Sekimoto Yoshinori. Pt. I. Experimental study on the explosion characteristics of coal dust-methane-air mixtures (Ist Report) // Journal Mining and Met. Inst. Jap. 1982. Vol. 98. N 1135. Pp. 933-937.

5. Петрухин П.М., Киреев А.М., Сергеев В.П. Исследование нижних пределов взрывчатости угольной пыли. В кн.: Борьба с газом и пылью в угольных шахтах. Киев: Техника, 1967. вып. 4. С. 48-59.

6. Цибульский В. Исследование предельных взрывоопасных концентраций угольной пыли / Труды Главного института горного дела GYH / Серия Л, 1954. 31 с.

7. Семенов Н.Н. Теория горения // Наука и жизнь. № 8-9. 1940. С. 3-12.

8. Зельдович Я.Б. Теория ударных волн и введение в газодинамику. М. - Л., Изд-во АН СССР, 1946. 187 с.

9. Льюис Б., Эльбе Г. Горение, пламя и взрывы в газах: пер. с англ. М.: Мир, 1968. 592 с. 
10. Mechanisms for the ignition of pulverized coal particles / V.S. Gururajan, T.F.Wall, R.P. Gupta, J.S. Truelove // Combust. and Flame. 1990. Vol. 81. N 2. Pp. 119-132.

11. Liu Yi, Sun Jinhua, Chen Dongliang. Flame propagation in hybrid mixture of coal dust and methane // J. Loss Prev. Process Ind. 2007. Vol. 20. N 4-6. Pp. 691-697.

12. Sigmar W. Mathematische Modellierung der Rohlenstaubverbrennug: Diss. Dokt.-Ing. Fak. Maschinenbau Ruhr-Univ. Bochum, 1989. Pp. 111-210.

13. Теория горения и взрыва метана и угольной пыли / И.Е. Колесниченко, В.Б. Артемьев, Е.А. Колесниченко и др. // Уголь. 2016. № 6. С. 30-35. URL: http://www.ugolinfo.ru/ Free/062016.pdf (дата обращения: 15.09.2018).
14. Предотвращение взрывов угольной пыли и метана в горных выработках: теория и практика / И.Е. Колесниченко, В.Б. Артемьев, Е.А. Колесниченко // Горная промышленность. 2017. № 4. С. 26-29.

15. Ходот В.В. Внезапные выбросы угля и газа. М.: ГНТИ, 1961. $363 \mathrm{c}$

16. Внезапные выбросы метана: теоретические основы / Е.А. Колесниченко, В.Б. Артемьев, И.Е. Колесниченко. М.:Горное дело ООО «Киммерийский центр», 2013. 232 с. (библиотека горного инженера. Т.9. «Рудничная аэрология». Кн. 6).

17. Матвеев А.Н. Молекулярная физика:Учебное пособие. 4-е изд. СПб.: Издательство «Лань», 2010. 368 с.

UDC 622.411.332:661.92:622.812.001.1 @ I.E. Kolesnichenko, V.B. Artemiev, E.A. Kolesnichenko, 2018

ISSN 0041-5790 (Print) • ISSN 2412-8333 (Online) • Ugol' - Russian Coal Journal, 2018, № 10, Pp. 36-41

SAFETY

\section{Title \\ SUBSTANTIATION OF ELECTROMAGNETIC RADIATION PRINCIPLE DURING INITIATION AND PROPAGATION OF METHANE OR COAL DUST EXPLOSION IN THE MINE ATMOSPHERE}

DOI: http://dx.doi.org/10.18796/0041-5790-2018-10-36-41

\section{Authors}

Kolesnichenko I.E. ${ }^{,}$Artemiev V.B. ${ }^{2,3}$, Kolesnichenko E.A. ${ }^{1}$

${ }^{1}$ Federal State-Funded Educational Institution of Higher Professional Education "Platov South Russia State Technical University (NPI)",

Shakhty, 346527, Russian Federation

2 "SUEK" JSC, Moscow, 115054, Russian Federation

${ }^{3}$ National University of Science and Technology "MISIS" (NUST "MISIS"), Moscow, 119049, Russian Federation

\section{Authors' Information}

Kolesnichenko I.E., Doctor of Engineering Sciences, Professor, Head of "Construction and technosphere safety" Department of Shahty Institute, e-mail: kolesnichenko-igor@rambler.ru Artemiev V.B., Doctor of Engineering Sciences, Deputy General Director Production Operations Director, Professor Safety and Ecology of Mining Department of Mining Institute, e-mail: pr_artem@suek.ru

Kolesnichenko E.A., Doctor of Engineering Sciences, Professor of "Construction and technosphere safety" Department of Shahty Institute, e-mail: kolesnichenko-2718@rambler.ru

\begin{abstract}
The paper discusses the problems of preventing methane and coal dust explosions. It provides the analysis of thermal energy physical nature concepts and ways of its propagation in a combustible medium. It shows the volumetric principle of methane and coal dust molecules distribution in the mine atmosphere. Mass content of carbon and hydrogen chemical elements in coal seams at the SUEK, OJSC mines is reported here. Possible patterns of coal macromolecules are given. The article rationalizes electromagnetic principle of thermal energy transfer between molecules of combustible substances. It is shown that, when ignited, the molecules of all external energy sources start emitting electromagnetic waves (photons) into the combustible medium. Physical mechanism of the energy photons formation and transfer is described. Two types of thermal energy transmission by photons are explained. The paper describes the process of energy transfer in a combustible medium and sets the physical rationale of thermal energy regeneration during formation of a carbon dioxide molecule and two water molecules. The process of the light front (flame) propagation, combustion and explosion of methane and coal dust is described.
\end{abstract}

\section{Keywords}

Molecules, Electromagnetic waves, Photon, Methane, Coal dust, Mine working, Kinetic energy, Electrons, Energy levels, Energy transfer, Electron orbitals, Propagation velocity, Combustion, Explosion.

\section{References}

1. Umnov A.E., Golik A.S., Paleev D.Yu., Shevcov N.R. Preduprezhdenie i lokalizatsiya vzryvov $v$ podzemnykh usloviyakh [Prevention and containment of explosions in underground conditions]. Moscow, Nedra Publ., 1990, 286 p.

2. Cashdollar K.L., Weiss E.S., Greninger N.B. \& Chatrathi K. Laboratory and largescale dust explosion research. Plant. Oper. Progr., 1992, Vol. 11, No. 4, Pp. 247-255. 3. Cashdollar Kenneth L., Sapko Michael J., Weiss Eric S. \& Hertzberg Martin Laboratory and mine dust explosion research at the bureau of mines. Ind. Dust Explos. Symp., Pittsburgh, Pa, 10-13 June, 1986, Philadelphia (Pa), 1987, Pp. 107-123.
4. Ishihama Wataru, Enomoto Heiji \& Sekimoto Yoshinori. Pt. I. Experimental study on the explosion characteristics of coal dust-methane-air mixtures (Ist Report). Journal Mining and Met., Inst. Jap., 1982, Vol. 98, No. 1135, Pp. 933-937. 5. Petruhin P.M., Kireev A.M. \& Sergeev V.P. Issledovanie nizhnikh predelov vzryvchatosti ugolnoy pyli. [Investigation of the lower limits of the coal dust explosibility] In the book: Borba s gazom ipylyu vugolnykh shakhtakh [Combating gas and dust in coal mines]. Kiev, Tekhnika Publ., 1967, issue 4, Pp. 48-59. 6. Cibulskij V. Issledovanie predelnykh vzryvoopasnykh kontsentratsiy ugolnoy pyli [Investigation of the maximum explosive concentrations of coal dust]. Trudy Glavnogo instituta gornogo dela [Proceedings of the Main Institute of Mining GYH], Series L, 1954, 31 p.

7. Semenov N.N. Teoriya goreniya [Combustion theory]. Nauka iZhizn-Science and Life, 1940, No. 8-9, Pp. 3-12.

8. Zeldovich Ya.B. Teoriya udarnykh voln ivvedenie v gazodinamiku [The theory of shock waves and introduction to gas dynamics]. Moscow - Leningrad, Publishing House Academy of Sciences of the USSR, 1946. $187 \mathrm{p}$.

9. Lewis B., Elbe G. Gorenie plamya i vzryvy v gazakh [Combustion, flames and explosions of gases]. Translated from English. Moscow, Mir Publ., 1968, 592 p. 10. Gururajan V.S., Wall T.F., Gupta R.P. \&Truelove J.S. Mechanisms for the ignition of pulverized coal particles. Combust. and Flame, 1990, Vol. 81, No. 2, Pp. 119-132. 11. Liu Yi, Sun Jinhua \& Chen Dongliang. Flame propagation in hybrid mixture of coal dust and methane. J. Loss Prev. Process Ind., 2007, Vol. 20, No. 4-6, Pp. 691-697.

12. Sigmar W. Mathematische Modellierung der Rohlenstaubverbrennug: Dr. eng. sci. diss., Fak. Maschinenbau Ruhr-Univ. Bochum, 1989, Pp. 111-210.

13. Kolesnichenko I.E., Artemiev V.B., Kolesnichenko E.A., Cherechukin V.G. \& Lubomischenko E.I. Teoriya goreniya i vzryva metana i ugolnoi pyli [The theory of combustion and explosion of methane and coal dust]. Ugol' - Russian Coal Journal, 2016, No. 6, Pp. 30-35. Available at: http://www.ugolinfo.ru/ Free/062016.pdf (accessed 15.09.2018).

14. Kolesnichenko I.E., Artemiev V.B. \& Kolesnichenko E.A. Predotvrashchenie vzryvov ugolnoy pyli i metana v gornykh vyrabotkakh: teoriya i praktika [Prevention of coal dust and methane explosions in mine workings: theory and practice]. Gornaya Promyshlennost - Mining Industry, 2017, No. 4, Pp. 26-29. 15. Hodot V.V. Vnezapnye vybrosy uglya i gaza [Sudden outbursts of coal and gas]. Moscow, State Scientific and Technical Publ., 1961, 363 p.

16. Kolesnichenko E.A., Artemiev V.B. \& Kolesnichenko I.E. Vnezapnye vybrosy metana: teoreticheskie osnovy [Sudden methane outbursts: theoretical basis]. Moscow, Gornoe delo Kimmeriyskiy tsentr LLC, 2013, 232 p. (Mining Engineer's Library, Vol. 9. "Rudnichnaya aehrologiya” [Mine aerology], Book 6).

17. Matveev A.N. Molekulyarnaya fizika: Uchebnoe-posobie-4-e-izd [Molecular physics: Tutorial. $4^{\text {th }}$ edition]. St. Petersburg, Lan Publ., 2010, 368 p. 


\section{Развитие процесса самонагревания}

\section{в скоплениях угля под действием молекулярной диффузии кислорода}

DOI: http://dx.doi.org/10.18796/0041-5790-2018-10-42-46

\author{
ЮТЯЕВ Евгений Петрович \\ Канд. техн. наук, \\ генеральный директор \\ АО «СУЭК-КузбасС», \\ 652507 , г. Ленинск-Кузнецкий, Россия, \\ тел.: +7 (38456) 9-33-11, \\ e-mail:suek-kuzbass@suek.ru
}

\section{ПОРТОЛА Вячеслав Алексеевич}

Доктор техн. наук, профессор,

профессор кафедры аэрологии,

охраны труда и природы

КузГТУ им. Т.Ф. Горбачева,

650000 , г. Кемерово, Россия,

тел.: +7 (905) 913-74-29,

e-mail:portola2@yandex.ru

\section{МЕШКОВ Анатолий Алексеевич \\ Канд. техн. наук, \\ первый заместитель генерального директора - \\ технический директор $А О$ «СУЭК-Кузбасс», \\ 652507 , г. Ленинск-Кузнецкий, Россия, \\ тел.: +7 (38456) 9-33-11, \\ e-mail: suek-kuzbass@suek.ru}

\section{ХАРИТОНОВ Игорь Леонидович}

Заместитель технического директора -

начальник технического управления

АО «СУЭК-Кузбасс»,

652507 , г. Ленинск-Кузнецкий, Россия,

тел.: +7 (38456)9-33-11,

e-mail:suek-kuzbass@suek.ru

\section{ЖДАНОВ Александр Николаевич}

Начальник технического отдела

АО «СУЭК-Кузбасс»,

652507, г. Ленинск-Кузнецкий, Россия,

тел.: +7 (38456) 9-33-11,

e-mail:suek-kuzbass@suek.ru

Неравномерность потребления угля, вызванная климатическими особенностями, приводит к формированию угольных складов, в которых длительное время может храниться уголь. Негативным последствием взаимодействия скоплений угля с окружающим воздухом является возникновение в штабелях очагов эндогенных пожаров, наносящих ущерб окружа- ющей среде и угрожающих здоровью людей, а также материальный ущербугольному предприятию ввидупотери качества товарной продукции. Проведенные расчеты показали, что за счет окисления содержащимся в пустотах скопления кислородом уголь может нагреться на 0,3-1,3 градуса. Поступление кислорода только за счет молекулярной диффузии может вызвать процесс самонагревания угля. Длительность нагрева до 70-140 C составляет 200-300 сут. Существенное замедление процесса самонагревания происходит при уплотнении угольных штабелей, что приводит к снижению пустотности скопления. Приведены результаты расчета тепловой депрессии, развиваемой прогретым углем. Установлено, что скорости фильтрации воздуха через скопление угля, возникающие от тепловой депрессии, способны вызвать образование очагов самовозгорания. Для предотвращения эндогенныхпожаров необходимо снижать проницаемость угольных скоплений и уменьшать химическую активность угля по отношению к кислороду. Ключевые слова: угольные склады, самовозгорание угля, молекулярная диффузия кислорода, очаги самонагревания, тепловая депрессия, скопления угля.

\section{ВВЕДЕНИЕ}

Климатические особенности регионов России и территорий стран экспортеров приводят к неравномерности использования угля в течение года. Основное потребление энергетического угля приходится на зимние месяцы, а в летний период существенно снижается применение угля для отопления жилых и производственных помещений. В результате такого колебания спроса за летние месяцы образуются запасы энергетического угля на складах, что негативно сказывается на состоянии окружающей природы и качестве хранимого угля. Так, ветер и атмосферные осадки выносят мелкую фракцию угля в атмосферу, водоемы и на земную поверхность. В процессе разложения и окисления угля кислородом воздуха образуются углекислый газ, оксид углерода, метан, предельные и непредельные углеводороды, также выносимые в атмосферу. Некоторые из этих газов являются токсичными, другие вызывают парниковый эффект, способствуя повышению температуры на планете.

Наиболее опасные последствия длительного хранения угля возникают при развитии очагов самовозгорания в штабеляхполезного ископаемого. Эндогенные пожары приводят кпотере добытого угля, выделению в окружающий воздух токсичных газов. Возникающие конвективные потоки воздуха усиливают вынос пыли из скопления высушенного угля и образование опасных газов. В районе очагов самовозгорания увеличивается вероятность отравления и полу- 
чения травм людьми. Учитывая опасность эндогенных пожаров для угледобывающих предприятий, проводятся широкие исследования процесса самовозгорания угля [1, 2, 3 , $4,5,6,7]$, воздействия различных составов на химическую активность угля по отношению к кислороду [8, 9].

Одним из условий развития очага самовозгорания является постоянный приток кислорода к активным центрам угля. Однако проходящий через уголь воздух неоднозначно воздействует на процесс самовозгорания. С повышением скорости его фильтрации увеличивается выделение тепла за счет окисления, но одновременно возрастает и вынос тепла потоком воздуха. Существенно сказывается на процессе самовозгорания и разброс физико-химических свойств угля. Поэтому имеются различные мнения о скоростях фильтрации воздуха через скопление угля, способствующих повышению температуры угля за счет его окисления кислородом. Так, из проведенных исследований $[10,11,12]$ следует, что возникновение очагов самовозгорания угля происходит при скорости фильтрации воздуха через разрыхленное скопление от $1,6 \cdot 10^{-3}$ до $1,5 \cdot 10^{-2} \mathrm{M} / \mathrm{c}$. По результатам моделирования [13] сделан вывод, что пожароопасная скорость воздуха находится в пределах $1,6 \cdot 10^{-4}-1,6 \cdot 10^{-5}$ м/с. В работе [14] утверждается, что для развития самовозгорания необходимо подавать воздух через уголь со скоростью 5·10-5 - $10^{-4} \mathrm{M} / \mathrm{c}$. В статье [4] показано, что оптимальная скорость воздуха, требуемая для возникновения очага самовозгорания угля, зависит от химической активности угля и увеличивается при повышении температуры скопления. Исследования проводились для шахт, где в результате работы вентиляторов проветривания создаются условия для фильтрации воздуха через теряемые скопления угля.

Между тем известны многочисленные случаи развития очагов самовозгорания в скоплениях угля, где нет принудительной фильтрации воздуха. Например, очаги самовозгорания возникают в трюмах кораблей, перевозящих уголь. Самовозгораются угольные склады, породные отвалы. В таких случаях повышение температуры может происходить за счет поглощения углем кислорода, содержащегося в пустотах скопления. Существенное значение может оказывать проникновение кислорода в скопление угля за счет молекулярной диффузии. Согласно закону Фика плотность потока молекул кислорода пропорциональна градиенту концентраций вещества, коэффициенту молекулярной диффузии и направлена из области с большей концентрацией в область с меньшей концентрацией этого вещества. Учитывая непрерывное поглощение кислорода активными центрами угля, будет существовать градиент его концентраций и создаются условия для движения молекул кислорода из атмосферного воздуха вглубь скопления угля. Поэтому необходимо оценить возможность развития очагов самовозгорания под действием кислорода, изначально имеющегося в пустотах скопления, а также поступающего из окружающей атмосферы благодаря молекулярной диффузии кислорода. Результаты исследований позволят предложить пути воздействия на этот процесс с целью предотвращения возникновения эндогенных пожаров в складах хранимого угля.

\section{ИССЛЕДОВАНИЕ ПРОЦЕССА САМОВОЗГОРАНИЯ УГОЛЬНОГО СКОПЛЕНИЯ}

Источником тепла процесса самовозгорания является реакция окисления горючих компонентов угля кислоро- дом воздуха. Некоторое количество кислорода находится в порах и пустотах угольного скопления с момента формирования угольного склада. Для оценки влияния изначально содержащегося в скоплении угля кислорода на процесс самовозгорания необходимо учесть, что количество тепла, выделившегося при поглощении содержащегося в пустотах скопления кислорода, описывается уравнением:

$$
M=Q C m V_{1}
$$

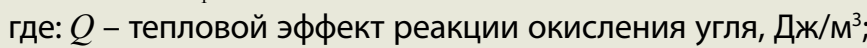
$C$ - концентрация кислорода, объемная доля; $m$ - пустотность скопления угля, доли единицы; $V_{1}$ - объем скопления угля, $\mathrm{M}^{3}$.

Изменение температуры скопления в зависимости от количества выделившегося тепла можно определить по формуле:

$$
M=\Delta T \rho_{1} c_{1}(1-m) V_{1^{\prime}}
$$

где: $\Delta T$ - изменение температуры скопления угля, $K$; - плотность угля, кг/м³ $c_{1}$ - удельная теплоемкость угля, Дж/(кг·К).

Приравнивая уравнения (1) и (2), получаем следующее выражение для расчета изменения температуры скопления угля, происходящего при поглощении имеющегося в пустотах кислорода:

$$
\Delta T=\frac{Q C m}{\rho_{1} c_{1}(1-m)} .
$$

Проведенный расчет показал, что при полном поглощении содержащегося в пустотах и порах скопления угля кислорода возможно незначительное повышение температуры. Уменьшение пустотности снижает количество выделившегося тепла. Так, при пустотности $m=0,4$ температура угля может повыситься на 1,3 градуса, при $m=0,25$ на 0,6 градуса, а при $m=0,15$ только на 0,3 градуса.

Исследование развития процесса самовозгорания угля под действием молекулярной диффузии кислорода проводилось методом математического моделирования. В математической модели использовались уравнения, описывающие нестационарный тепло- и массоперенос в одномерном скоплении угля. Перенос тепла, выделяемого при окислении угля кислородом, осуществлялся за счет теплопроводности. На границах скопления происходит теплообмен с окружающим воздухом. Концентрация кислорода в воздухе на границах скопления угля не меняется во времени. С учетом переноса кислорода за счет молекулярной диффузии и экспоненциальной зависимости скорости сорбции кислорода углем от температуры использовались следующие уравнения:

$$
\begin{aligned}
& (1-m) \rho_{1} c_{1} \frac{\partial T}{\partial \tau}= \\
& =\lambda \frac{\partial^{2} T}{\partial x^{2}}(1-m)+(1-m) \rho_{1} C Q K \exp (-E / R T) ; \\
& m \frac{\partial C}{\partial \tau}=m D \frac{\partial^{2} C}{\partial x^{2}}-(1-m) \rho_{1} C K \exp (-E / R T) ; \\
& \left.\lambda \frac{\partial T}{\partial x}\right|_{x=0}=\alpha_{1}\left(T-T_{0}\right) ;\left.\lambda \frac{\partial T}{\partial x}\right|_{x=L}=\alpha_{2}\left(T-T_{0}\right) ; \\
& T(x, 0)=T_{0} ; C(0, \tau)=C(L, \tau)=C(x, 0)=C_{0},
\end{aligned}
$$

где: $T$ - температура, К; $\tau$ - время, с; $\lambda$ - коэффициент теплопроводности угля, Вт/(м·К); $K$ - константа скорости окисления, $\mathrm{M}^{3} /(\mathrm{\kappa г} \cdot \mathrm{c}) ; E$ - энергия активации, Дж/моль; $R$ - газовая постоянная, Дж/(моль·К); $D$ - коэффициент молекулярной 
Распределение температуры и концентрации кислорода в скоплении угля пустотностью 0,4

\begin{tabular}{|c|c|c|c|c|c|}
\hline \multirow{2}{*}{$\begin{array}{l}\text { Расстояние от границы } \\
\text { скопления, м }\end{array}$} & \multirow{2}{*}{$\begin{array}{c}\text { Температура и концентрация } \\
\text { кислорода }\end{array}$} & \multicolumn{4}{|c|}{ Время самонагревания, сут. } \\
\hline & & 7 & 50 & 120 & 250 \\
\hline \multirow[t]{2}{*}{0,0} & $\mathrm{~T},{ }^{\circ} \mathrm{C}$ & 21,2 & 24,4 & 27,0 & 30,0 \\
\hline & C, \% & 20,0 & 20,0 & 20,0 & 20,0 \\
\hline \multirow[t]{2}{*}{0,3} & $\mathrm{~T},{ }^{\circ} \mathrm{C}$ & 27,1 & 57,7 & 94,5 & 121,0 \\
\hline & C, \% & 14,3 & 11,2 & 7,3 & 5,3 \\
\hline \multirow[t]{2}{*}{0,6} & $\mathrm{~T},{ }^{\circ} \mathrm{C}$ & 27,2 & 70,3 & 111,0 & 143,0 \\
\hline & $\mathrm{C}, \%$ & 10,5 & 6,0 & 2,3 & 1,1 \\
\hline \multirow[t]{2}{*}{0,9} & $\mathrm{~T},{ }^{\circ} \mathrm{C}$ & 25,6 & 69,5 & 113,0 & 143,0 \\
\hline & C, \% & 9,0 & 3,2 & 0,7 & 0,1 \\
\hline \multirow[t]{2}{*}{1,2} & $\mathrm{~T},{ }^{\circ} \mathrm{C}$ & 25,3 & 66,2 & 112,0 & 143,0 \\
\hline & C, \% & 6,4 & 1,9 & 0,2 & 0,0 \\
\hline \multirow[t]{2}{*}{1,5} & $\mathrm{~T},{ }^{\circ} \mathrm{C}$ & 25,2 & 63,7 & 108,0 & 143,0 \\
\hline & C, \% & 5,7 & 1,4 & 0,1 & 0,0 \\
\hline
\end{tabular}

диффузии кислорода, м²/с; - коэффициент теплоотдачи от угля, Вт/(м².K); $L$ - размер угольного скопления, м.

Решение системы уравнений (4) осуществлялось конечно-разностным методом с реализацией на ПЭВМ. В расчетах использовалось скопление угля со следующими базовыми параметрами: $L=3,0 \mathrm{M} ;=1200 \mathrm{kг} / \mathrm{m}^{3}$; $c_{1}=1,05 \mathrm{kДж/кг;}=0,116 \mathrm{Bт} /(\mathrm{\kappa} г \cdot \mathrm{K}) ; Q=12,5 \mathrm{MД} / \mathrm{m}^{3} ; E=20,89$ кДж/моль; $D=1,8 \cdot 10^{-5} \mathrm{M}^{2} / \mathrm{c} ; K=4 \cdot 10^{-5} \mathrm{M}^{3} /($ кг·c). Для упрощения решения на границах скопления использовались одинаковые коэффициенты теплоотдачи, что позволяло получить симметричные по отношению центра скопления результаты.

Полученное в результате моделирования распределение температуры и концентрации кислорода в скоплении угля пустотностью 0,4 в различные моменты времени приведено в табл. 1 .

Результаты исследования показывают, что при отсутствии конвективных потоков воздуха в угольном скоплении происходит процесс самонагревания только за счет молекулярной диффузии кислорода. Из-за быстрой убыли кислорода повышение температуры угля происходит медленно. Скорость увеличения температуры угля постепенно снижалась. Так, в течение первых 50 суток температура угля возрастала в среднем на 1 градус в сутки, через 120 суток темпы разогрева уменьшились до 0,58 градусов в сутки, а на 200 сутки упала до 0,24 градусов в сутки. Максимальная температура располагается на глубине около 0,6 м от поверхности скопления. Концентрация кислорода быстро падает с расстоянием от поверхности угольного скопления. По мере увеличения температуры градиент концентрации кислорода возрастает, что приводит к росту химической активности угля.

Для оценки влияния уплотнения угольного скопления на процесс самонагревания проводился расчет для скопления пустотностью 0,15. Результаты расчета приведены в табл. 2.

Сравнивая полученные результаты, можно сделать вывод, что уплотнение угольных скоплений существенно замедляет процесс самонагревания. Например, при пустотности 0,15 скопление угля достигло температуры $71^{\circ} \mathrm{C}$ только на 340 сутки. Причем скорость повышения температуры очень быстро снижалась по мере самонагревания угля. Так, в первые пять суток рост температуры составил 1 градус в сутки, на 30 сутки уменьшился до 0,47 градусов в сутки, а через 300 суток понизился до 0,05 градусов в сутки.

Проведенные расчеты показали, что молекулярной диффузии кислорода достаточно для развития процесса самонагревания в скоплении угля. Однако по мере увеличения температуры скорость повышения температуры снижается, и происходит стабилизация температуры. Величина достигаемой температуры зависит от пустотности скопления. По мере уплотнения скопления угля скорость самонагре-

Таблича 2

\section{Распределение температуры и концентрации кислорода} в скоплении угля пустотностью 0,15

\begin{tabular}{|c|c|c|c|c|c|}
\hline \multirow{2}{*}{$\begin{array}{c}\text { Расстояние от границы } \\
\text { скопления, м }\end{array}$} & \multirow{2}{*}{$\begin{array}{c}\text { Температура и концентрация } \\
\text { кислорода }\end{array}$} & \multicolumn{4}{|c|}{ Время самонагревания, сутки } \\
\hline & & 5 & 37 & 107 & 340 \\
\hline \multirow[t]{2}{*}{0,0} & $\mathrm{~T},{ }^{\circ} \mathrm{C}$ & 21,2 & 23,0 & 24,2 & 25,1 \\
\hline & C, \% & 20,0 & 20,0 & 20,0 & 20,0 \\
\hline \multirow[t]{2}{*}{0,3} & $\mathrm{~T},{ }^{\circ} \mathrm{C}$ & 25,3 & 38,5 & 50,8 & 61,0 \\
\hline & $C, \%$ & 10,3 & 9,0 & 7,6 & 6,4 \\
\hline \multirow[t]{2}{*}{0,6} & $\mathrm{~T},{ }^{\circ} \mathrm{C}$ & 24,4 & 40,0 & 56,7 & 71,0 \\
\hline & C, \% & 5,3 & 4,0 & 2,6 & 1,6 \\
\hline \multirow[t]{2}{*}{0,9} & $\mathrm{~T},{ }^{\circ} \mathrm{C}$ & 23,4 & 36,4 & 54,3 & 71,0 \\
\hline & C, \% & 2,8 & 2,0 & 1,0 & 0,4 \\
\hline \multirow[t]{2}{*}{1,2} & $\mathrm{~T},{ }^{\circ} \mathrm{C}$ & 23,0 & 32,6 & 50,7 & 71,0 \\
\hline & C, \% & 1,6 & 1,0 & 0,3 & 0,0 \\
\hline \multirow[t]{2}{*}{1,5} & $\mathrm{~T},{ }^{\circ} \mathrm{C}$ & 22,5 & 30,8 & 48,6 & 71,0 \\
\hline & C, \% & 1,1 & 0,6 & 0,1 & 0,0 \\
\hline
\end{tabular}


Величина тепловой депрессии и скорости конвективного потока воздуха в скоплении угля в процессе самонагревания

\begin{tabular}{|c|c|c|c|c|c|c|c|c|}
\hline \multirow{2}{*}{ Показатели } & \multicolumn{8}{|c|}{ Пустотность скопления } \\
\hline & \multicolumn{4}{|c|}{0,4} & \multicolumn{4}{|c|}{0,15} \\
\hline Длительность самонагревания, сут. & 7 & 50 & 120 & 250 & 5 & 37 & 107 & 340 \\
\hline Средняя температура прогретой зоны, ${ }^{\circ} \mathrm{C}$ & 25,26 & 58,60 & 94,25 & 120,5 & 23,30 & 33,55 & 47,55 & 61,68 \\
\hline$\Delta \rho, \mathrm{kr} / \mathrm{M}^{3}$ & 0,021 & 0,148 & 0,256 & 0,323 & 0,014 & 0,057 & 0,110 & 0,159 \\
\hline$H, \Pi а$ & 0,122 & 0,870 & 1,51 & 1,90 & 0,031 & 0,120 & 0,240 & 0,350 \\
\hline$V \cdot 10^{6}, \mathrm{M} / \mathrm{C}$ & 0,69 & 4,96 & 8,61 & 10,83 & 0,17 & 0,68 & 1,37 & 1,99 \\
\hline
\end{tabular}

вания замедляется. Снижается также и величина достигаемой температуры. За счет длительности процесса самонагревания (сотни суток) угольное скопление прогревается на несколько метров.

Возникающая в результате молекулярной диффузии кислорода температурная аномалия в скоплении угля может вызвать приток воздуха в скопление угля за счет образования конвективных потоков в результате действия тепловой депрессии. Перепаддавления воздуха в скоплении угля, вызванный тепловой аномалией, можно определить из уравнения:

$H=\Delta \rho q m L_{T^{\prime}}$

где: $\Delta \rho$ - разность плотностей воздуха между окружающей атмосферой и прогретой зоной в скоплении угля,

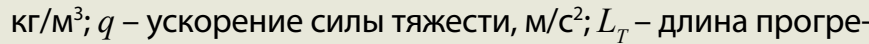
той зоны, м.

Учитывая уравнения состояния газа, изменение плотности воздуха в зависимости от температуры можно рассчитать по формуле:

$$
\Delta \rho=\rho_{0} T_{0} \frac{\left(T_{T}-T_{V}\right)}{T_{T} T_{V}},
$$

где: $\rho_{0}$ - плотность воздуха при нормальных условиях $\left(T_{0}=273 \mathrm{~K}\right), \mathrm{k} г \mathrm{M}^{3} ; T_{T}$-средняя температура нагретого в скоплении угля воздуха, К; $T_{V}$ - температура атмосферного воздуха, К.

Под действием перепада давления газа, вызванного тепловой депрессией, через скопление угля начнется фильтрация воздуха. При ламинарном режиме течения в скоплении угля скорость движения воздуха можно определить из уравнения:

$$
v=\frac{H K}{\mu L_{S}},
$$

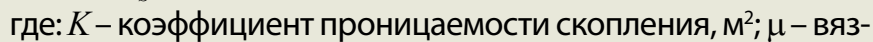
кость воздуха, (Н·c)/м²; $L_{S}$ - длина пути фильтрации воздуха, м.

Значения средней температуры угольного скопления в различные периоды времени, образующейся разности плотности воздуха, возникающего перепада давления газа за счет тепловой депрессии нагретого воздуха и скорости фильтрации воздуха через скопление угля приведены в табл. 3. Коэффициент проницаемости скопления угля в расчетах принят равным $10^{-9} \mathrm{M}^{2}$. Длина пути фильтрации воздуха равна 10 м, а длина прогретой зоны равна 1,5 м. Температура воздуха в окружающей атмосфере составляла $20^{\circ} \mathrm{C}$.

Анализируя полученные результаты можно сделать вывод, что температурные аномалии, формируемые при окислении угля кислородом, поступающим за счет молекулярной диффузии, достаточны для возникновения конвективных потоков воздуха в скоплении со скоростью $10^{-5}-10^{-6} \mathrm{M} / \mathrm{c}$. Для скоплений с большим коэффициентом проницаемости и меньшей длиной пути фильтрации ско- рость воздуха может возрасти до $10^{-4} \mathrm{M} / \mathrm{c}$. Согласно работам $[4,13,14]$ притока воздуха с такими скоростями достаточно для формирования очагов эндогенных пожаров в скоплениях угля.

\section{ЗАКЛЮЧЕНИЕ}

Проведенные исследования показали, что имеющееся в пустотах и порах угольного скопления количество кислорода может повысить температуру угля только на 0,3- 1,3 градуса. Поступление кислорода в скопление только за счет молекулярной диффузии кислорода способно сформировать очаги самонагревания с температурой до $70-140{ }^{\circ} \mathrm{C}$. Однако длительность такого процесса составляет 200-300 сут. Поэтому сформироваться очаги самонагревания могут только при длительном хранении угля или углесодержащих пород. Длительность процесса нагревания угля и достигаемая температура очага зависят от пустотности скопления. Уплотнение скоплений угля существенно замедляет процесс самонагревания и снижает температуру зоны прогрева.

Возникающие за счет молекулярной диффузии кислорода тепловые аномалии могут сформировать через угольные скопления конвективные потоки воздуха, интенсифицирующие приток кислорода и выделение тепла. Наибольший прирост температуры происходит в зонах с повышенным коэффициентом проницаемости скопления угля. Снизить опасность возникновения очагов эндогенных пожаров позволяют уменьшение проницаемости скопления за счет уплотнения и снижение химической активности угля, достигаемое обработкой антипирогенами.

\section{Список литературы}

1. Analytical prediction of coal spontaneous combustion tendency: velocity range with possibility of self-ignition / Q. Lin, S. Wang, S. Song, Y. Liang, T. Ren // Fuel Processing Technology. 2017. N 159. Pp. 38-47.

2. Thermal behavior and microcharacterization analysis of second-oxidized coal / J. Deng, J.Y. Zhao, Y.N. Zhang, C.P.Wang, A.C. Huang, C.M. Shu // Journal of Thermal Analysis \& amp. 2017. N 127(1). Pp. 439-448.

3.Zhang L., Qin B. Rheological characteristics of foamed gel for mine fire control // Fire and Materials. 2016. N 40(2). Pp. 246-260.

4. Portola V.A. Assessment of the effect of some factors on spontaneous coal combustion // Journal of Mining Science. 1996. N 32(6). Pp. 536-541.

5. Rosema A., Guan Y., Veld H. Simulation of spontaneous combustion, to study the causes of coal fires in the Rujigou Basin // Article in Fuel. 2001. N 80(1). Pp. 7-16.

6. Wang Q.S., Guo D., Sun J.H. Spontaneous Combustion Prediction of Coal by $\mathrm{C} 80$ and ARC Techniques // Energy and Fuels. 2009. N 23(10). Pp. 4871-4876. 
7. Скочинский А.А., Огиевский В.М. Рудничные пожары. М.: Издательство «Горное дело» ООО «Киммерийский центр», 2011. 375 с.

8. Портола В.А., Храмцов В.И. Влияние применяемых в шахтах составов на склонность угля к самовозгоранию // Безопасность труда в промышленности. 2017. № 2. С. 56-59.

9. Син С.А., Портола В.А., Игишев В.Г. Повышение эффективности применения азота для борьбы с самовозгоранием угля в шахтах //Уголь. 2018. № 5. C. 51-57. doi: 10.18796/00415790-2018-5-51-57.

10. Маевская В.М. Определение влияния оптимальных утечек воздуха на процесс самовозгорания угля при щитовой системе разработки // Научные сообщения ВостНИИ по безопасности работ в промышленности. Кемерово, 1961. № 2. C. 54-62.
11. Маевская В.М., Белавенцев Л.П., Рапоцевич А.П. О допустимой депрессии щитовых выемочных участков //Уголь. 1968. № 10. С. 57-59.

12. Влияние режима проветривания щитовых выемочных участков на их пожароопасность / В.М. Маевская, А.П. Рапоцевич, Л.П. Белавенцев, П.А. Парахин // Вопросы безопасности в угольных шахтах. М.: Недра, 1969. ТІІ. С. 147-162.

13. Баев Х.А. Определение пожароопасной скорости фильтрации воздуха через угольные скопления // Техника безопасности, охрана труда и горноспасательное дело. 1969. № 11-12. С. 44-45.

14. Глузберг Е.И. Тепло- и массообмен в процессе самонагревания угольного скопления // Всесоюзный межвузовский сборник Физические процессы горного производства. 1978. Вып. 5. С. 66-70.

UDC 622.822 ๑ E.P. Yutyaev, V.A. Portola, A.A. Meshkov, I.L. Kharitonov, A.N. Zhdanov, 2018

SAFETY

ISSN 0041-5790 (Print) • ISSN 2412-8333 (Online) • Ugol' - Russian Coal Journal, 2018, № 10, Pp. $42-46$

Title

DEVELOPMENT OF SELF-HEATING PROCESS IN COAL STOCKS UNDER MOLECULAR DIFFUSION OF OXYGEN

DOI: http://dx.doi.org/10.18796/0041-5790-2018-10-42-46

\section{Authors' Information}

Yutyaev E.P. ${ }^{1}$, Portola V.A. ${ }^{2}$, Meshkov A.A. ${ }^{1}$, Kharitonov I.L. ${ }^{1}$, Zhdanov A.N. ${ }^{1}$

1 "SUEK-Kuzbass" JSC, Leninsk-Kuznetskiy, 652507, Russian Federation

${ }^{2}$ T.F. Gorbachev Kuzbass State Technical University (KuzSTU), Kemerovo, 650000, Russian Federation

\section{Authors' Information}

Yutyaev E.P., PhD (Engineering), General Director, tel.: +7 (38456) 9-33-11, e-mail: suek-kuzbass@suek.ru

Portola V.A., Doctor of Engineering Sciences, Professor, Professor of Aerology, labor protection and nature Department, tel.: +7 (905) 913-74-29, e-mail: portola2@yandex.ru

Meshkov A.A., PhD (Engineering), First Deputy General Director - Technical Director, tel.: +7 (38456) 9-33-11, e-mail: suek-kuzbass@suek.ru

Kharitonov I.L., Deputy Technical Director - Chief Technical Management, tel.: +7 (38456)9-33-11, e-mail: suek-kuzbass@suek.ru

Zhdanov A.N., Head Technical Department, tel.: +7 (38456) 9-33-11,

e-mail: suek-kuzbass@suek.ru

\section{Abstract}

Uneven consumption of coal, caused by climatic conditions, leads to the formation of coal stocks where coal can be stored for a long time. Negative consequences of the stockpiled coal interaction with the ambient air include occurrence of endogenous fires in coal stacks, causing damage to the environment and threatening human health, as well as material damage to the coal business due to salable product quality loss. Calculations made have shown that, being oxidized by oxygen contained in the stockpile voids, the coal can warm up by $0.3-1.3$ degrees. Oxygen delivered just through molecular diffusion can cause the process of coal self-heating. Heating up to $70-140^{\circ} \mathrm{C}$ would take 200-300 days. The self-heating process slows down significantly if the coal stacks are compacted giving less voids in a coal accumulation. The results of calculating thermal drop of ventilation pressure developed by the heated coal are given. It is established that velocities of air filtration through coal stockpiles arising from thermal drop of ventilation pressure can lead to formation of hot spots. To prevent endogenous fires, it is necessary to lower the permeability of coal stockpiles and reduce chemical activity of coal with respect to oxygen.

\section{Keywords}

Coal stocks, Spontaneous combustion of coal, Molecular diffusion of oxygen, Hot spots, Thermal drop of ventilation pressure, Coal stockpiles.

\section{References}

1. Lin Q., Wang S., Song S., Liang Y. \& Ren T. Analytical prediction of coal spontaneous combustion tendency: velocity range with possibility of self-ignition. Fuel Processing Technology, 2017, No. 159, Pp. 38-47.

2. Deng J., Zhao J.Y., Zhang Y.N., Wang C.P., Huang A.C. \& Shu C.M. Thermal behavior and microcharacterization analysis of second-oxidized coal. Journal of Thermal Analysis \& amp., 2017, No. 127(1). Pp. 439-448.
3. Zhang L. \& Qin B. Rheological characteristics of foamed gel for mine fire control. Fire and Materials, 2016, No. 40(2). Pp. 246-260.

4. Portola V.A. Assessment of the effect of some factors on spontaneous coal combustion. Journal of Mining Science, 1996, No. 32(6). Pp. 536-541.

5. Rosema A., Guan Y. \& Veld H. Simulation of spontaneous combustion, to study the causes of coal fires in the Rujigou Basin. Article in Fuel, 2001, No. 80(1). Pp. 7-16.

6. Wang Q.S., Guo D. \& Sun J.H. Spontaneous Combustion Prediction of Coal by C80 and ARC Techniques. Energy and Fuels, 2009, No. 23(10). Pp. 4871-4876. 7.Skochinskiy A.A. \& Ogievskiy V.M. Rudnichnye pozhary [Mine fires]. Moscow, Gornoe delo Kimmeriyskiy tsentr LLC, 2011, 375 p.

8. Portola V.A. \& Khramtsov V.I. Vliyanie primenyaemykh $v$ shahtakh sostavov na sklonnost uglya k samovozgoraniyu [Influence of the compositions used in mines on the coal liability to spontaneous combustion]. Bezopasnost Truda v Promyshlennosti - Safety in Industry, 2017, No. 2, Pp. 56-59.

9. Sin S.A., Portola V.A. \& Igishev V.G. Povyshenie effektivnosti primeneniya azota dlya bor'by s samovozgoraniem uglya $v$ shakhtakh [Improvement of nitrogen efficiency for fighting spontaneous coal ignition in the mines] Ugol' - Russian Coal Journal, 2018, No. 5, Pp. 51-57. doi: 10.18796/00415790-2018-5-51-510. Maevskaya V.M. Opredelenie vliyaniya optimalnykh utechek vozduha na process samovozgoraniya uglya pri shchitovoy sisteme razrabotki [Determination of the influence of optimal air leaks on the process of spontaneous combustion of coal under the shield mining system]. Nauchnye soobshcheniya VostNII po bezopasnosti rabot $v$ promyshlennosti - VostNII Scientific Reports on the Safety in Industry, Kemerovo, 1961. No. 2. Pp. 54-62. 11. Maevskaya V.M., Belaventsev L.P. \& Rapotsevich A.P.O dopustimoy depressii shchitovykh vyemochnykh uchastkov [On the permissible thermal drop of ventilation pressure at shield working areas]. Ugol' - Russian Coal Journal, 1968, No. 10, Pp. 57-59.

12. Maevskaya V.M., Rapotsevich A.P., Belaventsev L.P. \& Parahin P.A. Vliyanie rezhima provetrivaniya shchitovykh vyemochnykh uchastkov na ikh pozharoopasnost [Influence of shield working areas ventilation mode on their fire hazard]. Voprosy bezopasnostivugolnykh shahtakh - Safetylssues in CoalMines, Moscow, Nedra Publ., 1969, Vol. II, Pp. 147-162.

13. Baev Kh.A. Opredelenie pozharoopasnoy skorosti filtratsii vozdukha cherez ugolnye skopleniya [Determination of a fire-dangerous velocity of air filtration through coal stockpiles]. Tekhnika Bezopasnosti, Ohrana Truda iGornospasatelnoe Delo-Safety, Labor Protection and Mine Rescue, 1969, No. 11-12, Pp. 44-45. 14. Gluzberg E.I. Teplo- i massoobmen v protsesse samonagrevaniya ugolnogo skopleniya [Heat and mass transfer in the process of stockpiled coal self-heating]. Vsesoyuznyy Mezhvuzovskiy Sbornik Fizicheskie Processy Gornogo Proizvodstva - All-Union Intercollegiate Collection "Physical Processes OfMining Production", 1978, Issue 5, Pp. 66-70. 


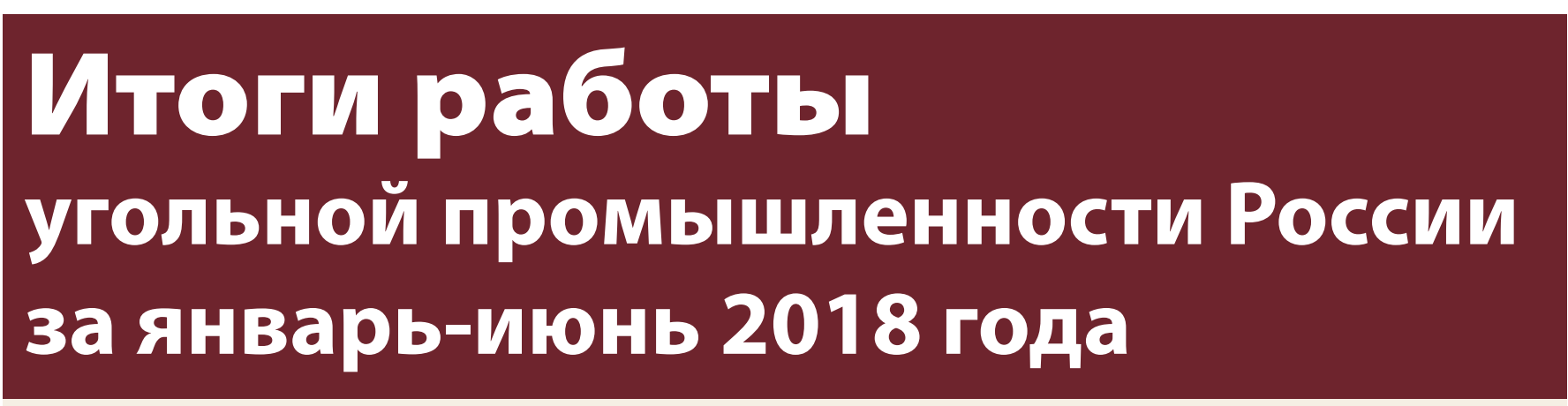

Составитель:

ТАРАЗАНОВ Игорь Геннадьевич

Горный инженер, чл.-корр. РАЭ, заместитель главного редактора журнала «Уголь», 119049, г. Москва, Россия, e-mail:ugol1925@mail.ru

Использованы данные: ФГБУ «ЦДУТЭК», Poccmama, AO «Росинформуголь», Департамента угольной и торфяной промышленности Минэнерго России, пресс-релизы компаний.
Добыча угля в России, млн $m$

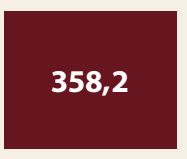

2014

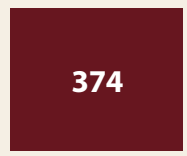

2015

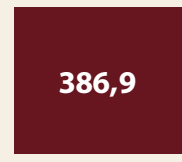

2016

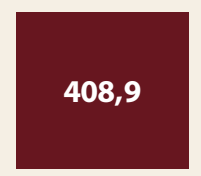

2017
210

6 мес. 2018
На основе статистических, технико-экономических и производственных показателей представлен аналитический обзор итогов работы угольной промышленности России за январь-июнь 2018 г. Обзор сопровождается диаграммами, таблицами и обширными статистическими данными. Ключевые слова: добыча угля, добыча коксующегося угля экономика, переработка угля, рынок угля, поставка, экспорт и импорт угля.

DOI: http://dx.doi.org/10.18796/0041-5790-2018-10-47-59

\section{ВВЕДЕНИЕ}

Россия является одним из мировых лидеров по производству угля, она занимает шестое место по объемам угледобычи после Китая, США, Индии, Австралии и Индонезии (на долю России приходится примерно 4,5\% мировой угледобычи) [1, 2, 3].

Фонд действующих угледобывающих предприятий России по состоянию на 01.07.2018 насчитывает 171 предприятие (шахты - 57, разрезы - 114). Переработка угля в отрасли осуществляется на 65 обогатительных фабриках и установках, а также на имеющихся в составе большинства угольных компаний сортировках.

В результате проведенной в ходе реструктуризации угольной промышленности приватизации угольных активов практически вся добыча угля осуществляется акционерными обществами с частной формой собственности.

В пределах Российской Федерации находятся 22 угольных бассейна и 129 отдельных месторождений. Добыча угля ведется в семи федеральных округах, 25 субъектах Россий- ской Федерации. В отрасли задействовано около 143 тыс. человек, а с членами их семей - около 600 тыс. человек.

В России уголь потребляется во всех субъектах Российской Федерации. Основные потребители угля на внутреннем рынке - это электростанции и коксохимические заводы. Из угледобывающих регионов самым мощным поставщиком угля является Кузнецкий бассейн - здесь производится более половины (58\%) всего добываемого угля в стране и 75\% углей коксующихся марок.

Наиболее перспективными по запасам и качеству угля, состоянию инфраструктуры и горнотехническим возможностям являются, помимо предприятий Кузбасса, также разрезы Канско-Ачинского бассейна, Восточной Сибири и Дальнего Востока, дальнейшее развитие которых позволит обеспечить основной прирост добычи угля в отрасли. С точки зрения наращивания производственного потенциала наиболее перспективными становятся районы Восточной Сибири и Дальнего Востока.

\section{ДОБЫЧА УГЛЯ}

Добыча угля в России за январь-июнь 2018 г. составила 210 млн т. Она возросла по сравнению с первым полугодием 2017 г. на 10,7 млн т, или на 5\%. Поквартальная добыча составила: в первом - 105,3 млн т; во втором 104,7 млн т.

Подземным способом добыто 52,7 млн т угля (на 0,6 млн т, или на 1\% меньше, чем годом ранее). Из них в первом квартале добыто 24,6 млн т, во втором - 28,1 млн т.
За январь-июнь 2018 г. проведено 222,8 км горных выработок (на 1,9 км, или на 1\% выше прошлогоднего уровня), в том числе вскрывающих и подготавливающих выработок - 178,4 км (на 0,8 км, или на 0,4\% меньше, чем годом ранее). При этом уровень комбайновой проходки составляет 90\% общего объема проведенных выработок.

Добыча угля открытым способом составила 157,3 млн $\boldsymbol{m}$ (на 11,4 млн т, или на 8\% выше уровня пер- 
вого полугодия 2017 г.). Из них в первом квартале добыто 80,7 млн т, во втором - 76,6 млн т. Объем вскрышных работ за январь-июнь 2018 г. составил 1061,5 млн куб. м (на
125,9 млн куб. м, или на 14\% выше объема аналогичного периода 2017 г.).

Удельный вес открытого способа в общей добыче составил 74,9\% (годом ранее было 73,2\%).

Добыча угля в России (по способам добычи), млн $m$

общая добыча

открытый способ

подземный способ

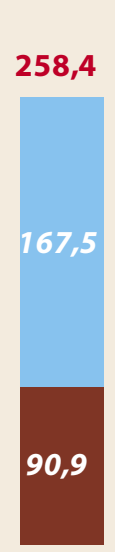

2000

\section{nodзeмный сnособ}

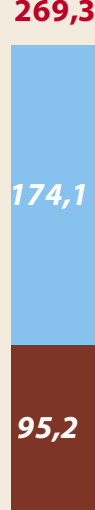

2001

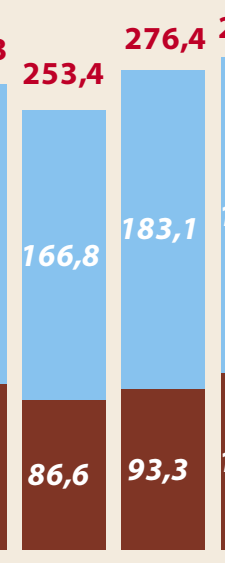

2002

2003
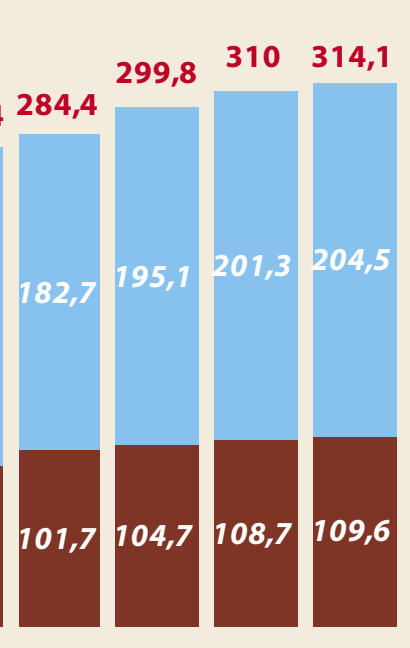

329
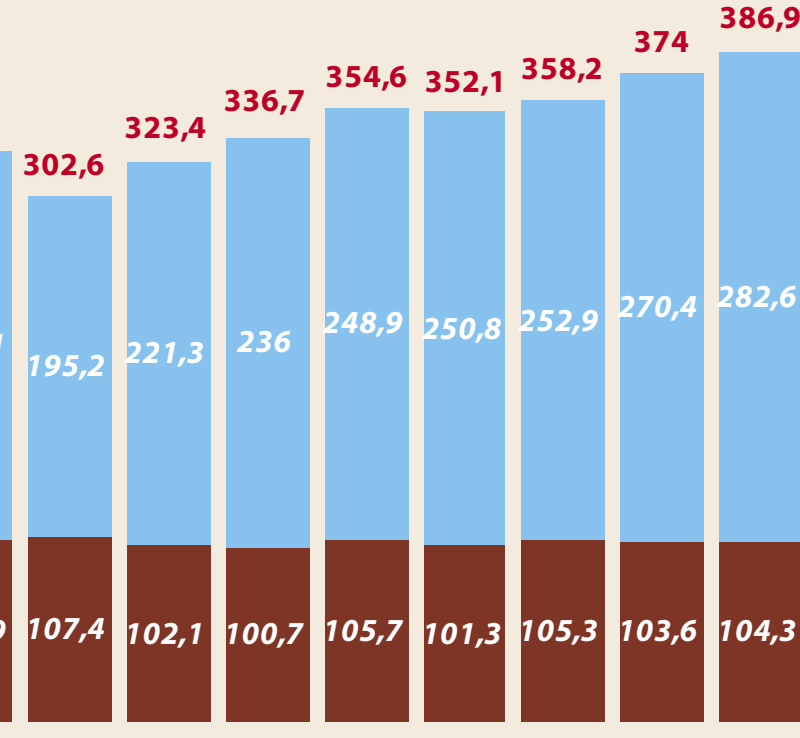

408,9

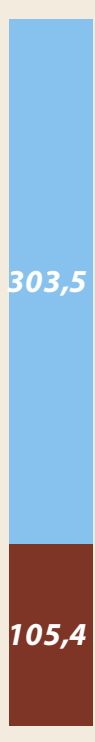

199,3

210

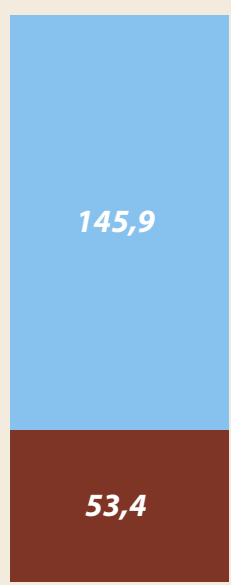

6 мес. 2017

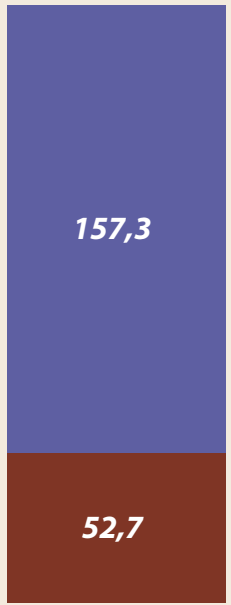

6 мec. 2018

\section{ДОБЫЧА УГЛЯ ПО ТЕРРИТОРИЯМ}

В январе-июне 2018 г. по сравнению с аналогичным периодом прошлого года добыча угля увеличилась в двух из четырех основных угольных бассейнов страны: в Кузнецком - на 4,42 млн т, или на 4\% (добыто 122,71 млн т) и в Канско-Ачинском - на 2,48 млн т, или на 13\% (добыто 21,34 млн т). Снижение отмечено в двух других бассейнах: в Печорском - на 583 тыс. т, или на 12\% (добыто 4,19 млн т) и в Донецком - на 450 тыс. т, или на 16\% (добыто 2,32 млн т).

В январе-июне 2018 г. по сравнению с первым полугодием 2017 г. добыча угля возросла в трех из семи угледобывающих экономических районов России: в
Западно-Сибирском добыто 129,56 млн т (рост на 5\%), в Восточно-Сибирском - 50,25 млн т (рост на 7\%), в Дальневосточном - 23,57 млн т (рост на 14\%). Снижение отмечено в четырех экономических районах: в Южном добыто 2,32 млн т (спад на 16\%), в Северном - 4,22 млн т (спад на 12\%), в Центральном - 86 тыс. т (спад на 29\%) и в Уральском - 28 тыс. т (спад на 95\%).

В целом по России объем угледобычи за год увеличился на 10,7 млн т, или на 5\%.

Основной вклад в добычу угля по Российской Федерации вносят Западно-Сибирский (62\%) и Восточно-Сибирский (24\%) экономические районы. 
Добыча угля (удельный вес) по основным угледобывающим экономическим районам за январь-июнь 2018 г.

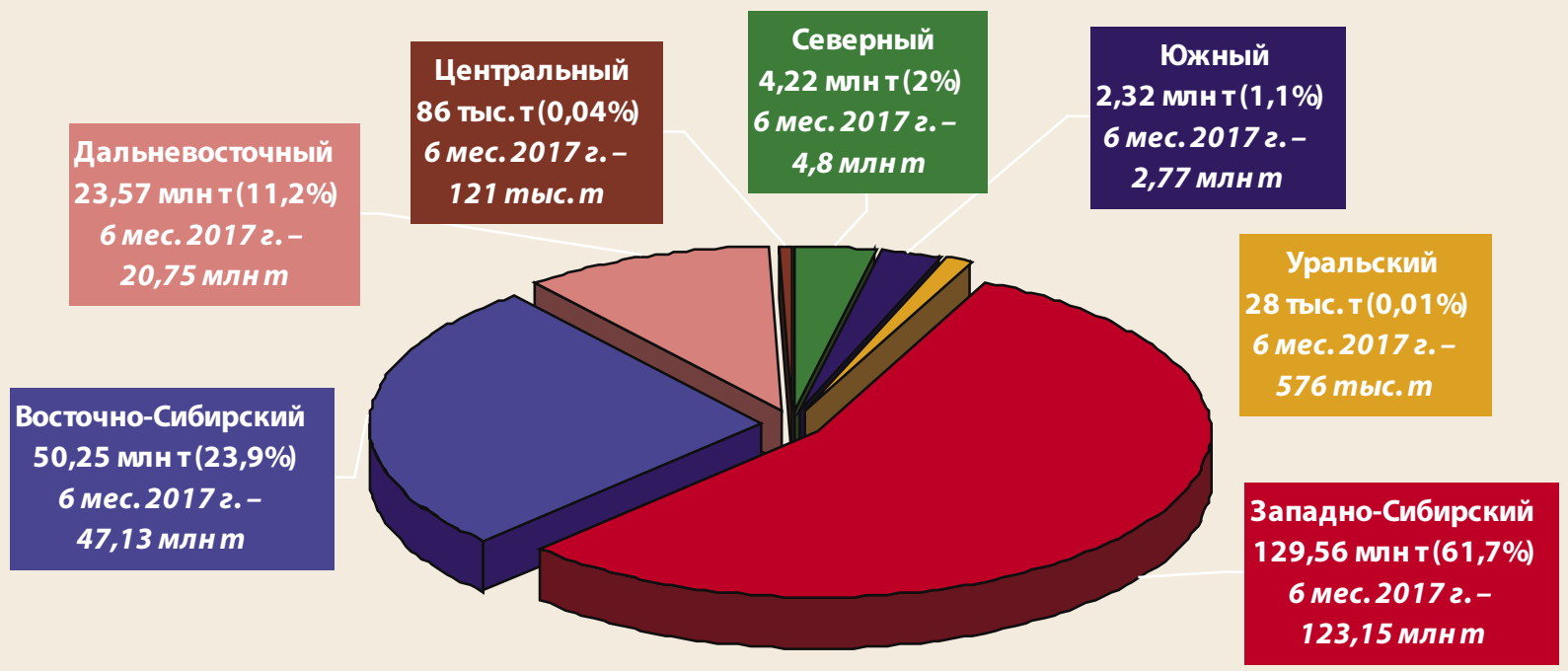

\section{Десятка наиболее крупных системообразующих предприятий (компаний) по добыче угля в России, тыс. т*} 1. AO «СУЭК»

- АО «СУЭК-Кузбасс» (Кемеровская обл.)

- Филиал АО «СУЭК-Красноярск» «Разрез Бородинский имени М.И. Щадова» (Красноярский край)

- АО «Разрез Березовский» (Красноярский край)

- $А О$ «Разрез Назаровский» (Красноярский край)

- $А О$ «Разрез Тугнуйский» (Республика

Бурятия)

- ООО «СУЭК-Хакасия» (Республика Хакасия)

- ООО «Восточно-Бейский разрез»

(Республика Хакасия)

- ОАО «Разрез Изыхский» (Республика

Хакасия)

- АО «Ургалуголь» (Хабаровский край)

- $А О$ «Разрез Харанорский» (Забайкальский край)

- ООО «Читауголь» (Забайкальский край)

- ООО «Арктические разработки»

(Забайкальский край)

- ООО «Приморскуголь» (Приморский край)

2. ОАО «УК «Кузбассразрезуголь»

- Филиал «Талдинский угольный разрез»

- Филиал «Бачатский угольный разрез»

- Филиал «Краснобродский угольный разрез»

- Филиал «Моховский угольный разрез»

- Филиал «Кедровский угольный разрез»

- Филиал «Калтанский угольный разрез»

- ООО «Шахта Байкаимская»

\section{3. АО ХК «СДС-Уголь»}

- ООО «Шахтоуправление «Майское»

(разрез «Первомайский»)

- $А O$ «Черниговец»

- ООО «Шахта Листвяжная»

\begin{tabular}{|c|c|}
\hline $\begin{array}{c}6 \text { мес. } \\
\mathbf{2 0 1 8}\end{array}$ & $\begin{array}{c}\text { К уровню } \\
\mathbf{6} \text { мес. } \\
\mathbf{2 0 1 7} \%\end{array}$ \\
\hline $\mathbf{5 5 5 8 2}$ & $\mathbf{1 0 3 , 8}$ \\
\hline 17975 & 93,0 \\
\hline 11652 & 113,5 \\
\hline
\end{tabular}

2323

117,1

2015

7261

121,9

103,6

3995

1741

663

105,3

99,6

119,4

3471

1985

574

268

1659

21941

5323

4740

3737

3357

2463

2073

248

13281

3250

2973

2765

108,3

137,1

105,7

102,3

123,4

$\mathbf{9 4 , 7}$

81,8

99,4

104,1

108,4

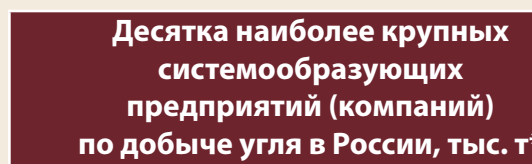

системообразующих

предприятий (компаний)

- $А О$ «Салек» (разрез «Восточный»)

- $А О$ «Прокопьевский угольный разрез»

\section{000 «Распадская угольная} компания» (ЕВРАЗ)

- ОАО «ОУК «Южкузбассуголь»

- ПАО «Распадская»

5. ОАО «Мечел-Майнинг»

- АО ХК «Якутуголь»

- ПАО «Южный Кузбасс»

- ООО «Эльгауголь»

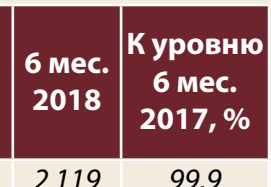

99,9

$1321 \quad 131,0$

\begin{tabular}{l|l|l}
853 & 114,3
\end{tabular}

$10753 \quad 95,8$

6. En+ Group

- ООО «Компания «Востсибуголь»

5475

5278

9691

3695

3455

2541

7664

5975

1275

- Разрез «Ирбейский» (Компания

315

- ООО «Тувинская ГРК»

99

-ОО «Разрез Ныгдинский

7531

7. ПАО «Кузбасская Топливная Компания»

8. АО «Русский Уголь»

6873

- ОАО «Красноярсккрайуголь»

2667

- $А О$ «УК «Разрез Степной»

2055

- $А О$ «Амуруголь»

1631

520

- ООО «Саяно-Партизанский»

6120

9. ЗАО «Стройсервис»

2821

- ООО «Разрез «Пермяковский

$1959 \quad 164,3$

- ООО СП «Барзасское товарищество»

$745 \quad 128,6$

- $А О$ «Разрез «Шестаки»

$293 \quad 67,9$

- 000 «Шахma № 12»

302

10.000 «УК «ЕВРАЗ МеждУреченск»

5942

3111

- $А О$ «Междуречье»

- $A O$ «Угольная компания «Южная»

1626

- $A O$ «Шахта «Большевик»

687

$518 \quad 192,3$

- АО «Шахта «Антоновская»

* Указанные компании суммарно обеспечивают $75 \%$ всего объема добычи угля в России. 
Тридиатка наиболее крупных производителей угля по итогам работы за январь-июнь 2018 г., объем добычи, тыс. $m$

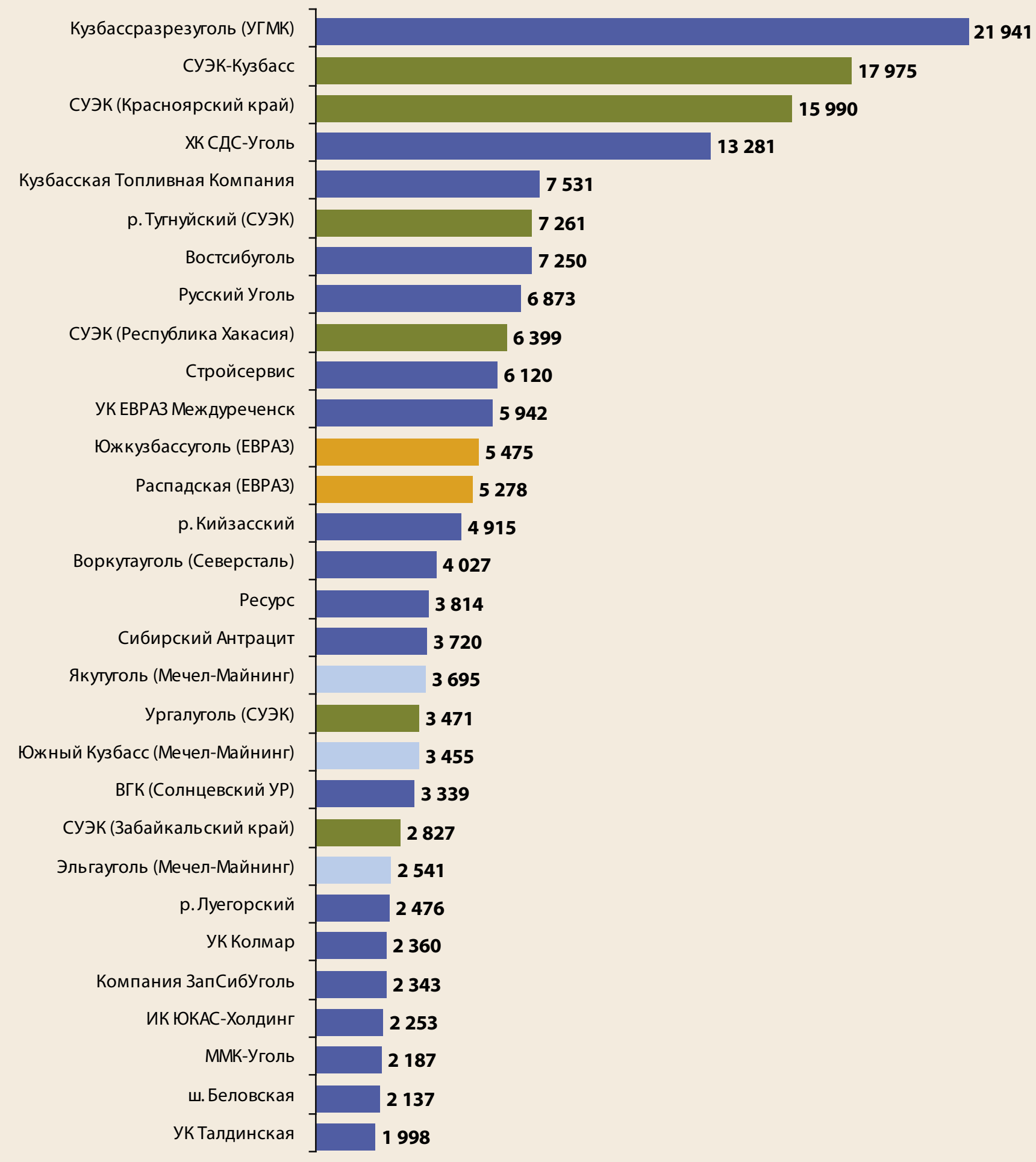

\section{ДОБЫЧА УГЛЯ ДЛЯ КОКСОВАНИЯ}

В первом полугодии 2018 г. было добыто 46,6 млн т коксующегося угля, что на 3,8 млн т, или на 9\% выше уровня января-июня 2017 2. Из них в первом квартале добыто 22,8 млн т, во втором - 23,8 млн т коксующихся углей.

Доля углей для коксования в общей добыче составила только 22\%. Основной объем добычи этих углей пришелся на предприятия Кузбасса - 75\%. Здесь было добы- то 35,2 млн т угля для коксования, что на 3,94 млн т больше, чем годом ранее (рост на 13\%). Добыча коксующегося угля в Печорском бассейне составила 4,03 млн т (6 мес. 2017 г. - 4,47 млн т; спад на 10\%). В Республике Саха (Якутия) было добыто 7,15 млн т угля для коксования (годом ранее было 6,85 млн т; рост на 4\%). В Забайкальском крае было добыто 268 тыс. т угля для коксования (6 мес. 2017 г. - 175 тыс. т; рост на 53\%). 


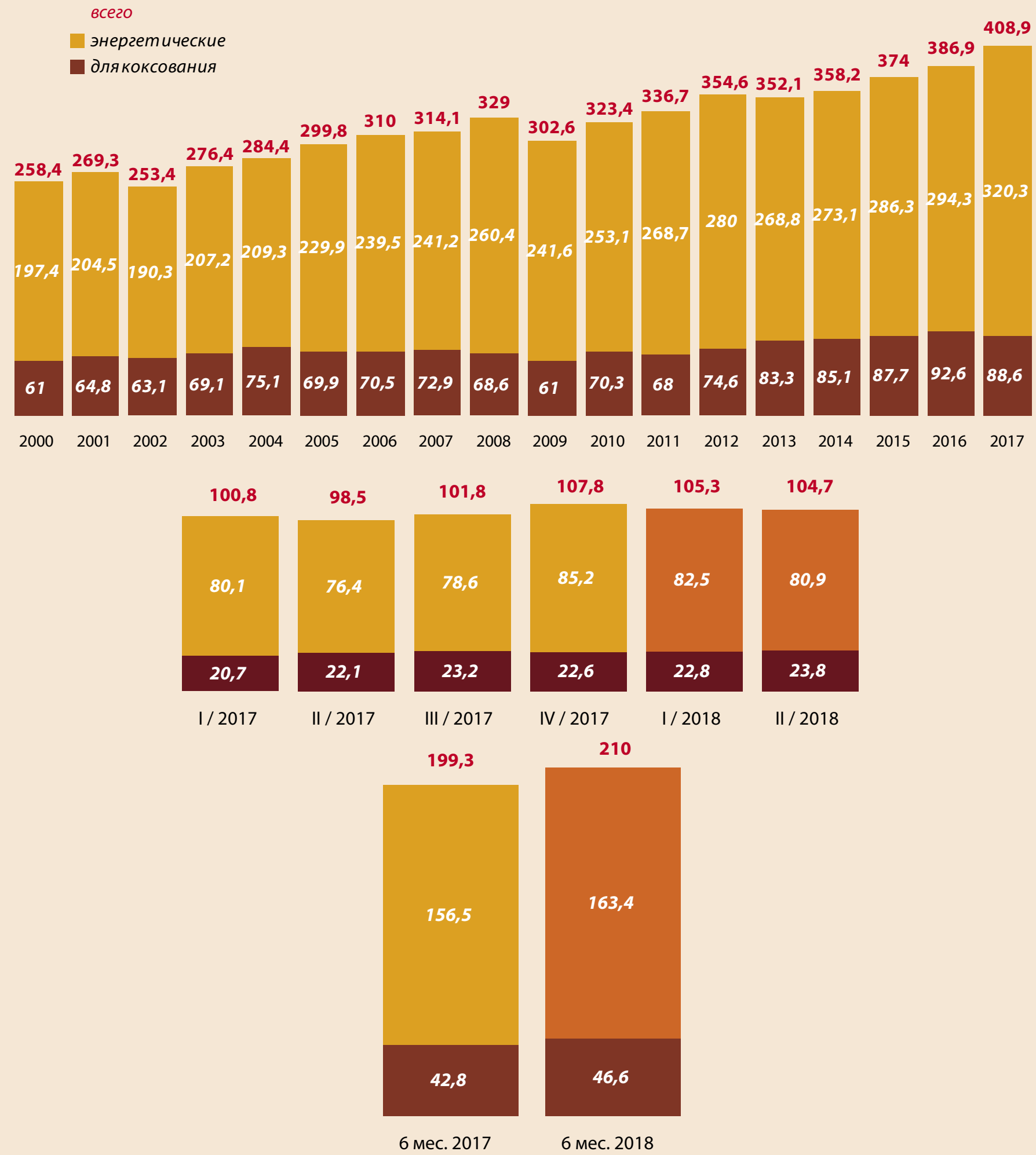

По результатам работы в январе-июне 2018 г. наиболее крупными производителями угля для коксования являются: ЕВРАЗ (10753 mыс. m, в том числе ОАО «ОУК «Южкузбассуголь» - 5475 тыс. $m$, ПАО «Распадская» - 5278 mыс. m,); ОАО «Мечел-Майнинг» (6751 mыс. m, в том числе АО ХК «Якутуголь»- 3339 тыс. m, ООО «Эльгауголь» - 1900 тыс. m, ПАО «Южный Кузбасс» - 1512 mыс. m); АО «Воркутауголь» (4027 mыс. m); АО «СУЭК» (3418 mыс. $m$, в том числе $А О$ «СУЭК-Кузбасс» - 3150 тыс. m, ООО «Арктические разработки» - 268 mыс. $m$ ); ООО «УК «ЕВРАЗ

Междуреченск» (3290 тыс. m, в том числе $A O$ «Междуречье» - 2085 mыс. $m$, АО «Шахта «Большевик» - 687 тыс. $m$, AО «Шахта «Антоновская» - 518 тыс. $m$ ); АО «УК «Кузбассразрезуголь» (3165 mыc. m); АО ХK «СДС-Уголь» (2486 mыс. m); ООО «ММК-УГОЛЬ» (2187 mыс. $\mathrm{m}$ ); ЗАО «Стройсервис» (2087 mыс. m, в том числе ООО «Разрез «Березовский» - 1365 тыс. $m$, ООО СП «Барзасское товарищество» - 555 mыс. m, ООО «Шахта №12» - 102 mыс. m, AO «Разрез «Шестаки» - 65 тыс. $m) ;$ ОАО «Шахта «Полосухинская» (1421 тыс. $m$ ). 


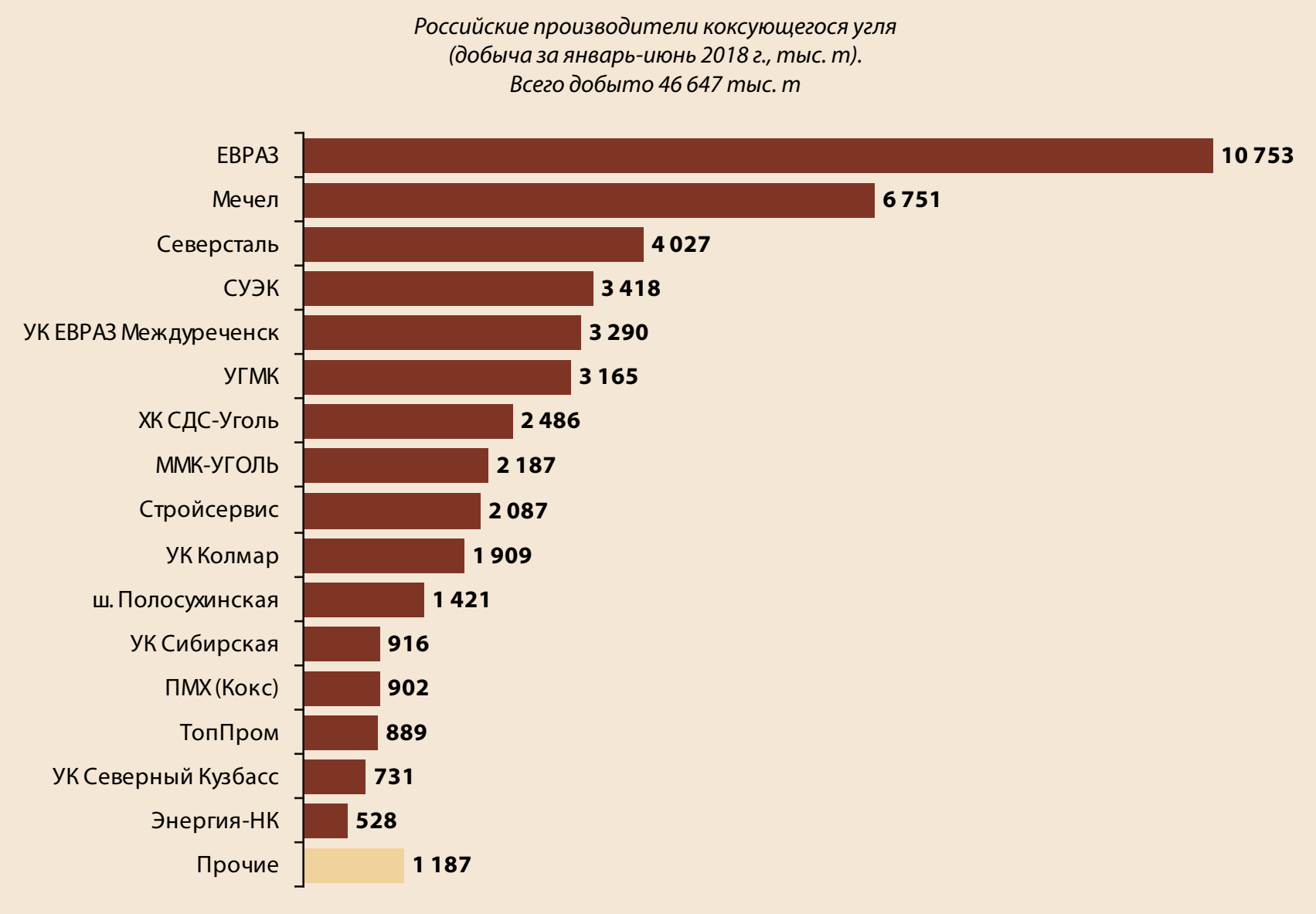

\section{ПЕРЕРАБОТКА УГЛЯ}

Общий объем переработки угля в январе-июне 20182. сучетом переработки на установкахмеханизированной породовыборки составил 99,4 млн m (на 188 тыс. т, или на 0,2\% выше уровня первого полугодия 2017 г.).

На обогатительных фабриках переработано 97,2 млн m (на 819 тыс. т, или на 1\% больше, чем годом ранее), в том числе для коксования - 44,6 млн т (на 659 тыс. т, или на 1,5\% ниже уровня первого полугодия 2017 г.).

Выпуск концентрата составил 54,5 млн т (на 287 тыс. т, или на 0,5\% меньше, чем годом ранее), в том числе для коксования - 28 млн т (на 1,16 млн т, или на 4\% ниже уровня января-июня 2017 г.).

Выпуск углей крупных и средних классов составил 8,64 млн т (на 20 тыс. т, или на 0,2\% больше, чем годом ранее), в том числе антрацитов - 688 тыс. т (на 45 тыс. т, или на 6\% ниже уровня первого полугодия 2017 г.).

Дополнительно переработано на установках механизированной породовыборки 2,18 млн $\mathbf{m}$ угля (на 631 тыс. т, или на 22\% ниже уровня первого полугодия 2017 г.).

Переработка угля на обогатительных фабриках в январе-июне 2018 г., тыс. т

\begin{tabular}{|c|c|c|c|c|c|c|}
\hline \multirow{2}{*}{$\begin{array}{c}\text { Бассейны, } \\
\text { регионы }\end{array}$} & \multicolumn{3}{|c|}{ Всего } & \multicolumn{3}{|c|}{ В том числе для коксования } \\
\hline & $\begin{array}{c}6 \text { мec. } \\
2018\end{array}$ & $\begin{array}{c}6 \text { мec. } \\
2017\end{array}$ & $\begin{array}{l}\text { к } 6 \text { мec. } \\
2017, \%\end{array}$ & $\begin{array}{c}6 \text { Mec. } \\
2018 \\
\end{array}$ & $\begin{array}{c}6 \text { Mec. } \\
2017\end{array}$ & $\begin{array}{l}\text { k } 6 \text { мec. } \\
2017, \%\end{array}$ \\
\hline Всего по России & 97238 & 96419 & 100,8 & 44627 & 45286 & 98,5 \\
\hline Печорский бассейн & 3594 & 3682 & 97,6 & 3434 & 3387 & 101,4 \\
\hline Донецкий бассейн & 1467 & 1999 & 73,4 & - & - & - \\
\hline Челябинская обл. & - & 575 & - & - & - & - \\
\hline Новосибирская обл. & 2670 & 2724 & 98,0 & - & - & - \\
\hline Кузнецкий бассейн & 66040 & 65253 & 101,2 & 35679 & 36539 & 97,6 \\
\hline Республика Хакасия & 6285 & 6294 & 99,9 & - & - & - \\
\hline Иркутская обл. & 1576 & 1391 & 113,3 & - & - & - \\
\hline Забайкальский край & 6555 & 5863 & 111,8 & - & - & - \\
\hline Республика Саха (Якутия) & 5514 & 5360 & 102,9 & 5514 & 5360 & 102,9 \\
\hline Хабаровский край & 3418 & 3212 & 106,4 & - & - & - \\
\hline Приморский край & 119 & 0 & - & - & - & - \\
\hline Сахалинская обл. & - & 66 & - & - & - & - \\
\hline
\end{tabular}


Выпуск концентрата в январе-июне 2018 г., тыс. т

\begin{tabular}{|c|c|c|c|c|c|c|}
\hline \multirow{2}{*}{$\begin{array}{c}\text { Бассейны, } \\
\text { регионы }\end{array}$} & \multicolumn{3}{|c|}{ Bcero } & \multicolumn{3}{|c|}{ В том числе для коксования } \\
\hline & $\begin{array}{l}6 \text { мec. } \\
2018\end{array}$ & $\begin{array}{l}6 \text { мec. } \\
2017\end{array}$ & $\begin{array}{l}\text { к } 6 \text { мес. } \\
2017, \%\end{array}$ & $\begin{array}{c}6 \text { мec. } \\
2018\end{array}$ & $\begin{array}{l}6 \text { мec. } \\
2017\end{array}$ & $\begin{array}{l}\text { к } 6 \text { мес. } \\
2017, \%\end{array}$ \\
\hline Всего по России & 54494 & 54781 & 99,5 & 28032 & 29196 & 96,0 \\
\hline Печорский бассейн & 1429 & 1605 & 89,1 & 1396 & 1528 & 91.4 \\
\hline Донецкий бассейн & 940 & 1115 & 84,3 & - & - & - \\
\hline Челябинская обл. & - & 2 & - & - & - & - \\
\hline Новосибирская обл. & 620 & 509 & 121,9 & - & - & - \\
\hline Кузнецкий бассейн & 39016 & 39512 & 98,7 & 23665 & 24469 & 96,7 \\
\hline Республика Хакасия & 4269 & 4227 & 101,0 & - & - & - \\
\hline Иркутская обл. & 1077 & 908 & 118,6 & - & - & - \\
\hline Забайкальский край & 2863 & 2677 & 107,0 & - & - & - \\
\hline Республика Саха (Якутия) & 2971 & 3199 & 92,9 & 2971 & 3199 & 92,9 \\
\hline Хабаровский край & 1265 & 989 & 127,9 & - & - & - \\
\hline Приморский край & 44 & 0 & - & - & - & - \\
\hline Сахалинская обл. & - & 38 & - & - & - & - \\
\hline
\end{tabular}

Выпуск углей крупных и средних классов в январе-июне 2018 г., тыс. т

\begin{tabular}{|l|c|c|c|}
\hline \multicolumn{1}{|c|}{ Бассейні, регионы } & мес. 2018 & мес. 2017 & $\mathbf{1 0 0 , 2}$ \\
\hline Всего по России & $\mathbf{8 6 3 8}$ & $\mathbf{8 6 1 8}$ & $\mathbf{2 0 1 7 , 0}$ \\
\hline Печорский бассейн & 33 & 77 & 61,4 \\
\hline Донецкий бассейн & 364 & 593 & - \\
\hline Челябинская обл. & - & 2 & 121,9 \\
\hline Новосибирская обл. & 621 & 509 & 79,5 \\
\hline Кузнецкий бассейн & 1952 & 2455 & 104,9 \\
\hline Республика Хакасия & 3575 & 3408 & 125,8 \\
\hline Иркутская обл. & 539 & 429 & 199,7 \\
\hline Республика Саха (Якутия) & 265 & 133 & 100,8 \\
\hline Амурская обл. & 24 & 23 & 127,9 \\
\hline Хабаровский край & 1265 & 989 & \\
\hline
\end{tabular}

Динамика обогащения угля на обогатительных фабриках России, млн т

$$
\begin{aligned}
& \text { всего } \\
& \text { объем обогащения энергетического угля } \\
& \text { объем обогащения коксующегося угля }
\end{aligned}
$$

155,9

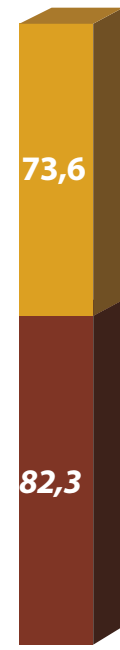

1990
104,4

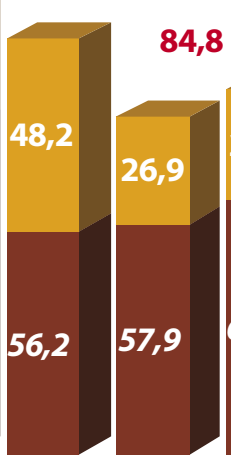

19952000

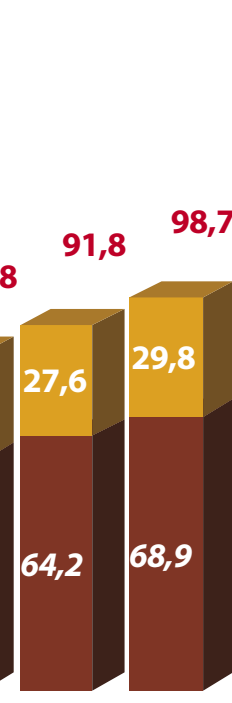

20052006

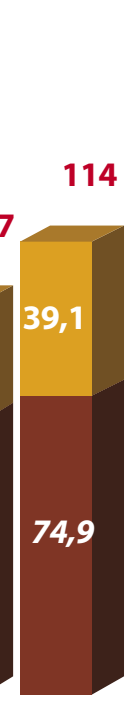

2007
114

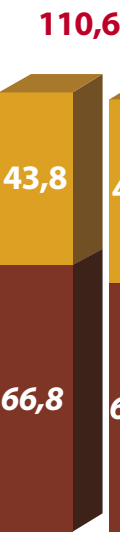

2008
124,4

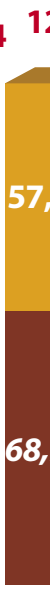

178,3 186,6 191,2

156,1

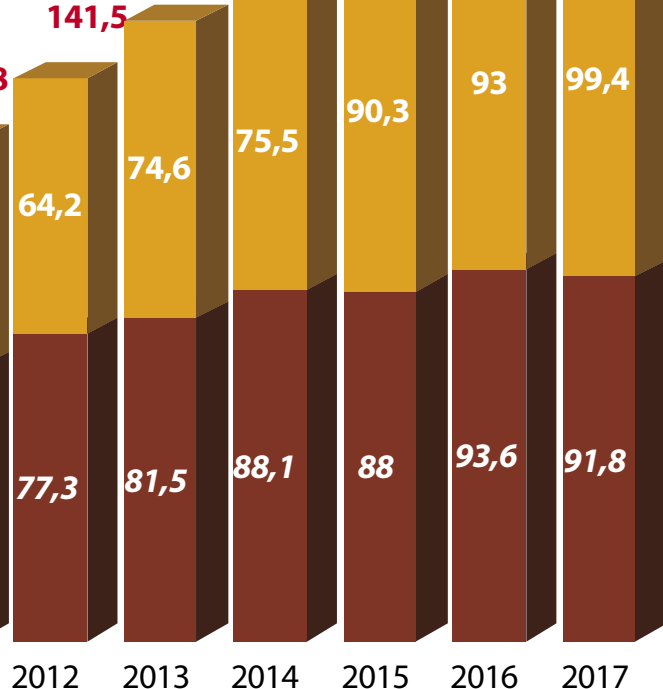


Коксующийся уголь практически весь обогащается, энергетический - только $30 \%$

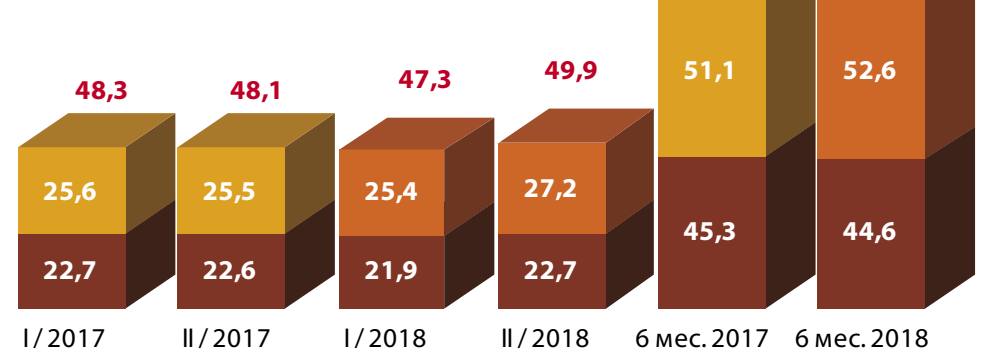

\section{ПОСТАВКА УГЛЯ}

Угледобывающие предприятия России в январеиюне 2018 г. поставили потребителям 183,6 млн т угля, что на 9 млн т, или на 5\% больше, чем годом ранее.

Из всего поставленного объема на экспорт отправлено 93,6 млн $\boldsymbol{m}$. Это на 1,7 млн т выше уровня соответствующего периода 2017 г.

Внутрироссийские поставки составили 90 млн $\mathbf{m}$ - на 7,3 млн т, или на 5\% больше, чем годом ранее.

По основным направлениям внутрироссийские поставки распределились следующим образом:
- обеспечение электростанций - 46,9 млн т (увеличились на 2,1 млн т, или на 5\% к уровню первого полугодия 2017 г.);

- нужды коксования - 15,2 млн т (уменьшились на 0,6 млн т, или на 4\%);

- обеспечение населения, коммунально-бытовые нужды, агропромышленный комплекс - 10,8 млн т (увеличились на 1,8 млн т, или на 20\%);

- остальные потребители (нужды металлургии, энергетика, РАО «РЖД», Минобороны, Минюст, МВД, Минтранс, ФПС, Атомная промышленность, Росрезерв, цементные заводы и др.) - 17,1 млн т (увеличились на 4 млн т, или на 30\%).

Поставка российских углей основным потребителям, млн $m$

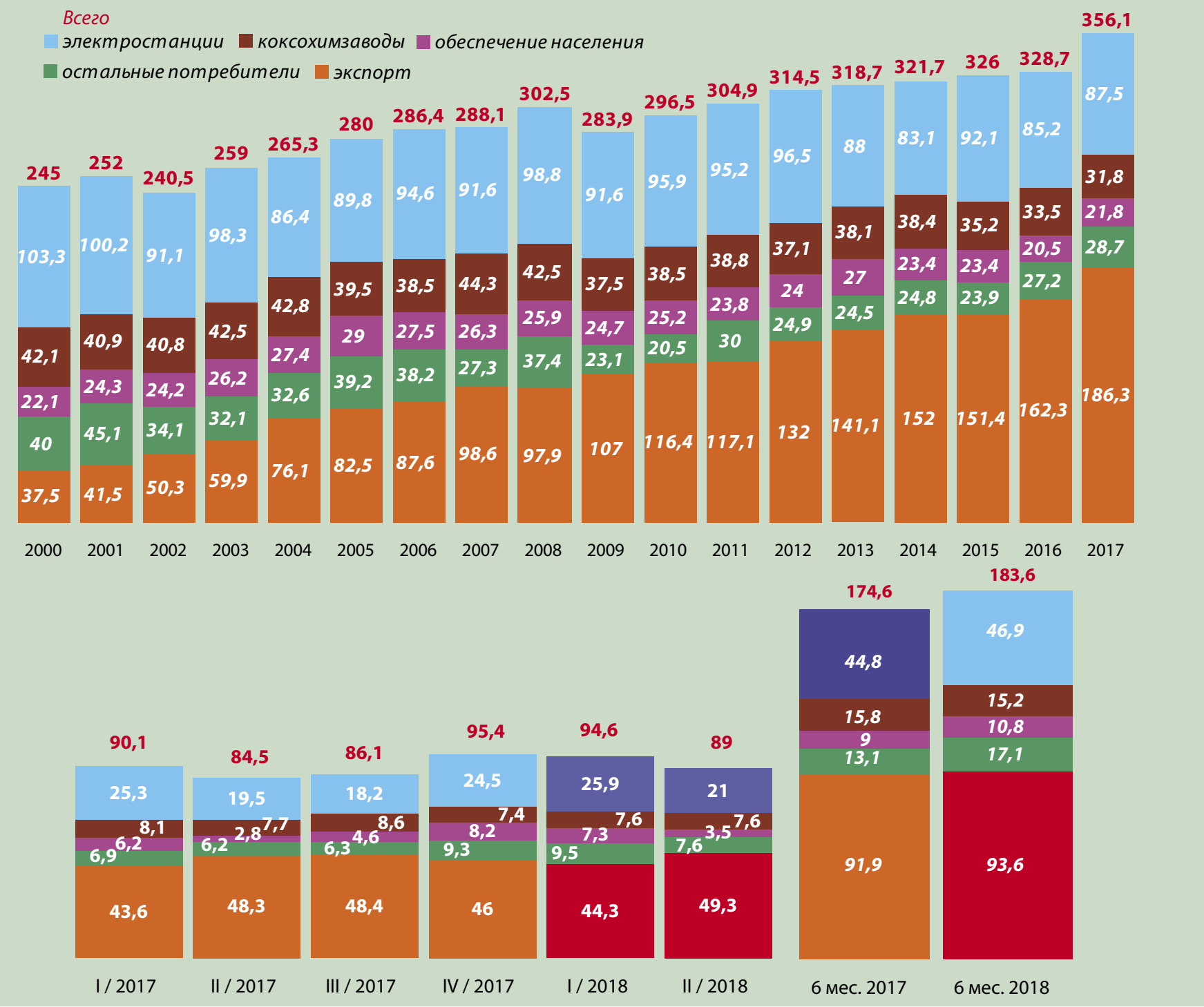


Завоз и импорт угля в Россию в январе-июне 2018 г. по сравнению с соответствующим периодом 2017 г. снизились на 1,67 млн т, или на 14\% и составили 9,95 млн т.

Завозится и импортируется в основном энергетический уголь (поставлено 9,63 млн т) и немного коксующегося (0,3 млн т). Практически весь уголь завозится из Казахстана (поставлено 9,93 млнт).

Сучетом завоза и импорта энергетического угля на российские электростанции поставлено 56,6 млн т угля (на 0,6 млн т больше, чем годом ранее). С учетом завоза и импорта коксующего- ся угля на нужды коксования поставлено 15,5 млн т (на 0,8 млн т, или на 5\% меньше, чем годом ранее).

Всего на российский рынок в первом полугодии 2018 г. поставлено с учетом завоза и импорта 99,99 млн т, что на 5,7 млн т, или на 6\% больше, чем годом ранее.

При этом доля завозимого (в том числе импортного) угля в поставках угля на российский рынок составляет $10 \%$.

\section{эКСПОРТ Угля}

Объем экспорта российского угля в январе-июне 2018 2., по отчетным данным угледобывающих компаний (по данным ФГБУ «ЦДУ ТЭК»), составил 93,6 млн m, по сравнению с аналогичным периодом 2017 г. он увеличился на 1,7 млн т, или на 2\%.

Экспорт составляет 51\% в поставках российского угля. Основная доля экспорта приходится на энергетические угли - 85,8 млн т (92\% общего экспорта углей), доля коксующихся углей (7,8 млн т) в общем объеме внешних поставок составила 8\%. Основным поставщиком угля на экспорт является Сибирский ФО (поставлено 83,6 млн т, что составляет 89\% общего экспорта), а среди экономических районов - Западно-Сибирский (поставлено 74,1 млн т, или 79\% общего экспорта), в том числе доля Кузбасса - 73\% общего экспорта (поставлено 67,95 млн т).

Из общего объема экспорта основной объем угля отгружался в страны дальнего зарубежья - 84,57 млн т (90\% общего объема экспорта), что на 161 тыс. т меньше, чем годом ранее. В страны ближнего зарубежья поставлено 9,04 млн т (10\% общего объема экспорта), что на 1,83 млн т больше, чем в январе-июне 2017 г.

В течение первого полугодия 2018 г. отмечались небольшие колебания цен на энергетический уголь как в сторону снижения, так и повышения, в пределах 3-7\%. В июне 2018 г. по сравнению с предыдущим месяцем цены на энергетический уголь на мировых торговых площадках показали положительную динамику. Рост средних экспортных цен отмечен на основных торговых площадках Австралии (FOB Ньюкасл) на +8,7\%, Турции (CIF Мраморное море, из Черного моря) на $+3,1 \%$, Турции (CIF Мраморное море, из Балтии) на +3,2\%, Японии (CIF Восточ-
Динамика экспорта российского угля по видам углей, млн $m$ 186,3

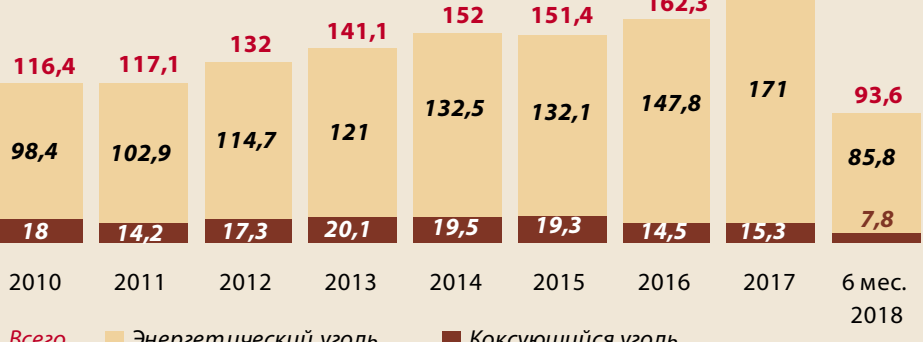

Удельный вес экономических районов России в экспортных поставках угля в январе-июне 2018 г.

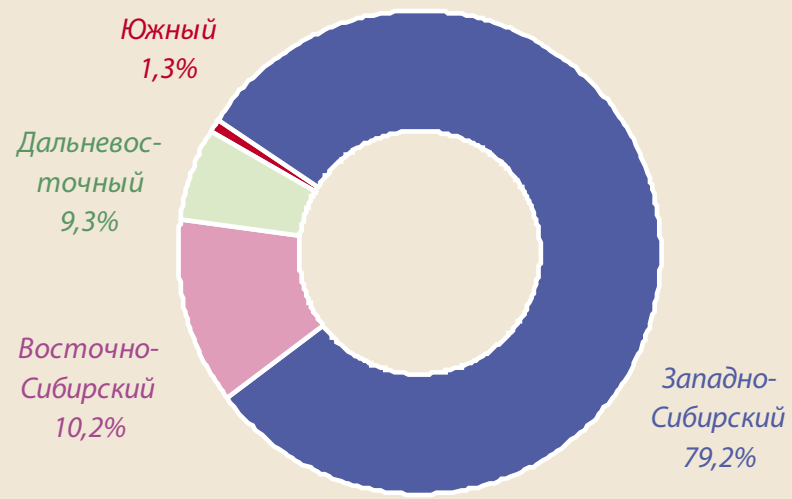

ное побережье) на $+8,0 \%$, ЮАР (FОВ Ричардс Бей) на $+9,7 \%$, Колумбии (FОВ Боливар) на $+6,38 \%$ и Европы (CIF APA) на $+7,9 \%$.

\section{Экспортные цены на уголь в 2018 г., дол. США за тонну} (по данным Металл Эксперт)

\begin{tabular}{|c|c|c|c|c|c|c|}
\hline Направления & Янв. & Февр. & Март & Anp. & Май & Июнь \\
\hline \multicolumn{7}{|c|}{ Энергетический уголь } \\
\hline FOB Рига & 89 & 81 & 74 & 76 & 83 & 88 \\
\hline FОВ Восточный & 104 & 105 & 96 & 85 & 105 & 110 \\
\hline Австралия, FOB Ньюкасл & 107 & 105 & 98 & 93 & 104 & 113 \\
\hline ЮАР, FOB Ричардс Бей & 97 & 94 & 94 & 93 & 102 & 104 \\
\hline Европа, CIF APA & 95 & 85 & 79 & 81 & 89 & 96 \\
\hline Япония, CIF Восточное побережье & 105 & 110 & 97 & 88 & 95 & 101 \\
\hline Турция, CIF Мраморное море, из Черного моря & 105 & 100 & 94 & 93 & 97 & 100 \\
\hline Турция, CIF Мраморное море, из Балтии & 103 & 97 & 91 & 90 & 95 & 98 \\
\hline Колумбия, FOB Боливар & 86 & 82 & 78 & 79 & 82 & 87 \\
\hline \multicolumn{7}{|c|}{ Твердый коксующийся уголь } \\
\hline Австралия, FOB Квинсленд & 239 & 235 & 230 & 191 & 184 & 198 \\
\hline \multicolumn{7}{|c|}{ Кокс металлургический } \\
\hline Китай, FOB & 345 & 366 & 362 & 333 & 329 & 360 \\
\hline
\end{tabular}




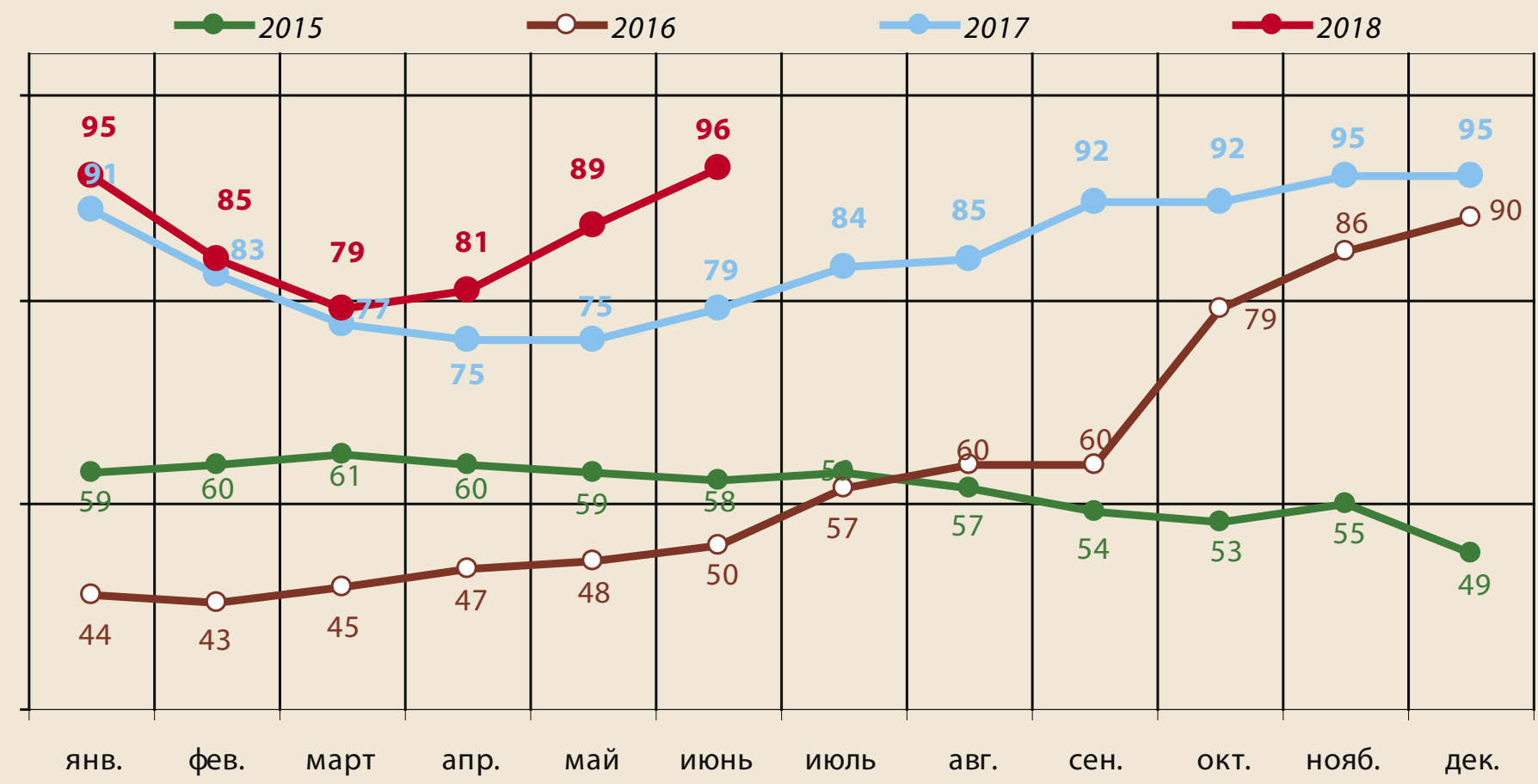

Общий объем вывезенного российского угля в январе-июне 2018 2. по данным ОАО «РЖД» составил 103,64 млн т, в том числе через морские порты отгружено 67,95 млн m (65,6\% общего объема вывоза).

Удельный вес поставок российского угля в январе-июне 2018 г. по сравнению с аналогичным периодом 2017 г. увеличился через порты северного направления - на 1,5\% и восточного направления - на 0,1\%, снижение произошло в портах южного направления - на 0,4\% и западного направления - на 1,2\%.

Объемы поставок угля через российские порты в январе-июне 2018 г. по сравнению с аналогичным периодом 2017 г. увеличились на 5,07 млн т, или на 8,1\%, в том числе через порты восточного направления - на 2,81 млн т (на 8,3\%), северного направления - на 1,62 млн т (на 21,3\%), южного направления - на 0,33 млн т (на 2\%) и западного направления (Балтика) - на 0,31 млн т (на 2,8\%).

Объемы поставок российского угля через пограничные переходы, по данным ОАО «РЖД», в январе-июне 2018 2. по сравнению с аналогичным периодом 2017 2. увеличились на 25,3\% и составили 35,69 млн $m$ (34,4 \% общего объема вывоза).

Поставка российского угля сухопутным путем осуществляется в основном через пограничные переходы Центрального, Северо-Западного и Дальневосточного федеральных округов (около 92,3\% общей поставки сухопутным путем в первом полугодии 2018 г.). Увеличились по сравнению с январем-июнем 2017 г. поставки через погра-

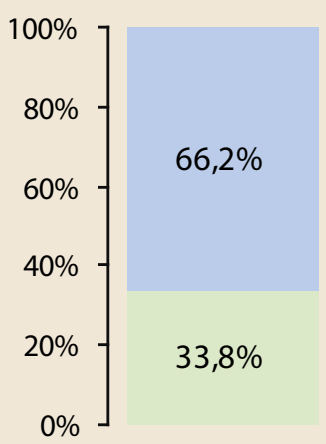

6 мес. 2014 ничные переходы Соловей (+1\%), Мамоново (+34,2\%), Кулунда (+34,12\%), Локоть $(+43,2 \%)$, Мыс Астафьева (+35,2\%), Гродеково (+74,1\%), Камыш-Экспорт (+4,8\%). В 2 раза увеличились объемы перевалки через пограничные переходы Суземка, Забайкальск, Красное, Злынка. Снизились объемы экспорта российского угля через пограничные переходы Заречная $(-24,6 \%)$, Веселое $(-14,8 \%)$, Рудня $(-12,7 \%)$, Скангали (-49\%).

В России крупнейшими компаниями-экспортерами угля выступают: $\mathrm{AO}$ «СУЭК», $\mathrm{AO}$ «УК «Кузбассразрезуголь», АО ХК «СДС-Уголь», ПАО «Кузбасская Топливная Компания» ОАО «Мечел-Майнинг» и др.; они же являются и крупнейшими поставщиками энергетических углей на экспорт. Основными поставщиками коксующихся углей на экспорт являются: $\mathrm{AO} X \mathrm{XK}$ «якутугль» (ОАО «Мечел-Майнинг»), АО «СУЭК-Кузбасс», ООО «Распадская угольная компания» (ЕВРАЗ), АО «УК «Кузбассразрезуголь» (УГМК), ООО «УК «ЕВРАЗ Междуреченск» и др.

Структура поставок российского угля через порты и пограничные переходы в январе-июне 2014-2018 г2.
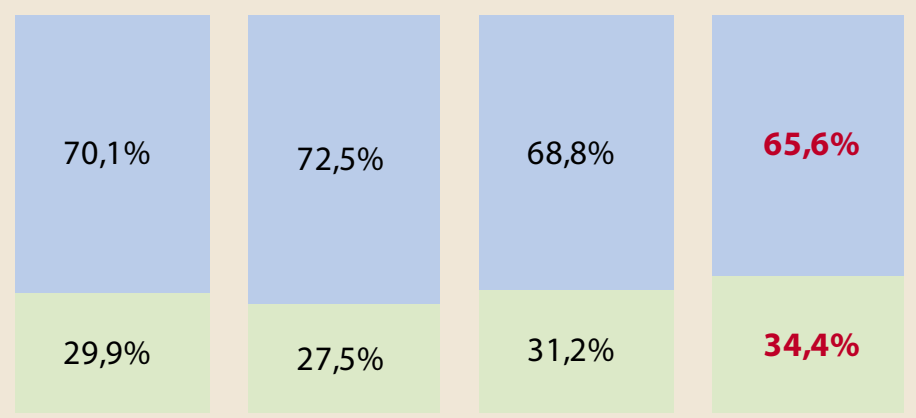

6 мес. 2015

6 мес. 2016

6 мес. 2017

6 мес. 2018 
Экспорт российского угля в январе-июне 2018 г., тыс. т

(по отчетным данным угледобывающих компаний)

\begin{tabular}{|c|c|c|c|c|c|}
\hline $\begin{array}{c}\text { Крупнейшие } \\
\text { экспортеры угля }\end{array}$ & $\begin{array}{l}6 \mathrm{mec} . \\
2018\end{array}$ & $\begin{array}{l}\text { к } 6 \text { мес. } \\
2017, \%\end{array}$ & $\begin{array}{c}\text { Крупнейшие } \\
\text { страны-импортеры* }\end{array}$ & $\begin{array}{l}6 \mathrm{mec} . \\
2018\end{array}$ & $\begin{array}{l}\text { к } 6 \text { мес. } \\
2017, \%\end{array}$ \\
\hline$A O$ «СУЭК» & 22744 & 97,3 & Япония & 17453 & 96,2 \\
\hline АО «УК «Кузбассразрезуголь» & 14004 & 92,3 & Великобритания & 13203 & 99,5 \\
\hline АО ХК «СДС-Уголь» & 10108 & 89,2 & Китай & 9056 & 90,2 \\
\hline ПАО «Кузбасская ТК» & 5431 & 134,2 & Республика Корея & 5581 & 82,5 \\
\hline ОАО «Мечел-Майнинг»: & 4422 & 83,2 & Украина & 5498 & 134,8 \\
\hline - ПАО «Южный Кузбасс» & 1896 & 91,2 & Польша & 5139 & 169,3 \\
\hline - АО ХК «Якутуголь» & 1660 & 63,9 & Турция & 2666 & 81,0 \\
\hline - ООО «Эльгауголь» & 866 & 136,4 & Латвия & 2580 & 103,5 \\
\hline АО «Сибирский Антрацит» & 4074 & 123,9 & Швейцария & 2034 & 238,7 \\
\hline ООО «Распадская УК» & 3652 & 132,7 & Финляндия & 1779 & 50,6 \\
\hline ООО «Ресурс» & 3348 & 118,0 & Румыния & 1319 & 218,0 \\
\hline ООО «Разрез Кийзасский» & 3230 & 109,8 & Германия & 1277 & 845,7 \\
\hline $\mathrm{OOO} « \mathrm{~B} Г К »$ & 2446 & 152,7 & Словакия & 737 & 133,7 \\
\hline ООО «Разрез Восточный» & 2074 & 137,0 & Индия & 601 & 62,5 \\
\hline ЗАО «Стройсервис» & 1653 & 126,8 & Бельгия & 587 & 49,9 \\
\hline АО «Талтэк» & 1367 & 107,6 & Испания & 580 & 81,9 \\
\hline АО «Русский Уголь» & 1286 & 92,3 & Таиланд & 440 & 100,7 \\
\hline ООО «УК Талдинская» & 1207 & 73,5 & Тайвань & 388 & 144,0 \\
\hline ООО «УК «ЕВРАЗ МеждуреченсК» & 1119 & 92,3 & Литва & 292 & 198,4 \\
\hline ООО «Сибэнергоуголь» & 900 & 113,3 & Болгария & 283 & 75,2 \\
\hline
\end{tabular}

* Без учета части экспортных данных ООО «Тувинская ГРК» и некоторых филиалов АО «СУЭК».

Основные экспортеры российского угля в январе-июне 2018 г., тыс. m (всего экспортировано 93612 тыс. m)

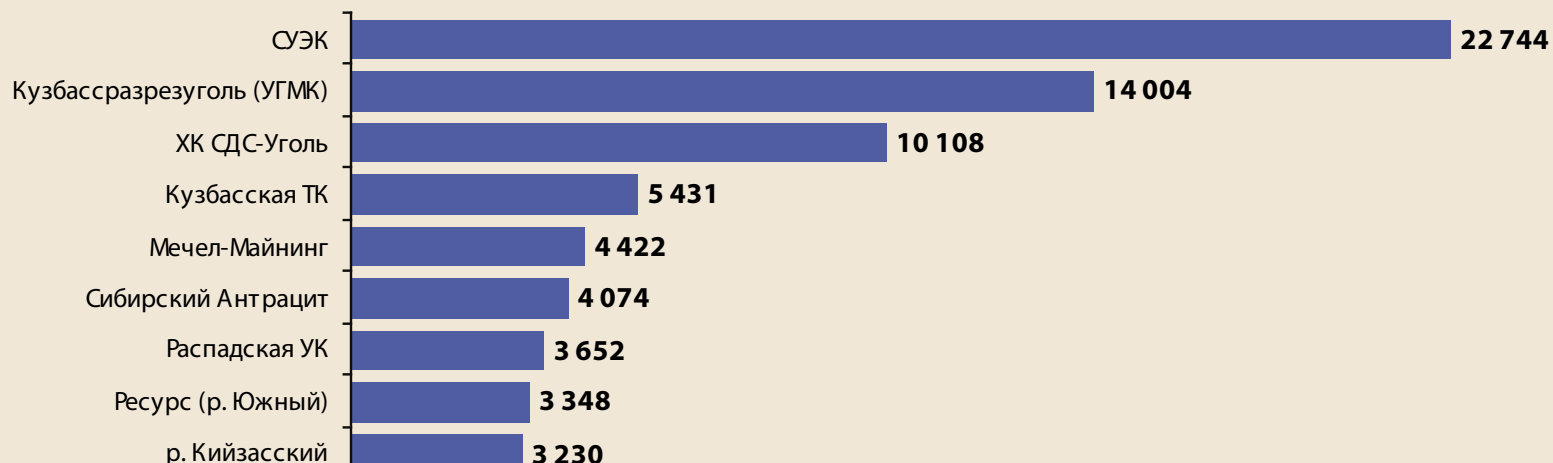

Российский уголь экспортируется 70 стран. При этом основная часть (90\%) российского углеэкспорта приходится на страны дальнего зарубежья.

Экспорт российского угля в январе-июне 2018 г., по данным ФТС России, составил 99,9 млн т, что на 7,9 млн т или 8,6\% больше, чем годом ранее.

Лидерами среди стран-импортеров российского угля по итогам первого полугодия 2018 г., по данным ФТС России, являются: Китай (импортировано 12,88 млн т), Республика Корея (12,84 млн т), Япония (8,13 млн т), Нидерланды (6,86 млн т), Турция (6,55 млн т), Великобритания (6,37 млн т), Польша (6,18 млн т), Украина (6,17 млн т), Тайвань (Китай, 5,26 млн т), Германия (4,63 млн т), Румыния (2,28 млн т), Индия (1,97 млн т), Малайзия (1,79 млн т), Испания (1,61 млн т), Латвия (1,55 млн т), Италия (1,43 млн т), Франция (1,26 млн т), Марокко (1,2 млн т), Вьетнам (994 тыс. т), Финляндия (993 тыс. т), Бразилия (950 тыс. т), Дания (861 тыс. т), Израиль (835 тыс. т), Словакия (762 тыс. т), Гонконг (539 тыс. т), Болгария (499 тыс. т), Бельгия (431 тыс. т), Пакистан (397 тыс. т), Филиппины (333 тыс. т), Таиланд (330 тыс. т). 
Динамика экспорта и завоза (импорта) угля по России, млн т

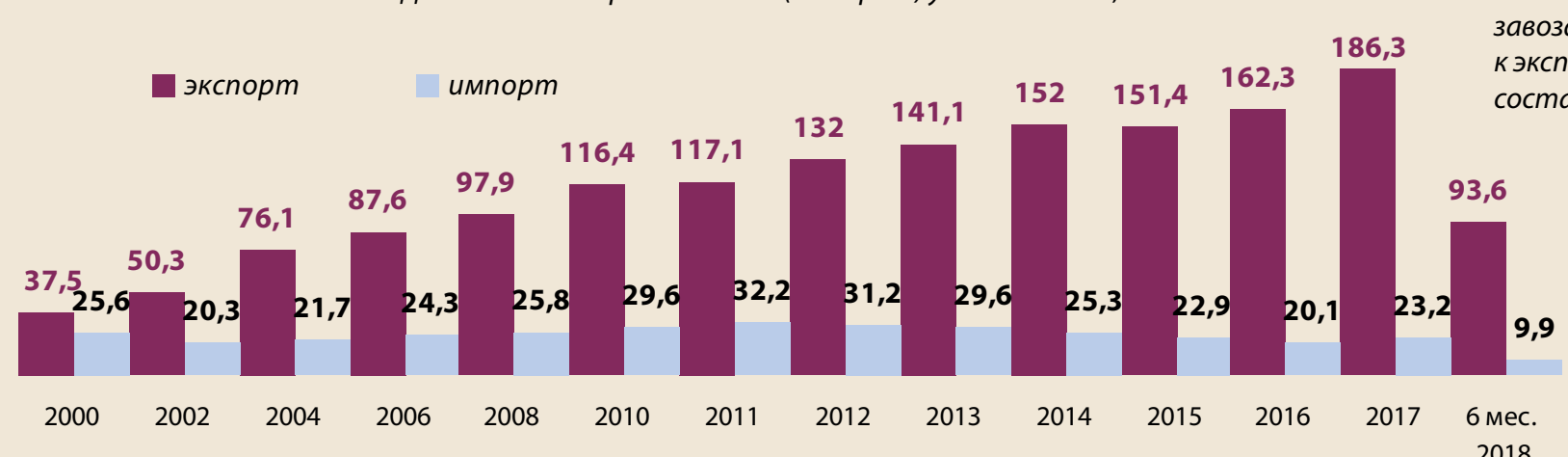

Доля экспорта в объемах поставки российского угля, \%

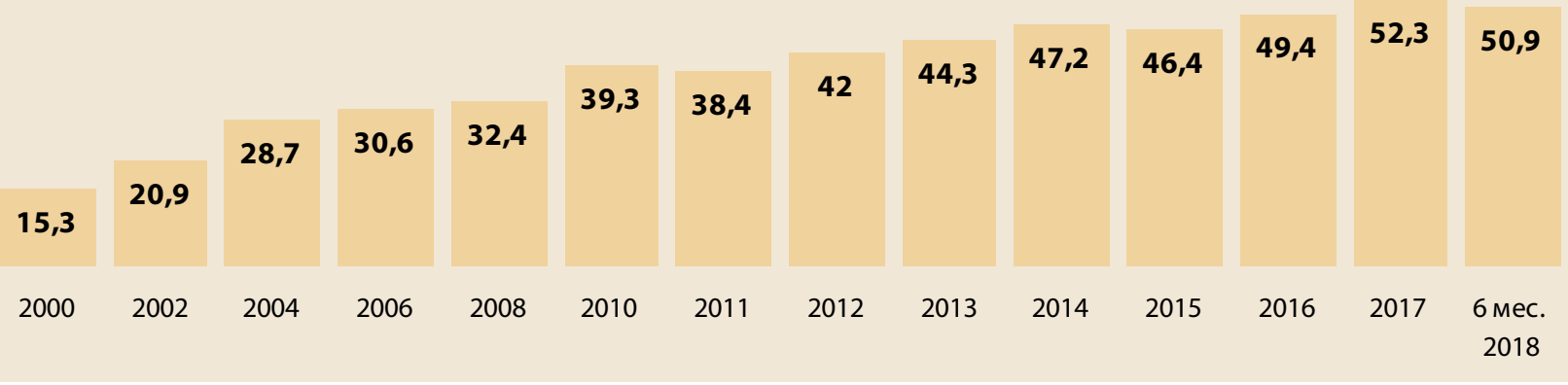

\section{PEЗßOME}

Основные показатели работы угольной отрасли России за январь-июнь 2018 г.

\begin{tabular}{|c|c|c|c|}
\hline Показатели & $\begin{array}{l}6 \text { Mec. } \\
2018 \text { r. }\end{array}$ & $\begin{array}{l}6 \text { Mec. } \\
2017 \text { r. }\end{array}$ & $\begin{array}{c}\text { К уровню } \\
6 \text { мес. } 2017 \text { г., \% }\end{array}$ \\
\hline Добыча угля, по данным Росстата, всего, тыс. т & 213815 & 199988 & 106,9 \\
\hline Добыча угля, по данным ЦДУ ТЭК, всего, тыс. т: & 210042 & 199294 & 105,4 \\
\hline - подземным способом & 52712 & 53355 & 98,8 \\
\hline - открытым способом & 157330 & 145939 & 107,8 \\
\hline Добыча угля на шахтах, тыс. т & 52874 & 53211 & 99,4 \\
\hline Добыча угля на разрезах, тыс. т & 157168 & 146083 & 107,6 \\
\hline Добыча угля для коксования, тыс. т & 46647 & 42771 & 109,1 \\
\hline Переработка угля, всего тыс. т: & 99424 & 99237 & 100,2 \\
\hline - на фабриках & 97238 & 96419 & 100,8 \\
\hline - на установках механизированной породовыборки & 2186 & 2818 & 77,6 \\
\hline Поставка российских углей, всего тыс. т & 183652 & 174626 & 105,2 \\
\hline - из них потребителям России (по данным ЦДУ ТЭК) & 90040 & 82682 & 108,9 \\
\hline - экспорт угля (по данным ЦДУТЭК) & 93612 & 91944 & 101,8 \\
\hline Экспорт угля, по данным ФТС России, тыс. т & 99918 & 91996 & 108,6 \\
\hline Экспорт угля, по данным ОАО «РЖД», тыс. т & 103643 & 91371 & 113.4 \\
\hline Завоз и импорт угля, тыс. т & 9950 & 11624 & 85,6 \\
\hline Поставка угля потребителям России с учетом завоза и импорта, тыс. т & 99990 & 94306 & 106,0 \\
\hline Средняя численность работников предприятий угледобычи и переработки, чел. & 142633 & 138514 & 102,9 \\
\hline Среднесписочная численность работников по основному виду деятельности, чел. & 137540 & 133111 & 103,3 \\
\hline $\begin{array}{l}\text { Среднесписочная численность рабочих по добыче угля (квартальная, } \\
\text { предварительные данные), чел.: }\end{array}$ & 88731 & 84601 & 104,9 \\
\hline - на шахmax & 38233 & 36925 & 103,5 \\
\hline - наразрезах & 50498 & 47676 & 105,9 \\
\hline $\begin{array}{l}\text { Среднемесячная производительность труда рабочего по добыче угля (кварталь- } \\
\text { ная), т }\end{array}$ & 340 & 327 & 104,0 \\
\hline - на шахтах & 231,3 & 202,7 & 114,1 \\
\hline - наразрезах & 422,3 & 423,3 & 99,8 \\
\hline Среднемесячная заработная плата одного работника, руб. & 54307 & 49730 & 109,2 \\
\hline Среднесуточная добыча угля из одного действующего очистного забоя, т & 4747 & 4871 & 97,5 \\
\hline Среднесуточная добыча угля из одного комплексно-механизированного забоя, т & 5035 & 5208 & 96,7 \\
\hline Проведение подготовительных выработок, тыс. м & 222,8 & 220,9 & 100,9 \\
\hline Вскрышные работы, тыс. куб. м & 1061466 & 935503 & 113,5 \\
\hline
\end{tabular}




\section{Список литературы}

1. Яновский А.Б. Основные тенденции и перспективы развития угольной промышленности России //Уголь. 2017. № 8. C. 10-14. doi: 10.18796/0041-5790-2017-8-10-14. URL: http://www.ugolinfo.ru/Free/082017.pdf (дата обращения: 15.06.2018).

2. Таразанов И.Г. Итоги работы угольной промышленности России за январь-декабрь 2017 года // Уголь. 2018.
№ 3. C. 58-73. doi: 10.18796/0041-5790-2018-3-58-73. URL: http://www.ugolinfo.ru/bgdev/Jour/032018.pdf (дата обращения: 15.06.2018).

3. Глинина О.И. Угольная промышленность в России: 295 лет истории и новые возможности // Уголь. 2017. № 10. C. 4-11. URL: http://www.ugolinfo.ru/Free/102017.pdf (дата обращения: 15.06.2018).

UDC 622.33(470):658.155 @ I.G. Tarazanov, 2018

ANALYTICAL REVIEW

ISSN 0041-5790 (Print) • ISSN 2412-8333 (Online) • Ugol' - Russian Coal Journal, 2018, № 10, pp. 47-59

Title

Russia's coal industry performance for January - June, 2018

DOI: http://dx.doi.org/10.18796/0041-5790-2018-10-47-59

\section{Author}

Tarazanov I.G. ${ }^{1}$

${ }^{1}$ Ugol' Journal Edition LLC, Moscow, 119049, Russian Federation

\section{Authors' Information}

Tarazanov I.G., Mining Engineer, General Director, Deputy Chief Editor of the Russian Coal Journal (Ugol'), e-mail: ugol1925@mail.ru

\section{Abstract}

The paper provides an analytical review of Russia's coal industry performance for January-June, 2018 on the basis of statistical, technical \& economic and production figures. The review contains diagrams, tables and comprehensive statistical data.

\section{Keywords}

Coal production, Economy, Efficiency, Coal processing, Coal market, Supply, Coal exports and imports.

References
1. Yanovsky A.B. Osnovnye tendentsii i perspektivy razvitiya ugol'noy promyshlennosti Rossii [Main trends and prospects of the coal industry development in Russia]. Ugol' - Russian Coal Journal, 2017, No. 8, pp. 10-14. doi: 10.18796/0041-5790-2017-8-10-14. Available at: http://www.ugolinfo.ru/ Free/082017.pdf (accessed 15.06.2018).

2. Tarazanov I.G. Itogy raboty ugol'noy promishlennosty Rossii za yanvar dekabr 2017 [Russia's coal industry performance for January - December, 2017]. Ugol' - Russian Coal Journal, 2018, No. 3, pp. 58-73. doi: 10.18796/00415790-2018-3-58-73. Available at: http://www.ugolinfo.ru/bgdev/Jour/032018. pdf (accessed 15.06.2018).

3. Glinina O.I. Ugol'naya promyshlennost'v Rossii: 295 let istorii i novye vozmozhnosti [The coal industry in Russia: 295 year history and new opportunities]. Ugol' - Russian Coal Journal, 2017, No. 10, pp. 4-11. Available at: http:// www.ugolinfo.ru/Free/102017.pdf (accessed 15.06.2018).

\section{Каталог выставки «Люди Угля» стал лауреатом авторитетного конкурса The Society of Typographic Arts}

Каталог выставки «Люди Угля» стал одним из победителей конкурса The Society of Typographic Arts (STA) 100 competition в США.

Ежегодно жюри этого авторитетного конкурса со штаб-квартирой в Чикаго отбирает сотню лучших в мире проектов в области типографики и коммуникационного дизайна. По результатам 2018 года в число лучших работ включен каталог выставки «Люди Угля» - фотопроекта, созданного фотографом Максимом Мармуром по заказу AO «Сибирская угольная энергетическая компания» (СУЭК).

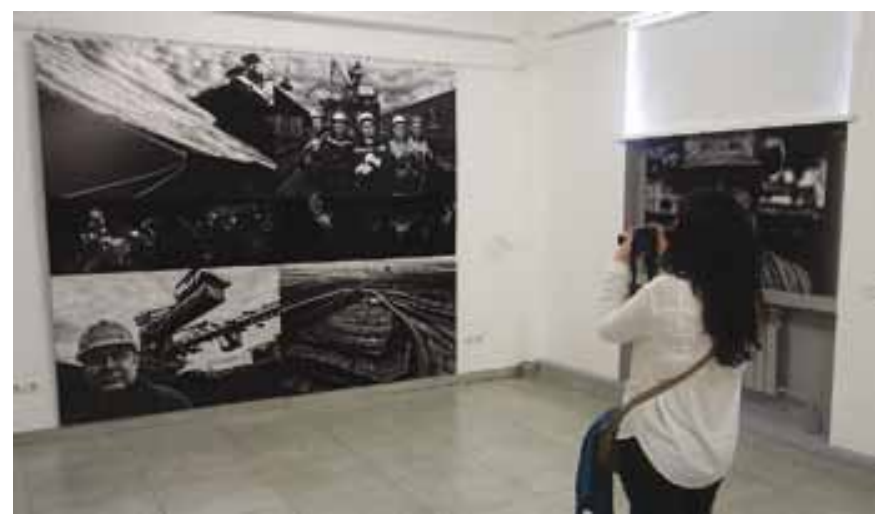

Впервые фотографии из проекта «Люди угля» были показаны в 2016 г. на Международном фестивале фотографии PhotoVisa, Россия. В апреле 2017 г. они были представлены на Итальянском фотографическом профессиональном форуме FIOF в Орвието и совершили турне по другим городам Италии. В сентябре 2017 г. «Люди угля» стали финальным аккордом экспозиции выставки «Гордость России - шахтеры», посвященной юбилею празднования Дня шахтера, которая прошла в Центральном доме художника в Москве. В 2018 г. выставка «Люди угля» прошла в Кузбассе, Хакасии, Красноярском крае, в Китае.

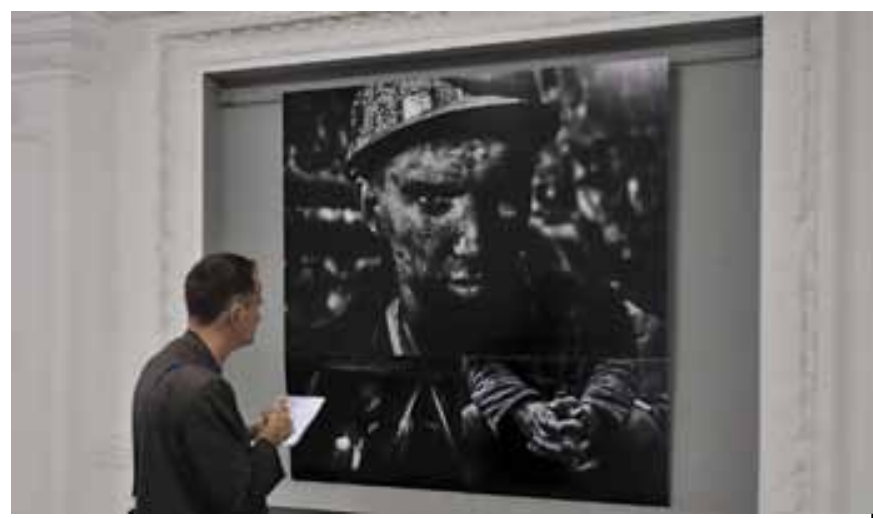




\section{Повышение производительности, качества и эффективности труда - основа экономичности и конкурентоспособности угледобывающих предприятий}

\section{пОПОВ Владимир Николаевич}

Доктор экон. наук, профессор, тел.: +7 (916) 953-50-74,

e-mail:220145@mail.ru

\section{ГРИБИН Юрий Георгиевич \\ Доктор экон. наук, профессор, тел.: +7 (910) 471-42-08, \\ e-mail:ephimovaga@mail.ru}

\section{ГАРКАВЕНКО Андрей Николаевич \\ Доктор экон. наук, САО «Геополис», 119017, г. Москва, Россия, тел.: +7 (495) 223-33-63, \\ e-mail:info@geopolis.ru}

\section{Доктор экон. наук, профессор, НИТУ «МИСИС», 119049 , г. Москва, Россия, тел.: +7 (499) 230-24-78, \\ e-mail:aarozhkov@mail.ru}

РОЖКОВ Анатолий Алексеевич

\section{МЕЛЬНИКОВА Анна Сергеевна}

Канд. экон. наук, доцент кафедры экономики труда и управления персоналом ФГБОУ ВО «Уральский государственный экономический университет», 620144, г. Екатеринбург, Россия, тел.: +7 (912) 245-09-41

Встатье приведены основные направления совершенствования организации труда на угледобывающих предприятиях, изложены методы повышения стимулирующей и мотивационной роли заработной платы.

Ключевые слова: организачия, эффективность, производительность, качество труда, заработная плата, тарифная система, конкурентоспособность

\section{ВВЕДЕНИЕ}

Современная практика показывает, что большинство угледобывающих компаний (АО «СУЭК», АО «УК «Кузбассразрезуголь», АО ХК «СДС-Уголь», ПАО «Южный Куз- басс», ОOО «Распадская угольная компания», АО «Русский Уголь» и другие) уделяют в настоящее время большое внимание выявлению резервов роста производительности и качества труда, повышению его эффективности [1]. Это способствует модернизации горного производства, широкому внедрению техники и инновационных технологий, всемерной экономии материальных и трудовых ресурсов, улучшению качества продукции, повышению ее конкурентоспособности, снижению производственных затрат, совершенствованию организации труда и заработной платы, усилению роли материальных стимулов в повышении результативности деятельности.

На угледобывающих предприятиях в современных социально-экономических условиях успешно реализуется комплекс мер, направленных на ликвидацию отставания в области производительности труда от ведущих промышленно развитых стран мира, внедряется система долгосрочных мероприятий технического и социальноэкономического развития горного производства [1]. При этом основное внимание уделяется изысканию резервов роста производительности труда, методическому, производственному и управленческому аспектам этой проблемы, поиску новых прогрессивных подходов к анализу, планированию и регулированию этого важнейшего экономического показателя.

\section{НАПРАВЛЕНИЯ СОВЕРШЕНСТВОВАНИЯ ОРГАНИЗАЦИИ ТРУДА}

При исследовании и изыскании резервов роста производительности труда основное внимание специалистами угледобывающих предприятий уделяется в настоящее время не только объемам добычи угля, но и материальным и трудовым затратам производства на единицу продукции, ее конкурентоспособности.

Практика показывает, что чрезмерное увлечение ростом объемов производства угольной продукции любой ценой приводит к снижению уровня производительности труда и повышению затрат на единицу продукции. Наибольший эффект достигается в случае, когда при управлении горным производством основное внимание уделяется не количеству, а качеству труда, позволяющему существенно улучшить социально-экономические показатели деятельности, обеспечить рост производительности труда, снижение трудоемкости работ, сокращение ручного тру- 
да, экономию материальных и трудовых затрат, улучшение качества продукции, повышение эффективности использования горного оборудования по мощности и во времени, снижение потерь рабочего времени $[2,3]$.

Так, прирост производительности труда за счет сокращения потерь рабочего времени может рассчитываться по формуле:

$$
\Delta \Pi=\frac{a_{2}}{a_{1}} 100-100,
$$

где: $\Delta$ П- прирост производительности труда, \%; $a_{1}$ и $a_{2}-$ часовой эффективный фонд рабочего времени одного работника соответственно до и после сокращения потерь.

Работа по изысканию на угледобывающих предприятиях внутрипроизводственных резервов оказывается недостаточно эффективной, если основой модернизации горного производства и рабочих процессов является внедрение новой технологии и современной горной техники без должной увязки с совершенствованием организации труда и стимулирования. При этом многие специалисты считают, что применяемая сдельная форма оплаты труда в современных условиях во многих случаях не приносит желаемой эффективности. Гораздо больший эффект можно получать от повышения творческой инициативы персонала, высокого уровня технологической, производственной и трудовой дисциплины, роста профессионального мастерства и уровня специальной подготовки работников, сокращения простоев и потерь рабочего времени на основных и вспомогательных процессах. Практика показывает, что модернизация горного производства только на основе внедрения инноваци- онной техники и технологии не во всех случаях обеспечивает должный рост производительности труда и снижение всех видов затрат, если она не базируется на совершенствовании бизнес-процессов и организации труда на рабочих местах.

Рационализация всех операций на рабочих местах основных и вспомогательных процессов может в ряде случаев обеспечить существенный рост производительности труда и снижение затрат без внедрения нового горнотранспортного оборудования. Главное, чтобы совершенствование организации производства и труда осуществлялось системно и комплексно, охватывало все аспекты деятельности персонала.

Повышение производительности, качества и эффективности труда должно осуществляться взаимосвязанно и комплексно с учетом требований максимального повышения конкурентоспособности угледобывающего производства и его экономичности. На рис. 1 приведена рекомендуемая структурная схема, характеризующая взаимосвязи показателей производительности, качества и эффективности труда.

Производительность труда определяется как показатель, характеризующий его результативность, отдачу каждой единицы ресурса труда. При этом, как правило, возникает вопрос о том, что рассматривать в качестве результата трудовой деятельности: ее продуктивность, то есть произведенное количество продукции и затраченные на это ресурсы труда или эффективность его использования, характеризующаяся соотношением экономических результатов и затрат, связанных с использованием труда.

Исследования показывают, что второй подход к пониманию сути производительности труда в большей степени соответствует рыночным отношениям, так как характеризует результаты финансовой деятельности, снижения себестоимости угольной продукции и повышения рентабельности, то есть экономичность угледобывающего производства и его конкурентоспособность [4].

В современных условиях в термин «производительность» в ряде случаев вводятся затраты в форме трудовых ресурсов, капиталы (физические и финансовые активы), энергия, материалы, информация, которая преобразуется в продукцию. В этом случае производительность трактуется как соотношение количества продукции, произведенной за определенный период времени, к совокупному количеству потребляемых ресурсов. В этом случае речь уже идет не только о производительности труда, но и о материалах, энергии, оборудовании и т.д.

Количество затраченного труда определяется нормами выработки,

Pис. 1. Схема взаимосвязи показателей производительности и эффективности труда на практике 
а качество труда - уровнем квалификации, сложности, тяжести и условиями труда. Экономическая эффективность труда - это разность между полученной экономией и затратами, связанными с внедрением определенного мероприятия, направленного на повышение результативности.

Практика показывает, что все рассмотренные экономические понятия находятся во взаимосвязи и взаимозависимости.

Уровень повышения производительности, качества и эффективности труда существенно зависит от прогрессивности организации труда на основных и вспомогательных процессах производства.

На рис. 2 приведена структурная схема, раскрывающая основные аспекты совершенствования организации труда, способствующие повышению производительности, качества и эффективности труда на угледобывающих предприятиях.

В практике угледобывающих предприятий организация труда рассматривается как целая система осуществления основных и вспомогательных трудовых процессов во взаимодействии с исполнителями и средствами труда, позволяющая наиболее эффективно достигать в конкретных условиях поставленных целей и задач горного производства. В определенных горногеологических условиях угледобывающего производства указанные цели систематизируются как:

- экономическая (рациональное использование фонда рабочего времени, рост производительности труда и снижение трудоемкости горных работ, улучшение использования горнотранспортного оборудования, обеспечение выпуска качественной продукции);

- организационная (рационализация состава и последовательности выполнения горных работ, обеспечение ритмичности и безопасности всего комплекса трудовых процессов, повышение уровня индивидуальной и коллективной ответственности, формирование действенной системы оплаты, стимулирования, мотивации и нормирования труда персонала);

- психофизиологическая (нормализация условий производства и труда, обеспечение психологической совместимости труда нереально в определенных горногеологических условиях, рационализация психологических затрат работников);

- социальная (рост привлекательности труда, обеспечение возможности квалификационного роста и повышения профессионального мастерства, создание условий для социальной защиты персонала).

В процессе совершенствования организации труда на угледобывающих предприятиях должны производиться оптимизация всех ее структурных элементов и горнотехнических параметров, обеспечение строгого соответствия их важнейшим целям и задачам угледобывающего производства, а также критериям роста производительности, качества и эффективности труда с учетом конъюнктуры рыночных отношений.

Опыт работы угледобывающих предприятий свидетельствует, что результатом совершенствования организации являются, как правило, снижение себестоимости угольной продукции и получение дополнительной прибыли за счет роста производительности труда, снижения трудоемкости работ и сокращения численности персонала, увеличения выпуска и реализации угольной продукции, уменьшения зарплатоемкости продукции и улучшения ее

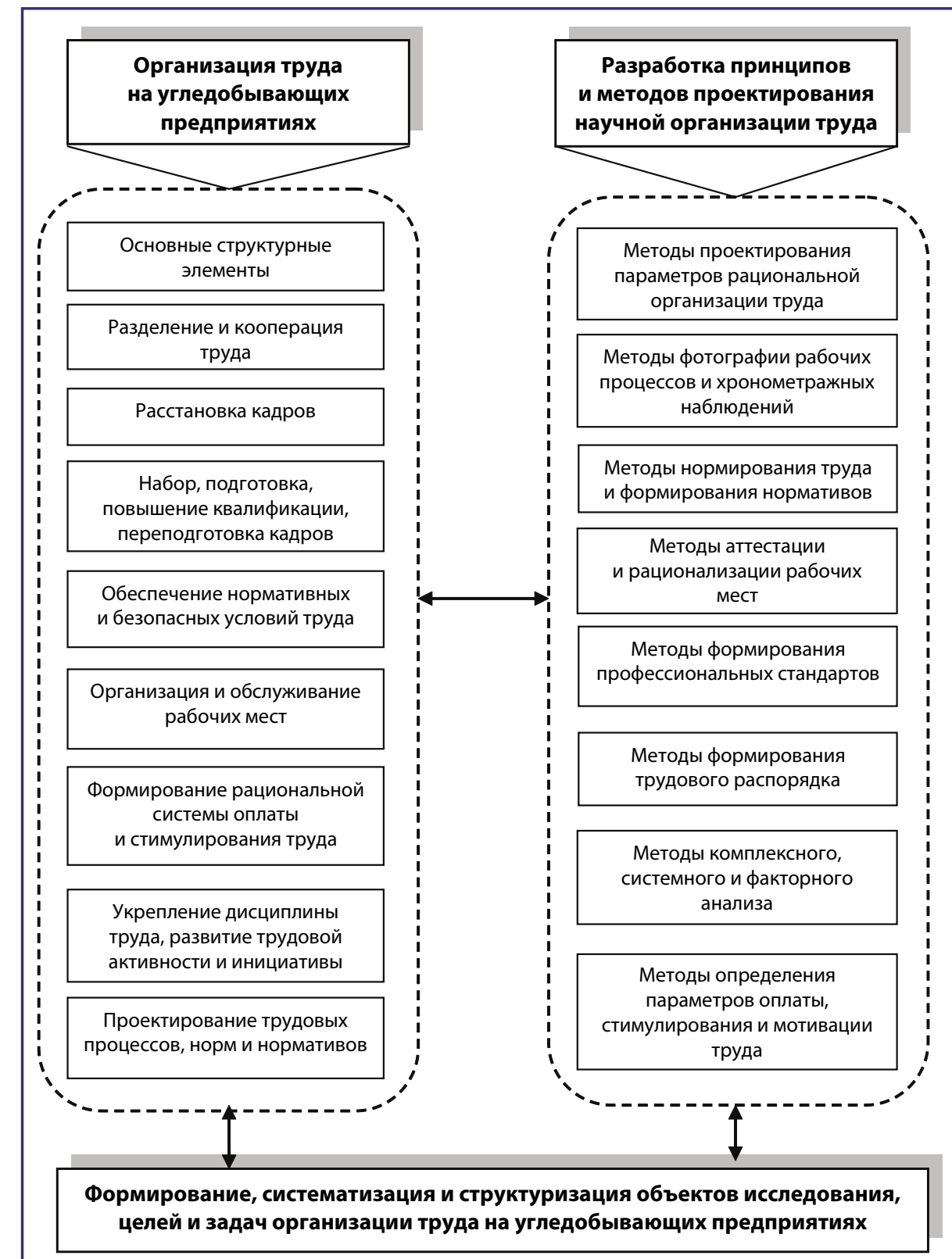

Рис. 2. Структурная схема, раскрывающая основные аспекты совершенствования организачии труда, способствующие росту его производительности, качества и эффрективности 
качества, экономии материальных и трудовых затрат. Экономическая эффективность совершенствования организации труда на угледобывающих предприятиях определяется как разность между экономией финансовых средств и всеми видами затрат, связанных с реализацией комплекса мероприятий по рационализации трудовых процессов на рабочих местах.

Например, экономию от снижения себестоимости угольной продукции за счет осуществления мероприятия по совершенствованию организации труда можно, в частности, определить по следующей формуле:

$$
\exists_{c}=\left(C_{1}-C_{2}\right) \cdot b_{2^{\prime}}
$$

где: Э - экономия от снижения себестоимости угольной продукции, руб.; $C_{1}, C_{2}$ - себестоимость единицы продукции соответственно до и после осуществления мероприятия, руб.; $b_{2}$ - выпуск угольной продукции с учетом осуществления мероприятия, т.

При совершенствовании организации труда на угледобывающих предприятиях с целью роста производительности, качества и эффективности труда важно увязывать ее в единое целое с техническими, технологическими, экономическими, социальными аспектами формирования систем применительно к конкретным горно-геологическим условиям производства. На практике особую роль играет обеспечение должной взаимосвязи и взаимо-

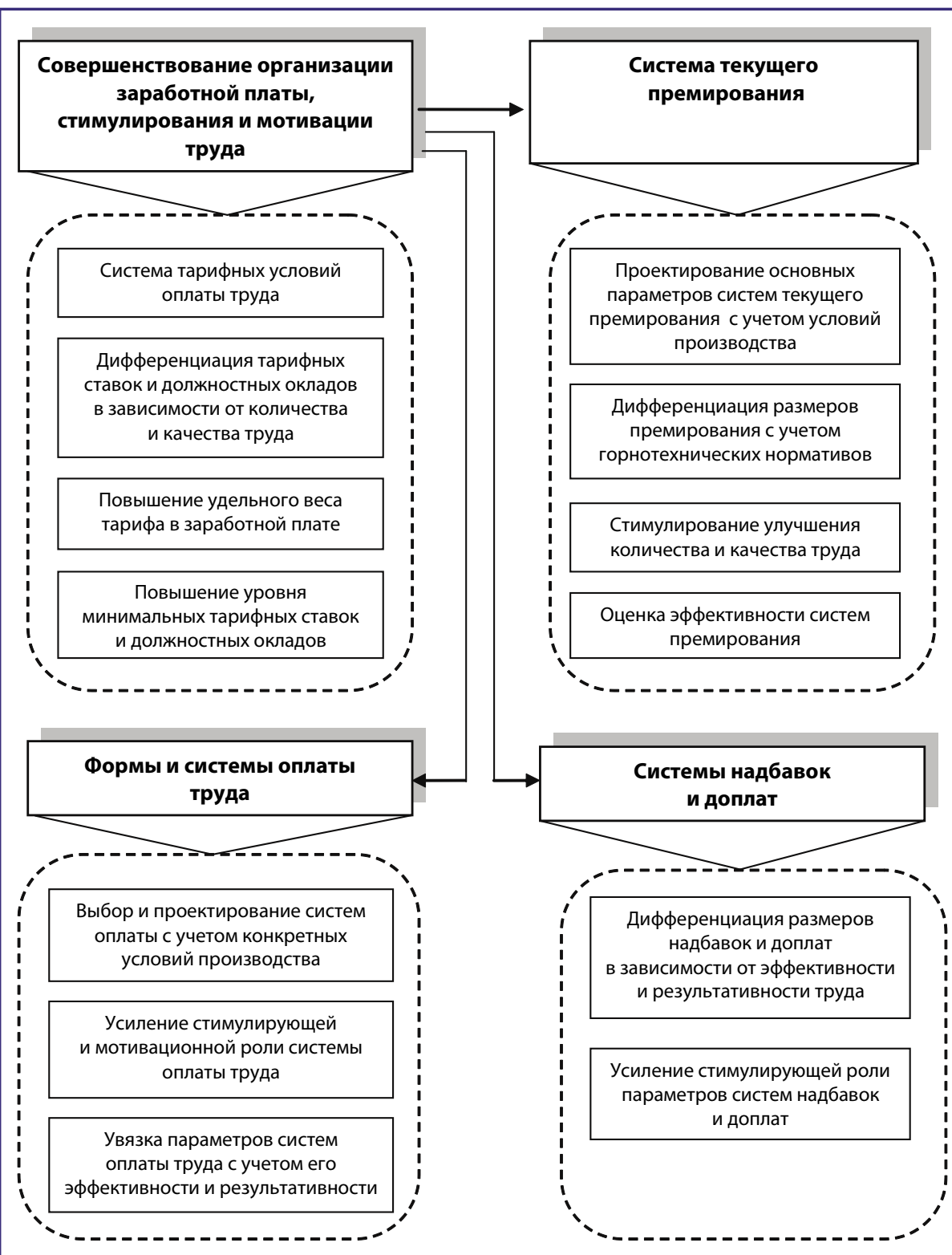

Рис. 3. Основные направления совершенствования параметров организации заработной платы на угледобывающих предприятиях

зависимости внутреннего построения любой системы организации труда с необходимыми для ее нормального функционирования внешними связями, обеспечивающими интегрированное развитие. По мнению специалистов, уровень интегрированности любой системы организации труда на угледобывающем предприятии должен рассматриваться как важнейший критерий ее эффективности и качества [5].

\section{МЕТОДЫ ПОВЫШЕНИЯ СТИМУЛИРУЮЩЕЙ РОЛИ ЗАРАБОТНОЙ ПЛАТЫ}

Одним из важнейших элементов при поиске резервов роста производительности, качества и эффективности труда на угледобывающих предприятиях является организация заработной платы персонала, позволяющая реализовать в условиях горного производства стимулирование и мотивацию к результативному труду. На рис. 3 приведена структурная схема, характеризующая основные направления совершенствования организации заработной платы.
Основную роль в организации заработной платы на угледобывающих предприятиях играют при разработке отраслевых соглашений и коллективных договоров тарифные условия оплаты труда, включающие минимальные тарифные ставки и оклады, тарифные сетки и схемы должностных окладов, тарифные коэффициенты, тарифноквалификационные и квалификационные характеристики, дифференциацию параметров тарифной системы в зависимости от квалификации работников, сложности, тяжести и условий труда.

Все применяемые методы оценки сложности труда при проектировании тарифных условий можно условно подразделить на шесть групп (см. таблицу).

При проектировании системы тарифных условий оплаты труда работников угледобывающих предприятий необходимо исходить из того, что решение всех задач должно основываться не на случайных, субъективных оценках, а на совокупности обоснованных наукой и апробированных практикой рекомендациях и методических положениях [6]. 
Методы проектирования тарифных условий оплаты труда

\begin{tabular}{|c|c|c|c|}
\hline $\begin{array}{c}\text { Группа методов } \\
\text { проектирования } \\
\text { тарифной системы }\end{array}$ & $\begin{array}{l}\text { Метод проектирования } \\
\text { параметров тарифной } \\
\text { системы на основе } \\
\text { сложности труда }\end{array}$ & $\begin{array}{l}\text { Основные модификации } \\
\text { методов оценки сложности труда }\end{array}$ & $\begin{array}{c}\text { Использование методов } \\
\text { при проектировании параметров } \\
\text { тарифной сетки }\end{array}$ \\
\hline Первая & По времени подготовки & $\begin{array}{l}\text { 1. Оценка сложности по результатам } \\
\text { учета времени общеобразовательной } \\
\text { и специальной подготовки, а также } \\
\text { времени освоения профессии. } \\
\text { 2. Оценка сложности на основе време- } \\
\text { ни общеобразовательной подготовки и } \\
\text { времени освоения профессии }\end{array}$ & $\begin{array}{l}\text { При определении тарифных коэффи- } \\
\text { циентов и числа тарифных разрядов }\end{array}$ \\
\hline Вторая & Психологический & $\begin{array}{l}\text { 1. Оценка сложности операторского } \\
\text { труда на основе потока информации. } \\
\text { 2. Оценка рабочих процессов по ми- } \\
\text { кроэлементным нормативам }\end{array}$ & $\begin{array}{l}\text { При тарификации работ и опреде- } \\
\text { лении количественных различий в } \\
\text { сложности операторского труда }\end{array}$ \\
\hline Третья & Суммарный & $\begin{array}{l}\text { 1. Простой суммарный. } \\
\text { 2. Суммарно-аналитический }\end{array}$ & $\begin{array}{l}\text { При тарификации работ и определе- } \\
\text { нии числа разрядов }\end{array}$ \\
\hline Четвертая & Аналитический & $\begin{array}{l}\text { 1. Аналитический укрупненный. } \\
\text { 2. Аналитический в технологическом } \\
\text { варианте }\end{array}$ & $\begin{array}{l}\text { При проектировании тарифных сеток } \\
\text { и тарифно-квалификационных харак- } \\
\text { теристик }\end{array}$ \\
\hline Пятая & Экспертный & $\begin{array}{l}\text { 1. Ранжирование работ. } \\
\text { 2. Инженерные оценки (анкетный } \\
\text { опрос) }\end{array}$ & $\begin{array}{l}\text { При тарификации работ (дополни- } \\
\text { тельно к аналитическому методу) }\end{array}$ \\
\hline Шестая & Экономический & По фактической заработной плате & $\begin{array}{l}\text { Для проектирования тарифных сеток } \\
\text { (при предварительном анализе) }\end{array}$ \\
\hline
\end{tabular}

Тарифные условия оплаты труда на научной основе должны находиться в тесной взаимосвязи с техническим и технологическим развитием горного производства и базироваться на современных методах, позволяющих обеспечивать наиболее целесообразные способы стимулирования роста производительности, качества и эффективности труда.

Комплексное проектирование тарифных условий оплаты труда на угледобывающих предприятиях нельзя рассматривать только как систему взаимосвязанных элементов и параметров или только как процесс приведения оплаты труда в соответствие с условиями технологического, технического, экономического и социального развития угледобывающего производства. Эту задачу необходимо решать, с одной стороны, на системной основе (рассматривать совокупность структурных элементов и параметров), стимулирующей всестороннее развитие горного производства, а с другой стороны, как динамичный и непрерывный процесс совершенствования тарифной оплаты с учетом развития техники, технологии, организации производства и труда, экономики, социальных процессов.

В числе важнейших аспектов изучения подсистем организации заработной платы на угледобывающих предприятиях и, в частности, тарифных условий оплаты труда, с учетом требований модернизации шахт, разрезов, углеобогатительных фабрик, следует особо отметить следующие: системно-целевой (выделение целей и задач функционирования системы); системно-исторический (анализ ретроспективы развития системы); системно-элементный (изучение структуры элементов системы); системно-структурный (оценка и анализ взаимосвязи элементов, параметров); системно-коммуникационный (изучение взаимодей- ствия данной системы с другими системами); системнофункциональный (оценка взаимодействия элементов системы и ее динамики); системно-интегральный (анализ перспектив развития системы).

В практике угледобывающих предприятий формы оплаты труда принято определять как методы формирования заработной платы, а системы - как методы, с помощью которых осуществляется учет в фактической заработной плате количества и качества труда. При этом текущее премирование является неизменной составной частью сдельно-премиальной и повременно-премиальной систем оплаты труда, позволяющей осуществлять эффективное стимулирование.

При проектировании систем оплаты труда на угледобывающих предприятиях в современных условиях основное внимание должно уделяться мотивации роста производительности, качества и эффективности труда, так как это является основой повышения экономичности и конкурентоспособности горного производства.

\section{ЗАКЛЮЧЕНИЕ}

В современных условиях хозяйствования повышение эффективности угледобывающего производства в значительной степени зависит от улучшения качественных показателей и, прежде всего, от изыскания резервов роста производительности труда и снижения трудоемкости работ [7].

В угледобывающих организациях накоплен значительный практический и методический опыт управления производительностью труда, особенно в области анализа, планирования, регулирования и стимулирования, который требует всемерного изучения, обобщения и распространения на предприятиях при различных способах добычи угля. 
Основным аспектом является в настоящее время реализация системного, комплексного подхода к вскрытию резервов роста производительности труда с учетом технических, технологических, организационных и социальных факторов.

На основе исследований в данной работе предпринята попытка комплексного обобщения важнейших аспектов, направлений и методов управления производительностью труда с учетом модернизации угледобывающего производства.

\section{Список литературы}

1. Уголь России (1722-2017). Юбилейное издание к 70-летию Дня шахтера и 295-летию с начала угледобычи в России. М.: Принтлето, 2017. 264 с.

2. Попов В.Н., Грибин Ю.Г., Гаркавенко А.Н. Повышение эффективности управления резервами роста производительности труда на угледобывающих предприятиях // Уголь. 2014. № 11. С. 35-38. URL: http://www.ugolinfo.ru/ Free/112014.pdf (дата обращения: 15.08.2018).

3. Как нам повысить производительность труда // Журнал «Эксперт». 2010. № 18 (703). 10-17 мая URL: http://expert. ru/expert/2010/18/ (дата обращения: 15.08.2018).
4. Попов В.Н., Грибин Ю.Г., Ефимова Г.А., Гаркавенко А.Н., Семина Л.Ю. Методические рекомендации по повышению эффективности управления материальными и трудовыми ресурсами в условиях модернизации и инновационного развития угледобывающих организаций // Уголь. 2015. № 6. С. 48-53. URL: http://www.ugolinfo.ru/ Free/062015.pdf (дата обращения: 15.08.2018).

5. Экономика труда: учебник. М.: Юрист, 2002. 558 с.

6. Основные направления совершенствования профессионального состава, тарификации и тарифноквалификационных характеристик рабочих в угольной промышленности / Ю.Г. Грибин, Г.А. Ефимова, В.Н. Попов, А.А. Рожков // Уголь. 2012. № 6. C.44-47. URL: http:// www.ugolinfo.ru/Free/062012.pdf (дата обращения: 15.08.2018).

7. Грибин Ю.Г., Попов В.Н., Рожков А.А. Системный подход к выявлению внутрипроизводственных резервов повышения эффективности социально-экономического управления горным предприятием // Уголь. 2017. № 4. C.36-41. URL: http://www.ugolinfo.ru/Free/042017.pdf (дата обращения: 15.08.2018).

UDC 65.01:331.87:658.15 @ V.N. Popov, Yu.G. Gribin, A.N. Garkavenko, A.A. Rozhkov, A.S. Melnikova, 2018

ECONOMIC OF MINING

ISSN 0041-5790 (Print) • ISSN 2412-8333 (Online) • Ugol' - Russian Coal Journal, 2018, № 10, pp. 60-65

\section{Title \\ IMPROVEMENT OF LABOR EFFICIENCY, QUALITY AND PERFORMANCE IS THE BASIC PRINCIPLE OF COAL MINING ENTERPRISES COST EFFICIENCY AND COMPETITIVENESS}

DOI: http://dx.doi.org/10.18796/0041-5790-2018-10-60-65

\section{Authors}

Popov V.N. ${ }^{1}$, Gribin Yu.G. ${ }^{1}$, Garkavenko A.N. ${ }^{2}$, Rozhkov A.A. ${ }^{3}$, Melnikova A.S. ${ }^{4}$

${ }^{1}$ Moscow, 119049, Russian Federation

2 "Geopolis" JSC, Moscow, 119017, Russian Federation

${ }^{3}$ National University of Science and Technology "MISIS" (NUST "MISIS"), Moscow, 119049, Russian Federation

${ }^{4}$ Ural State University of Economics, Yekaterinburg, 620144, Russian Federation

\section{Authors' Information}

Popov V.N., Doctor of Economic Sciences, Professor, tel.: +7 (916) 953-50-74, e-mail: 220145@mail.ru

Gribin Yu.G., Doctor of Economic Sciences, Professor, tel.: +7 (910) 471-42-08, e-mail: ephimovaga@mail.ru Garkavenko A.N., Doctor of Economic Sciences, tel.: +7 (495) 223-33-63, e-mail: info@geopolis.ru Rozhkov A.A., Doctor of Economic Sciences, Professor, tel.: +7 (499) 230-24-78, e-mail: aarozhkov@mail.ru

Melnikova A.S., PhD (Economic), Associate Professor of Labour Economics and Personal Management Department, tel.: +7 (912) 245-09-41

\section{Abstract}

The paper addresses the major trends of coal mining enterprises labor organization improvement, presents the methods of salary stimulating and motivation role enhancement.

\section{Keywords}

Organization, Performance, Efficiency, Labor quality, Salary, Tariff system, Competitiveness

\section{References}

1. Ugol Rossii (1722-2017) [Coal of Russia (1722 - 2017)]. Anniversary issue to the 70th anniversary of the Miner's Day and the 295-th anniversary of coal mining in Russia. Moscow, Printleto Publ., 2017, 264 p.

2. Popov V.N., Gribin Yu.G. \& Garkavenko A.N. Povyshenie effektivnosti upravleniya rezervami rosta proizvoditel'nosti truda na ugledobyvayushchikh predpriyatiyakh [Increasing Management Efficiency of the Labor Productivity Growth Reserves at Coal Mines]. Ugol' - Russian Coal Journal, 2014, No. 11 pp. 35-38. Available at: http://www.ugolinfo.ru/Free/112014.pdf (accessed 15.08.2018).

3. Kak nam povysit proizvoditelnost truda [How can we improve labor efficiency]. Ekspert - Expert, 2010, No. 18(703), 10-17 May. Available at: http:// expert.ru/expert/2010/18/ (accessed 15.08.2018).

4. Popov V.N., Gribin Yu.G., Efimova G.A., Garkavenko A.N. \& Semina L.Yu Metodicheskie rekomendatsii po povysheniyu effektivnosti upravleniya material'nymi i trudovymi resursami v usloviyakh modernizatsii i innovatsionnogo razvitiya ugledobyvayushchikh organizatsii [Methodological Recommendations for Management Effectiveness Improvement of Material and Human Resources in the Modernization and Innovative Development of Coal-Mining Companies]. Ugol' - Russian Coal Journal, 2015, No. 6, pp. 48-53. Available at: http://www.ugolinfo.ru/Free/062015.pdf (accessed 15.08.2018).

5. Ekonomika truda: Uchebnik [Work economy: Textbook]. Moscow, Lawyer Publ., 2002, 558 p.

6. Popov V.N., Gribin Yu.G., Rozhkov A.A. \& Efimova G.A. Osnovnye napravleniya sovershenstvovaniya professional'nogo sostava, tarifikatsii i tarifnokvalifikatsionnykh kharakteristik rabochikh v ugol'noi promyshlennosti [Main Areas of Improving Occupational Pattern and Coal Industry Worker Wage Rate Characteristics Tariffication]. Ugol'- Russian Coal Journal, 2012, No. 6, pp.44-47. Available at: http://www.ugolinfo.ru/Free/062012.pdf (accessed 15.08.2018). 7. Gribin Yu.G., Popov V.N. \& Rozhkov A.A. Sistemnyi podkhod k vyyavleniyu vnutriproizvodstvennykh rezervov povysheniya effektivnosti sotsial'no-ekonomicheskogo upravleniya gornym predpriyatiem [Integrated approach to identification of in-process reserves for mining enterprise social and economic management efficiency improvement]. Ugol' - Russian Coal Journal 2017, No. 4, pp. 36-41. Available at: http://www.ugolinfo.ru/Free/042017.pdf (accessed 15.08.2018). 


\section{Актуальность повышения уровня энергоэффективности и безопасности выемочного участка угольной шахты}

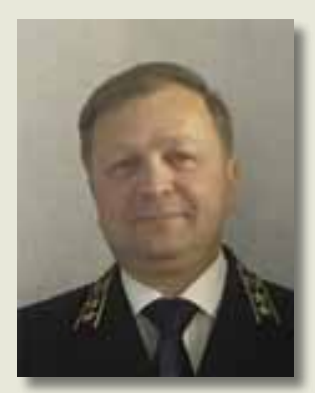

\section{копылов}

\section{Константин Николаевич}

Технический директор

$A O$ «СУЭК»,

115054, г. Москва, Россия

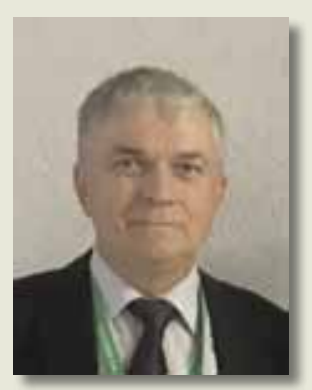

\section{КУБРИН Сергей Сергеевич}

Доктор техн. наук, профессор, заведующий лабораторией 2.3 «Геотехнологических рисков при освоении газоносных угольных и рудных месторождений» ИПКОН РАН, 111020 , г. Москва, Россия

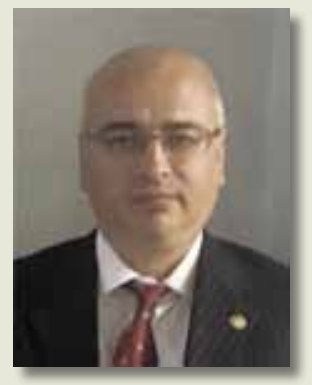

РЕШЕТНЯК Сергей Николаевич

Канд. техн. наук, дочент кафедры «Энергетика

и энергоэффрективность горной промышленности» НИТУ «МИСИС», старший научный сотрудник лаборатории

2.3 «Геотехнологических рисков при освоении газоносных угольных и рудных месторождений» ИПКОН РАН, 119049, г. Москва, Россия, тел.: +7 (495) 360-76-05, e-mail: reshetniak@inbox.ru ставленной статье рассмотрены актуальные аспекты разработки технологии выемки угля при минимальном количестве обслуживающего персонала в условиях подземных горных работ на примере предприятий АО «СУЭК». Функционирование представленной структуры возможно при условии модернизации систем электроприводов основного оборудования путем перевода из нерегулируемого режима в регулируемый. Следует отметить, что представленная структура позволит значительно повысить уровень промышленной безопасности на шахтах, опасных по внезапным выбросам газа и пыли.

Ключевые слова: вызовы для предприятий угольной промышленности, энергоэффективные и безопасные технологии, безлюдная выемка угля, инновационная структурная схема управления очистным участком угольной шахты, метановыделение, пылеобразование.

\section{ВВЕДЕНИЕ}

Мировая конъюнктура рынка углеводородов создает предпосылки для повышения конкурентоспособности добычи угля подземным способом. Это может быть достигнуто путем снижения себестоимости добычи полезного ископаемого, применением современных технологий, а также применением энергоэффективного оборудования. Основными вызовами для предприятий угольной промышленности, по заявлению министра энергетики Российской Федерации А.В. Новака, являются [1]:

- риски сокращения внутреннего и внешнего угольных рынков;

- постоянный рост транспортной составляющей в цене угольной продукции для потребителей;

- убыточность большого числа угольных компаний;

- рост фискальной нагрузки на угольную промышленность при недропользовании;

- наличие большого количества шахт, работающих в сложных горно-геологических условиях, что обусловливает высокие риски возникновения крупных аварий с человеческими жертвами;

- недостаточный уровень бюджетного финансирования мероприятий для завершения реструктуризации угольной промышленности и выполнения «Комплексной программы поэтапной ликвидации убыточных шахт».

На совещании заместителя председателя Правительства Российской Федерации А.В. Дворковича (протокол № АД-П9-39пр от 16.03.2016) рассматривался вопрос о по- 


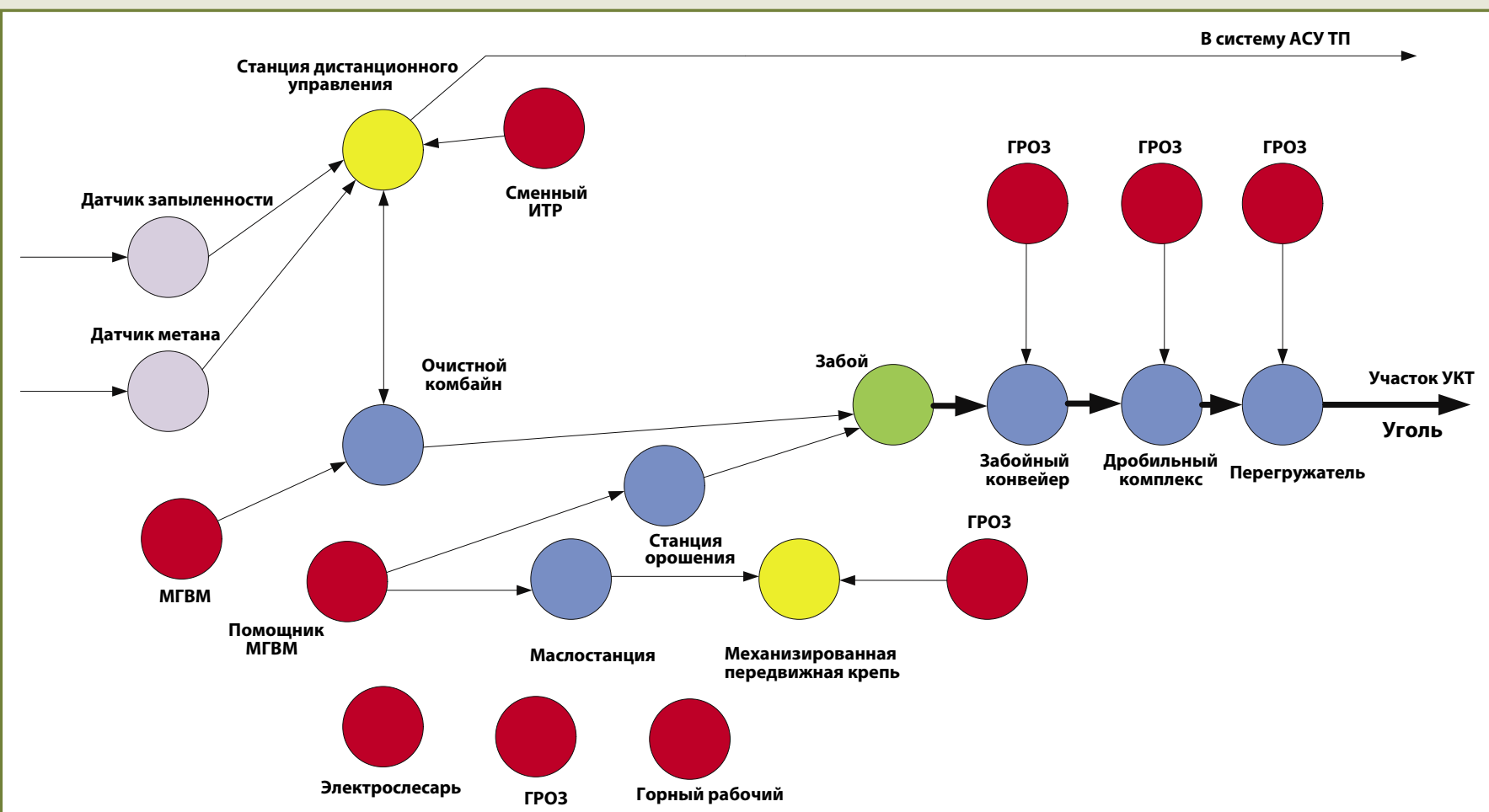

Очистной участок угольной шахты

Рис. 1. Существующая структура управления выемочного участка угольной шахты

вышении уровня промышленной безопасности на угольных шахтах и эффективности отработки запасов. Все это позволяет сделать заключение об актуальности задачи модернизации предприятий по добыче угля подземным способом за счет современных, энергоэффективных и безопасных технологий.

\section{ЭНЕРГОЭФФЕКТИВНОСТЬ И БЕЗОПАСНОСТЬ ВЫЕМОЧНОГО УЧАСТКА УГОЛЬНОЙ ШАХТЫ}

Одним из направлений развития предприятий по добыче угля подземным способом является снижение количества персонала в выемочном забое. Этот способ добычи предусматривает вывод персонала из выемочного забоя (кроме выполнения вспомогательных работ монтажа, демонтажа и ремонта оборудования). Все управление оборудованием, расположенным на выемочном участке, производится из вентиляционного штрека с использованием станции дистанционного управления (штрековая станция).

К основному оборудованию выемочного участка относятся: выемочный комбайн; механизированная передвижная крепь; забойный конвейер; дробильный комплекс; станция орошения. В настоящее время управление выемочным комбайном производится непосредственно из выемочного забоя (в лучшем случае, управление выемочным комбайном производится от штрековой станции управления, однако такие способы управления - единичны) [2]. Регулирование режимов работы выемочным комбайном осуществляется в неполном объеме, производится только регулировка органов подачи, органы резания работают с постоянной скоростью резанья угля [3]. Контроль за газо- и пылевыделением в выемочном забое осуществляется с помощью датчиков метана и запыленности, контроль которых производится непосредственно в забое персоналом участка.
Существующая структура управления выемочного участка угольной шахты представлена на рис. 1 .

В состав смены выемочного участка угольной шахты, как правило, входят: звено горнорабочих выемочного забоя (ГРОЗ) - не менее пяти человек; машинист горновыемочных машин (МГВМ) - не менее двух человек (один из которых помощник МГВМ); подземный электрослесарь - не менее двух человек; горный рабочий - не менее двух человек; сменный инженерно-технический работник (ИТР) - один человек. Следует отметить, что количество персонала выемочного участка в значительной степени различается, это обусловлено специфическими горно-геологическими условиями и способами разработки конкретного предприятия. Основной персонал выемочного забоя - это ГРОЗ, которые производят зачистку поверхности перед передвижкой секции крепи, передвигают механизированную крепь, контролируют работу забойного конвейера, дробильного комплекса, перегружателя.

Машинист горновыемочных машин производит управление очистным механизированным комплексом, его помощник производит управление маслостанциями и станциями орошения. Подземный электрослесарь производит контроль и ремонт оборудования, расположенного на участке. В состав смены также входят подземные горнорабочие, основными функциями которых является доставка необходимых материалов на участок, расштыбовка конвейеров. Также в состав персонала участка входит сменный ИТР, который производит контроль и управление выемочным участком. Отметим, что выемочный участок угольной шахты является наиболее опасным по внезапным выбросам газа и пыли, авария на нем приводит к многочисленным жертвам. В связи с этим на участке следует уделить особое внимание безопасности обслуживающего персонала. Количество рабочих в выемочном за- 
Количество рабочих в выемочном забое угольных шахт

\begin{tabular}{|l|c|c|c|}
\multicolumn{1}{c|}{ Шахта } & $\begin{array}{c}\text { Ремонтная смена, } \\
\text { чел./ ГРО3 }\end{array}$ & $\begin{array}{c}\text { Рабочая смена, } \\
\text { чел./ Гро3 }\end{array}$ & $\begin{array}{c}\text { Количество рабочих } \\
\text { в сутки, чел./ Гр03 }\end{array}$ \\
\hline «Красноярская» & $32 / 11$ & $10 / 6$ & $63 / 29$ \\
\hline «Полысаевская» & $30 / 13$ & $12 / 7$ & $66 / 34$ \\
\hline «Талдинская-Западная-2» & $25 / 10$ & $12 / 5$ & $62 / 25$ \\
\hline «Котинская» & $21 / 12$ & $9 / 6$ & $48 / 30$ \\
\hline «Комсомолец» & $23 / 15$ & $10 / 7$ & $53 / 36$ \\
\hline «Талдинская-Западная-1» & $29 / 20$ & $11 / 8$ & $62 / 44$ \\
\hline
\end{tabular}

бое ряда угольных шахт АО «СУЭК-Кузбасс» представлено в таблице.

Анализ сведений, представленных в табличе, показывает, что более $50 \%$ персонала выемочного участка составляют ГРОЗы (именно эти рабочие являются наиболее частыми жертвами аварий на угольных шахтах).

В качестве решения задачи модернизации предприятий по добыче угля подземным способом за счет современных, энергоэффективных и безопасных технологий предлагается инновационная структурная схема управления выемочным участком угольной шахты, которая значительно уменьшит количество обслуживающего персонала (рис. 2).

На схеме представлено взаимодействие основного оборудования выемочного забоя с датчиками, отслеживающими параметры безопасного и энергоэффективного режима работы. Основным энергоресурсом в подземных горных условиях является электрическая энергия, (процент потребления которой достигает $80 \%$ ), поэтому данному энергетическому ресурсу следует уделить особое внимание $[4,5,6]$. Для оценки режимов работы электрооборудования необходимо создание автоматизированной информационно-измерительной системы технического учета электрической энергии. Это позволит получить достоверные показания режимов работы электрооборудова- ния, расположенного в условиях подземных горных выработок, всему заинтересованному персоналу для оперативного реагирования на изменения режимов работы $[7,8,9]$.

В настоящее время анализ режимов работы электрооборудования, расположенного в подземных горных выработках, производится на основе электрического баланса потребителей участковой понизительной подстанции [10]. Ведутся работы по анализу электропотребления в условиях работы горнодобывающего предприятия, в частности на алмазодобывающих предприятиях Российской Федерации, однако дальше лабораторных исследований, без специфики подземных работ, данные научные изыскания не продвинулись [11]. Функционирование представленной структуры (см. рис. 2) возможно при условии модернизации систем электроприводов основного оборудования, расположенного на выемочном участке, путем перевода из нерегулируемого режима работы в регулируемый режим. В системах управления электроприводами оборудования выемочного участка, как правило, используются асинхронные двигатели с короткозамкнутым ротором и прямым пуском. В этом случае регулирование скорости вращения исполнительных органов не осуществляется. В качестве модернизированной системы электропривода основного оборудования предлагается система «преобразователь частоты -

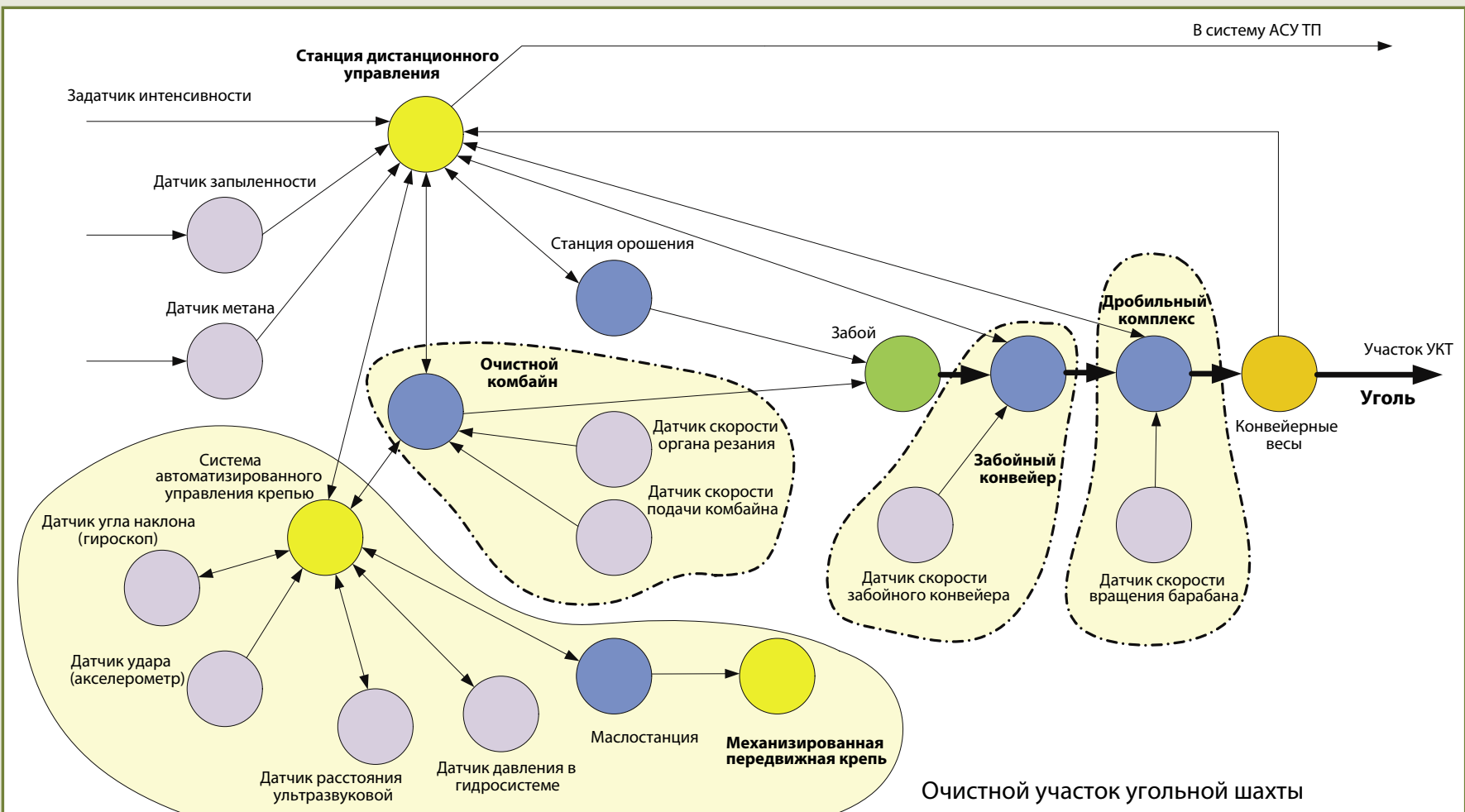

Puс. 2. Структура инновационного управления выемочного участка угольной шахты 
асинхронный двигатель с короткозамкнутым ротором». Эта система электроприводов достаточно хорошо зарекомендовала себя в условиях подземных горных работ, имеется вариант взрывозащищенного исполнения. Необходима модернизация системы электроприводов механизма органов резания выемочного комбайна, маслостанции, станции орошения, забойного конвейера, дробильного комплекса. Результатом этого являются значительное увеличение ресурса основного оборудования за счет «плавного пуска» (снижение рывков при пуске), снижение электропотребления за счет энергоэффективных режимов работы, что скажется на себестоимости добычи угля.

Немаловажным фактором, влияющим на производительность выемочного участка, является процесс выделения метана при добыче угля, так как угольные месторождения России - самые метаноносные (в 1 т угля содержится в среднем 8,3 кг метана, среднемировой показатель - 4,9 кг метана на 1 т угля) $[12,13]$. Основными источниками метановыделения в призабойном пространстве лавы являются: поверхность забоя, вмещающие породы, погашенное пространство, отбитый уголь. Кроме того, интенсивность метановыделения возрастает в среднем в 2-3 раза по сравнению с фоновым выделением при работе выемочного комбайна $[14,15]$. Установлено, что значительное влияние на метановыделение и пылеобразование в процессе добычи полезного ископаемого оказывает величина фракций. Чем больше фракция, тем меньше метановыделение [16, 17], поэтому необходимо связать с помощью обратных связей датчики метановыделения и запыленности со скоростью вращения шнека и скоростью подачи выемочного комбайна. Возможность отслеживать метановыделение и пылеобразование в забое, а также автоматическое изменение режимов работы выемочного комплекса угольной шахты позволят исключить «человеческий фактор» из процесса принятия решения по обеспечению безопасной выемки угля из забоя.

Следует отметить, что инновационная структура управления выемочным участком построена с использованием достаточно дорогостоящего и высокотехнологичного оборудования, обслуживать которое должны высококвалифицированные специалисты. Поэтому обучению специалистов, работающих на высокотехнологичном оборудовании и уже имеющих достаточно высокий общеобразовательный уровень, необходимо уделять достаточно большое внимание с целью расширения их компетенций.

\section{ЗАКЛЮЧЕНИЕ}

Современная мировая конъюнктура рынка угля позволяет сделать заключение о необходимости модернизации оборудования предприятий по добыче угля подземным способом, опасных по внезапным выбросам газа и пыли, за счет современных, энергоэффективных и безопасных технологий с целью снижения себестоимости добычи и повышения конкурентоспособности продукции.

Сравнительный анализ существующей и инновационной структуры управления выемочным участком угольной шахты позволяет увеличить безопасность ведения горных работ путем снижения количества персонала выемочного участка и вывода оставшегося в безопасную зону (вентиляционный штрек) за счет построения единой автоматизированной системы управления функцией метано- выделения. Данный аспект позволит значительно уменьшить влияние «человеческого фактора» на процесс выемки угля, что позволит повысить безопасность ведения горных работ.

\section{Список литературы}

1. Итоги работы Минэнерго ТЭК в 2015 г. Задачи на среднесрочную перспективу / Доклад министра энергетики Российской Федерации А.В. Новака на заседании Коллегии Минэнерго России. [Электронный ресурс]. URL: http:// minenergo.gov.ru/node/4912 (дата обращения: 15.09.2018).

2. Блак Т. Автоматизация EICKOFF гарантирует безопасность и качество - в России ввели в эксплуатацию первую лаву, работающую в автоматическом режиме //Уголь. 2015. № 10. C 22-23. URL: http://www.ugolinfo.ru/Free/102015.pdf (дата обращения: 15.09.2018).

3. Очистные комбайны / С.В. Ясученя, К.Н. Копылов, В.Б. Артемьев и др. М.: Издательство «Горное дело»ООО «Киммерийский центр», 2014. 576 с.

4. Кубрин С.С., Решетняк С.Н. Автоматизированная информационно-измерительная система технического учета электроэнергии для подземных горных работ // Горный журнал. 2016. № 1. С. 87-90.

5. Решетняк С.Н. К вопросу повышения энергетических показателей промышленных предприятий // Приволжский научный вестник. 2013. № 10. С. 41-44.

6. Fashilenko V.N., Reshetnyak S.N. Improving the energy performance of industrial enterprises. Miner's week-2015 / Reports of the XXIII International scientific symposium. 2015. Pp. 570-573.

7. Kubrin S.S. Monitoring of Coal and Rock Mass Conditions, Coal Mine Air and Extraction Equipment State / Proceedings of the 8th International Conference on Physical Problems of Rock Destruction. Metallurgical Industry Press. China. 2014. Pp. 454-460.

8. Lyakhomskii A.V., Perfil'eva E.N., Petrochenkov A.B. Conceptual design and engineering strategies to increase energy efficiency at enterprises // Russian Electrical Engineering. 2015. Vol. 86. N 6. Pp. 305-308.

9. Petrochenkov A.B. An information of industrial electrotechnical complexes // Russian Electrical Engineering. 2015. Vol. 86. N 6. Pp. 692-696.

10. Ляхомский А.В., Фащиленко В.Н. Теория и практика проведения энергетических обследований предприятий минерально-сырьевого комплекса // Горный информационно-аналитический бюллетень. 2011. № 1. С. 525-529.

11. Semenov A.S., Kuznetsov N.M. An analysis of the results of monitoring the quality of electric power in an underground mine // Measurement Techniques. 2014. Pp. 343-347.

12. Trubetskoy K.N., Ruban A.D., Zaburdyaev V.S. Justification methodology of gas removal methods and their parameters in undegraund coal mines // Journal of Mining Science. 2011. Vol. 47. N 1. Pp. 1-9.

13. Parameters of dust gas could spread resulting from a caving in explosion / K.N.Trubetskoy, S.D.Victorov, V.M. Zakalinsky, A.N. Kochanov, M.B. Etkin / Rock Fragmentation by Blasting, FRAGBLAST 10. Proceedings of the 10th International Symposium on Rock Fragmentation by Blasting 2013. Pp. 529-532.

14. Проблемы обеспечения высокой производительности очистных забоев в метанообильных шахтах / А.Д. Ру- 
бан, В.Б. Артемьев, В.С. Забурдяев и др. М.: Издательство ООО «Московский издательский дом», 2009. 396 с.

15. The coalbed methane production potential method for optimization of wells location selection / Feng-Ke Dou, YongShang Kang, Shao-Feng Qin, De-Lei Mao, Jun Han // Journal of Coal Science and Engineering (China). June 2013. Vol. 19. N 2. Pp. 210-218.
16. Yazdani-Chamzini Abdolreza, Haji Yakhchali Siamak. A new model to predict roadheader performance using rock mass properties // Journal of Coal Science and Engineering (China). March 2013. Vol. 19. N 1. Pp. 51-56.

17. Захаров В.Н., Кубрин С.С., Забурдяев В.С. Комплексирование технологических стадий и операций в единый технологический процесс на основе информационных технологий // Горный информационно-аналитический бюллетень. 2015. № 6. С. 199-206.

UDC 658.5:622.272:621.31 @ K.N. Kopylov, S.S. Kubrin, S.N. Reshetnyak, 2018

PRODUCTION SETUP

ISSN 0041-5790 (Print) • ISSN 2412-8333 (Online) • Ugol' - Russian Coal Journal, 2018, № 10, Pp. 66-70

Title

THE IMPORTANCE OF IMPROVING ENERGY EFFICIENCY AND SAFETY OF COAL MINE EXTRACTION AREA

DOI: http://dx.doi.org/10.18796/0041-5790-2018-10-66-70

\section{Authors}

Kopylov K.N. ${ }^{1}$, Kubrin S.S. ${ }^{2}$, Reshetnyak S.N. ${ }^{2,3}$

1 "SUEK" JSC, Moscow, 115054, Russian Federation

${ }^{2}$ IPKON RAS, Moscow, 111020, Russian Federation

${ }^{3}$ National University of Science and Technology "MISIS" (NUST "MISIS"), Moscow, 119049, Russian Federation

\section{Authors' Information}

Kopylov K.N., Technical Director

Kubrin S.S., Doctor of Engineering Sciences, Professor, Head of laboratory

Reshetnyak S.N., PhD (Engineering), Associate Professor "Energy and Energy efficiency mining industry" Department, Senior Researcher of laboratory, tel.: +7 (495) 360-76-05, e-mail: reshetniak@inbox.ru

\section{Abstract}

Currently, the coal industry of Russia working in very difficult conditions world conditions. This significantly affects the profitability of enterprises and provides the preconditions for applying modern techniques of extraction of coal to reduce its cost. The paper presents relevant aspects in the development of technology for excavation of coal with a minimum number of staff, in terms of underground mining on the example of "SUEK" JSC. The operation of the presented structure is possible under condition of modernization of electric drives of main equipment through transfer from unregulated to regulated mode. It should be noted that the structure will significantly improve the level of industrial safety in the mines dangerous on sudden emissions of gas and dust.

\section{Keywords}

Challenges for the enterprises of coal industry, Energy efficient and safe technologies, Deserted excavation of coal, Innovative structural management scheme treatment plant site coal mine, Methane release, Dusting.

\section{References}

1. Itogi raboty Minenergo TEKv 2015 g. Zadachina srednesrochnuyu perspektivu [The results of the work of the Ministry of Energy of the Fuel and Energy Complex in 2015. Medium-term goals]. Report of the Minister of Energy of the Russian Federation A.V. Novak at the Ministry of Energy of Russia Board Meeting [Web-site]. Available at: http://minenergo.gov.ru/node/4912 (accessed 15.09.2018).

2. Blak T. Avtomatizatsiya EICKOFF garantiruet bezopasnost' i kachestvo v Rossii vveli v ekspluatatsiyu pervuyu lavu, rabotayushchuyu v avtomaticheskom rezhime [Eickhoff automation ensures higher safety and quality first automated face in Russia started operation]. Ugol' - Russian Coal Journal, 2015, No. 10, Pp. 22-23. Available at: http://www.ugolinfo.ru/Free/102015. pdf (accessed 15.09.2018).

3. Yasuchenya S.V., Kopylov K.N., Artemiev V.B. et al. Ochistnye kombayny [Shearer-loaders]. Moscow, Gornoe delo Kimmeriyskiy tsentr LLC, 2014, 576 p. 4. Kubrin S.S., Reshetnyak S.N. Avtomatizirovannaya informacionno-izmeritelnaya sistema tekhnicheskogo ucheta ehlektroehnergii dlya podzemnykh gornykh rabot [Automated information and measuring system for the technical accounting of electricity for underground mining]. Gornyy Zhurnal - Mining Journal, 2016, No. 1, Pp. 87-90.

5. Reshetnyak S.N. K voprosu povysheniya energeticheskikh pokazateley promyshlennykh predpriyatiy [To the issue of improving the energy performance of industrial enterprises]. Privolzhskiy Nauchnyy Vestnik - Privolzhsky Scientific Bulletin, 2013, No. 10, Pp. 41-44.

6. Fashilenko V.N. \& Reshetnyak S.N. Improving the energy performance of industrial enterprises. Miner's week-2015. Reports of the XXIII International scientific symposium, 2015, Pp. 570-573.

7. Kubrin S.S. Monitoring of Coal and Rock Mass Conditions, Coal Mine Air and Extraction Equipment State. Proceedings of the 8th International Conference on Physical Problems of Rock Destruction. Metallurgical Industry Press. China, 2014, Pp. 454-460.

8. Lyakhomskiy A.V., Perfil'eva E.N. \& Petrochenkov A.B. Conceptual design and engineering strategies to increase energy efficiency at enterprises. Russian Electrical Engineering, 2015, Vol. 86, No. 6, Pp. 305-308.

9. Petrochenkov A.B. An information of industrial electrotechnical complexes. Russian Electrical Engineering, 2015, Vol. 86, No. 6, Pp. 692-696.

10. Lyakhomskiy A.V. \& Fashchilenko V.N. Teoriya i praktika provedeniya energeticheskikh obsledovaniy predpriyatiy mineralno-syrevogo kompleksa [Theory and practice of conducting energy surveys of enterprises of the mineral and raw complex]. Gornyy Informacionno-Analiticheskiy Byulleten Mining Information-Analytical Bulletin, 2011, No. 1, Pp. 525-529.

11. Semenov A.S. \& Kuznetsov N.M. An analysis of the results of monitoring the quality of electric power in an underground mine. Measurement Techniques, 2014, Pp. 343-347.

12. Trubetskoy K.N., Ruban A.D. \& Zaburdyaev V.S. Justification methodology of gas removal methods and their parameters in undegraund coal mines. Journal of Mining Science, 2011, Vol. 47, No. 1, Pp. 1-9.

13. Trubetskoy K.N., Victorov S.D., Zakalinsky V.M., Kochanov A.N. \& Etkin M.B. Parameters of dust gas could spread resulting from a caving in explosion. Rock Fragmentation by Blasting, FRAGBLAST 10. Proceedings of the 10th International Symposium on Rock Fragmentation by Blasting 2013, Pp. 529-532. 14. Ruban A.D., Artemiev V.B., Zaburdyaev V.S. et al. Problemy obespecheniya vysokoy proizvoditelnosti ochistnykh zaboev $v$ metanoobilnykh shakhtakh [Problems of ensuring high productivity of coal faces in methane-rich mines]. Moscow, Moskovskij izdatelskij dom Publ., 2009, 396 p.

15. Feng-Ke Dou, Yong-Shang Kang, Shao-Feng Qin, De-Lei Mao \& Jun Han The coalbed methane production potential method for optimization of wells location selection. Journal of Coal Science and Engineering (China), June 2013, Vol. 19, No. 2, Pp. 210-218.

16. Yazdani-Chamzini Abdolreza, Haji Yakhchali Siamak. A new model to predict roadheader performance using rock mass properties. Journal of Coal Science and Engineering (China), March 2013, Vol. 19, No. 1, Pp. 51-56.

17. Zaharov V.N., Kubrin S.S. \& Zaburdyaev V.S. Kompleksirovanie tekhnologicheskikh stadiy i operatsiy $v$ edinyy tekhnologicheskiy protsess na osnove informatsionnykh tekhnologiy [Integration of manufacturing process stages and operations into a single IT-based technological flow]. Gornyy Informacionno-Analiticheskiy Byulleten - Mining Information-Analytical Bulletin, 2015, No. 6, Pp. 199-206. 


\section{При поддержке АО «ММТП» в мурманской гимназии № 8}

\section{открылся второй «портовскоЙ» класс}

При поддержке АО «Мурманский морской торговый порт» (AO «MМТП») в мурманской гимназии № 8 открылся еще один «портовской» класс.

Таким образом, стартовавший год назад по инициативе АО «ММТП» проект обучения старшеклассников в профильном транспортно-логистическом классе вышел на новый уровень, и с 1 сентября 2018 г. в гимназии № 8 г. Мурманска будут действовать уже два специализированных логистических класса:десятиклассники прошлого года перешли в одиннадцатый класс, а в 10-й класс пришли те, кто проявил интерес к портовскому делу и прошел соответствующий отбор. Конкурс при поступлении составил два человека на место, средний проходной бал $-4,7$, у десяти ребят были отличные аттестаты.

«Высокий конкурс для поступления в профильный логистический классговорит обуспехе нашей инициативы. Те, кто поступили в него, добились этой возможности своим трудом, амы создали им необходимые условия», - сказал генеральный директор АО «ММТП» Александр Масько.

В период подготовки к новому учебному году с помощью Мурманского морского торгового порта был выполнен ремонт центрального коридора гимназии и библиотеки. Ранее был отремонтирован кабинет, в котором учатся дети из профильного класса. Также для учащихся 1, 10 и 11 классов были напечатаны специальные дневники.
«Tо, что дети уже в 10-м классе могут определиться с выбором профессии, попробовать, понять, что это такое, стоит ли дальше идти по этому пути - это очень важно», - подчеркнул глава муниципального образования г. Мурманск Дмиmpий Филиппов.

Помимо основных предметов, учащиеся транспортнологистического класса будут изучать логистику, менеджмент, профессиональный английский язык. Также старшеклассников ждет знакомство с производством, историей и социальными проектами $\mathrm{AO}$ «Мурманский морской торговый порт».

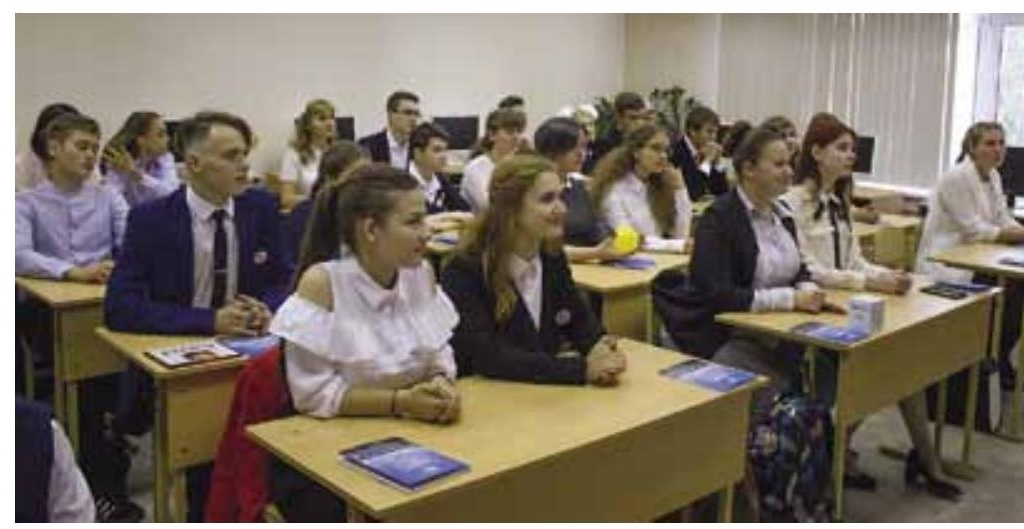

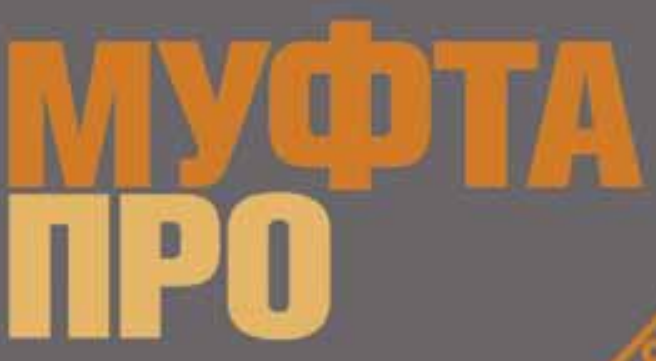

\section{Мы предлагаем:}

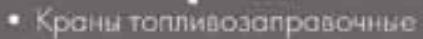

- 3anpasorнie xлianaны

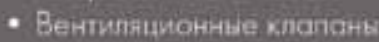

- Cnctema FIS PITBOSS Ana 3anpaвk kopbepной техники

- Cuctema yuera ronnhad SAMPIS.p.A.

- Cralnohaphbe, no6иn bree и анотоппивозаправщики co ckopoctio no 1500 n/muiryty

\section{Контакты:}

OOO - MVФTA $T$ PO,

ten $+7(499) 3946060$

e-mail: muftapro@gmail com

waw multaprosu/

mun.muftapro,com
FAST FILL SYSTEMS
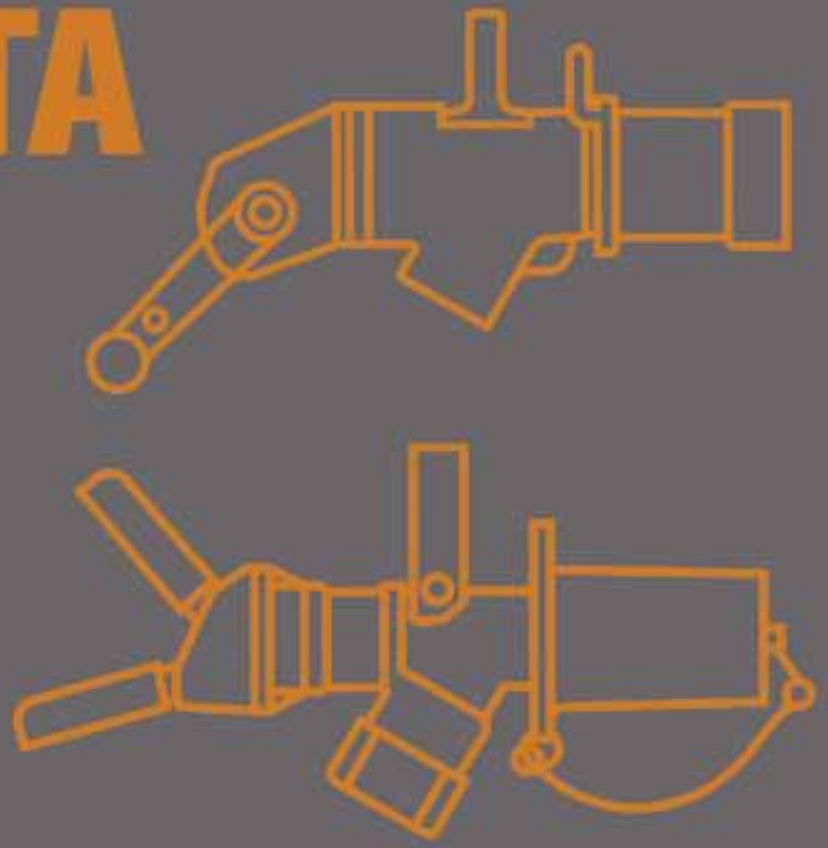

WIGGINS

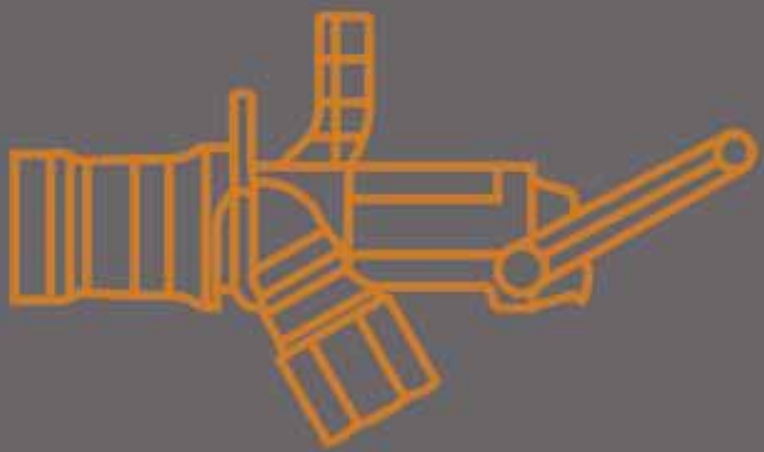

FLOMAX 


\section{Совершенствование организации и контроля рабочих процессов на угольном разрезе для снижения производственного риска} DOI: http://dx.doi.org/10.18796/0041-5790-2018-10-72-76

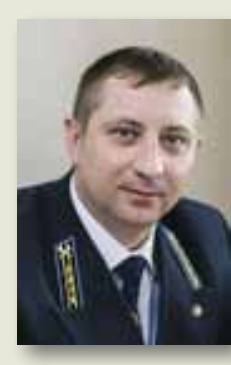

ЧЕРНОВ Александр Игоревич

Первый заместитель

генерального директора

000 «Читауголь»,

$674054, \mathrm{~cm}$. Голубичная,

Забайкальский край, Россия

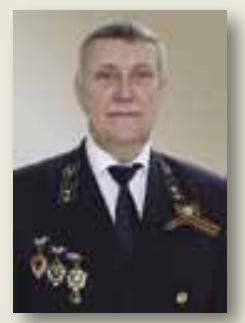

ЗИНОВЬЕВ Александр Владимирович

Директор по производству

АО «Разрез Назаровский»,

662200, г. Назарово, Россия

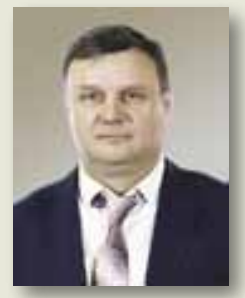

КРАВЧУК Игорь Леонидович

Доктор техн. наук, директор

Челябинского филиала ИгД УрО РАН,

директор ООО «НИИОГР»

по безопасности горного производства, 454048, г. Челябинск, Россия,

e-mail:kravchuk65@mail.ru

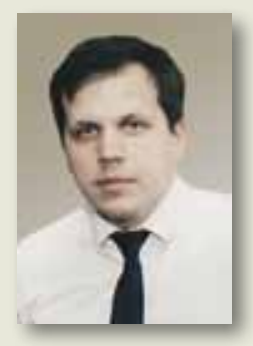

\section{СмолИн Антон Вячеславович}

Канд. техн. наук,

научный сотрудник ООО «НИИОГР»,

454048, г. Челябинск, Россия,

e-mail:89507458464@mail.ru

В статье представлены результаты системного анализа несчастного случая с машинистом экскаватора 000 «Читауголь». Выявлено, что сочетания неблагоприятных организационных и поведенческих факторов, допускаемые в системе деятельности персонала предприятия, являются источником высоких производственных рисков. Предложен комплекс мер по совершенствованию организации и контроля рабочих процессов на основе использования закономерностей возникновения и развития опасных производственных ситуаций, реализация которых позволит снизить риск травм и аварий.

\begin{abstract}
Ключевые слова: организация и контроль рабочих прочессов, опасная производственная ситуачия, производственный риск, природа травматизма, причины несчастного случая.
\end{abstract}

\section{ВВЕДЕНИЕ}

В условиях конкурентной борьбы угледобывающие предприятия вынуждены интенсифицировать производственные процессы, как правило, путем увеличения производительного времени и снижения времени, затрачиваемого на вспомогательные операции. При этом наибольшее количество несчастных случаев происходит именно на вспомогательных операциях. Это касается и операций по обслуживанию экскаваторного оборудования. Поэтому разработка комплекса мер по снижению производственного риска при выполнении таких операций представляется актуальной задачей $[1,2,3,4,5]$.

\section{ОРГАНИЗАЦИЯ И КОНТРОЛЬ РАБОЧИХ ПРОЦЕССОВ}

Основой для формирования такого комплекса мер по снижению производственного риска стали результаты анализа несчастного случая с машинистом экскаватора, происшедшего на разрезе ООО «Читауголь» 04.01.2018.

Хронология событий, приведших к несчастному случаю, следующая:

- 04.01.2018 в первую смену экипажу экскаватора ЭШ10/70 был выдан наряд на выполнение работ по обработке откоса борта и профилировке водосборника. В течение смены возникла необходимость замены высоковольтного кабеля, питающего экскаватор. Наряд на замену и подключение высоковольтного кабеля был выдан заместителем начальника горного участка и оформлен в журнале оперативных переключений, с которым под роспись были ознакомлены машинист экскаватора (1951 г. р., стаж 32 года) и помощник машиниста (1971 г. р., стаж 6 лет);

- в 12 ч 30 мин. экскаватор был остановлен для проведения рыхления мерзлоты кромки уступа бульдозером. Машинист остановил экскаватор стрелой от забоя, чтобы не мешать работе бульдозера, а ковш оставил в поднятом положении «на растяг», что является нарушением требования п. 3.2.23. Инструкции по охране труда для машиниста экскаватора;

- в 14 ч 00 мин. на тракторе К-702 был подвезен необходимый отрезок высоковольтного кабеля для замены, после чего экскаватор в 14 ч. 05 мин. с поднятым над землей ковшом был обесточен, и машинисты начали замену вы- 


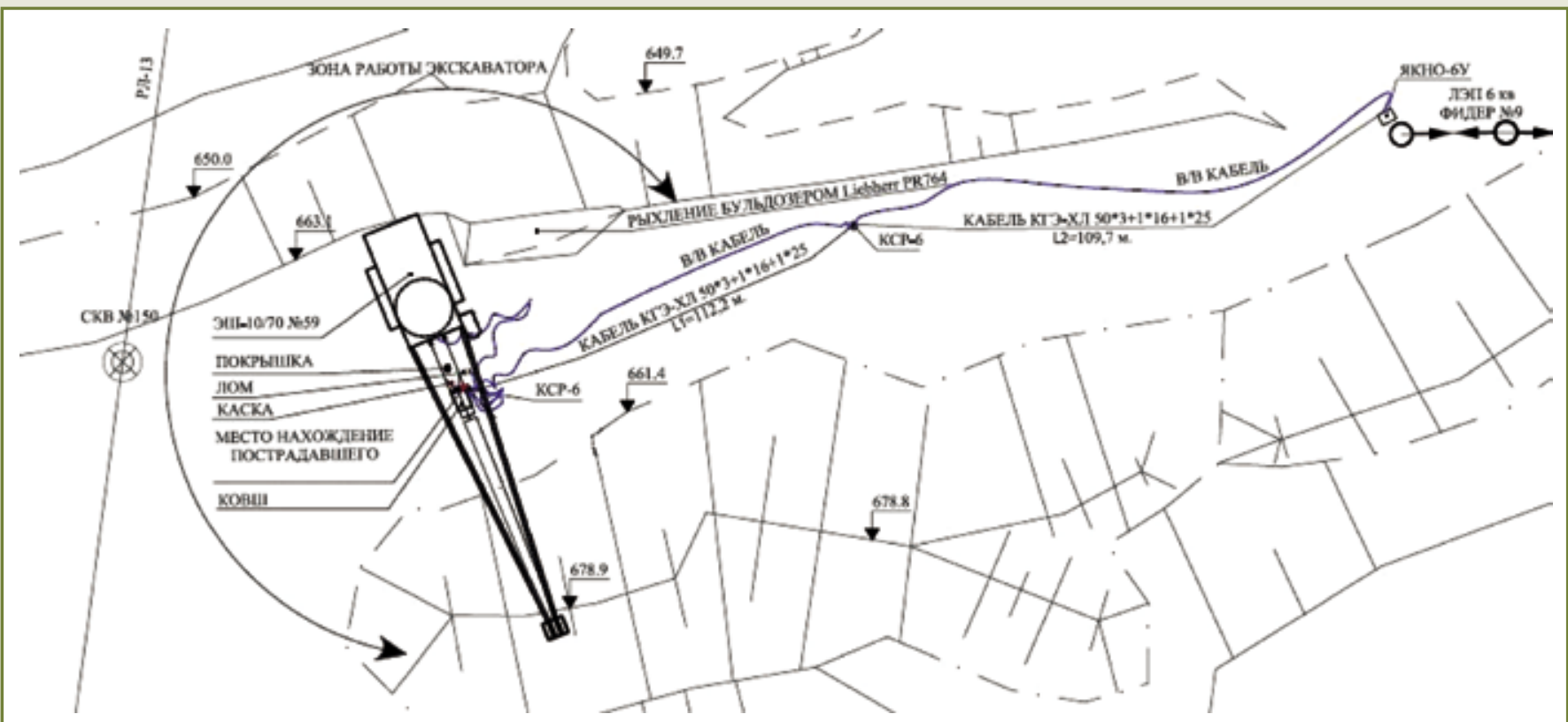

Puc. 1. Схема места несчастного случая

соковольтного кабеля. При подключении привезенного кабеля в соединительную коробку, находящуюся рядом с поднятым ковшом, машинист экскаватора начал прикручивать хомут крепления кабеля, оказавшись под ковшом. В этот момент ковш экскаватора начал самопроизвольное движение вниз и придавил машиниста к земле;

- в 14 ч 30 мин. горному диспетчеру поступило сообщение по радиосвязи о том, что машинист экскаватора получил травму. Немедленно на место происшествия была вызвана скорая медицинская помощь;

- в 14 ч 50 мин. прибыла скорая медицинская помощь, врач констатировал смерть пострадавшего.

Схема места несчастного случая представлена на рис. 1.
Для того чтобы предотвратить возникновение подобных случаев в будущем, необходимо определить причинноследственные связи, которые привели к негативному событию. С этой целью был проведен системный анализ этого негативного события на основе использования закономерностей зарождения и развития опасной производственной ситуации (ОПС) $[6,7,8,9]$. Данный анализ позволил выделить группы причин по природе их происхождения. Такая группировка позволила увидеть, что организационные причины, появившиеся до начала смены, послужили обстоятельствами, которые, в свою очередь, обусловили организационные причины, появившиеся уже во время смены. Сложившаяся таким образом ситуация повлияла на пове-

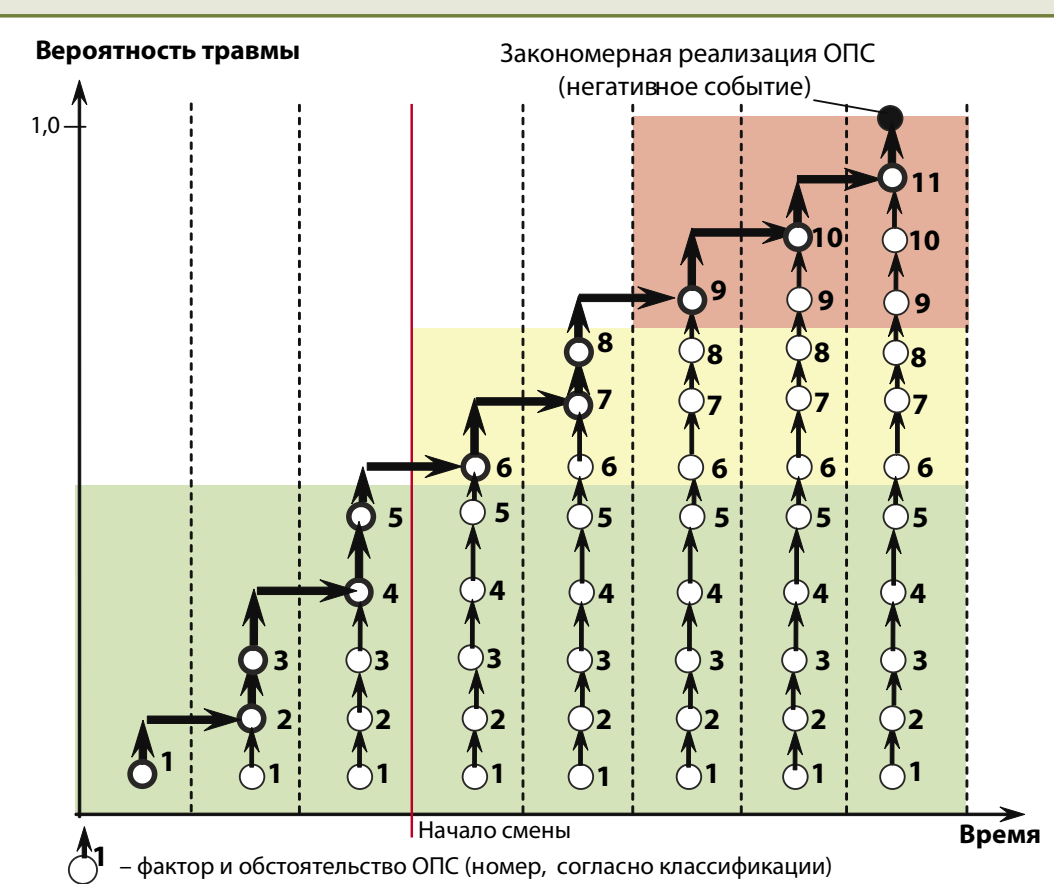

- поведенческие факторы (стадия реализации ОПС)

- организационные факторы, которые появились во время смены (стадия развития ОПС)

- организационные факторы , которые появились до начала смены (стадия зарождения ОПС)

Puс. 2. Схема реализации несчастного случая с машинистом экскаватора ЭШ 10/70 дение работников, которое и стало закономерным завершением этой цепи событий (рис. 2).

- Организачионные причины (обстоятельства), которые появились до начала смены и объективно не могли быть устранены участниками производственного процесса. К ним относятся:

1 - недостаточное знание экипажем экскаватора и механиками участка порядка регулировки и проверки тормозной системы;

2 - эксплуатация тормозной системы с отклонениями от требуемых параметров;

3 - совмещение технологических операций (работа бульдозера и переключение высоковольтного кабеля), которые не воспринимаются участниками процесса как ОПС;

4 - отсутствие информации о необходимости переключения кабеля перед началом смены; 
5 - ненадлежащие подготовка, выдача, организация и контроль исполнения наряд-задания: не предусмотрены и, соответственно, плохо подготовлены работы по переключению высоковольтного кабеля;

- Организационные причины (факторы), которые появились во время смены и которые могли быть устранены участниками производственного проuecca:

6 - в распоряжении на выполнение работы по переключению кабеля не было акцентировано внимание на осуществлении работ в зоне действия бульдозера и не было указания установки ковша на землю;

7 - отсутствие надлежащего контроля за выполнением операций со стороны ИТР (механиков, горного мастера);

8 - рабочее место для производства работ не было подготовлено: соединительная коробка находилась под ковшом экскаватора;

- Причины, обусловленные низкой дисциплиной и поведением машиниста:

9 - невыполнение инструкции по ОТ машинистом экскаватора (при остановке экскаватора ковш не установлен на землю);

10 - машинист экскаватора не отреагировал на замечание помощника: не работать под ковшом экскаватора (взаимная страховка не сработала из-за соблюдения субординации);

11 - производство работ под ковшом экскаватора.

Как видно из выявленной природы, несчастный случай/ негативное событие с машинистом экскаватора произошел вследствие сочетания неблагоприятных организационных причин и «человеческого фактора», допущенного в системе деятельности персонала предприятия.

Анализ причинно-следственных связей, с использованием закономерностей зарождения, развития и реализации ОПС, показывает, что причины 1-5 относятся к стадии зарождения ОПС. Данная группа причин является следствием низкого качества организации и контроля рабочих процессов на предприятии.

Как правило, эту группу причин менеджмент горнодобывающих предприятий не устраняет, так как не воспринимает их как источник зарождения ОПС. В анализируемом случае устранение этих причин в течение рабочей смены не представлялось возможным.

Группа организационных причин (6-8), обусловившая стадию развития ОПС, является в основном следствием недостаточной квалификации руководителей, ответственных за организацию и контроль работы в смене.

Наличие этой группы организационных причин объясняется в основном тем, что линейный персонал не распознал зарождающуюся ОПС и, как следствие, не предусмотрел меры по недопущению ее развития. При выдаче наряда не были проработаны и, соответственно, при выполнении операций не были применены безопасные приемы работы, обеспечивающие невозможность реализации ОПС в негативное событие.

Группа поведенческих причин (9-11) сформировала стадию реализации ОПС. Они проявили себя в следующем:

- неверная оценка риска и своих возможностей;

- нарушение правил безопасности;

- несработавшая система взаимоконтроля экипажа экскаватора;

• нерациональные приемы труда.
Данная группа причин трудноуправляема, поскольку требует специальных знаний в области психологии, которыми руководители всех уровней управления предприятия в необходимой мере не обладают.

Из этого анализа становится понятной организационная и поведенческая реакция людей на реальные условия осуществления работ. Таким образом, выявляется логическая цепь событий (организационных решений и поведенческих аспектов), приведших к травме. В этой цепи вскрываются как вполне логичные (закономерные), так и алогичные действия людей: не ясно, почему машинист экскаватора не отреагировал на замечание помощника и не развернул соединительную коробку так, чтобы выполнять операцию не под ковшом. Для предотвращения подобных несчастных случаев необходимо устранить условия (обстоятельства), составляющие именно логическую часть этой цепи событий.

Причины происшедшего несчастного случая обусловлены существованием системных дефектов в организации деятельности персонала предприятия и, прежде всего, его руководства. Они были выявлены ранее и, как показывает практика, характерны для горнодобывающих предприятий [7]:

І. Качество процесса, обеспечивающее безопасность, эффективность и социальную привлекательность труда, не является главным личным приоритетом руководителей;

II. Функциональность службы ОТ и ПК недостаточна для организации и контроля деятельности персонала предприятия по снижению производственных рисков в зоне его ответственности;

III. Руководители всех уровней управления, как правило, не рассматривают отклонения в производственных процессах как зарождение ОПС и, как следствие, не видят и не контролируют их;

IV. Существующая система обучения и подготовки квалификации работников не соответствует реальным производственным задачам;

V. Нарядная система, от руководителя до рабочего, не воспринимается и, соответственно, не используется в качестве основного инструмента организации и контроля безопасной и эффективной работы в смене.

Сопоставление причин несчастного случая и системных дефектов в обеспечении безопасности подтвердило их связь (табл. 1). Красным цветом обозначено значимое влияние системного дефекта на возникновение причины несчастного случая (фактора ОПС), желтым - менее значимое.

Проведенный анализ позволил выявить влияние системных дефектов в деятельности персонала предприятия на формирование и развитие причин негативного события. Снизить это влияние возможно только налаженной, постоянной, целенаправленной работой по повышению качества организации и контроля рабочих процессов [10, 11, 12]. Комплекс мер по повышению качества организации и контроля рабочих процессов на разрезе ООО «Читауголь» приведены в табл. 2.

\section{ЗАКЛЮЧЕНИЕ}

Применение методического подхода к внутреннему расследованию причин несчастного случая на основе закономерностей зарождения, развития и реализации ОПС позволяет вскрыть глубокие системные причины травмирования и понять природу травматизма. Устранить систем- 
Связь системных дефектов и причин несчастного случая

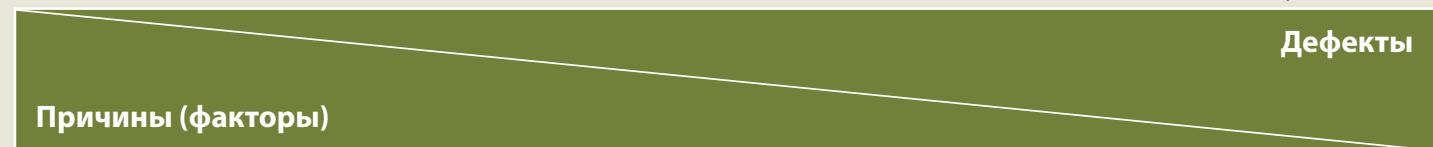

1 - недостаточное знание экипажем экскаватора и механиками участка порядка регулировки и проверки тормозной системы

2 - эксплуатация тормозной системы с отклонениями от требуемых параметров

3 - совмещение технологических операций (работа бульдозера и переключение высоковольтного кабеля), которое не воспринимается участниками процесса как ОПС

4 - отсутствие информации о необходимости переключения кабеля перед началом смены

5 - ненадлежащие подготовка, выдача, организация и контроль исполнения наряд-задания: не предусмотрены и, соответственно, плохо подготовлены работы по переключению высоковольтного кабеля 6 - в распоряжении на выполнение работы по переключению не было акцентировано внимание на работе в зоне бульдозера и не было указания установки ковша на землю

7 - отсутствие надлежащего контроля за выполнением операций со стороны ИТР (механиков, горного мастера)

8 - рабочее место для производства работ не было подготовлено: соединительная коробка находилась под ковшом экскаватора

9 - невыполнение инструкции по ОТ машинистом экскаватора (при остановке ковш не установлен на землю)

10 - машинист экскаватора не отреагировал на замечание помощника: не работать под ковшом экскаватора (взаимная страховка не сработала из-за соблюдения субординации)

11 - производство работ под ковшом экскаватора

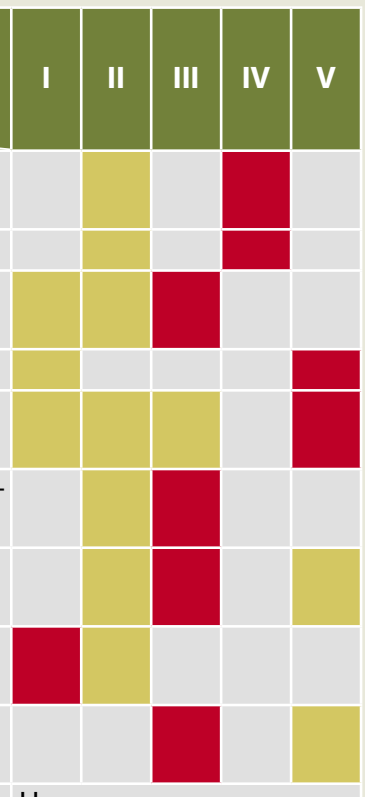

Не являются следствием системных дефектов

\section{Комплекс мер совершенствования организации и контроля рабочих процессов}

Таблича 2

\section{Класс причин}

\section{Организационные}

Поведенческие

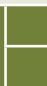

Организовать постоянный процесс обучения, сформировать индивидуальные программы повышения квалификации. Сформировать и обеспечить работу института наставничества, позволяющего решать актуальные для предприятия задачи безопасности и эффективности производства.

Разработать для каждого рабочего места перечень необходимой информации для выдачи наряда. Обеспечить ее доведение до каждого рабочего в каждую смену.

Выявить все совмещаемые операции в производственном процессе, разработать и реализовать порядок их выполнения.

Организовать систематическое тестирование работников на склонность к риску, осуществлять выдачу нарядов с учетом результатов тестов на склонность к рискованному поведению. Обратить особое внимание на работу малоопытных и сверхопытных сотрудников для организации соответствующих страховок.

\section{Контроль}

Обеспечить непрерывный мониторинг состояния процессов по качеству их организации и контроля.

О̆ Обеспечить систематическую оценку качества выдачи наряда.

Обеспечить выполнение совмещаемых операций под контролем ИТР.

Поведенческие аудиты безопасности, позволяющие выявлять отношение работника к обеспечению безопасности и мотивировать к снижению производственных рисков в его зоне ответственности. ные причины отдельными мероприятиями невозможно, необходимо разработать и реализовывать на постоянной основе полноценный комплекс мер по совершенствованию организации и контроля рабочих процессов. Его реализация в сочетании с соответствующей подготовкой и развитием персонала приведет к существенному снижению производственного риска.

\section{Список литературы}

1. Подход к повышению безопасности труда посредством стандартизации процессов и операций ремонта карьерных автосамосвалов: опыт ОАО «Разрез Тугнуйский» / В.Н. Кулецкий, А.И. Каинов, А.В. Горохов и др. //Уголь. 2013. № 7. C. 46-49. URL: http://www.ugolinfo.ru/Free/702013.pdf (дата обращения: 15.09.2018).

2. Кулецкий В.Н., Жунда С.В., Галкин А.Вал. Формирование эффективной системы производственного контроля на разрезе «Тугнуйский» для устранения условий труда, при которых возможны групповые, смертельные и тяжелые травмы // Уголь. 2017. № 2. С. 23-27. URL: http://www. ugolinfo.ru/Free/022017.pdf (дата обращения: 15.09.2018).

3. Komljenovic Dragan, Loiselle Georges, Kumral Mustafa. Organization: A new focus on mine safety improvement in a complex operational and business environment // International Journal of Mining Science and Technology. 2017. N 27. Pp. 617-625. URL: http://www.elsevier.com/locate/ijmst (дата обращения: 15.09.2018).

4. Emily Joy Haas, Patrick Yorio. Exploring the state of health and safety management system performance measurement in mining organizations // Safety Science. March 2016. Vol. 83. Pp. 48-58.

5. Tan Chong, Song Yi, Che Heng. Application of set pair analysis method on occupational hazard of coal mining // Safety Science. February 2017. Vol. 92. Pp. 10-16. 
6. Лисовский В.В. Закономерности развития опасных производственных ситуаций на примере горнодобывающих предприятий. В кн. Совершенствование деятельности по обеспечению безопасности производства на угледобывающих предприятиях // Горный информационно-аналитический бюллетень. 2016. № 12 (спец. выпуск № 70). С. 3-16.

7. Роль руководителя и персонала в обеспечении безопасности производства / В.Б. Артемьев, А.И.Добровольский, В.В. Лисовский и др. Отдельная статья Горного информационно-аналитического бюллетеня. М.: Горная книга, 2017. 47 с. (Сер. «Б-ка горного инженера-руководителя». Вып. 32).

8. Бережецкий Н.М., Довженок А.С., Полещук М.Н. Поиск новых возможностей повышения безопасности производства в ООО «Назаровское ГМНУ» // Уголь. 2017. № 7. C. 48-51. URL: http://www.ugolinfo.ru/Free/072017.pdf (дата обращения: 15.09 .2018$)$.
9. Организационный аспект обеспечения безопасности производства на горнодобывающих предприятиях / В.Б. Артемьев, В.А. Галкин, А.М. Макаров и др. // Безопасность труда в промышленности. 2016. № 12. С. 20-26.

10. Организация работы по повышению уровня безопасности производства в АО «Разрез Тугнуйский» / В.Н. Кулецкий, С.В. Жунда, А.С. Довженок, А.В. Галкин // Уголь. 2016. № 11.C. 58-63. URL: http://www.ugolinfo.ru/Free/112016.pdf (дата обращения: 15.09.2018).

11. Перекрестный аудит безопасности труда как средство снижения риска травмирования персонала / В.Н. Кулецкий, В.В. Лисовский, С.В. Жунда и др. // Уголь. 2018. № 3. С. 52-55. doi: 10.18796/0041-5790-2018-5-51-57.

12. Jules Arntz-Gray. Plan, Do, Check, Act:The need for independent audit of the internal responsibility system in occupational health and safety // Safety Science. April 2016. Vol. 84. Pp. 12-23.

UDC 658.5:622.33.012.3:658.382.3:622.8 ๑ A.I. Chernov, A.V. Zinoviev, I.L. Kravchuk, A.V. Smolin, 2018

PRODUCTION SETUP ISSN 0041-5790 (Print) • ISSN 2412-8333 (Online) • Ugol' - Russian Coal Journal, 2018, № 10, Pp. 72-76

\section{Title}

\section{IMPROVING THE ORGANIZATION AND CONTROL OF WORK PROCESSES ON THE COAL MINE TO REDUCE OCCUPATIONAL HAZARDS}

DOI: http://dx.doi.org/10.18796/0041-5790-2018-10-72-76

\section{Authors}

Chernov A.I. ${ }^{1}$, Zinoviev A.V. ${ }^{2}$, Kravchuk I.L. ${ }^{3,4}$, Smolin A.V.

1 "Chitaugol" LLC, Golubichnaya village, Zabaykalsky Krai, 674054, Russian Federation

2 "Nazarovsky open-pit mine" JSC, Nazarovo, 662200, Russian Federation

${ }^{3}$ Chelyabinsk Branch of Institute of Mining of Ural Branch of RAS, Chelyabinsk, 454048, Russian Federation

${ }^{4}$ Institute of efficiency and safety of mining production ("NIIOGR" LLC), Chelyabinsk, 454048, Russian Federation

\section{Authors' Information}

Chernov A.I., First Deputy General Director

Zinoviev A.V., Director on Production

Kravchuk I.L., Doctor of Engineering Sciences, Director Chelyabinsk Branch,

Director on Mining Production Safety, e-mail: kravchuk65@mail.ru

Smolin A.V., PhD (Engineering), research associate,

e-mail: 89507458464@mail.ru

\section{Abstract}

The paper presents system analysis results of the accident with "Chitaugol" LLC shovelman. It was revealed that combinations of unfavorable organizational and behavioral factors occurring in the enterprise personnel performance system are a source of high occupational hazards. A set of measures is proposed to improve the organization and control of work processes by using hazardous industrial situations occurrence and development patterns, the implementation of which will reduce the risk of injuries and accidents.

\section{Keywords}

Organization and control of work processes, Dangerous situation in the workplace, Occupational hazard, Nature of injuries, Causes of accident

\section{References}

1. Kuletsky V.N., Kainov A.I., Gorokhov A.V., Jankov P.P. \& Galkin A.V. Podkhod k povysheniyu bezopasnosti truda posredstvom standartizatsii protsessov i operatsiy remonta kar'ernykh avtosamosvalov: opyt OAO "Razrez Tugnuyskiy" [Strategy of labour safety improvement using the standardization of procedures and operations of open-pit dump trucks: experience of "Tugnuysky" open-pit mine]. Ugol' - Russian Coal Journal, 2013, No. 7, Pp. 46-49. Available at: http:// www.ugolinfo.ru/Free/702013.pdf (accessed 15.09.2018).

2. Kuletsky V.N., Zhunda S.V. \& Galkin A.Val. Formirovanie effektivnoy sistemy proizvodstvennogo kontrolya na razreze «Tugnuyskiy» dlya ustraneniya usloviy truda, pri kotorykh vozmozhny gruppovye, smertel'nye i tyazhelye travmy [Efficient production monitoring system arrangement in"Tugnuysky"open-pit mine for elimination of the labor conditions, raising the possibility of group, fatal and severe injuries]. Ugol' - Russian Coal Journal, 2017, No. 2, Pp. 23-27. Available at: http://www.ugolinfo.ru/Free/022017.pdf (accessed 15.09.2018).

3. Komljenovic Dragan, Loiselle Georges \& Kumral Mustafa. Organization: A new focus on mine safety improvement in a complex operational and business environment. International Journal of Mining Science and Technology, 2017 No. 27, Pp. 617-625. Available at: http://www.elsevier.com/locate/ijmst (accessed 15.09.2018).
4. Emily Joy Haas \& Patrick Yorio. Exploring the state of health and safety management system performance measurement in mining organizations. Safety Science, March 2016, Vol. 83, Pp. 48-58.

5. Tan Chong, Song Yi \& Che Heng. Application of set pair analysis method on occupational hazard of coal mining. Safety Science, February 2017, Vol. 92, Pp. 10-16. 6. Lisovskiy V.V. Zakonomernosti razvitiya opasnykh proizvodstvennykh situatsiy na primere gornodobyvayushchikh predpriyatiy [Laws of development of dangerous situations in the workplace by the example of mining enterprises]. In the book: Sovershenstvovanie deyatelnostipo obespecheniyu bezopasnostiproizvodstva naugledobyvayushchih predpriyatiyah [Improvement of activities to ensure occupational safety at coal producers]. Gornyy Informacionno-Analiticheskiy ByulletenMining Information-Analytical Bulletin, 2016, No. 12 (special issue No. 70), Pp. 3-16. 7. Artemiev V.B., Dobrovolskiy A.I., Lisovskiy V.V. et al. Rol'rukovoditelya i personala v obespechenii bezopasnosti proizvodstva. Otdel'naya stat'ya [Management and personnel role in production safety. Separate article]. Gornyy InformatsionnoAnaliticheskiy Byulleten' - Mining Information-Analytical Bulletin, 2017, Issue 32, 47 p. (Seriya"B-ka gornogo inzhenera-rukovoditelya -"Mining engineer - manager's library" series).

8. Berezhetskiy N.M., Dovzhenok A.S. \& Poleshchuk M.N. Poisk novykh vozmozhnostey povysheniya bezopasnosti proizvodstva v OOO «Nazarovskoe GMNU» [In search of new ways of industrial safety improvement in "Nazarovskoye GMNU", LLC]. Ugol'-Russian Coal Journal, 2017, No. 7, Pp. 48-51. Available at: http://www. ugolinfo.ru/Free/072017.pdf (accessed 15.09.2018).

9. Artemiev V.B., Galkin V.A., Makarov A.M. et al. Organizatsionnyy aspekt obespecheniya bezopasnosti proizvodstva na gornodobyvayushchikh predpriyatiyakh [Organizational aspect of ensuring occupational safety at mining enterprises]. Bezopasnost Truda v Promyshlennosti - Safety in Industry, 2016, No. 12, Pp. 20-26. 10. Kuletsky V.N., Zhunda S.V., Dovgenok A.S. \& Galkin A.Val. Organizatsiya raboty po povysheniyu urovnya bezopasnosti proizvodstva v AO "Razrez Tugnuyskiy" [Production setap on improving production safety in "Tugnuysky" open-pit mine]. Ugol' - Russian Coal Journal, 2016, No. 11, Pp. 58-63. Available at: http://www. ugolinfo.ru/Free/112016.pdf (accessed 15.09.2018).

11. Kuletsky V.N., Lisovskiy V.V., Zhunda S.V., Dovzhenok A.S. \& Galkin A.Val. Perekrestnyy audit bezopasnosti truda kak sredstvo snizheniya riska travmirovaniya personala [Cross-audit of labour safety as a means of the personnel injury risk reducing]. Ugol' - Russian Coal Journal, 2018, No. 3, Pp. 52-55. doi: 10.18796/0041-5790-2018-5-51-57.

12. Jules Arntz-Gray Plan, Do, Check, Act: The need for independent audit of the internal responsibility system in occupational health and safety. Safety Science, April 2016, Vol. 84, Pp. 12-23. 


\section{Снижение экологического ущерба экосистемам за счет использования межсланцевой глины и золошлакового материала в производстве легковесного кирпича и пористого заполнителя}

DOI: http://dx.doi.org/10.18796/0041-5790-2018-10-77-83

В работе показано, что в настоящее время в России сформировалась экологически несбалансированная инвестиционная политика, которая ведет к росту диспропорций между природоэксплуатирующими и перерабатывающими, обрабатывающими и инфраструктурными отраслями экономики во многом из-за недоучета экологического фактора в макроэкономической политике, что приводит к дальнейшей деградации окружающей среды и исчерпанию природных ресурсов. Поэтому важной чертой новой модели должна стать экологическая устойчивость. Одним из наиболее перспективных направлений использования отходов производств является вовлечение их во вторичный оборот в качестве вторичных материальных или энергетических ресурсов. За счет вовлечения промышленных отходов в производство теплоизоляционных материалов возможно кардинально изменить параметры сырьевой базы России, что способствует также снижению экологической напряженности в регионах. Использование отходов топливно-энергетического комплекса: межсланцевой глины и золошлакового материала в производстве теплоизоляционных изделий способствует утилизации промышленных отходов, охране окружающей среды, расширению сырьевой базы для получения керамических строительныхматериалов. Утилизация промышленных отходов способствует развитию «зеленой» экономики. Под «зеленой» экономикой в настоящей работе подразумевается производство различного рода очистного оборудования, утилизация вторичных ресурсов и отходов, оказание экологических услуг и пр.

Ключевые слова: охрана окружающей среды, утилизация отходов, межсланцевая глина, золошлаковый материал, легковесный кирпич, пористый заполнитель.

\section{ВВЕДЕНИЕ}

В России сформировалась экологически несбалансированная инвестиционная политика, которая ведет к росту диспропорций между природоэксплуатирующими и перерабатывающими, обрабатывающими и инфраструктурными отраслями экономики во многом из-за недоучета экологического фактора в макроэкономической политике, что приводит к дальнейшей деградации окружающей среды и исчерпанию природных ресурсов. Поэтому важной чертой новой модели должна стать экологическая устойчивость.

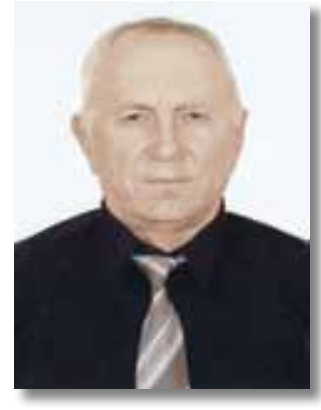

\author{
АБДРАХИМОВ \\ Владимир Закирович \\ Професссор ФГБОУ ВО «Самарский \\ государственный экономический \\ университет» (СГЭУ), \\ 443090 , г. Самара, Россия, \\ тел.: +7 (846) 337-58-92, \\ e-mail:3375892@mail.ru
}

Из-за хищнического обращения с природой в настоящее время в ней обнаружились существенные негативные, часто необратимые, сдвиги, поэтому человечеству следует понять, что под действием антропогенных факторов природная ситуация катастрофически быстро меняется. Самое главное - человечеству в настоящее время нужно осознать себя активной частью природы, единство с ней, понять себя и свое место в мире живого $[1,2,3]$.

В настоящее время в России сформировались «антиустойчивые» тенденции развития:

- во-первых, существует серьезное воздействие загрязнения окружающей среды на здоровье человека;

- во-вторых, произошли структурные сдвиги в экономике, которые значительно повысили удельный вес природоэксплуатирующих и загрязняющих отраслей;

- в-третьих, возросли экологические риски в связи с высоким физическим износом оборудования.

Несмотря на многократные тезисы об инновациях, модернизации и диверсификации, хозяйство страны в последние годы превращалось во все более экспортносырьевое. Следует отметить, что кризис наглядно показал колоссальную зависимость российской экономики от эксплуатации и продажи природного сырья. Поэтому в экономике России наблюдается рост удельного веса отраслей с сильным негативным экологическим воздействием, а по ряду направлений возросло загрязнение окружающей среды.

Следует отметить, что многочисленные попытки исправить экологическую ситуацию привели к обратному эффекту, потому что «доход» от экологии для государственного бюджета напрямую зависит от того, сколько отходов выбрасывают предприятия в окружающую среду. Сам принцип «чем больше выбросили отходов - тем 
лучше» мог бы работать, если бы собираемые с предприятий средства шли непосредственно на мероприятия по восстановлению в России среды обитания. Однако это совсем не так, так как экологическая ситуация, по данным Минприроды России, от года к году ухудшается, количество и острота социальных конфликтов на экологической почве возрастают.

Действующее природоохранное законодательство содержит дефекты (противоречия, пробелы), наличие которых при применении законов ведет к возникновению такого явления, как «абсурды» [4]. Под «абсурдом» понимается противоречивая нормоприменительная практика, которая иррациональна, невыгодна ни государству, ни субъектам хозяйственной деятельности, ни населению и создает значительные административные барьеры и условия для возникновения коррупции.

Важно отметить систематический характер возникновения «абсурдов». Они появляются, сохраняются и распространяются вследствие дефектности всей системы природоохранного регулирования, а не ошибок отдельных разработчиков. Как правило, противоречия, возникающие на уровне одного федерального закона («абсурд» верхнего уровня) порождают коллизии в других федеральных законах или на уровне подзаконных актов и методик («абсурд» низкого уровня) [4].

Устранение административных барьеров обоих уровней требует внесения целостных, согласованных изменений в нормативные правовые акты, что зачастую характеризуется сложностями во взаимодействии между субъектом, заинтересованным в устранении «абсурда», и субъектом, обладающим полномочиями по его устранению.

\section{ОТХОДЫ ТОПЛИВНО-ЭНЕРГЕТИЧЕСКОГО КОМПЛЕКСА}

Топливно-электроэнергетический комплекс является одним из основных «загрязнителей» окружающей природной среды. Это выбросы в атмосферу (48\% всех выбросов в атмосферу), сбросы сточных вод (36\% всех сбросов), а также образование твердых отходов (30\% всех твердых загрязнителей) [5].

К отходам топливно-энергетической промышленности относятся продукты, получаемые в виде отходов при добыче, обогащении и сжигании твердого топлива [6]. Эту группу отходов разделяют по источнику образования, виду топлива, числу пластичности минеральной части отходов, содержанию горючей части, зерновому составу, химико-минералогическому составу, степени плавкости, интервалу размягчения, степени вспучиваемости и т.д.

В настоящее время, эффективность работы всех отраслей промышленности необходимо оценивать с точки зрения баланса между массой основного продукта и объемом образуемых техногенных отходов. Наиболее неблагополучными в этом плане являются предприятия топливно-энергетического комплекса, а именно: тепловые электрические станции (ТЭС), являющиеся источниками массированных атмосферных выбросов и крупнотоннажных твердых отходов, и обогатительные предприятия $[7,8,9,10,11,12]$.

Значительные объемы золы и шлака образуются при сжигании угля на тепловых электростанциях. По имеющейся оценке, в отвалах ТЭЦ и ТЭС находится более
1 млрд т этих отходов, а количество золошлаковых отходов удваивается в среднем каждые 10 лет [7, 8, 9, 10, 11, 12]. Ежегодный выход золошлаковых отходов достигает примерно 70 млн т. В среднем площадь земель, занятых золоотвалами современной тепловой электростанции, составляет от 500 до 1000 га.

Длительное хранение отходов теплоэнергетики в золоотвалах способствует попаданию в воду и почву вредных веществ и ионов тяжелых металлов. По оценкам авторов работ [7, 8, 9, 10, 11, 12], антропогенная составляющая формирования качества поверхности вод уже соизмерима с природной составляющей, что представляет угрозу устойчивому водопользованию. Совершенно очевидно, что нужно снижать антропогенную нагрузку посредством внедрения региональных нормативов, изменения платы за загрязнение водных объектов и использования отходов энергетики в производстве строительных материалов.

Зола, получающаяся после сжигания жидкого и особенно твердого топлива, является многотоннажным отходом энергетики и требует обязательной утилизации. Имеются данные, что тепловые электростанции в 2-4 раза сильнее загрязняют среду радиоактивными веществами, чем АЭС такой же мощности [7, 8, 9, 10, 11, 12]. В выбросах ТЭС содержится значительное количество металлов и их соединений. При пересчете на смертельные дозы в годовых выбросах ТЭС мощностью 1 млн кВт содержится алюминия и его соединений свыше 100 млн доз, железа - 400 млн доз, магния - 1,5 млн доз. Летальный эффект этих загрязнителей не проявляется только потому, что они попадают в организмы в незначительных количествах. Это, однако, не исключает их отрицательного влияния через воду, почву и другие звенья экосистем $[7,8,9,10,11,12]$.

\section{«ЗЕЛЕНАЯ» ЭКОНОМИКА}

Под «зеленой» экономикой подразумеваются производство различного рода очистного оборудования, утилизация вторичных ресурсов и отходов, оказание экологических услуг и пр. [13]. В этом случае «зеленая» экономика оказывается лишь частью «большой» экономики.

«Зеленая» экономика определяется структурами ООН как экономика, которая повышает благосостояние людей, обеспечивает социальную справедливость и при этом существенно снижает риски для окружающей среды и ее деградации $[13,14,15]$. Важными чертами такой экономики являются: эффективное использование природных ресурсов; сохранение и увеличение природного капитала; уменьшение загрязнения; низкие углеродные выбросы; предотвращение утраты экосистемных услуг и биоразнообразия. Например, в докладе ООН приводятся такие данные: переход к «зеленой» экономике позволит увеличить благосостояние населения, а также снизит риски негативного влияния на окружающую среду.

Модель формирования устойчивого экономического развития как социо-эколого-экономическая система включает в себя три сектора: природоэксплуатирующий; услуги; социо-экологический. Эта модель исследует безопасный с экологической точки зрения воспроизводственный цикл продукции. 
Первый сектор формирует экологически чистую сырьевую базу, что становится возможным за счет вложений активов извне, при этом не допускается использование вредных веществ, которые могут негативно воздействовать на окружающую среду и здоровье человека. В конечном итоге подобные вложения, основанные на технологических нормах производства, на данной стадии увеличивают число участвующих мощностей.

Важно помнить, что использование ресурса должно быть ориентировано на возрастание уровня жизни населения. Еще на стадии переработки сырья устанавливается число производств, участвующих в переработке экологически чистого сырья, а также производство данной продукции. Здесь же определяются предложения экологически чистых технологий для первого и второго секторов общественного производства, что является залогом совершенствования экологии.

Во втором секторе в структуре услуг, кроме традиционных их видов, также участвуют все виды экологических услуг. Особое значение приобретают экологическое образование, повышение уровня культуры в целом.

Третий сектор в данной модели включает потребление экологических продуктов и услуг, формирование экологической культуры общества. На этой стадии потребления формируется спрос на экологическую продукцию. Сбережение природной среды и ее ресурсов требует капитальных вложений.

\section{ТЕПЛОИЗОЛЯЦИОННЫЕ МАТЕРИАЛЫ}

Легковесный кирпич и пористый материал относятся к классу керамических теплоизоляционных материалов. Одной из актуальных задач промышленности теплоизоляционных композиционных материалов в настоящее время является производство изделий с высокой эффективностью, теплопроводность которых не более 0,25 Вт/ $\left(\mathrm{M} \cdot{ }^{\circ} \mathrm{C}\right)$. Производство и потребление таких теплоизоляционных материалов в России гораздо меньше, чем в странах Европы и Северной Америки, несмотря на то, что там во многих странах климат гораздо мягче.

Изменение нормативов по теплотехническим параметрам к ограждающим конструкциям способствует повышенному спросу на теплоизоляционные материалы. Применение теплоизоляционных материалов позволяет снизить толщину, массу стен и других ограждающих конструкций, что влечет за собой, соответственно, снижение общей стоимости строительства. Кроме того, сокращение потерь тепла в отапливаемых зданиях значительно уменьшает расход топлива, что особенно актуально в настоящее время.

Для получения теплоизоляционных материалов в керамические массы вводят выгорающие добавки, которые при низких температурах ведут себя аналогично отощающим добавкам (снижают сроки сушки), а при высоких температурах способствуют обжигу керамических изделий, снижают расход топлива, повышают пористость и уменьшают вес готовых изделий. К группе выгорающих добавок относятся различные виды твердого топлива, в частности антрацит, коксовая мелочь и др. [6]. Их могут вводить в состав шихты до 8-10\% по объему, то есть 50-80\% от общей потребности топлива на обжиг изделий. При наличии теплотворной способности в отходах топливно-энергетического комплекса более 2000 ккал/кг положительный эффект (марка кирпича не менее 100) достигается добавкой в шихту до 30-50\% отходов энергетики.

Производство керамических материалов - одна из самых материалоемких отраслей народного хозяйства, поэтому рациональное использование топлива, сырья и других материальных ресурсов становится решающим фактором ее успешного развития в условиях проводимой экономической реформы [1, 2, 5]. В связи с этим применение в керамических материалах отходов сырья приобретает особую актуальность.

Одним из наиболее перспективных направлений использования отходов производств является вовлечение их во вторичный оборот в качестве вторичных материальных или энергетических ресурсов [5]. За счет вовлечения промышленных отходов возможно кардинально изменить параметры сырьевой базы России. Использование техногенного сырья в производстве теплоизоляционных материалов способствует также снижению экологической напряженности в регионах [5].

Целью настоящей работы является разработка технологии утилизации промышленных отходов путем получения теплоизоляционного материала (легковесного кирпича) на основе межсланцевой глины и золошлакового материала без применения природных традиционных материалов.

\section{СЫРЬЕВЫЕ МАТЕРИАЛЫ \\ Межсланцевая глина.}

Для получения теплоизоляционного композиционного материала в качестве глинистого компонента использовалась межсланцевая глина [5]. Межсланцевая глина образуется при добыче горючих сланцев на сланцеперерабатывающих заводах (на шахтах). Межсланцевая глина является отходом горючих сланцев. По числу пластичности межсланцевая глина относится к высокопластичному глинистому сырью (число пластичности - 27-32) с истинной плотностью 2,55-2,62 г/ см Оксидный и поэлементный химические составы межсланцевой глины представлены в табл. 1, 2, фракционный состав - в табл. 3, а технологические свойства - в табл. 4.

Оксидный химический состав компонентов

\begin{tabular}{|c|c|c|c|c|c|c|c|}
\hline \multirow{2}{*}{ Компонент } & \multicolumn{7}{|c|}{ Содержание оксидов, мас. \% } \\
\hline & $\mathrm{SiO}_{2}$ & $\mathrm{Al}_{2} \mathrm{O}_{3}$ & $\mathrm{Fe}_{2} \mathrm{O}_{3}$ & $\mathrm{CaO}$ & MgO & $\mathbf{R}_{2} \mathbf{O}$ & П.п.п. \\
\hline Межсланцевая глина & $45-47$ & $13-14$ & $5-6$ & $11-13$ & $2-3$ & $3-4$ & $9-20$ \\
\hline Золошлаковый материал Тольяттинской ТЭС & $48-49$ & $16-17$ & $7-8$ & $3-4$ & $2-3$ & $0,1-0,3$ & $20-22$ \\
\hline
\end{tabular}


Поэлементный анализ компонентов

\begin{tabular}{|c|c|c|c|c|c|c|c|c|c|c|}
\hline \multirow{2}{*}{ Компонент } & \multicolumn{10}{|c|}{ Элементы } \\
\hline & $\mathbf{C}$ & 0 & $\mathbf{N a}$ & Mg & $\mathrm{Al}+\mathrm{Ti}$ & Si & $\mathbf{S}$ & $\mathbf{K}$ & $\mathbf{C a}$ & Fe \\
\hline Межсланцевая глина & 5,73 & 51,06 & 0,46 & 1,04 & 7,20 & 18,66 & 1,83 & 1,75 & 10,53 & 3,35 \\
\hline $\begin{array}{l}\text { Золошлаковый материал } \\
\text { Тольяттинской ТЭС }\end{array}$ & 6,4 & 51,08 & 1,09 & 0,4 & $10,5+1,44$ & 18,44 & 1,1 & 1,5 & 3,03 & 4,02 \\
\hline
\end{tabular}

Таблица 3

Фракционный состав компонентов

\begin{tabular}{|l|c|c|c|c|c|}
\multicolumn{1}{c|}{ Компонент } & \multicolumn{4}{|c|}{ Содержание фракций в \%, размер частиц в мм } \\
\cline { 2 - 6 } & $>\mathbf{0 , 0 6 3}$ & $\mathbf{0 , 0 6 3 - 0 , 0 1}$ & $\mathbf{0 , 0 1 - 0 , 0 0 5}$ & $\mathbf{0 , 0 0 5 - 0 , 0 0 1}$ & $<\mathbf{0 , 0 0 0 1}$ \\
\hline Межсланцевая глина & 5 & 7 & 12 & 14 & 62 \\
\hline Золошлаковый материал Тольяттинской ТЭС & 18,39 & 33,70 & 33,8 & 10,7 & 3,41 \\
\hline
\end{tabular}

Технологические показатели компонентов

\begin{tabular}{|l|c|c|c|c|}
\multicolumn{1}{c|}{ Компонент } & Теплотворная \\
\cline { 3 - 6 } & способность, ккал/кг & $\begin{array}{c}\text { Начало } \\
\text { деформации }\end{array}$ & Размягчение & $\begin{array}{c}\text { Жидкоплавкое } \\
\text { состояние }\end{array}$ \\
\hline Межсланцевая глина & 1100 & 1260 & 1290 & 1320 \\
\hline Золошлаковый материал Тольяттинской ТЭС & 2100 & 1300 & 1300 & 1390 \\
\hline
\end{tabular}

Глинистые минералы в межсланцевой глине в основном представлены монтмориллонитом с примесью гидрослюды, поэтому она вполне может заменить монтмориллонитовую глину при производстве пористого заполнителя, например керамзита.

\section{Золошлаковый материал Тольяттинской ТЭС.}

Для производства теплоизоляционных материалов в качестве отощителя и выгорающей добавки использовался золошлаковый материал Тольяттинской ТЭС [5]. Зола рыхлый материал черного или серого цвета. Кроме минеральных веществ в ней присутствует органическая составляющая.

Химический оксидный состав золошлакового материала представлен в табл. 1, поэлементный - в табл. 2, гранулометрический (фракционный) - в табл. 3.

Рентгенофазовый состав исследуемого золошлакового материала проводился на дифрактометре ДРОН-6 с использованием СоКа-излучения при скорости вращения столика с образцом 1 град/мин. На рис. 1 представлена рентгенограмма золошлакового материала, а на рис. 2 микроструктура.

На рентгенограмме для золошлакового материала характерны интенсивные линии кварца $(d / n=0,181 ; 0,234$; 0,334; 0,348 и 0,424 нм), присутствие линии $(d / n=0,184 ; 0,227 ; 0,251 ; 0,27$ и 0,365 нм) обусловлено гематитом, линии в золошлаке $(d / n=0,2042$; 0,26; 0,321; 0,375 и 0,483 нм) говорят о наличии анортита, линии $(d / n=0,211 ; 0,22$ и 0,339 нм) - муллита, линии $(d / n=0,246 ; 0,292 ; 0,313$ и 0,403) - кристобалита.

Минералогический состав золошлакового материала представлен следующими минералами, мас. \%: аморфизованное глинистое вещество - 10-20; органика - 20-25; сте- кловатые шарики - 45-65; кварц, полевой шпат - 5-15; кальцит - 3-5; гидрогранаты, муллит, оксиды железа 5-10, примеси - 3-7. Имея повышенное содержание органики, золошлаковый материал может использоваться в производстве керамических материалов и в качестве выгорающей добавки.

Наличие муллита $\left(3 \mathrm{Al}_{2} \mathrm{O}_{3} \cdot 2 \mathrm{SiO}_{2}\right)$ в исследуемом золошлаке будет способствовать и образованию муллита при обжиге керамического кирпича.

\section{Жидкое стекло.}

Распространенность сырьевой базы для получения теплоизоляционных материалов на основе жидкостекольных композиций обеспечивается самой природой, в которой ближайший аналог углерода - кремний - является третьим (после кислорода и водорода) по распространенности элементом: на его долю приходится 16,7\% от общего числа атомом земной коры $[16,17]$. Если углерод можно рассматривать как основной элемент для всей органической жизни, то кремний играет подобную же роль по отношению к твердой земной коре, так как главная часть ее массы состоит из силикатных пород, обычно представляющих собой смеси различных соединений кремния с кислородом и рядом других элементов.

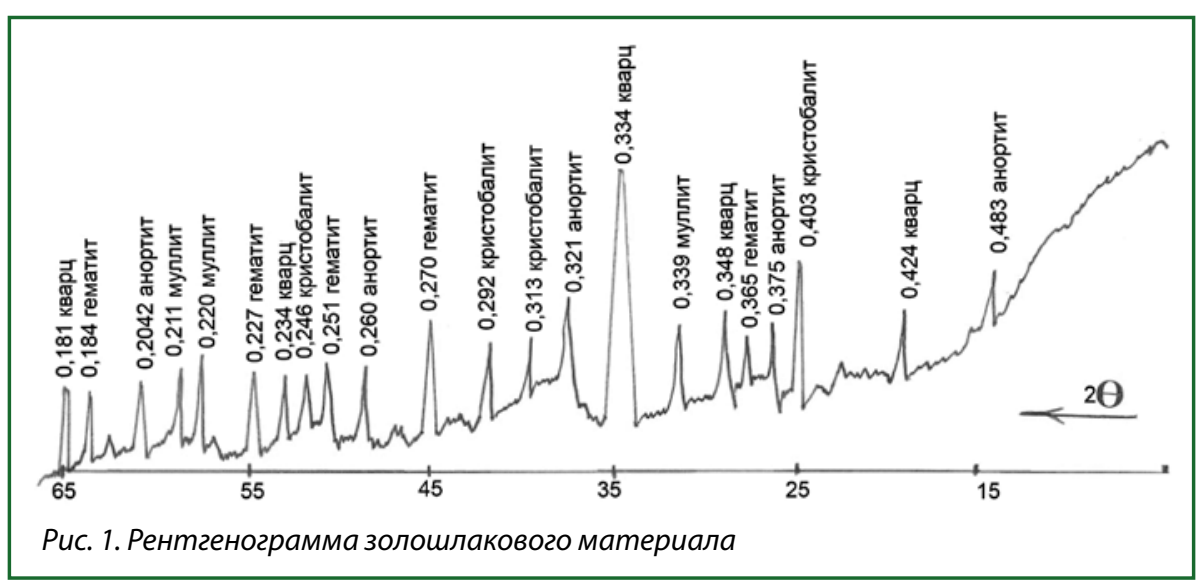




\begin{tabular}{l|c}
\multicolumn{1}{c|}{ Показатели } & Результат \\
\hline Содержание кремнезема, \% & 38,9 \\
\hline Содержание оксида натрия, \% & 10,63 \\
Силикатный модуль & 2,9 \\
Плотность, г/см ${ }^{3}$ & 1,45
\end{tabular}

A

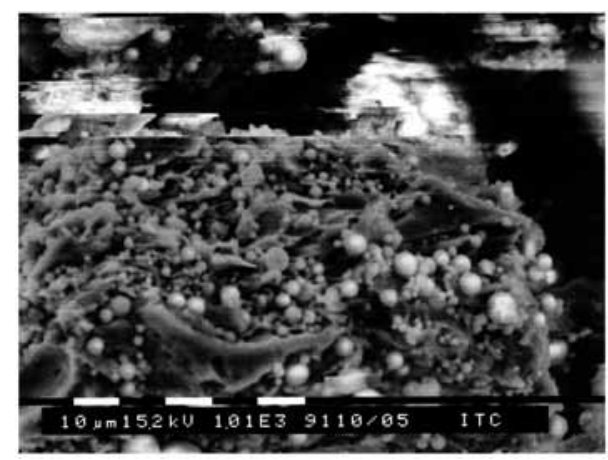

Б

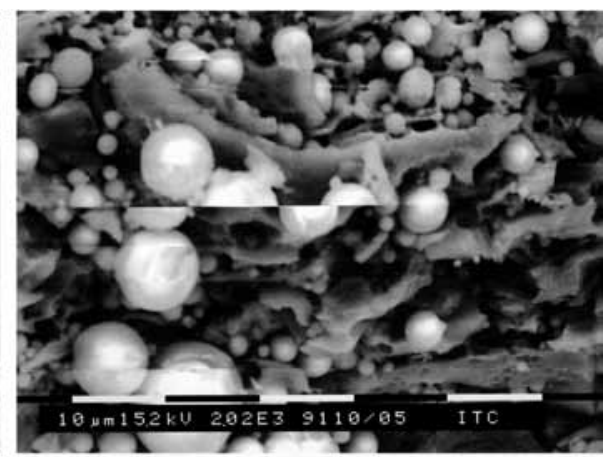

II

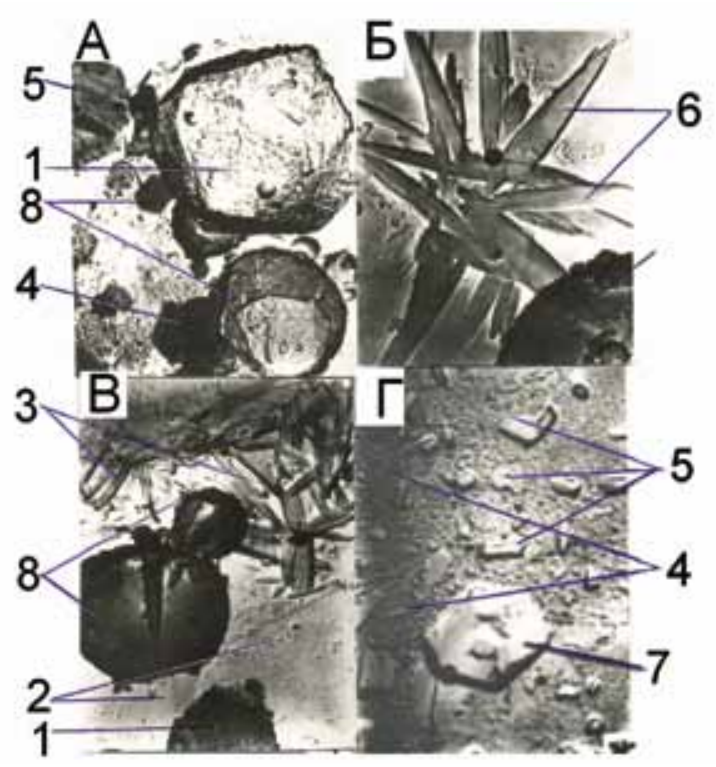

Рис. 2. Микроструктура золошлакового материала: 1 - магнетит; 2 - стекло; 3 - муллит; 4 - органические включения; 5 - квари; 6- анортит; 7- полевой шпат; 8-гематит; I -увеличение A - 500, Б- 1000; II -увеличение A и B -20000, Б и Г -24000 в раствор и движение молекул воды в фазу стекла), и коагуляция смеси приводят к повышению вязкости, что дает возможность формовать изделия различного размера.

\section{РЕЗУЛЬТАТЫ}

Керамическая композичия для изготовления легковесного кирпича. Для получения легковесного кирпича использовалась композиция, включающая межсланцевую глину и золошлаковый материал при следующем соотношении компонентов, мас. \%: межсланцевая глина - 50-70, золошлаковый материал - 30-50.

Полученные легковесные кирпичи имели следующие физико-механические показатели: плотность - 1180-1245 кг/ м³; теплопроводность 0,234$0,258 \mathrm{BT} /\left(\mathrm{M}^{\circ} \mathrm{C}\right)$, прочность кирпича соответствовала маркам более М100. Исследования показали, что при наличии теплотворной способности в сланцевой золе более 2000 ккал/кг положительный эффект (марка кирпича не менее 100, теплопроводность менее $0,25 \mathrm{Bт} /\left(\mathrm{M} \cdot{ }^{\circ} \mathrm{C}\right)$ достигается добавкой в шихту $50 \%$ золы.

\section{Композиция \\ для производства пористого заполнителя.}

В данной работе для получения пористого заполнителя на основе сланцевой золы в качестве связующего использовалось товарное жидкое стекло, модифицированное хлоридом натрия. Физико-химические показатели жидкого стекла представлены в табл. 5.

Введение в жидкое стекло хлорида натрия в количестве 1-3\% после тщательного перемешивания приводит к растворению хлористого натрия. Ионы натрия понижают силикатный модуль смеси, а ионы хлора, действуя в качестве сильного окислителя, способствуют коагуляции смеси. Понижение силикатного модуля, приводящее к снижению числа силоксановых связей (что существенно облегчает переход ионов щелочного металла
Для получения пористого заполнителя использовалась композиция, включающая натриевое жидкое стекло, хлорид натрия и золошлаковый материал при следующем соотношении, мас. \%: натриевое жидкое стекло - 50-75, хлорид натрия - 1-3, золошлаковый материал - 22-49.

Полученные пористые заполнители (керамзит) имели следующие физико-механические показатели: насыпная плотность - 135-158 кг/м³; прочность на сжатие 2,22- 2,28 МПа, коэффициент размягчения 96,4-98,5\%. Таким образом, с применением отходов производств получен теплоизоляционный материал высокого качества. 


\section{ЗАКЛЮЧЕНИЕ}

Таким образом, исследования показывают, что из-за хищнического обращения с природой в настоящее время в ней обнаружились существенные негативные, часто необратимые, сдвиги, поэтому человечеству следует понять, что под действием антропогенных факторов природная ситуация катастрофически быстро меняется в худшую сторону. В настоящее время действующая система экологического регулирования в России оторвалась от реального контекста, в котором должна существовать. Значительная часть извлекаемых природных ресурсов в России используется нерационально. Одним из наиболее перспективных направлений по использованию отходов производств является вовлечение их во вторичный оборот в качестве вторичных материальных или энергетических ресурсов. За счет вовлечения промышленных отходов в производство теплоизоляционных материалов возможно кардинально изменить параметры сырьевой базы России, что будет способствовать также снижению экологической напряженности в регионах. Использование отходов топливно-энергетического комплекса: межсланцевой глины и сланцевой золы в производстве теплоизоляционных материалов способствует: утилизации промышленных отходов; охране окружающей среды; расширению сырьевой базы для получения керамических строительных материалов. Утилизация промышленных отходов способствует развитию «зеленой» экономики.

\section{Список литературы}

1. Абдрахимов В.3. Вопросы экологии и утилизации техногенных отложений в производстве керамических композиционных материалов. Самара: Самарская академия государственного и муниципального управления, 2010. $160 \mathrm{c}$.

2. Абдрахимов В.3. Экологические и технологические принципы использования золошлакового материала и карбонатного шлама для производства высокомарочного кирпича в Самарской области. Самара: Самарский государственный архитектурно-строительный университет, 2009. 164 с.

3. Абдрахимов В.3. Концепция современного естествознания. Самара: Самарский государственный экономический университет, 2015. 340 с.

4. Юридические абсурды в правовом поле и методология их устранения на примере природоохранного законодательства / Ю.Л. Максименко, И.Д. Горкина, 3.А. Кучкаров и др. // Экология и промышленность России. 2017. T. 21. № 3. С. 36-40.

5. Абдрахимова Е.С., Абдрахимов В.3., Кайракбаев А.К. Инновационные направления по использованию отходов топливно-энергетического комплекса в производстве теплоизоляционных материалов. Актобе: Казахско-Русский международный университет, 2015. 276 с.

6. Кайракбаев А.К., Абдрахимов В.3., Абдрахимова Е.С. Исследование регрессивным методом зависимости отходов топливно-энергетической промышленности на сушильные свойства стеновой керамики // Экология промышленного производства. 2015. № 1. С. 6-10.
7. Абдрахимов В.З., Абдрахимова Е.С. Экологические и практические аспекты использования шлака от сжигания угля в производстве керамических материалов на основе межсланцевой глины // Уголь. 2014. № 4. С. 41-43. URL: http://www.ugolinfo.ru/Free/042014.pdf (дата обращения: 15.09.2017).

8. Абдрахимова Е.С., Абдрахимов В.З. Влияние отходов углеобогащения на пористость теплоизоляционных материалов на основе межсланцевой глины // Техника и технология силикатов. 2016. № 1. С. 24-30.

9. Абдрахимов В.3., Абдрахимова Е.С., Абдрахимова И.Д. Исследование теплопроводности легковесных материалов из отходов топливно-энергетической промышленности без применения природных традиционных материалов // Уголь. 2016. № 4. С. 72-75. doi: 10.18796/0041-5790-2016-4-72-75. URL: http:// www.ugolinfo.ru/Free/042016.pdf (дата обращения: 15.09.2017).

10. Абдрахимова Е.С., Кайракбаев А.К., Абдрахимов В.3. Использование золошлакового материала в производстве теплоизоляционных материалов на основе межсланцевой глины // Уголь. 2016. № 10. С 74-78. doi: 10.18796/0041-5790-2016-10-74-78. URL: http:// www.ugolinfo.ru/Free/102016.pdf (дата обращения: 15.09.2017).

11. Абдрахимова Е.С., Кайракбаев А.К., Абдрахимов В.3. Использование отходов углеобогащения в производстве керамических материалов - современные приоритеты развития для «зеленой» экономики // Уголь. 2017. № 2. C. 54-57. DOI: 10.18796/0041-5790-2017-2-54-57.

12. Абдрахимов В.3., Абдрахимова Е.С., Абдрахимова И.Д. Получение теплоизоляционного материала на основе жидкого стекла и отходов углепереработки, образующихся при обогащении коксующихся углей // Уголь. 2017. № 4. C. 64-67. DOI: 10.18796/0041-5790-2017-4-64-67.

13. Абдрахимов В.З., Абдрахимова Е.С., Кайракбаев А.К. Использование отходов золоторудного месторождения, нефтехимии и энергетики в производстве керамических материалов - перспективное направление для «зеленой» экономики // Экология и промышленность России. 2015. № 5. С. 37-41.

14. Абдрахимов В.З., Лобачев Д.А., Абдрахимова Е.С. Проблемы экологического образования не способствуют развитию «зеленой» экономики // Экология и промышленность России. 2016. Т. 20. № 11. С. 54-58.

15. Абдрахимов В.3., Абдрахимова Е.С. Инновационные направления по использованию бурового шлама в производстве керамических материалов на основе межсланцевой глины - перспективное направление для «зеленой» экономики // Экология и промышленность России. 2017. Т. 21. № 13. С. 26-31.

16. Абдрахимов В.3., Абдрахимова Е.С., Кайракбаев А.К. Использование отходов топливно-энергетического комплекса в производстве теплоизоляционных материалов на основе жидкостекольных композиций. Актобе: Казахско-Русский международный университет, 2016. $140 \mathrm{c}$.

17. Абдрахимова Е.С., Абдрахимов В.З. Высокопористый теплоизоляционный материал на основежидкого стекла // Физика и химия стекла. 2017. Т. 43. № 2. С. 222-230. 
UDC 666.691:669.86.002.3 @ V.Z. Abdrakhimov, 2018

\section{Title}

ENVIRONMENTAL SYSTEM DAMAGE MITIGATION DUE TO INTERSCHISTIC CLAY AND BOTTOM-ASH MATERIAL APPLICATION IN LIGHTWEIGHT BRICK AND POROUS AGGREGATE PRODUCTION

DOI: http://dx.doi.org/10.18796/0041-5790-2018-10-77-83

\section{Authors}

Abdrakhimov V.Z.

2 Samara State University of Economics, Samara, 443090, Russian Federation

\section{Authors' Information}

Abdrakhimov V.Z., Doctor of Engineering Sciences, Professor, tel.: +7 (846) 337-58-92, e-mail: 3375892@mail.ru

\section{Abstract}

It is shown that currently in Russia has formed the environmentally unbalanced investment policies, which leads to increased imbalances between prirodoekspluatirujushchie and processing, manufacturing and infrastructure sectors of the economy largely due to the deficit of environmental factors in macroeconomic policy, which leads to further environmental degradation and depletion of natural resources. Therefore, an important feature of the new model must be founded on environmental sustainability. One of the most promising areas for the use of waste production is involving them recycled as secondary material or energy resources. Due to the involvement of industrial waste in manufacturing of heat-insulating materials may dramatically change the parameters of the raw material base of Russia, which also contributes to reducing environmental impact in the regions. The use of waste fuel and ENERGY complex: inter-shale clay and ash material in the production of insulation products contributes to: a) recycling of industria waste; $b$ ) the protection of the environment; $b$ ) expansion of raw materials base for production of ceramic building materials. Utilization of industria wastes contributes to the development of "green" economy. Under the green economy in this paper refers to the production of various types of cleaning equipment, utilization of secondary resources and waste, provision of environmental services, etc.

\section{Keywords}

Environmental protection, Waste management, Inter-shale clay bottom ash material, Lightweight bricks, Porous filler.

\section{References}

1. Abdrakhimov V.Z.. Voprosy ekologii i utilizatsii tekhnogennyh otlozhenij v proizvodstve keramicheskih kompozitsionnyh materialov [Environmental issues and man-made deposits disposal in ceramic composite materials production]. Samara, Samara Academy of State and Municipal Management Publ., 2010, $160 \mathrm{p}$.

2. Abdrakhimov V.Z. Ehkologicheskie i tekhnologicheskie printsipy ispol'zovaniya zoloshlakovogo materiala i karbonatnogo shlama dlya proizvodstva vysokoma rochnogo kirpicha $v$ Samarskoy oblasti [Environmental and process concepts of bottom-ash materials application for high grade bricks production in Samara region]. Samara, Samara State University of Architecture and civil Engineering Publ., 2009, 164 p.

3. Abdrakhimov V.Z. Kontseptsiya sovremennogo estestvoznaniya [Modern natural science concept] Samara, Samara State University of Economics Publ., $2015,340 p$

4. Maksimenko Yu.L., Gorkina I.D., Kuchkarov Z.A., et al. Yuridicheskie absurdy v pravovom pole i metodologiya ih ustraneniya na primere prirodoohrannogo zakonodatel'stva [Judicial absurdity within legal framework and methods of elimination with reference to the environmental legislation]. Ekologiyaipromysh lennost' Rossii - Environment and Industry in Russia, 2017, Vol. 21, no. 3, pp. 36-40. 5. Abdrakhimova E.S., Abdrakhimov V.Z. \& Kairakbaev A.K. Innovatsionnye napravleniya po ispol'zovaniyu othodov toplivno-ehnergeticheskogo kompleksa v proizvodstve teploizolyatsionnyh materialov [Innovative trends of fuel-energy complex wastes application in thermal insulation materials production]. Aqtobe, Kazakh-Russian International University Publ., 2015, 276 p.

6. Kairakbaev A.K., Abdrakhimov V.Z. \& Abdrakhimova E.S. Issledovanie regressivnym metodom zavisimosti othodov toplivno-ehnergeticheskoy promyshlennosti na sushil'nye svoystva stenovoy keramiki [Fuel-energy industry wastes influence on the wall tiles drying properties investigation by regression method]. Ekologiya promyshlennogo proizvodstva-Commercial ProductionEcology, 2015, no. 1, pp. 6-10. 7. Abdrakhimov V.Z. \& Abdrakhimova E.S. Ekologicheskie i prakticheskie as pekty ispol'zovaniya shlaka ot szhiganiya uglya v proizvodstve keramicheskih materialov na osnove mezhslantsevoy gliny [Ecological and practical aspects of coal slag use in production of interschistic clay-based ceramics]. Ugol' Russian Coal Journal, 2014, no. 4, pp. 41-43. Available at: http://www.ugolinfo. ru/Free/042014.pdf (accessed 15.09.2017).

8. Abdrakhimov V.Z. \& Abdrakhimova E.S. Vliyanie othodov ugleobogashcheniya na poristost' teploizolyatsionnyh materialov na osnove mezhslantsevoy gliny [Coal preparation wastes effect on interschistic clay based thermal insulation materials porosity]. Tekhnika i tekhnologiya silikatov - Silicates Technical and Process Aspects, 2016, no. 1, pp. 24-30.

9. AbdrakhimovV.Z., Abdrakhimova E.S. \& Abdrakhimova I.D. Issledovanie teploprovodnosti legkovesnyh materialov iz othodov toplivno-ehnergeticheskoy promyshlennosti bez primeneniya prirodnyh traditsionnyh materialov [Investigation of thermal conductivity of lightweight materials from energy industry wastes without the use of natural traditional materials]. Ugol' - Russian Coal Journal, 2016, no. 4, pp. 72-75. doi: 10.18796/0041-5790-2016-4-72-75. Available at: http://www.ugolinfo.ru/Free/042016.pdf (accessed 15.09.2017).

10. Abdrakhimova E.S., Kairakbaev A.K. \& Abdrakhimov V.Z. Ispol'zovanie zoloshlakovogo materiala $v$ proizvodstve teploizolyatsionnyh materialov na osnove mezhslantsevoy gliny [Bottom-ash material application in interschistic clay - based thermal insulation materials production]. Ugol' - Russian Coal Journal, 2016, no. 10, pp. 74-78. doi: 10.18796/0041-5790-2016-10-74-78. Available at: http://www.ugolinfo.ru/Free/102016.pdf (accessed 15.09.2017). 11. Abdrakhimova E.S., Kairakbaev A.K. \& Abdrakhimov V.Z. Ispol'zovanie othodov ugleobogashcheniya $v$ proizvodstve keramicheskih materialov sovremennye prioritety razvitiya dlya "zelenoy" ehkonomiki [Coal concentration wastes utilization in ceramic materials production - present-day priorities for environment friendly economics development]. Ugol' - Russian Coal Journal, 2017, no. 2, pp. 54-57. doi: 10.18796/0041-5790-2017-2-54-57.

12. Abdrakhimov V.Z., Abdrakhimova E.S. \& Abdrakhimova I.D. Poluchenie teploizolyatsionnogo materiala na osnove zhidkogo stekla i othodov uglepererabotki, obrazuyushchihsya pri obogashchenii koksuyushchih ugley [Soluble glass and carbonizing coal preparation processing wastes based thermal insulation materials production]. Ugol' - Russian Coal Journal, 2017, no. 4, pp. 64-67. doi: 10.18796/0041-5790-2017-4-64-67.

13. Abdrakhimov V.Z., Abdrakhimova E.S. \& Kairakbaev A.K. Ispol'zovanie othodov zolotorudnogo mestorozhdeniya, neftekhimii i ehnergetiki v proizvodstve keramicheskih materialov perspektivnoe napravlenie dlya "zelenoy" ehkonomiki [Gold deposits, petrochemical and power industry wastes utilization in ceramic materials production as a high-potential trend for environment - friendly economics]. Ekologiya i promyshlennost'Rossii-Environment and Industry in Russia, 2015, no. 5, pp. 37-41.

14. Abdrakhimov V.Z., Lobachev D.A. \& Abdrakhimova E.S. Problemy ehkologicheskogo obrazovaniya ne sposobstvuyut razvitiyu"zelenoy" ehkonomiki [Environmental education problems do not stimulate environmental friendly economics development]. Ekologiya ipromyshlennost'Rossii-Environment and Industry in Russia, 2016, Vol. 20, no. 11, pp. 54-58.

15. Abdrakhimov V.Z., Abdrakhimova E.S. Innovatsionnye napravleniya po ispol'zovaniyu burovogo shlama v proizvodstve keramicheskih materialov na osnove mezhslantsevoy gliny - perspektivnoe napravlenie dlya "zelenoy" ehkonomiki [Innovative trend of drilling slurry utilization in interschistic clay based ceramic materials production as a high-potential trend for environment-friendly economics]. Ekologiya i promyshlennost' Rossii - Environment and Industry in Russia, 2017, Vol. 21, no. 13, pp. 26-31.

16. Abdrakhimova E.S., Abdrakhimov V.Z.\&Kairakbaev A.K. Ispol'zovanie othodov toplivno-ehnergeticheskogo kompleksa v proizvodstve teploizolyacionnyh materialov na osnove zhidkostekol'ny hompozicij [Fuel and energy complex wastes utilization in soluble glass based thermal insulation materials production]. Aqtobe, Kazakh- Russian International University Publ., 2016, 140 p. 17. Abdrakhimova E.S. \& Abdrakhimov V.Z. Vysokoporistyy teploizolyatsionnyy material na osnove zhidkogo stekla [Soluble glass based highly porous material]. Fizika i himiya stekla - Glass Physics and Chemistry, 2017, Vol. 43, no. 2, pp. 222-230. 


\section{Хабаровский край и СУЭК определили направления совместной работы}

\section{по социально-экономическому развитию региона}

12 сентября 2018 г. в рамках Восточного экономического форума Вячеслав Шnорт, на тот период губернатор, председатель Правительства Хабаровского края и Владимир Рашевский, генеральный директор АО «СУЭК» подписали Соглашение о сотрудничестве между Правительством Хабаровского края и АО «СУЭК».

В подписанном документе зафиксированы направления взаимодействия руководства региона и компании в области реализации государственных программ Хабаровского края, развития социальной среды, планов социального развития центров экономического роста края, различных направлений укрепления экономического и промышленного потенциала региона.

Со стороны СУЭК, в частности зафиксированы проект развития перегрузочных мощностей АО «Дальтрансуголь» с увеличением мощности перевалки до более чем 40 млн т в год и реализация комплексного проекта развития угледобычи и углеобогащения $\mathrm{AO}$ «Ургалуголь» с доведением объема добычи энергетического угля до 10 млн т и изучением возможности доведения объемов добычи до 15 млн т. Компания обязуется при планировании и реализации инвестиционных проектов обеспечивать внедрение и использование наилучших доступных технологий в области охраны окружающей среды. В соглашении также отмечены направления деятельности СУЭК, нацеленные

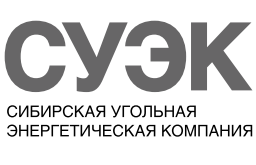

на повышение уровня жизни населения Хабаровского края, укрепление социальной стабильности в регионе.

Правительство Хабаровского края будет предпринимать меры по дальнейшему развитию благоприятных инвестиционных условий в регионе, инициировать совершенствование нормативной базы и содействовать развитию железнодорожной инфраструктуры на территории Хабаровского края.

Вячеслав Шnорm отметил на церемонии подписания: «Крупные инвестиционные проекты компания реализует в одной из точек Хабаровского края - это порт Ванино. Это миллиардные инвестиции, и для нас очень важно, чтобы эта компания участвовала в наших сочиальных проектах. Это основная суть соглашения. Соглашение уже в работе. Мы небудем раскачиваться завтра-послезавтра. Оно уже в работе, мы просто закрепили сегодня юридически наши взаимоотношения».

Владимир Рашевский подчеркнул: «Соглашение, которое мы подписали, определяет порядок взаимодействия администрации Хабаровского края и компании «СУЭК» в связи стеми инвестиционными проектами, которые компания планирует реализовывать в ближайшие пять лет. Мы активно работаем в Хабаровском крае, видим большой потенциал экономики региона и видим потенциал улучшения жизни людей».

\section{СУЭК стала победителем конкурса «МедиаТЭК» сразу в двух номинациях}

ВМоскве объявленырезультатывсероссийского конкурса «МедиаТЭК-2018» Министерстваэнергетики Российской Федерации. По решению авторитетного экспертного совета $\mathrm{AO}$ «Cибирская угольная энергетическая компания» (СУЭК) признана победителем сразу в двух номинациях. Комплексный проект, посвященный празднованию в 2017 г. 70-летия Дня шахтера, стал первым в номинации «Популяризация профессий ТЭК», а рассказывающая о деятельности СУЭКгазета «События и люди» признана лучшим корпоративным СМИ.

Всероссийский конкурс «МедиаТЭК» проводится с 2015 г. Министерством энергетики Российской Федерации. Основная цель конкурса - стимулирование роста профес- сионализма энергетических компаний в области информационного освещения своей деятельности, донесения информации до населения о проектах развития ТЭК, стимулирование проектов, связанных с популяризацией профессий топливно-энергетического комплекса и повышением значимости роли труда энергетиков, нефтяников, газовиков. Экспертный совет «МедиаТЭК» возглавляет Дмитрий Песков, пресс-секретарь Президента России, заместитель Руководителя Администрации Президента России. В состав Экспертного совета входят руководители крупнейших федеральных деловых СМИ, факультетов журналистики российских высших учебных заведений, представители органов государственной власти, эксперты в области ТЭК. 


\title{
На «Восточно-Бейском разрезе» Введены в строй новые очистные сооружения
}

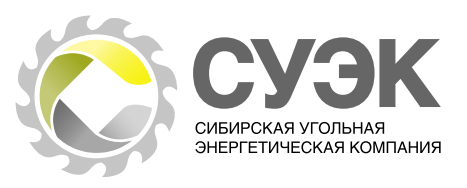

\begin{abstract}
28 августа 2018 г. на тот период глава Республики Хакасия - председатель Правительства Республики Хакасия Виктор Зимин и генеральный директор АО «Сибирская угольная энергетическая компания» Владимир Рашевский побывали на «Восточно-Бейском разрезе» (Хакасия). Руководители приняли участие в торжественном пуске сооружений, предназначенных для очистки карьерных вод.
\end{abstract}

«Мы доложили Президенту, что будем открывать здесь очистные сооружения. Сказали -сделали, - отметил глава Республики Хакасия - председатель Правительства Республики Хакасия Виктор Зимин. - Я сегодня благодарю компанию СУЭК, собственников, партнеров и коллектив, который своим трудом создал этот замечательный комплекс. Очист-

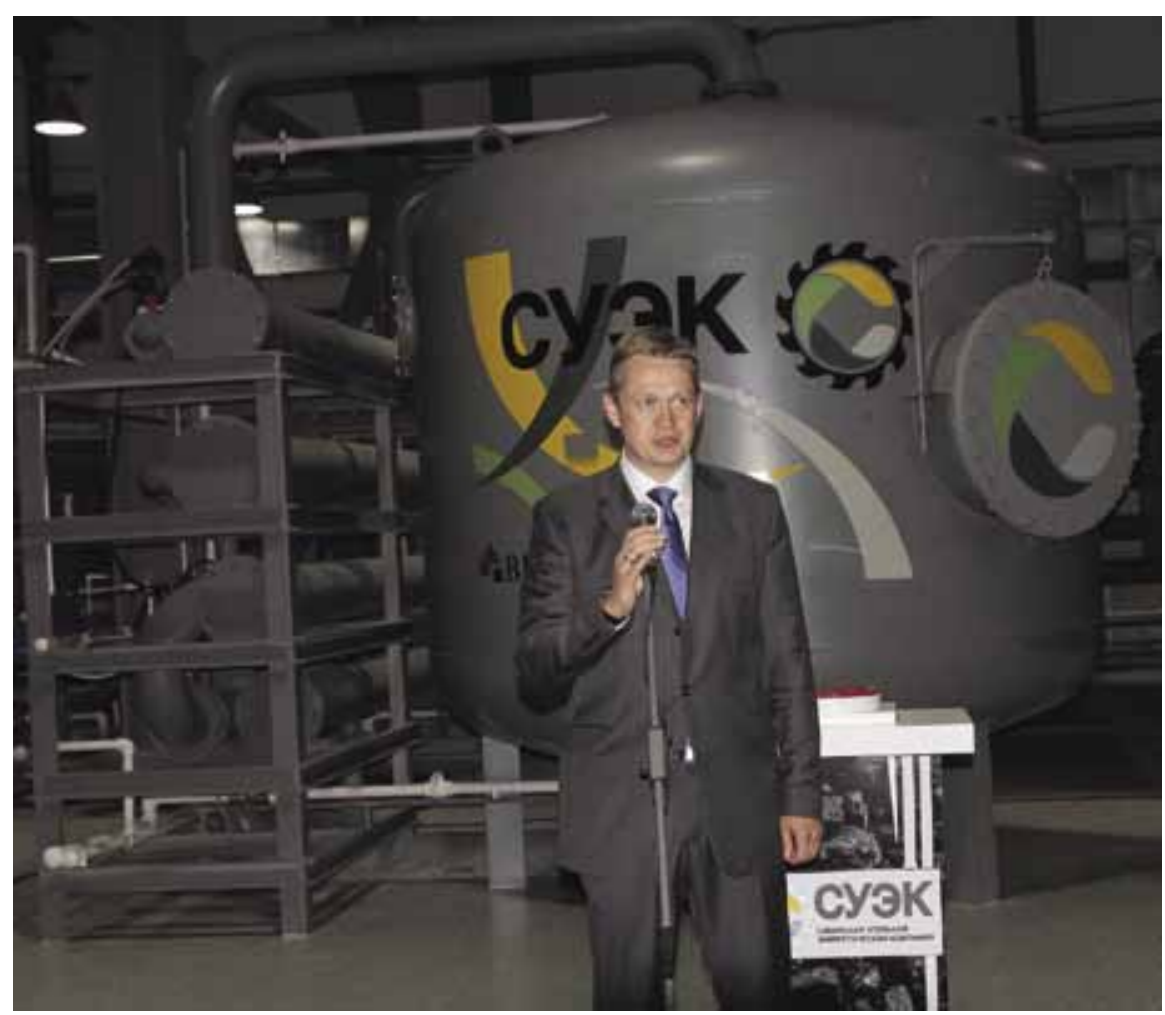

ные сооружения сродни перинатальному чентру - чистота, порядок. Спасибо, что вы вкладываете в нашу землю».

Специалисты Восточно-Бейского разреза подробно рассказали о технологии работы сооружений. Вода, извлеченная при добыче угля из карьера, по системе трубопроводов будет поставляться на очистные сооружения. В соответствии с проектом мощность очистных сооружений составляет $350 \mathrm{~m}^{3} / 4$ с перспективой увеличения до $670 \mathrm{~m}^{3} / 4$, связанного с планами Восточно-Бейского разреза на дальнейший рост угледобычи.

Задача очистных сооружений, в которые СУЭК инвестировала порядка 200 млн руб., - вернуть карьерной воде первоначальное качество, чтобы она точно соответствовала составу воды подземных горизонтов. Для этого извлеченная из карьера вода пройдет двухступенчатую систему очистки через установки фильтрации АКВАФЛОУ. Специальные датчики автоматически будут контролировать эффективность очистки, извещать оператора о соответствии работы очистных установленным параметрам. На заключительном этапе очищенная вода пройдет обеззараживание в установке с ультрафиолетовым излучением и через поле инфильтрации вернется вновь в подземные горизонты.

\section{СУЭК консолидирует СГК}

$\mathrm{AO}$ «СУЭК» консолидирует ООО «СГК» в рамках осуществляемой реструктуризации группы. Данная мера позволит повысить операционную и финансовую эффективность консолидированной компании, даст большую гибкость в реагировании на изменения рыночной конъюнктуры и при решении стратегических задач.

Интеграция положительно повлияет на дальнейшее увеличение надежности в обеспечении потребителей доступной электро- и теплоэнергией, поможет эффективнее реализовывать значимые инвестиционные проекты как в угольной, так и в энергетической отраслях.

«Консолидация угольных и энергетических активов усиливает позиции СУЭК как одной из крупнейших энергоугольных компаний мира, а увеличившийся масштаб и ди- версификация бизнеса расширяют СУЭКдоступ крынкам капиталов», - отмечает генеральный директор $\mathrm{AO}$ «СУЭК» Владимир Рашевский.

Наша справка.

AO «Сибирская угольная энергетическая компания» (СУЭК) - одна из ведущих угледобывающих компаний мира, крупнейший в России производитель угля, крупнейший поставщик угля на внутренний рынок и наэкспорт, один из ведущих производителей тепла и электроэнергии в $\mathrm{Cu}$ бири.Добывающие, перерабатывающие, энергетические, транспортные и сервисные предприятия СУЭК расположены в 11 регионах России. На предприятиях СУЭК работают более 66000 человек. Основной акционер - Андрей Мельниченко. 


\section{Холдинговая компания «СДС-Уголь» стала партнером Фонда «Сколково»}

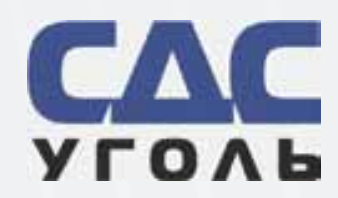

\begin{abstract}
В рамках Восточного экономического форума Фонд «Сколково» и АО ХК «СДСУголь» 11 сентября 2018 г. подписали соглашение о сотрудничестве. Подписи под документом поставили старший вице-президент по инновациям Фонда "Сколково» Кирилл Каем и генеральный директор АО ХК «СДС-Уголь» Геннадий Алексеев.

В соответствии с соглашением АО ХK «СДС-Уголь» обязуется в ближайшее время создать на территории «Сколково» партнерский центр для ведения совместной исследовательской деятельности. Конкретные объемы финансовых обязательств сторон будут определены отдельными договорами, заключенными в ходе исполнения соглашения.
\end{abstract}

Сотрудничество между сторонами будет осуществляться по ряду направлений, в том числе по проектам в области стратегического развития предприятий угледобывающего холдинга, технологий в области управления качеством отгружаемой продукции и приобретаемого оборудования, исследований в области создания инновационных продуктов и повышения эффективности деятельности производственных и транспортных предприятий, а также цифровизации угольной промышленности, применения современных технологий и комплексных решений в производстве и ряда других.

«Объем добычи предприятиями «СДС-Уголь» по итогам прошлого года составил более 27 млн т угля. При этом у холдинга есть потенциал увеличения объемов до 40 млн т к 2025 г. и до 50 млн т к 2035 г. Только непрерывные улучшения всех технологических прочессов и использование передовых инновачионных технологий позволят холдингу «СДС-Уголь» успешно реализовать стратегию перспективного развития. Уверены, что наше партнерство с Фондом «СКолково» станет не просто продуктивным, но и будет иметь синергетический эффрект", - отметил Геннадий Алексеев, генеральный директор АО ХК «СДС-Уголь».

"Создание партнерского чентта сократит путь инновационных разработок до их внедрения в компании. Надо отметить, что «СДС-Уголь» ориентирован на такуюработу, компания применяет самые передовые разработки. И мы рассчитываем, что в ближайшем будущем мы еще дальше продвинемся в этом направлении», - подчеркнул Кирилл Каем, старший вице-президент по инновациям Фонда «Сколково».

\section{Наша справка.}

АОХК «СДС-Уголь» основано в 2006 г. иявляется отраслевым холдингом АО ХК «Сибирский Деловой Союз». Сегодня в составе угольного холдинга: четыре разреза, две шахты, четыре обогатительные фабрики и ряд сервисных предприятий, расположенных на территории Кемеровской области с общей численностью сотрудников около 9 тыс. человек. 3 а 12 лет работы на рынке компания вышла на третье место в России по объемам добычи угля и входит в тройку крупнейших российских экспортеров угольной продукции.

Фонд "Сколково»- некоммерческая организачия, созданная по инициативе Президента России в сентябре 2010 г. Цель Фонда - создание экосистемы, благоприятной для развития предпринимательства и исследований в областях: энергоэффективность и энергосбережение, ядерные, космические, биомедичинские, стратегические компьютерные технологии и программное обеспечение. $\mathrm{Ha}$ Фонд возложены функции управления Инновачионным иентром «Сколково», деятельность которого регулируется специальным законом, предоставляющим особые экономические условия стартапам, прошедшим специальную внешнюю технологическую экспертизу (сейчас их более 1800). В 2017 г. выручка компаний-участников «Сколково» составила 79 млрд руб., совокупная выручка за 8 лет существования проекта достигла 250 млрд руб. В стартапах работают около 30 тыс. человек, из них более 5 тыс. - на территории «Сколково». Запатентовано более 1300 разработок и технологических решений. Важной частьюэкосистемы "Сколково» является исследовательский университет - Сколковский институт науки и технологий (Сколтех), созданный и функционирующий при поддержке Массачусетского технологического института. Cтроительство инфраструктуры ИЦ “Сколково» за счет федерального бюджета завершено (построены Технопарк, Университет, Гимназия, дорожная и инженерная инфраструктуры). Введено в эксплуатацию около 500 тыс. кв.м. В ближайшие 3 года эта иифра удвоится. Сайт: www.sk.ru 


\section{Руководители СУЭК заняли верхние строчки рейтинга российских менеджеров}

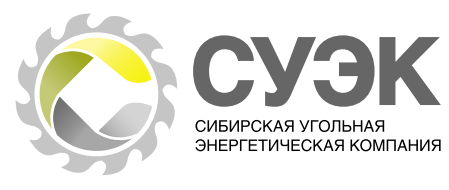

Так, генеральный директор АО «СУЭК» Владимир Рашевский занимает первое место в рейтинге высших руководителей. Высшие позиции также занимают Сергей Григорьев среди директоров по отношениям с органами власти, Игорь Грибановский среди коммерческих директоров, Денис Илатовский среди директоров по логистике, Александр Редькин среди директоров по правовым вопросам. Также в число лучших руководителей страны входят Владимир Тузов (директора по маркетингу), Сергей Твердохлеб (директора по корпоратив- ному управлению), Дмитрий Сыромятников (директора по персоналу).

Основной акционер АО «СУЭК» Андрей Мельниченко находится в рейтинге в числе бизнес-лидеров страны.

«Топ-1000 российских менеджеров»- единственное в стране исследование работы российских управленцев, выявляющее лидеров в отраслях и по направлениям. Рейтинг формируется Ассоциацией менеджеров при консультационной поддержке ИД «Коммерсантъ» и верифицируется членами Академии премии «Топ-1000».

\section{Участники трудового отряда СУЭК}

\section{приняли участие в работе дискуссионных клубов Евразийского форума в Санкт-Петербурге}

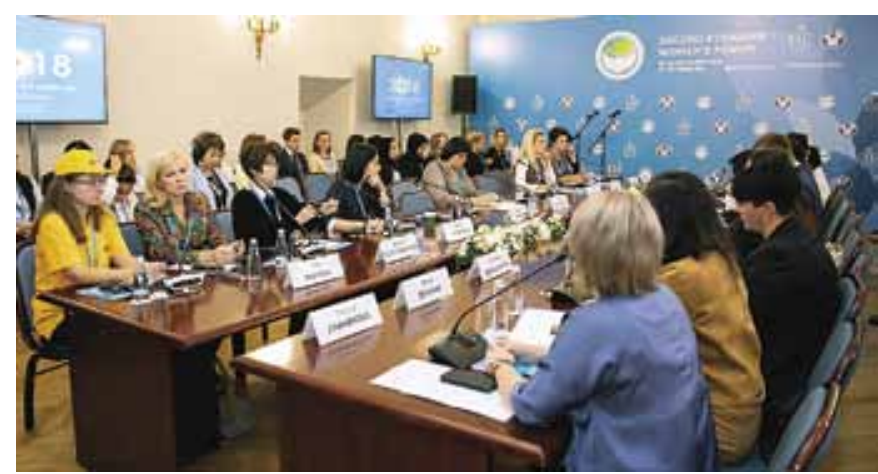

Ребята из трудового отряда СУЭК совместно с генеральным директором Фонда развития моногородов Ириной Макиевой приняли участие в работе двух международных дискуссионных клубов второго Евразийского форума в Санкт -Петербурге.

«Позитивная энергия молодых» - тема одной из открытых дискуссий форума, где выступала генеральным директор Фонда развития моногородов. Здесь были обсуждены такие вопросы, как механизмы поддержки и продвижения идей молодыхженщин и девочек, а также институты наставничества в женском сообществе, индивидуальные практики. В заседании международного дискуссионного клуба «Женщины - губернаторы - стратегия эффективности и развития территорий» Ирина Макиева рассказала о своем опыте комплексного решения социально-экономических задач, в том числе задачи создания дополнительных возможностей для самореализации женщин в российских моногородах. В современной глобальной экономике города конкурируют между собой за талантливых людей. Чем комфортнее и интереснее жизнь в городе, тем большим центром притяжения он является. Поэтому важно не про- сто инвестировать в создание новых производств, но и заниматься формированием комфортной городской среды, способствовать развитию малого и среднего бизнеса, в том числе социально ориентированного предпринимательства. Особое внимание в работе по развитию моногородов, по мнению Ирины Макиевой, необходимо уделять молодёжи: «Наша молодежь очень активна и, что особенно важно, умеет быстро адаптироваться к изменениям. Именно молодые люди являются носителями новых навыков, создателями новых профессий. Именно им придется принимать решения о жизни городов, регионов и стран уже завтра. Чем раньше мы начнем вовлекать подростков и молодых людей в общественную жизнь, тем эффективней сможем развивать экономикунашихтерриторий».

Вместе с Ириной Макиевой в работе форума приняла участие участник трудового отряда СУЭК, ученица гимназии №18 Ленинск-Кузнецкого городского округа (Кемеровская обл.) Кристина Кузнецова. Она рассказала о том, чего не хватает на территории города для развития и досуга современной молодежи.

В июне 2018 г. в рамках Молодежного форума «Кузбасс № 1» состоялось подписание Соглашения между Департаментом молодежной политики и спорта Администрации Кемеровской области и Фондом «СУЭК - РЕГИОНАМ» о сотрудничестве и совместной деятельности по созданию и финансированию подростковых трудовых отрядов в летний период. В кузбасский отряд СУЭК вошли более 1,2 тыс. подростков в возрасте от 14 до 18 лет. Основной фронт работы - благоустройство и озеленение городов и поселков, адресная помощь ветеранам труда и пожилым людям. Молодые кузбассовцы работали на пяти территориях - в Ленинске-Кузнецком, Киселевске, в Полысаево, а также в Прокопьевском и Ленинск-Кузнецком районах. 


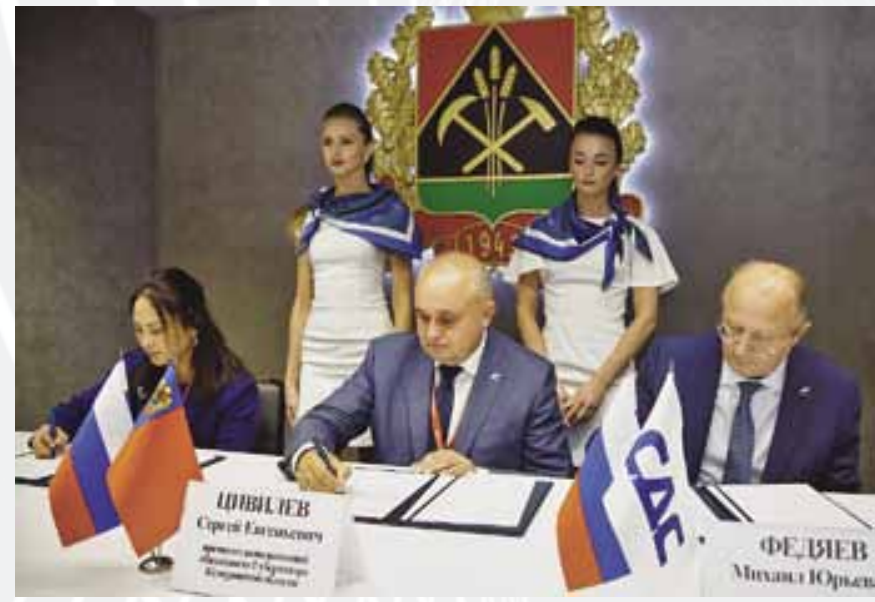

На полях Восточного экономического форума Коллегия Администрации Кемеровской области, китайская компания Beijing CATIC Industry Limited и AO «Холдинговая компания «Сибирский Деловой Союз» 12 сентября 2018 2. подписали Меморандум о взаимном сотрудничестве в изучении проектов на территории Кемеровской области. Свою подпись под документом поставили врио губернатора Кемеровской области Сергей Цивилев, президент компании Beijing CATIC Industry Limited г-жа Сюй Тао и президент АО ХК «СДС» Михаил Федяев.

Взаимодействие российской и китайской компаний, а также кузбасских властей будет строиться на принципах партнерства и консолидации усилий в решении задач социального и экономического развития Кемеровской области, социальной ответственности по обеспечению достойных условий труда и быта для населения региона, а также на принципах взаимной заинтересованности и информационной открытости, отмечается в документе.

Согласно Меморандуму, ХК «СДС» намерена повышать эффективность производственной деятельности предприятий, входящих в холдинг, применять наилучшие доступные технологии и оборудование для добычи угля и углеобогащения, направленные на рост производительности, безопасности технологических процессов и снижение негативного воздействия на окружающую среду от производственной деятельности.

Beijing CATIC Industry Limited (КНР, дочернее предприятие AVIC International Holding Corporation), в соответствии с Меморандумом рассмотрит возможность участия в реализации проектов, направленных на комплексное развитие угольной промышленности Кемеровской области, повышение эффективности кузбасских предприятий по добыче и обогащению угля, а также ориентированных на социально-экономическое развитие региона в целом. Кроме того, китайская компания рассмотрит возможность создания на территории Кемеровской области собственного сервисного центра, соответствующий наилучшим мировым стандартам, и консигнационных складов в целях обеспечения высокоэффективного сервисного обслуживания эксплуатируемого оборудования Beijing CATIC Industry Limited на предприятиях региона.

Коллегия Администрации Кемеровской области намеревается в установленном законодательством порядке оказывать всестороннее содействие в изучении реализуемых проектов, обеспечивать доступность сведений о потенциальной возможности и условиях эксплуатации природных и промышленных ресурсов Кемеровской области, при необходимости - организовывать координационные совещания с участием заинтересованных сторон.

По словам Сергея Цивилева, он хорошо знает деятельность Beijing CATIC Industry Limited, и благодаря тому, что китайский партнер начнет свою деятельность в Кузбассе в сотрудничестве с такой надежной компанией, как ХК «СДС», в кратчайшие сроки будет достигнут положительный результат: «Это будет полезно как для нашего региона, так и для Сибирского Делового Союза.

Как отметил Михаил Федяев, ХК «СДС» уже ведет переговоры с компанией и планирует в следующем году приобрести экскаваторы китайского производства. Также холдинг намерен сотрудничать с китайской стороной при реализации проектов по строительству новых предприятий.

Г-жа Сюй Тао в свою очередь выразила уверенность в том, что сотрудничество ХК «СДС» с ее компанией при поддержке местных властей позволит повысить эффективность предприятий холдинга.

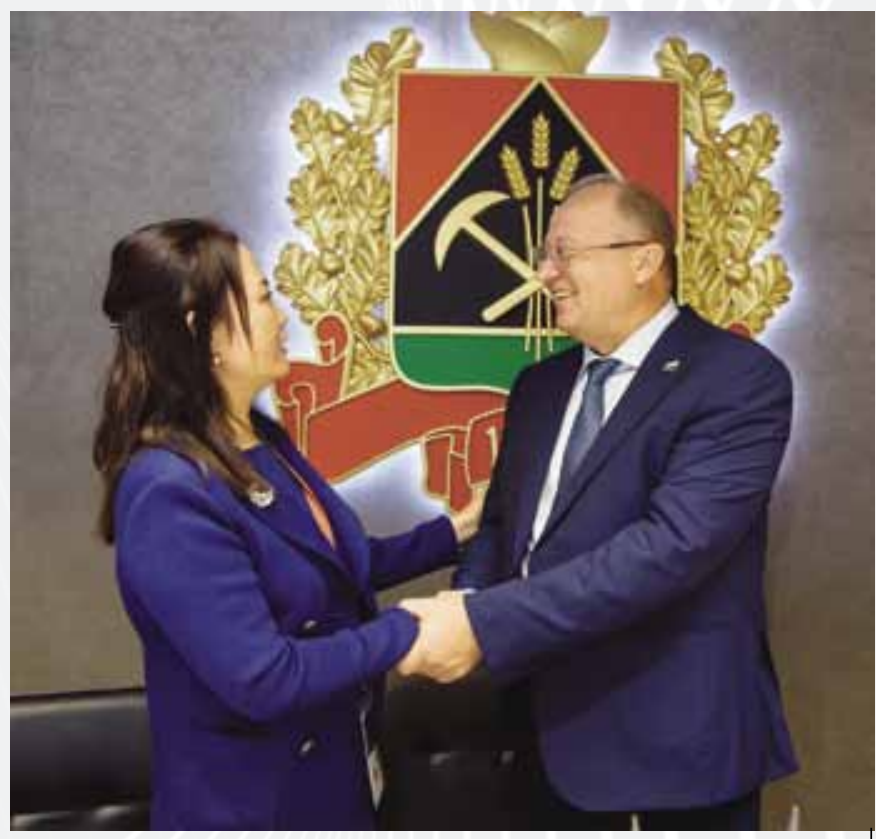




\section{Повышение ценности руководимого -}

\section{главная задача руководителя}

DOI: http://dx.doi.org/10.18796/0041-5790-2018-10-90-92

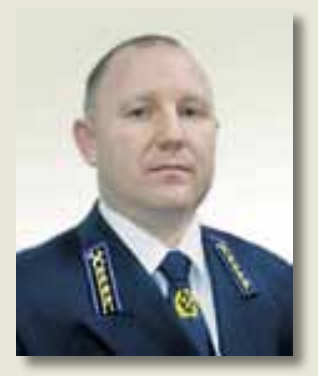

ЖУНДА Сергей Валерьевич

Заместитель генерального

директора по ПК, ПБ, ОТ и Э

АО «Разрез Тугнуйский»,

671353, n. Саган-Нур,

Республика Бурятия, Россия,

e-mail:zhundasv@suek.ru

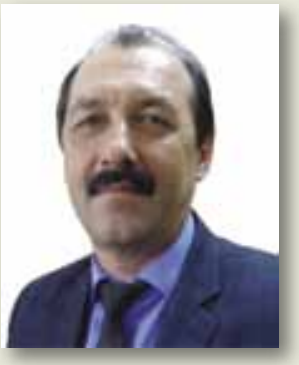

\section{СТЕПАШКИН}

Александр Леонидович

Начальник службы

теплоэнергоснабжения

АО «Разрез Тугнуйский»,

671353, n. Саган-Нур,

Республика Бурятия, Россия,

e-mail: stepashkinal@suek.ru

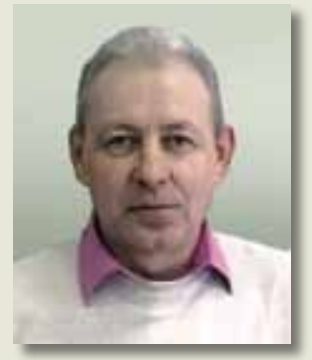

\section{ДОВЖЕНОК Александр Сергеевич}

Доктор техн. наук,

главный научный сотрудник

Челябинского филиала ИГД УрО РАН, 454048, г. Челябинск, Россия,

тел.: +7 (351) 216-17-92,

e-mail:dovgenok@bk.ru

В статье на примере службы теплоэнергоснабжения AO «Разрез Тугнуйский» представлен опыт вовлечения персонала в процесс повышения его квалификации посредством разработки и освоения стандартов трудовых процессов. Такой путь повышения ценности персонала прост, не требует дополнительных финансовых затрат и применим в текущей производственной деятельности.

Ключевые слова: руководитель, персонал участка, повышение квалификации, качество трудовых процессов, разработка и освоение стандартов.

\section{ВВЕДЕНИЕ}

По мере развития общества и экономики на угледобывающих предприятиях растут требования к персоналу в исполнении своих трудовых функций. Одним из путей достижения требуемой квалификации в этих условиях являются разработка и освоение стандартов трудовых процессов, качество которых обеспечивает необходимый уровень эффективности и безопасности производства [1].

\section{ОПЫТ РАЗРАБОТКИ СТАНДАРТОВ ТРУДОВЫХ ПРОЦЕССОВ}

В целях повышения эффективности и безопасности производства в АО «Разрез Тугнуйский» перед всеми руководителями участков и служб была поставлена задача разработки и освоения стандартов трудовых процессов [2].

Наибольший интерес представляет опыт организации разработки и освоения стандартов производственных процессов, имеющийся в службе теплоэнергоснабжения. Основные особенности полученного опыта:

$>$ отношение начальника службы к стандарту как к личному управленческому инструменту, необходимому для повышения качества своей деятельности, трудовых процессов и квалификации персонала. Такое отношение означает, что он лично заинтересован в высоком качестве этого инструмента и делает для этого все необходимое;

$>$ начальник службы формируету мастера потребность в разработке и применении стандартов трудовых процессов как личного инструмента мастера, используемого для управления коллективом.

Формирование потребности осуществляется посредством совместной оценки фактической деятельности мастера, анализа успешных и неуспешных его решений производственных задач [3, 4]. Мастер, понимающий необходимость разработки стандартов, может спокойно, настойчиво и гибко взаимодействовать с рабочими по разработке их личных стандартов:

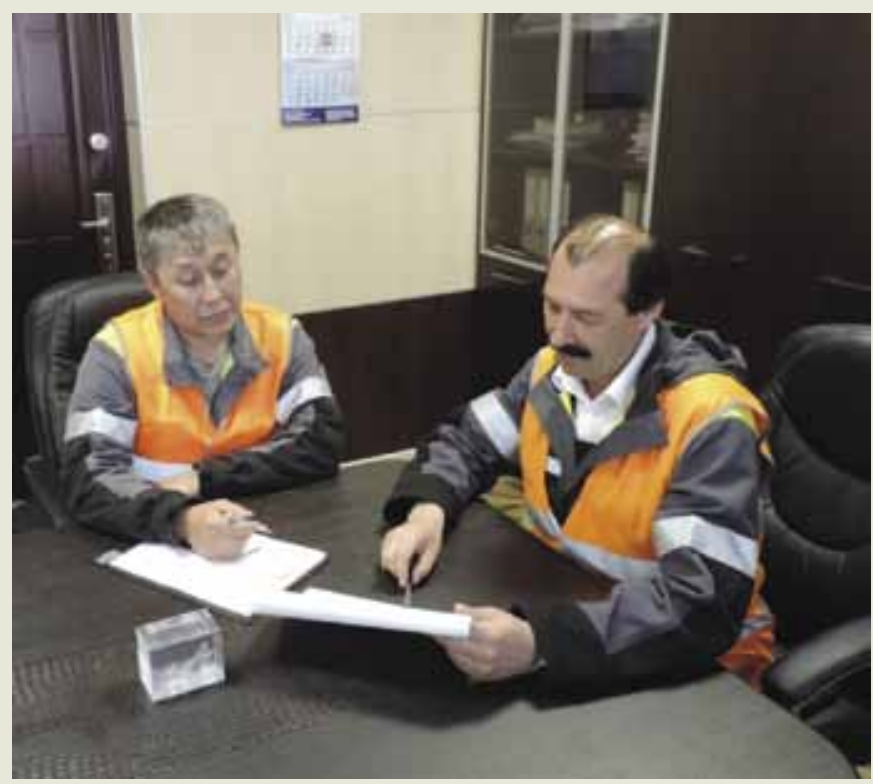

Руководитель службы с мастером прорабатывают стандарт трудового прочесса 

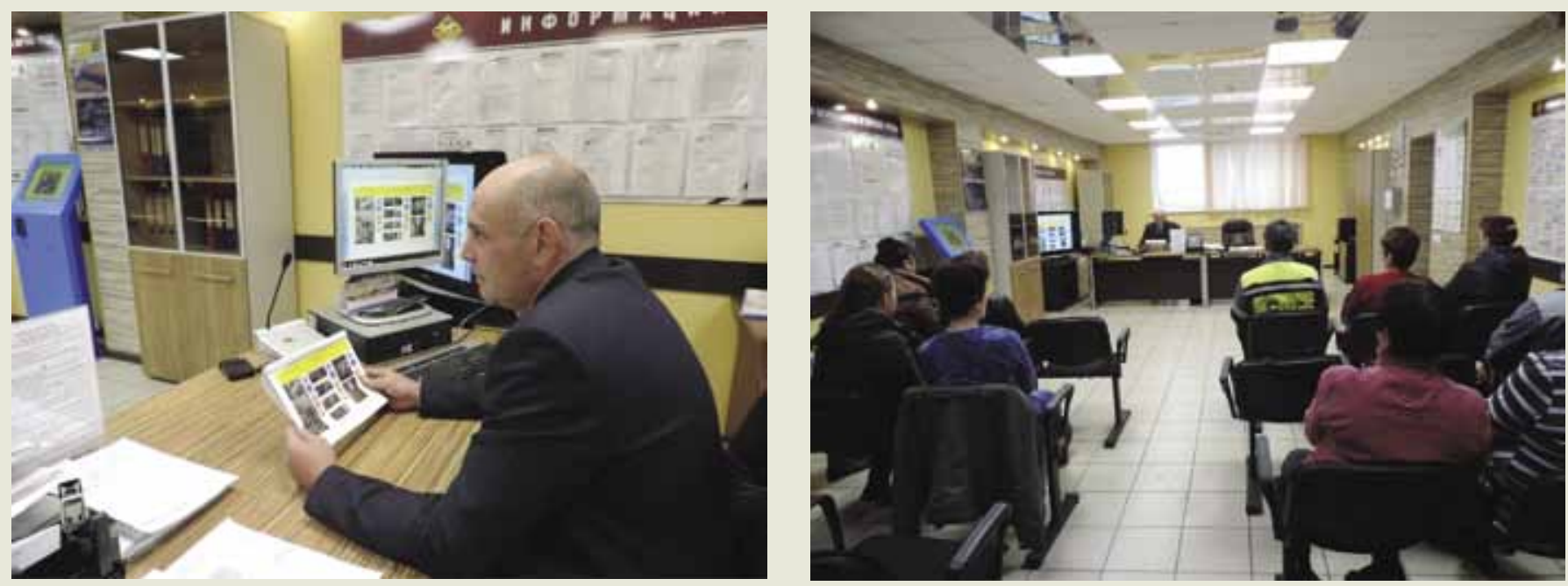

Мастер с рабочими на наряде прорабатывают стандарт трудового прочесса

> мастер разрабатывает стандарт, облегчающий, упрощающий и впоследствии, повышающий качество его работы. Поэтому он с охотой находит на это время в период решения текущих задач и ежедневно на совещаниях по планированию производства обсуждает с начальником службы результаты, возникающие затруднения и способы их решения. Таким образом, во время производственного совещания уделяется внимание развитию, находится возможность развивать нематериальный актив - стандарты производства и тем самым развивать неосязаемый актив - профессионализм персонала;

$>$ разработка стандартов мастером осуществляется с периодическим вовлечением в этот процесс рабочих. Вовлечение является важным средством повышения ценности как работников, так и стандартов, реально облегчающих труд исполнителей. Это усиливает их мотивацию к освоению и применению стандартов, обеспечивает рост личной квалификации и общий успех в подразделении [5];

$>$ начальник службы:

- осуществляет контроль за ходом и результатами разработки стандартов при ежедневном планировании производства для обеспечения непрерывности движения к результату. Это позволяет в течение 1-2 недель получить рабочий вариант стандарта трудового процесса, который примерно за такое же время дорабатывается до применения;

- информирует работников о разработке и освоении стандартов при выдаче нарядов на смену. Критерием освоенности является отсутствие отклонений от стандарта;

- ставит задачу мастерам и рабочим применять стандарты, регулярно контролирует исполнение стандартов сам, а также через мастеров:

- поясняет работнику, если он нарушил стандарт, в чем заключается нарушение и к чему оно приводит или может привести;

- выясняет, при повторном нарушении, почему происходят отклонения в применении стандарта;

- делает предупреждение лично и на наряде при следующем нарушении, если оно не обосновано или произошло по неисполнительности работника;

- следующий этап - наказывает неисполнительных.

Опыт разработки и освоения стандартов в службе теплоэнергоснабжения $\mathrm{AO}$ «Разрез Тугнуйский» показал, что вовлечение персонала в этот процесс является эффективным способом повышения профессионализма персонала, а значит, ценности каждого работника. Тем самым руководитель подразделения формирует мотивацию и квалификацию персонала своего подразделения в соответствии со своими требованиями.

\section{ЗАКЛЮЧЕНИЕ}

Участие персонала в разработке стандартов трудовых процессов - эффективный путь его вовлечения в процесс повышения эффективности и безопасности производства, а тем самым повышения его профессионализма. Опыт службы теплоэнергоснабжения AO «Разрез Тугнуйский» может быть успешно применен на любом производственном участке.

\section{Список литературы}

1. Роль руководителя и персонала в обеспечении безопасности производства / В.Б. Артемьев, В.В. Лисовский, А.И. Добровольский и др. Отдельная статья Горного информационно-аналитического бюллетеня. М.: Горная книга, 2017. 48 с. (Сер. «Б-ка горного инженераруководителя». Вып. 32).

2. Подход к повышению безопасности труда посредством стандартизации процессов и операций ремонта карьерных автосамосвалов, опыт ОАО «Разрез Тугнуйский» / В.Н. Кулецкий, А.И. Каинов, А.В. Горохов, П.П. Яньков, А.В. Галкин // Уголь. 2013. № 7. С. 46-49. URL: http://www.ugolinfo.ru/Free/072013.pdf (дата обращения: 15.09.2018).

3. Опыт успешного руководства. Отдельная статья Горного информационно-аналитического бюллетеня. М.: Горная книга, 2013. 64 с.

4. Опыт руководства AO «Разрез Тугнуйский». Отдельная статья Горного информационно-аналитического бюллетеня. 2017. № 10. (Специальный выпуск № 33). М.: Горная книга. 2017.88 с. (Сер. «Б-ка горного инженера-руководителя». Вып. 33).

5. Надежное обеспечение безопасности труда на предприятиях СУЭК / В.Б. Артемьев, В.В. Лисовский, Е.П. Ютяев и др. Отдельная статья Горного информационноаналитического бюллетеня. М.: Горная книга, 2018. 42 с. (Сер. «Б-ка горного инженера-руководителя». Вып. 34). 
UDC 658.386-052.2:622.33(571.52):658.516 @ S.V. Zhunda, A.L. Stepashkin, A.S. Dovgenok, 2018

ISSN 0041-5790 (Print) • ISSN 2412-8333 (Online) • Ugol' - Russian Coal Journal, 2018, № 10, Pp. 90-92

\section{Title}

\section{ENHANCING THE VALUE OF A SUPERVISED EMPLOYEE IS THE KEY TASK OF A MANAGER}

DOI: http://dx.doi.org/10.18796/0041-5790-2018-10-90-92

\section{Authors}

Zhunda S.V. ', Stepashkin A.L. ${ }^{,}$, Dovgenok A.S. ${ }^{2}$

1 "Tugnuysky open-pit mine" JSC, Sagan-Nur village, Republic of Buryatia, 671353, Russian Federation

${ }^{2}$ Chelyabinsk Branch of Institute of Mining of Ural Branch of RAS, Chelyabinsk, 454048, Russian Federation

\section{Authors' Information}

Zhunda S.V., Deputy General Director, e-mail: zhundasv@suek.ru

Stepashkin A.L., Chief of service heat and power supply,

e-mail: stepashkinal@suek.ru

Dovgenok A.S., Doctor of Engineering Sciences, Chief Researcher, tel.: +7 (351)

216-17-92, e-mail: dovgenok@bk.ru

\section{Abstract}

The paper, using the example of "Tugnuysky open-pit mine"JSC heat and power supply service, presents the experience of involving personnel in professional development activities through establishing and mastering work process standards. This way of enhancing the personnel value is simple, does not require additional financial costs and is applicable in the ongoing production flow.

\section{Keywords}

Manager, Site personnel, Professional development, Work process quality, Establishing and mastering of standards

\section{References}

1. Artemiev V.B., Dobrovolskiy A.I., Lisovskiy V.V. et al. Rol' rukovoditelya i personala $v$ obespechenii bezopasnosti proizvodstva. Otdel'naya stat'ya [Management and personnel role in production safety. Separate article]. Gornyy Informatsionno-Analiticheskiy Byulleten'-Mining Information-AnalyticalBulletin,
2017, Issue 32, 48 p. (Seriya "B-ka gornogo inzhenera-rukovoditelya - "Mining engineer - manager's library" series).

2. Kuletsky V.N., Kainov A.I., Gorokhov A.V., Jankov P.P. \& Galkin A.V. Podkhod k povysheniyu bezopasnosti truda posredstvom standartizatsii protsessov i operatsiy remonta kar'ernykh avtosamosvalov: opyt OAO "Razrez Tugnuyskiy" [Strategy of labour safety improvement using the standardization of procedures and operations of open-pit dump trucks: experience of "Tugnuysky" open-pit mine]. Ugol' - Russian Coal Journal, 2013, No. 7, Pp. 46-49. Available at: http:// www.ugolinfo.ru/Free/702013.pdf (accessed 15.09.2018).

3. Opyt uspeshnogo rukovodstva [Successful leadership experience]. Individual article in Gornyy Informacionno-Analiticheskiy Byulleten - Mining InformationAnalytical Bulletin. Moscow, Gornaya Kniga Publ., 2013, 64 p.

4.Opyt rukovodstva AO RazrezTugnujskij ["Tugnuysky open-pit mine"JSC management experience]. Individual article in Gornyy Informacionno-Analiticheskiy Byulleten - Mining Information-Analytical Bulletin, 2017. No. 10. (special issue No. 33). Moscow, Gornaya Kniga Publ., 2017, 88 p. (Series “Mining EngineerManager's Library", issue 33).

5. Artemiev V.B., Lisovskiy V.V., Yutyaev E.P. et al. Nadezhnoe obespechenie bezopasnosti truda na predpriyatiyakh SUEK [Ensuring reliable labor safety in SUEK enterprises]. Individual article in Gornyy Informacionno-Analiticheskiy Byulleten - Mining Information-Analytical Bulletin, Moscow, Gornaya Kniga Publ., 2018, 42 p. (Series "Mining Engineer-Manager's Library", issue 34).

\section{Бездымное топливо СУЭК презентовали на Международном форуме «Технопром» в Новосибирске}

Разработка «интеллектуальных» технологий, их форсированное внедрение во все отрасли жизни - в Новосибирске в последние дни лета прошел Международный форум технологического развития «Технопром». О важности события не только для научного сообщества, но и в глобальном смысле - для выхода России на новые интеллектуальные и технологические рубежи, стимулирования научно-технического прогресса, укрепления союза науки и производства, науки и бизнеса - свидетельствует визит на форум главы государства.

«По сути, от передовыхтехнологий, ихэффективной разработки и быстрого, что самоеглавное, внедрениязависит жизнеспособность челых обществ и государств, позиции стран в мире, особенно таких крупных, как Россия. Потому научно-технологический прорыв мы поставили в число ключевых национальных челей и приоритетов. И убежден, мы способны его совершить, объединяя усилия государства, бизнеса, научно-образовательного сообщества, расширяя свободудля инициативы и творчества наших людей», - сказал Президент России Владимир Путин.

Активнымучастником форума стало АО «СУЭК-Красноярск»: на выставке угольщики представили бездымный топливный брикет, произведенный на Березовском разрезе в Красноярском крае. Инновационный продукт - результат совместной работы с наукой и тот важнейший катализатор, который может и должен дать импульс для выхода угольной отрасли на качественно новый уровень, заставить уголь «заиграть» новыми гранями, заявить о себе как о многофункци- ональном, эффективном, экологичном сырье. Недаром многие эксперты сходятся во мнении, что альтернатив углю по объемам запасов, доступности, как в плане добычи, так и стоимости, практически нет, и основной вопрос - в технологиях его сжигания. Основное преимущество бездымного топлива СУЭК состоит как раз в том, что при сжигании оно дает тепла в два раза больше, чем исходный продукт - бурый уголь, и в то же время не образует дыма и вредных летучих веществ - они удаляются из брикета еще на стадии производства. В феврале т.г. инновационный продукт уже был представлен Владимиру Путину во время визита в Красноярск, где он инспектировал объекты Всемирной зимней универсиады-2019. Особое внимание в ходе встреч с руководством края и крупнейших компаний, представленных в регионе, глава государства уделил экологической обстановке. Он высоко оценил разработку СУЭК, рассказал о которой генеральный директор компании Владимир Рашевский, и поручил Правительству региона и угольщикам объединить усилия, чтобы максимально заменить в городе традиционные виды топлива более экологичным бездымным брикетом.

Чтобы полностью обеспечить частный сектор и малые котельные эффективным и экологичным топливом, сегодня на Березовском разрезе строят производственный комплекс, рассчитанный на объемы в 30 тыс. т готовой продукции в год с последующим увеличением мощностей до 60 тыс. т. Ввести его в эксплуатацию планируется уже в этом году. Инвестиции СУЭК в проект превышают полмиллиарда рублей. 
Выпуск 1. Уголь. Основные показатели и ориентиры реализации программы развития угольной промышленности на период до 2030 года

\section{Добыча угля}
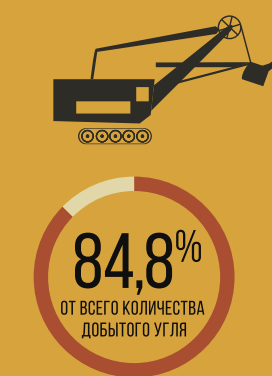

СИБИРСКИЙ ФО лидер по добыче угля в России

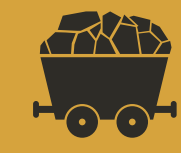

86

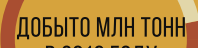

В 2016 ГОДУ

322,9

ДОБЫЧА УГЛЯ

Коксующийся $(101,7 \%]$

- Энергетический $(107,2 \%)$
Динамика поставок угольной продукции, млн тонн

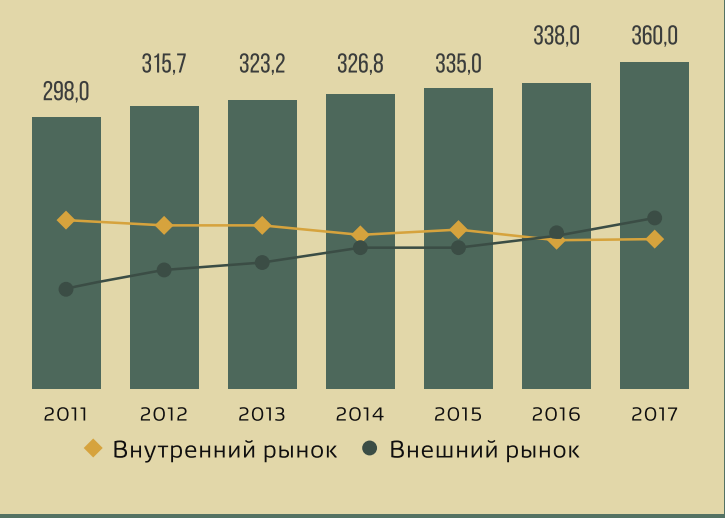

Динамика инвестиций угольной продукции, млн тонн

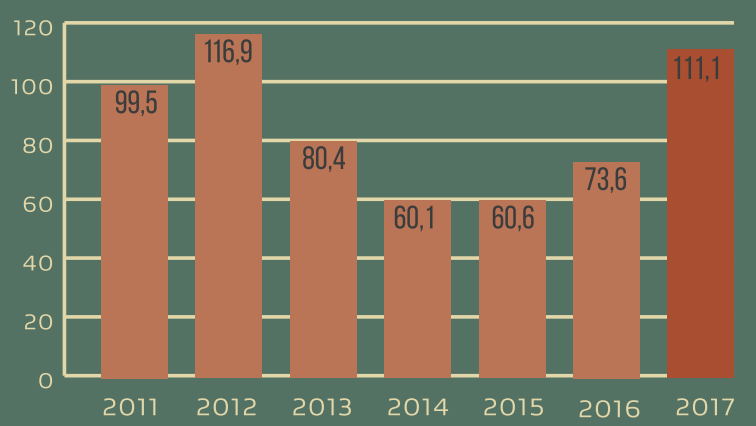

На территории РФ добычу угля осуществляют:

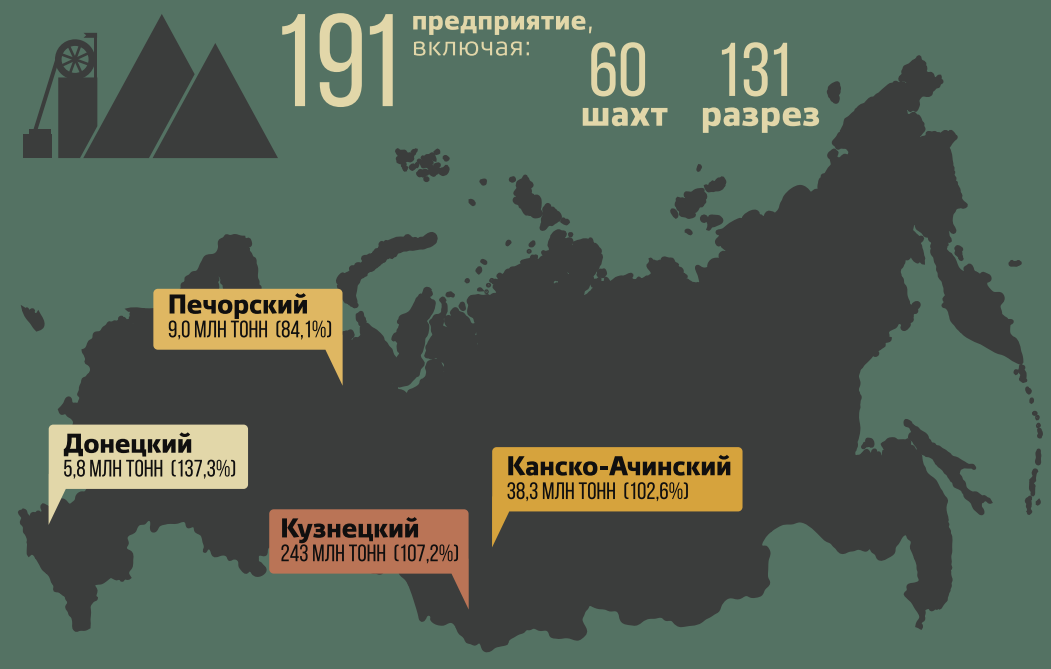

А Распределение объемов добычи угля в 2017 году по основным бассейнам

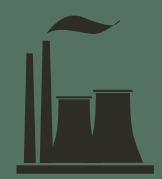

В 2017 году на обогатительных фабриках и установках переработано 191,5 млн тонн рядового угля (101,3\%), В т.ч. энергетических углей $-110,1$ млн тонн $(104,4 \%)$, коксующихся $-81,4$ млн тонн $(98,4 \%)$

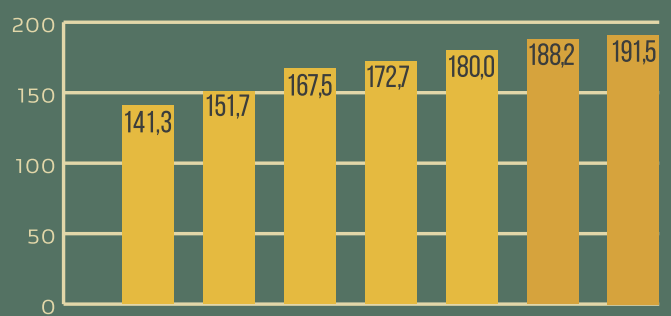

А Динамика объемов переработки угля млн тонн

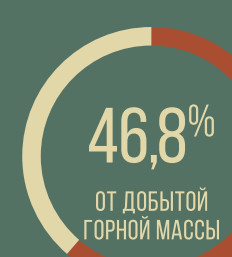

уровень обогащения угля (48,8\% в 2016 году)

\section{Перспективы}

Программа развития угольной промышленности России до 2030 года включает в себя меры по усовершенствованию данных показателей. Для решения этих целей необходим комплексный подход, включающий в себя взаимодействие бизнеса с органами государственной власти, финансовыми структурами и инвесторами.

Одним из ключевых мероприятий, проводимых на территории России, на котором ведущими компаниями отрасли, деятелями науки и представителями государственных структур подробно обсуждаются актуальные вопросы угольной промышленности, является международная промышленная выставка-форум «МАЙНИНГ И МЕТАЛЛУРГИЯ 2019», которая пройдет 25-27 сентября 2019 года в МВК "Новосибирск Экспоцентр".

http://miningmetall.com

$+7 / 495 / 108-18-69$

EXPO@MININGMETALL.COM

$\mathbf{f} \boldsymbol{*}$ • MININGMETALL

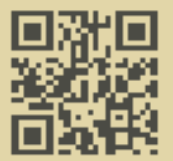




\section{Инновационные методы рекультивации отвалов угледобывающих предприятий в криоаридных условиях Средней Сибири}

DOI: http://dx.doi.org/10.18796/0041-5790-2018-10-94-97

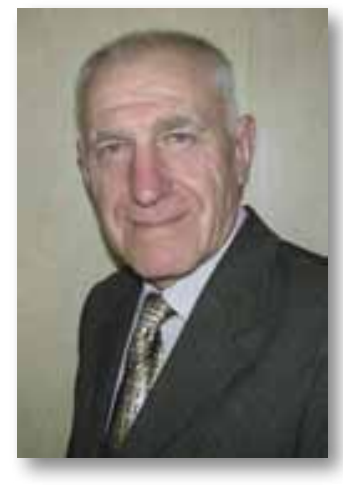

\section{ЛАВРИНЕНКО}

Алексей Тимофеевич

Заведующий группой

рекультивачии земель

ФГБНУНаучно-исследовательский

институт аграрных проблем

Хакасии,

655132, с. Зеленое, Республика

Хакасия,

тел.: +7 (39032) 2-56-09,

e-mail:aleks233@yandex.ru

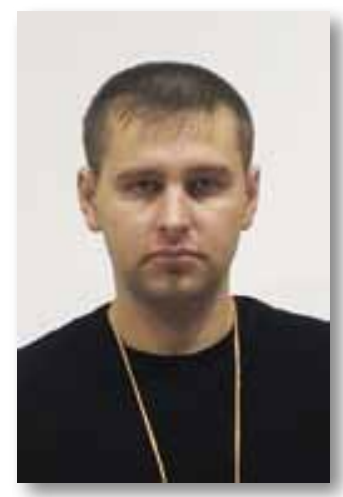

\section{МОРШНЕВ}

\section{Евгений Александрович}

Инженер-исследователь группы

рекультивачии земель

ФГБНУНаучно-исследовательский

институт аграрных проблем

Хакасии,

6550132, с. Зеленое, Республика

Хакасия,

тел.: +7 (39032) 2-56-09,

e-mail:morshnev86@mail.ru
Статья освещает проблематику рекультивации техногенно нарушенных земель с точки зрения мотивации угледобывающих предприятий к применению новых, региональных, эффективных методов восстановления нарушенных земель в специфических криоаридных условияхюга Средней Сибири. Предлагаются инновационные методы в решении задач технической и биологической рекультивации, основанные на использовании регионального ГОСТа с кратким описанием проектных решений. Аргументируется весь комплекс мероприятий по рекультивации. Даются обоснования снижения издержек на восстановление разрушенных территорий при угледобыче.
Ключевые слова: рекультивация, технозем, экологически эффективные методы, отвал, плодородный слой почвы, очаги разрастания, формирование, инновачионные способы восстановления нарушенных земель, дражированные, корнеобитаемый слой.

\section{ВВЕДЕНИЕ}

Территории, разрушенные на глубину сто и более метров в результате ведения горных работ по добыче полезных ископаемых открытым способом, катастрофически изменяют экологию в регионах добычи и требуют экономически обоснованных и экологически эффективных методов и средств для рекультивации отвалов угледобывающих предприятий, особенно в криоаридных условиях Средней Сибири [1].

К сожалению, ГОСТы СССР и СТ СЭВ (Охрана природы. Почвы.), принятые в 1950-е гг., и современные постановления Правительства Российской Федерации на их основе, не учитывают геологические и климатические особенности регионов и научно обоснованные технологии развивающейся отрасли. В экстремальных условиях некоторых регионов они усугубляют глобальность экологической проблемы регионов угледобычи.

Кроме правовых и технологических проблем качественного восстановления разрушенных территорий существуют и нравственные, так как сложившиеся взаимоотношения многочисленных контролирующих органов с угледобывающими предприятиями не всегда идут на пользу населения, волею судьбы оказавшегося с ними по соседству. Это подтверждает публикация статьи на сайте английской организации Coal Action Network c призывом запретить использование российского угля на электростанциях Великобритании из-за того, что его добыча не соответствует европейским нормам сохранения биоразнообразия и местных общин коренных народов [2].

Целью нашей работы является формирование мотивации владельцев угледобывающих предприятий к применению инновационных методов восстановления нарушенных земель.

Достижение цели осуществляется нравственной, экономической и экологической ориентацией всей цепочки управления бизнесом с помощью инновационных технологий на примере ООО «СУЭК-Хакасия». 


\section{ОПЕРЕЖАЮЩИЕ НАУЧНЫЕ ИССЛЕДОВАНИЯ} РАЗВИВАЮЩЕЙСЯ УГОЛЬНОЙ ПРОМЫШЛЕННОСТИ В РЕГИОНЕ

Генеральный директор ООО «СУЭК-Хакасия» А.Б. Килин в 2007 г. заключил договор сотрудничества с ФГБУ НИИАП Хакасии на опережающие научные исследования развивающейся угольной промышленности в регионе. Научно обоснованные, инновационные технологии, созданные и опробованные на одном предприятии по лицензионным договорам с авторским надзором внедрены на всех предприятиях компании. Экономическая эффективность инноваций оказалась на два порядка больше затрат на их создание и внедрение.

Снижение затрат на восстановление разрушенных территорий при угледобыче достигнуто за счет:

- обоснованного отказа от снятия, буртования и хранения плодородного слоя почвы (ПСП), который используется в смеси с подстилающими породами для создания корнеобитаемого слоя, при их одновременном снятии, транспортировке и распределении на поверхности отвалов [3];

- снижения лимитирующего фактора по влаге путем концентрации осадков со всей поверхности отвала в очаги разрастания (впадины, понижения, борозды) [4];

- очаговой технологии биологической рекультивации, отличающейся тем, что посадку и посев проводят локаль- но во впадины поверхности, понижения или борозды на 26-50\% поверхности отвалов [5];

- формирования отвалов в процессе отсыпки вскрышных пород по заданным проектом параметрам, без выполаживания поверхности $[6,7]$.

На первом этапе формирования отвалов проводят расчет площади и выбор технологии отсыпки внешнего отвала, который в свою очередь начинается с расчета объема отвальных пород, с учетом коэффициента разрыхления, до периода начала формирования внутреннего отвала, по заданной геометрии террасированного отвала, что дает возможность определить площадь первой террасы и количество террас внешнего отвала, исходя из заданной площади террасы и высоты снизу вверх [8]. Внешний отвал спланировать так, чтобы он стал продолжением внутреннего отвала, имея при этом профиль внешнего отвала с увеличением фронта.

Материал ПСП, снятый с расчетной площади внешнего отвала, необходимо использовать для увеличения мощности корнеобитаемого слоя по периметру отвала, на ширину 12 м трехрядной лесополосы, для создания (очага) разрастания на первый ярус и последующие террасы отвала [9]. Это дает возможность начать биологическую рекультивацию в начале строительства угледобывающего предприятия, создав очаг разрастания на последующие, формируемые в процессе отработки разреза, террасы отвала.

Схема формирования внешнего и внутреннего отвалов:

1, 2, 3, 4, 5- вскрышные породы; 6-вмешаюшие аргиллиты; 7-уголь
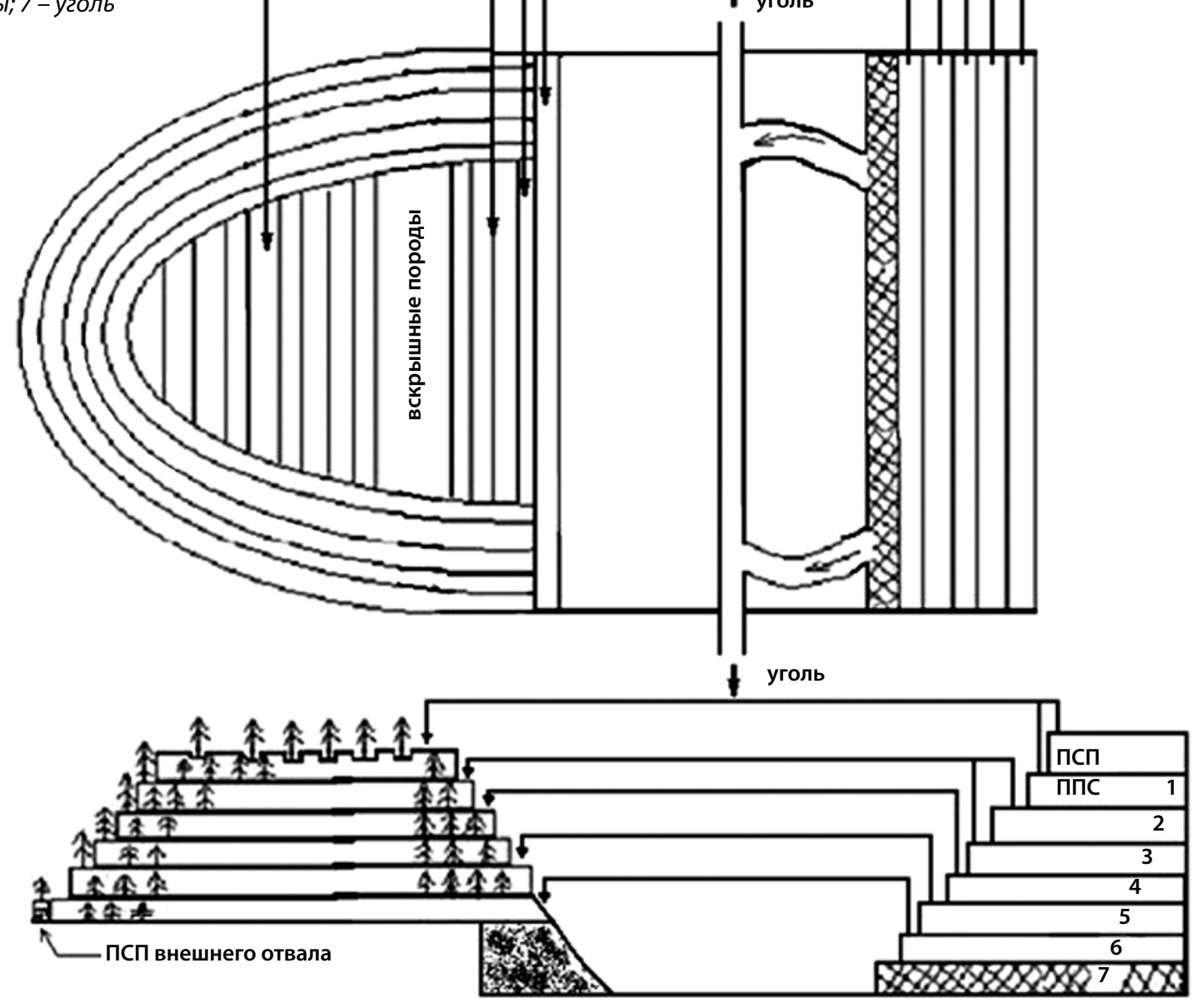
Последующие ярусы отвала отсыпают меньшей площадью с учетом площади террас и технологических дорог. На все поверхности отвала, по мере их валовой отсыпки, наносят корнеобитаемый слой гумусоаккумулятивного технозема. С этой целью первый вскрышной уступ снимают экскаватором или другими механизмами с погрузкой на транспортные средства или подачей на поверхность отвала другими способами. В процессе погрузки, разгрузки и переэкскавации вскрыши первого уступа на поверхность отвалов происходит интенсивное перемешивание верхнего плодородного слоя почвы и подстилающих пород (см. рисунок). Корнеобитаемый слой отвалов, созданный таким способом, насыщен на всю толщину органоминеральным (почвенным) комплексом [3].

В процессе биологической рекультивации посев и посадку древесно-кустарниковых пород и трав нужно проводить очагами в борозды и в понижения частично выположенных поверхностей отвала.

Расчет площади очагов разрастания на террасах отвала для посадки и посева древесно-кустарниковых пород и трав производить исходя из количества осадков. Так, при наличии осадков 270 мм в год необходимо собрать осадки со всей площади в очаги разрастания, создав на поверхности отвала впадины и понижения, площадь которых будет составлять 0,26 и 0,56 этой площади.

Посадку на вновь отсыпанных отвалах и частично спланированных площадях следует начинать после усадки и стабилизации поверхности. При рыхлом состоянии грунта отвалов (менее 20 кг/кв. см) дополнительное рыхление перед посадкой можно не проводить.

Для биологической рекультивации на горных отвалах использовали в качестве посадочного материала саженцы или сеянцы, выращенные в посевном отделении питомника (постоянная специализированная группа рекультивации ООО «СУЭК-Хакасия», КФХ В.Н. Кудашов (тел: 8 (961) 742-42-24, e-mail: kudashov82@mail.ru) в специальных горшках-контейнерах (кассетах) с использованием биопрепарата «Байкал - ЭМ 1» [10]. Прижившиеся саженцы высаживаются на отвалах рядовым способом по схеме: 1,5-1,8×0,8-1,1 м (5 тыс. шт./га).

При формировании лесополосы на уступах по периметру следует придерживаться ширины 12 м, насаждения должны состоять из: первый ряд - вяз мелколистный (Ulmus parvifolia Jacq); второй ряд - береза повислая (Betula pendula Roth); третий ряд - сосна обыкновенная (Pinus sylvestris L.). Расстояние между деревьями в рядах $-5 \times 6 \mathrm{~m}$.

Преимущество использования саженцев с закрытой корневой системой заключается в:

- отсутствии риска нарушения корневой системы при пересадке;

- возможности производить посадку в оптимальные по увлажнению сроки;

- отличной приживаемости саженцев - 90-98\%;

- сокращении сроков выращивания посадочного материала в два раза (в открытом грунте саженцы до стандартной высоты в 12 см растут 3 года, в теплицах - всего 1 год);

- микробиологическое освоение корнеобитаемого слоя отвалов идет вместе с ростом корней.

\section{ЗАКЛЮЧЕНИЕ}

Таким образом, научно обоснованные инновационные методы рекультивации отвалов угледобывающих предприятий в криоаридных условиях Средней Сибири, включенные в ГОСТ Р № 57446-2017 [11], дают возможность проектировать и получать экспертную оценку создания и развития экологически и экономически эффективных горных предприятий. Однако инновационные методы являются интеллектуальной собственностью и попадают под действие статьи 1229 ГК РФ.

\section{Список литературы}

1. Государственные доклады о состоянии окружающей среды Республики Хакасия в Правительство Республики Хакасия, 2000-2014 гг. [Электронный ресурс]. URL: https://r-19.ru/authorities/ministry-of-industry-and-naturalresources-of-the-republic-of-khakassia/docs/290/ (дата обращения: 15.09.2018).

2. Копылов А.И., Манаков Ю.А., Куприянов А.Н. Развитие угледобычи и проблемы сохранения экосистем в Кузбассе. // Уголь. 2017. № 3. С. 74. URL: http://www.ugolinfo.ru/ Free/032017.pdf (дата обращения: 15.09.2018).

3. Способ формирования корнеобитаемого слоя поверхности отвалов, образованных открытой разработкой полезных ископаемых, для биологической рекультивации / А.Т. Лавриненко, В.А. Андроханов: пат. 2478165 Российская Федерация. МПК Е 21 C 41/32 (2006.01). Заявитель и патентообладатель Лавриненко А.Т., Андроханов В.А. № 2011127273/03; заявл. 01.07.2011; опубл. 27.03.2013. Бюл. № 9.4 C.

4. Способ формирования и подготовки внешних отвалов и карьерных выемок для биологической рекультивации / А.Т. Лавриненко: пат. 2359127 Российская Федерация. МПК Е 21 C 41/32 (2006.01). Заявитель и патентообладатель ГНУ Научно-исследовательский институт аграрных проблем Хакасии СО Россельхозакадемии (RU). № 2007108870/03; заявл. 09.03.2007; опубл. 20.06.2009. Бюл. № 17.5 с.

5. Очаговый способ рекультивации горных отвалов / А.Т. Лавриненко: пат. 2343286 Российская Федерация. МПК Е 21C 41/32 (2006.01). Заявитель и патентообладатель ГНУ Научно-исследовательский институт аграрных проблем Хакасии СО РАCXH (RU). № 2007117479/03; заявл. 10.05.2007; опубл. 10.01.2009. Бюл. № 1. 4 с.

6. Способ формирования отвалов для технической рекультивации при открытой разработке карьеров / А.Т. Лавриненко: пат. 2388912 Российская Федерация. МПК Е 21C 41/32 (2006.01). Заявитель и патентообладатель ГНУ Научно-исследовательский институт аграрных проблем Хакасии СО РАCXH (RU). № 2008131248/03; заявл. 28.07.2008; опубл. 10.05.2010. Бюл. № 13. 4 с.

7. Способ биологической рекультивации горных отвалов / Л.С. Галенковская, В.Н. Кудашов, А.Т. Лавриненко, Д.Д. Новак, О.С. Сафронова, И.Н. Евсеева: пат. 2498069 Российская Федерация. МПК Е 21С 41/32 (2006.01). Заявитель и патентообладатель Государственное научное учреждение Научно-исследовательский институт аграрных проблем Хакасии Россельхозакадемии (RU). № 2009103505/03; заявл. 02.02.2009; опубл. 10.11.2013. Бюл. № 31. 3 с.

8. Методические рекомендации «Рекультивация земель, нарушенных угледобывающими предприятиями респу- 
блики Хакасия» / А.Т. Лавриненко, Е.А. Моршнев, О.С. Сафронова, И.Н. Евсеева и др. Новосибирск:Издательство Окарина, 2016. 40 с.

9. Куприянов А.Н., Манаков Ю.А., Баранник Л.П. Восстановление экосистем на отвалах горнодобывающей промышленности Кузбасса. Новосибирск: Академическое издательство «Гео», 2010. 160 с.

10. Использование ЭМ-технологий для рекультивации техногенных ландшафтов на угольных разрезах Красноярского края / В.А. Андроханов, А.Т. Лавриненко, А.А. Новицкий, Н.М. Колычев и др. // Вестник кадровой политики, аграрного образования и инноваций. 2013. № 1-3. C. 51-58.
11. ГОСТ Р 57446-2017. «Наилучшие доступные технологии. Рекультивация нарушенных земель и земельных участков. Восстановление биологического разнообразия», утвержденный и введенный в действие Приказом Федерального агентства по техническому регулированию и метрологии от 18 апреля 2017 г. № 283-ст.», п.11.5.2, п.11.5.2.12.

12. Андроханов В.А., Лавриненко А.Т. Ускорение процессов рекультивации техногенных ландшафтов на угольных предприятиях КАТЭКа и Хакасии // Уголь. 2012. № 7. С. 6266. URL: http://www.ugolinfo.ru/Free/072012.pdf (дата обращения 15.09.2018).

UDC 622.85:622.882 @ A.T. Lavrinenko, E.A. Morshnev, 2018

ECOLOGY

ISSN 0041-5790 (Print) • ISSN 2412-8333 (Online) • Ugol' - Russian Coal Journal, 2018, № 10, Pp. 94-97

Title

INNOVATIVE METHODS OF RECULTIVATION OF DUMPS OF COAL-MINING ENTERPRISES IN CRYOARID CONDITIONS OF MIDDLE SIBERIA

DOI: http://dx.doi.org/10.18796/0041-5790-2018-10-94-97

\section{Authors}

Lavrinenko A.T. ${ }^{1}$, Morshnev E.A.

1 "Scientific-Research Institute of Agrarian Problems of Khakassia" FSBI, Zelenoe village, 655132, Republic of Khakassia, Russian Federation

\section{Authors' Information}

Lavrinenko A.T., Manager Group of recultivation lands, tel.: +7 (39032) 2-56-09, e-mail: aleks233@yandex.ru

Morshnev E.A., Research engineer Group of recultivation lands, tel.: +7 (39032) 2-56-09, e-mail: morshnev86@mail.ru

\section{Abstract}

Article lights a recultivation perspective technogenically disturbed of the broken lands from the point of view of motivation of the coal-mining enterprises to application of new, regional, efficient methods of restitution of the broken lands in specific cryoarid conditions of the South of Middle Siberia. The innovative methods in problem solving of technical and biological recultivation based on use of regional state standard specification with the short description of design decisions are offered. All complex of actions for recultivation is reasoned. Justifications on decrease in costs for restitution of the destroyed territories at coal mining are given.

\section{Keywords}

Recultivation, Techno-earth, Ecologically efficient methods, Dump, FSL, Growth centers, Formation, Way, Innovative, Dragee, Root layer.

\section{References}

1. Gosudarstvennye doklady o sostoyanii okruzhayushchey sredy Respubliki Khakasiya v Pravitelstvo Respubliki Khakasiya 2000-2014 gg [State reports on environmental health of the Republic of Khakassia to the Government of the Republic of Khakassia], 2000-2014. [Web-site]. Available at: https://r-19.ru/ authorities/ministry-of-industry-and-natural-resources-of-the-republic-ofkhakassia/docs/290/ (accessed 15.09.2018).

2. Kopytov A.I., Manakov Yu.A. \& Kupriyanov A.N. Razvitie ugledobychi i problemy sokhraneniya ekosistem $v$ Kuzbasse [Coal mining and issued of ecosystem preservation in Kuzbass]. Ugol' - Russian Coal Journal, 2017, No. 3, p. 74 Available at: http://www.ugolinfo.ru/Free/032017.pdf (accessed 15.09.20183. Lavrinenko A.T. \& Androhanov V.A. Sposob formirovaniya korneobitaemogo sloya poverkhnosti otvalov obrazovannykh otkrytoy razrabotkoy poleznykh iskopaemykh dlya biologicheskoy rekultivatsii [Method of forming root habitable layer on the surface of opencast coal mine dumps for biological recultivation] Patent 2478165 Russian Federation, MPK E 21 C 41/32 (2006.01). Applicant and patent holder Lavrinenko A.T., Androhanov V.A., No. 2011127273/03; application date 01.07.2011; publication date 27.03.2013, Bul. No. 9, 4 p. 4. Lavrinenko A.T. Sposob formirovaniya i podgotovki vneshnikh otvalov i karernykh vyemok dlya biologicheskoy rekultivatsii [The way of formation and preparation of external dumps and mining excavations for biological recultivation]. Patent 2359127 Russian Federation, MPK E 21 C 41/32 (2006.01). Applicant and patent holder State Scientific Research Institute of Agrarian Problems of Khakassia, Siberian Branch of the Russian Academy of Agricultural Sciences (RU), No. 2007108870/03; application date 09.03.2007; publication date 20.06.2009, Bul. No. 17, 5 p.
5. Lavrinenko A.T. Ochagovyy sposob rekultivatsii gornykh otvalov [Focal method of mining dumps reclamation]. Patent 2343286 Russian Federation, MPK E 21C 41/32 (2006.01). Applicant and patent holder State Scientific Research Institute of Agrarian Problems of Khakassia, Siberian Branch of the Russian Academy of Agricultural Sciences (RU), No. 2007117479/03; application date 10.05.2007; publication date 10.01.2009, Bul. No. 1, 4 p.

6. Lavrinenko A.T. Sposob formirovaniya otvalov dlya tekhnicheskoy rekultivatsii pri otkrytoy razrabotke karerov [Method of forming dumps for technical reclamation in open quarrying]. Patent 2388912 Russian Federation, MPK E 21C 41/32 (2006.01). Applicant and patent holder State Scientific Research Institute of Agrarian Problems of Khakassia, Siberian Branch of the Russian Academy of Agricultural Sciences (RU), No. 2008131248/03; application date 28.07.2008; publication date 10.05.2010, Bul. No. 13, 4 p.

7. Galenkovskaya L.S., Kudashov V.N., Lavrinenko A.T., Novak D.D., Safronova O.S. \& Evseeva I.N.Sposob biologicheskoy rekultivatsii gornykh otvalov [Method of biological recultivation of mining dumps]. Patent 2498069 Russian Federation, MPKE 21C 41/32 (2006.01). Applicant and patent holder State Scientific Research Institute of Agrarian Problems of Khakassia, Siberian Branch of the Russian Academy of Agricultural Sciences (RU), No. 2009103505/03; application date 02.02.2009; publication date 10.11.2013, Bul. No. 31, 3 p.

8. Lavrinenko A.T., Morshnev E.A., Safronova O.S., Evseeva I.N. et al. Metodicheskie rekomendatsii "Rekultivatsiya zemel narushennykh ugledobyvayushchimi predpriyatiyami respubliki Khakasiya" [Methodical recommendations "Reclamation of lands disturbed by coal-mining enterprises of the Republic of Khakassia"]. Novosibirsk, Okarina Publ., 2016, 40 p.

9. Kupriyanov A.N., Manakov Yu.A. \& Barannik L.P. Vosstanovlenie ekosistem na otvalakh gornodobyvayushchey promyshlennosti Kuzbassa [Restoration of ecosystems on Kuzbass mining dumps]. Novosibirsk, Akademicheskoe izdatelstvo Geo Publ., 2010. 160 p.

10. Androkhanov V.A., Lavrinenko A.T., Novitskiy A.A., Kolychev N.M. et al. Ispolzovanie EM-tekhnologiy dlya rekultivatsii tekhnogennykh landshaftov na ugolnykh razrezakh Krasnoyarskogo kraya [Use of EM technologies for reclamation of man-made landscapes on coal mines of the Krasnoyarsk Territory]. Vestnik Kadrovoy Politiki, Agrarnogo Obrazovaniya i Innovaciy - Bulletin of HR Policy, Agrarian Education and Innovations, 2013. No. 1-3, Pp. 51-58.

11. GOST R 57446-2017 "Nailuchshie dostupnye tekhnologii. Rekultivatsiya narushennykh zemel i zemelnykh uchastkov. Vosstanovlenie biologicheskogo raznoobraziya" [Best available techniques. Disturbed lands reclamation. Restoration of biological diversity]. Approved and enforced by the Order of the Federal Agency for Technical Regulation and Metrology dd. April 18, 2017, No. 283 - st., Section 11.5.2, Section 11.5.2.12.

12. Androkhanov V.A. \& Lavrinenko A.T. Uskorenie processov rekul'tivacii tehnogennyh landshaftov na ugol'nyh predprijatijah KATJeKa i Hakasii [Acceleration of processes of a recultivation of technogenic landscapes at coal enterprises KATEK and Khakasia]. Ugol' - Russian Coal Journal, 2012, No. 7, Pp. 62-66. Available at: http://www.ugolinfo.ru/Free/072012.pdf (accessed 15.09.2018). 


\section{Влияние угольной}

\section{промышленности Кузбасса}

\section{на экологическую и продовольственную безопасность региона}

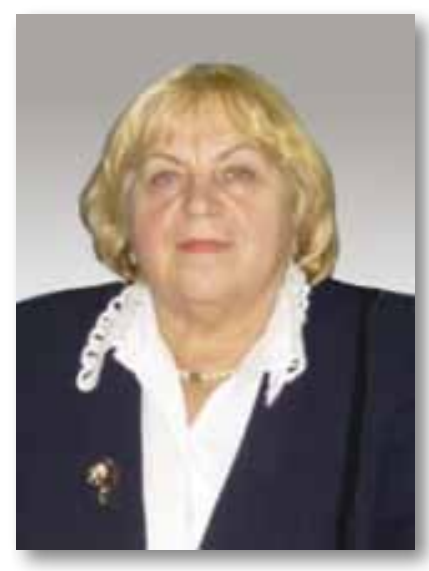

ТРУШИНА Галина Семеновна Доктор экон. наук, профессор кафедры «Производственный менеджмент» КузГТУ им. Т.Ф. Горбачева, 650026, г. Кемерово, Россия, e-mail: lilia.au@mail.ru
С целью сохранения экологической и продовольственной безопасности Кемеровской области обоснована необходимость согласования Министерства природных ресурсов и экологии Российской Федерации с Администрацией Кемеровской области при выдаче лицензий на добычу угля. Показаны проблемы и основные пути сохранения экологии, природного ландшафта и продовольственной безопасности региона.

Ключевые слова: Кузбасс, население, природный ландшафт, добыча угля, проблемы, лицензии, Минприроды России, рекультивация, экология, продовольственная безопасность.

\section{ВВЕДЕНИЕ}

Добыча угля в Кузбассе в 2017 г. составила 241,5 млн т, потребность в кузнецком угле на российском рынке стабильная (около 100,5 млн т), рост добычи угля объясняется переориентацией на экспортные поставки. Не учитывая экологическую емкость региона, Минприроды России без согласования с Администрацией Кемеровской области уже выдало лицензии на 350 млн т добычи угля на территориях зачастую с развитой инфраструктурой, экологически чистыми посевными полями и деревнями. Кемеровская область является экологически и сейсмически неблагоприятным субъектом Российской Федерации. Необходимо в законодательной форме определить порядок отведения недр с учетом интересов не только государства, но и территорий. Ростехнадзору целесообразно решить вопрос с Правительством Российской Федерации о пересмотре видов работ по рекультивации нарушенных земель и сроков их выполнения в соответствии со стандартами таких стран, как, США и Германия.

\section{ПРОБЛЕМЫ РАЗВИТИЯ УГОЛЬНОЙ}

\section{ПРОМЫШЛЕННОСТИ В КУЗБАССЕ}

Добыча угля в Кузбассе в 2017 г. увеличилась по сравнению с 2009 г. на 33,2\% и достигла рекордного уровня 241,5 млн т, или 59,1\% от добычи в РФ [1], подземным способом добыто 35,2\%, открытым - 64,8\%, функционировали 42 шахты, 51 разрез, 54 обогатительные фабрики. Эффективность предприятий угольной промышленности повышается. За период 2010-2017 гг. при росте добычи на 21,4\% численность трудящихся сократилась на 18768 чел., или на 16,6\%, но наблюдаются текучесть и нехватка квалифицированных кадров $[2,3,4,5]$.

Резкое наращивание добычи угля, в основном, более дешевым открытым способом, объясняется увеличением поставок угля на экспорт. В 2017 г. в 61 страну мира отправлено 131,7 млн т (по данным Кемеровостата), или 72,5\% общего экспорта России и 54,5\% добычи кузнецкого угля. Из данных, отраженных на рисунке, следует, что ежегодный темп прироста добычи (2012 г. - 4,8\%; 2013 - 0,5\%; 2014 г. - 4,0\%, 2015 г. - 2,1\%; 2016 г. - 5,7\%; 2017 г. - 6,2\%) продолжался и в период резкого снижения цен на уголь (в 2 раза) на мировом рынке с 2012 г. до середины 2016 г.

Угли Кузбасса выдержали конкуренцию благодаря колебанию курса рубля в сторону его уменьшения за период 2014-2018 гг. более, чем в 2 раза. Ориентация угольной промышленности Кузбасса на экспорт связана с большими рисками. В случае изменения курса рубля в сторону его роста, при очередном понижении цен на уголь на мировом рынке, выдержать конкуренцию будет проблематично. Одной из серьезных проблем являются более высокие затраты на транспортировку угля на экспорт по сравнению с другими угольными бассейнами, так как радиус доставки превышает 4000-5000 км. 


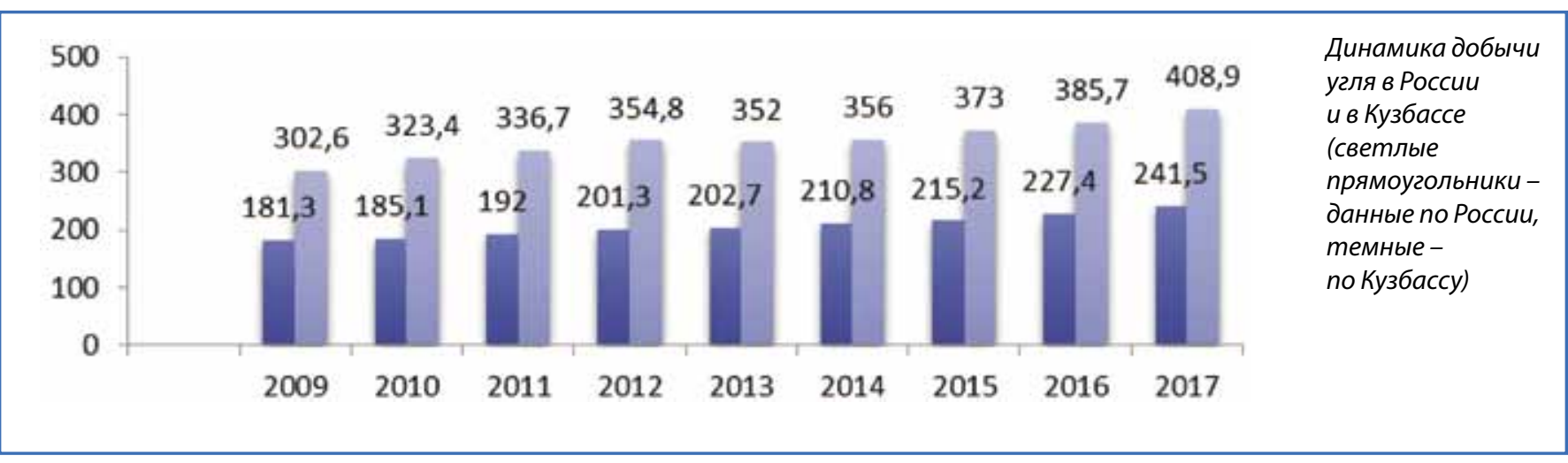

Из-за изменения конъюнктуры мирового угольного рынка рост добычи угля сопровождался уменьшением размера налогов в бюджет области. Так, за период 2011-2016 гг. добыча угля увеличилась в 2015 г. от уровня 2011 г. на 12\%, в 2016 г. - на 18,4\%, а налоги в бюджет области уменьшились соответственно на 54,1\% и на 31,7\%. В 2016 г. доля отчислений в бюджет области составила лишь 20,4\% (23,078 млрд руб.) [6], в 2017 г. - 37\% (50 млрд руб.) за счет роста цен и одновременного снижения курса рубля. За период январь-май 2018 г. (по данным Кемеровостата) доля убыточных предприятий по добыче угля составила 28,7\%, на 8\% больше, чем в аналогичном периоде 2017 г.

Несмотря на то, что в Кузбассе ведется работа по переходу предприятий на более чистые технологии добычи и переработки угля, экологический ущерб от деятельности ряда шахт и, особенно, разрезов, получающих $80 \%$ от прибыли, несопоставим с размером налоговых отчислений в бюджет области и РФ. Если учитывать то, что ряд предприятий путем перепродажи участков могут быть зарегистрированы или проведены как филиалы предприятий за пределами области, то суммы налоговых отчислений от прибыли в область вообще могут не поступить.

В целях получения большего размера прибыли не все предприятия выполняют требования по рекультивации нарушенных земель, после отработки запасов в области остаются огромные территории, напоминающие лунный ландшафт.

Для проведения работ по восстановлению природного ландшафта необходимо использовать технологию рекультивационных работ США и Германии [7, 8]. Особого внимания заслуживает опыт муниципалитетов, ежегодно утверждающих разрешение предприятиям на добычу угля при условии перечисления до начала года резервной суммы на особые счета муниципалитета, необходимой на полное восстановление нарушенных земель и природоохранные мероприятия. Если в течение года данные виды работ выполняются силами предприятия, то резервные денежные средства возвращаются. В противном случае финансирование на выполнение запланированных рекультивационных работ передается специализированным организациям [9].

Правительством Российской Федерации от 21 июня 2014 г. (№ 1099-р) утверждена «Программа развития угольной промышленности России на период до 2030 года», в которой предусмотрено масштабное смещение угледобычи на Восток страны. Приоритет лицензирования недропользования до 2030 г. будет направлен на поддержание и создание новой минерально-сырьевой базы угольной промышленности в районах Восточной Сибири, Дальнего Востока, Байкальского региона, Печорского угольного бассейна. Добычу угля к 2030 г. в РФ предполагается увеличить до 410-480 млн т, в основном за счет ДФО и Восточной Сибири, в Кузбассе прогнозируется 205 - 238 млн т. Добыча угля в Кузбассе в 2017 г. уже составила 241,5 млн т. Это объясняется тем, что, не учитывая решение правительства, сейсмическую активность и экологическую емкость региона, Минприроды России без согласования с Администрацией Кемеровской области уже выдало лицензии на 350 млн т добычи кузнецких углей [10]. Департаментом по недропользованию по СФО выставляются на продажу участки угольных месторождений, в большей степени благоприятные для более дешевого способа добычи угля открытым способом, зачастую на территориях с развитой инфраструктурой. Несмотря на то, что Администрация КО иногда добивается отмены ряда аукционов по продаже участков в плодородных и экологически наиболее чистых регионах Кузбасса $[10,11]$, как показывает практика 2017-2018 гг., их выставляют вновь на продажу (например, участок «Искитимский-1» Титовского каменноугольного месторождения с прилегающими семи поселками и деревнями). Деятельность Минприроды России угрожает экологической и продовольственной безопасности Кемеровской области [11]. В настоящий период область не может полностью обеспечить себя экологически чистыми продуктами животноводства и зерновыми культурами. К сожалению, по данным ФСГС по Кемеровской области, смертность населения в 2017 г. опережала рождаемость на 34,7\%. С 2003 по 2017 г. из области выехало 198,6 тыс. чел., общая численность на 01.01.2018 составила 2694,9 тыс. чел., из них доля сельского населения - всего 14\%. Трудоспособное население снизилось на 325,9 тыс. чел. В сельском и лесном хозяйстве, охоте, рыболовстве и рыбоводстве занято всего 11,9 тыс. чел., или 1,5\%. Безработных в области - 95,1 тыс. чел. Среднегодовая численность занятых в экономике составила 811,7 тыс. чел., из них в угольной промышленности - 94 тыс. чел., или 11,6\%.

Кемеровская область является экологически неблагоприятным субъектом РФ. Ученые СО РАН и СПГУ, проведя научные исследования в условиях 2012 г., определили экологическую емкость региона и предельный объем добычи угля в Кузбассе на уровне 200 млн т в год [12]. В регионе, кроме экологического ущерба прошлых лет, ежегодно добавляются вредные выбросы в атмосферу, уничтоженные лесные массивы, пахотные земли из-за резкого увеличения добычи угля, в основном открытым спосо- 
бом. На 01.01.2018 более 92,4\% твердых промышленных отходов образовано угольной отраслью, нарушено 66 тыс. га земли, во внешних отвалах размещено более 17 млрд т породы [5], выбросы загрязняющих атмосферу веществ (по данным ФСГС по Кемеровской области) за 2017 г. составили 813,8 тыс. т, или 65\% общего объема выбросов.

Проблемой для наращивания добычи угля является также то, что Кемеровская область является сейсмически активной. В результате землетрясения интенсивностью 7 баллов в июне 2013 г. в Беловском районе были повреждены 365 объектов социальной сферы и ЖКХ, более 5 тыс. частных и 300 многоквартирных жилых домов. Подземные толчки часто повторяются. Последнее землетрясение произошло 30.07.2018 в 84 км от г. Кемерово интенсивностью в эпицентре 4,1 балла. По мнению многих ученых, землетрясения провоцируются ежегодными (более 3 тыс.) промышленными взрывами на угольных разрезах с магнитудой до 3,5 баллов с использованием 600 тыс. т взрывчатки. Общая протяженность подземных горных выработок составляет 5,3 тыс. км [10].

\section{ЗАКЛЮЧЕНИЕ}

В Российской Федерации необходимо в законодательной форме определить порядок отведения недр с учетом интересов не только государства, но и территорий. Министерству природных ресурсов и экологии Российской Федерации, Департаменту по недропользованию по СФО необходимо согласовывать выдачу лицензий на добычу угля с территориальными властями. Ростехнадзору - ужесточить контроль за деятельностью Сибирского Управления Федеральной службы по экологическому, технологическому и атомному надзору, которое наделено полномочиями по выдаче предписаний угледобывающим предприятиям в случае невыполнения необходимых работ по рекультивации и несоблюдению нормативов по охране окружающей среды. Для сохранения природного ландшафта территорий, нарушенных в результате выемки угля, Ростехнадзору целесообразно решить вопрос с Правительством Российской Федерации о пересмотре сроков выполнения и видов работ по рекультивации нарушенных земель в соответствии с европейскими стандартами (например, Германии) и США, а также о повышении федеральных норм по минимальному расстоянию разрезов до населенных пунктов (в настоящий период - всего 1 км, до отвалов - 500 м; например, вокруг от 1 до 8 км от окраин с. Каракан с населением до 900 человек, действуют участки шести разрезов, в том числе вблизи от села участок разреза «Моховский» с самовозгорающимися пластами, несколько угольных складов и ОФ), что способствует росту легочных и других заболеваний [12]; в законодательном порядке существенно увеличить размеры штрафных санкций к предприятиям, не соблюдающим нормативы по охране окружающей среды и рекультивации нарушенных земель, а также к тепловым электростанциям, использующим низкокачественные угли.

В целях сохранения экологической и продовольственной безопасности региона, по нашему мнению, необходимо прекратить наращивание мощностей открытого способа добычи, более экологичным является подземный способ добычи угля. Учитывая неблагоприятную экологиче- скую и сейсмическую обстановку в регионе, органам власти при решении вопроса о выдаче лицензий на добычу угля, по нашему мнению, необходимо повторно провести научные исследования по определению экологической емкости региона и предельного объема добычи угля в условиях современной технологии ведения горных работ.

\section{Список литературы}

1. Таразанов И.Г. Итоги работы угольной промышленности России за январь-декабрь 2017 года // Уголь. 2018. № 3. C. 58-73. doi: 10.18796/0041-5790-2018-3-58-73. URL: http://www.ugolinfo.ru/bgdev/Jour/032018.pdf (дата обращения: 15.09.2018).

2. Трушина Г.С. Экономическая оценка стратегии функционирования угледобывающего предприятия //Уголь. 2017. № 3. C. 52-55. URL: http://www.ugolinfo.ru/Free/032017.pdf (дата обращения: 15.09.2018).

3. Трушина Г.С. Основные пути эффективного развития предприятий угольной промышленности Кузбасса // Известия вузов. Горный журнал. № 6. 2017. С. 25-30.

4. Трушина Г.С., Орлов И.А. Ситуация на рынке труда и проблемы формирования кадрового потенциала на угледобывающих предприятиях Кузбасса // Уголь. 2012. № 12. C. 73-76. URL: http://www.ugolinfo.ru/Free/122012.pdf (дата обращения: 15.09.2018).

5. Власти Кузбасса подвели итоги работы угольной отрасли за 2017 год. [Электронный ресурc]. URL: http://толк42. pф/show2/3407/ (дата обращения: 15.09.2018).

6. Хлебунов Е. Угольная отрасль региона будет еще долгие годы служить гарантом динамичного развития Кемеровской области. [Электронный ресурс]: URL: https://www.rosugol.ru/news/articles.php?ELEMENT_ ID=23569.14.06.2017 (дата обращения: 15.09.2018).

7. Jason Hayes. Returning Mined Land to Productivity Through Reclamation. Winter 2015 Cornerstone. Vol. 3. N 4. URL: www.worldcoal.org (дата обращения: 15.09.2018).

8. Warrick J. \& Mufson S. (2015, August 3). Enemies of the net-plan air rules multi-faceted battle // Washington post. URL: www.washingtonpost.com/national/health-science/ opponents-lay: the Foundation for state control of pollutantsborders. 2015/08/03/ (дата обращения: 15.09.2018).

9. Miller C.G. Financial Assurance for Mine Closure and Reclamation. Ottawa, Canada. February 2005. URL: http://www. icmm.com/website/publications/pdfs/mine-closure/282.pdf (дата обращения: 15.09.2018).

10. Аман Тулеев: Кузбасс продолжает ставить мировые рекорды по добыче угля. [Электронный ресурс]. URL: https://www.rosugol.ru/news/articles.php?ELEMENT_ ID=23923 (дата обращения: 15.09.2018).

11. Коротич С. Цивилев попросил главу Минприроды РФ помочь отменить аукцион на добычу угля. [Электронный ресурс]. URL: https://ksonline.ru/322235/sergej-tsivilevpoprosil-glavu-minprirody-rf-pomoch-otmenit-auktsion-nadobychuuglya/.21.06.2018 (дата обращения: 15.09.2018).

12. Мун С.А., Ларин С.А., Глушков А.Н. Влияние роста добычи угля на загрязнение атмосферы и заболеваемость раком легкого в Кемеровской области // Современные проблемы науки и образования. 2013. № 1. URL: https:// science-education.ru/ru/article/view?id=8406 (дата обращения: 15.09.2018). 
UDC 662.85:622.33(571.17):330.15:332.363 @ G.S. Trushina, 2018

ISSN 0041-5790 (Print) • ISSN 2412-8333 (Online) • Ugol' - Russian Coal Journal, 2018, № 10, Pp. 98-101

Title

THE INFLUENCE OF THE KUZBASS COAL INDUSTRY ON THE ECOLOGICAL AND FOOD SECURITY OF THE REGION

DOI: http://dx.doi.org/10.18796/0041-5790-2018-10-98-101

\section{Author}

Trushina G.S.1

${ }^{1}$ T.F. Gorbachev Kuzbass State Technical University (KuzSTU), Kemerovo, 650000, Russian Federation

\section{Authors' Information}

Trushina G.S., Doctor of Economic Sciences, Professor at "Production Management" Department, e-mail: lilia.au@mail.ru

\begin{abstract}
In order to preserve ecological and food security of the Kemerovo region, the article justifies the necessity to align the issuance of licenses for coal mining by the Ministry of Natural Resources and Ecology of the Russian Federation with the Administration of the Kemerovo Region. The problems and main ways to preserve healthy environment, natural landscape and food security of the region are shown.
\end{abstract}

\section{Keywords}

Kuzbass, Population, Natural landscape, Coal mining, Problems, Licenses, Ministry of Natural Resources of the Russian Federation, Recultivation, Environment, Food security.

\section{References}

1. Tarazanov I.G. Itogy raboty ugol'noy promishlennosty Rossii za yanvar dekabr 2017 [Russia's coal industry performance for January - December, 2017]. Ugol' - Russian Coal Journal, 2018, No. 3, Pp. 58-73. doi: 10.18796/00415790-2018-3-58-73. Available at: http://www.ugolinfo.ru/bgdev/Jour/032018. pdf (accessed 15.09.2018).

2. Trushina G.S. Ekonomicheskaya otsenka strategii funktsionirovaniya ugledobyvayushchego predpriyatiya [Mining enterprise performance strategy economic evaluation]. Ugol' - Russian Coal Journal, 2017, No. 3, Pp. 52-55 Available at: http://www.ugolinfo.ru/Free/032017.pdf (accessed 15.09.2018). 3. Trushina G.S. Osnovnye puti effektivnogo razvitiya predpriyatiy ugolnoy promyshlennosti Kuzbassa [The main ways of effective development of the coal industry enterprises of Kuzbass]. Izvestiya Vuzov. Gornyy Zhurnal - Proceedings of High Schools. Mining Journal, No. 6, 2017, Pp. 25-30.

4. Trushina G.S. \& Orlov I.A. Situacija na rynke truda i problemy formirovanija kadrovogo potenciala na ugledobyvajushhih predprijatijah Kuzbassa [The situation in the labor market and issues of staffing at Kuzbass's coal production companies]. Ugol' - Russian Coal Journal, 2012, No. 12, Pp. 73-76. Available at: http://www.ugolinfo.ru/Free/122012.pdf (accessed 15.09.2018).
5. Vlasti Kuzbassa podveli itogi raboty ugolnoy otrasliza 2017 god. [The authorities of Kuzbass summed up the work of the coal industry in 2017]. [Web-site]. Available at: http://толк42.pф/show2/3407/. (accessed 15.09.2018).

6. Khlebunov E. Ugolnaya otras/ regiona budet eshche dolgie gody sluzhit garantom dinamichnogo razvitiya Kemerovskoy oblasti [The coal industry in the region will continue to serve as a guarantee for the dynamic development of the Kemerovo region for many years to come]. [Web-site]: Available at: https://www.rosugol.ru/news/articles.php?ELEMENT_ID=23569.14.06.2017. (accessed 15.09.2018).

7. Jason Hayes Returning Mined Land to Productivity Through Reclamation. Winter 2015 Cornerstone, Vol. 3, No. 4. Available at: www.worldcoal.org. (accessed 15.09.2018).

8. Warrick J. \& Mufson S. (2015, August 3). Enemies of the net-plan air rules multi-faceted battle. Washington post. Available at: www.washingtonpost. com/national/health-science/opponents-lay: the Foundation for state control of pollutants-borders. 2015/08/03/ (accessed 15.09.2018).

9. Miller C.G. Financial Assurance for Mine Closure and Reclamation. Ottawa, Canada, February 2005. Available at: http://www.icmm.com/website/publications/pdfs/mine-closure/282.pdf. (accessed 15.09.2018).

10. Aman Tuleev: Kuzbass prodolzhaet stavit mirovye rekordy po dobyche uglya [Kuzbass continues to set world records for coal mining]. [Web-site]. Available at: https://www.rosugol.ru/news/articles.php?ELEMENT_ID=23923. (accessed 15.09.2018).

11. Korotich S. Tsivilev poprosil glavu Minprirody RF pomoch otmenit auktsion na dobychu uglya [Tsivilev asked the head of the Ministry of Natural Resources of the Russian Federation to help cancel the auction for the extraction of coal] [Web-site]. Available at: https://ksonline.ru/322235/sergejtsivilev-poprosil-glavu-minprirody-rf-pomoch-otmenit-auktsion-na-dobychuuglya/.21.06.2018. (accessed 15.09.2018).

12. Mun S.A., Larin S.A. \& Glushkov A.N. Vliyanie rosta dobychi uglya na zagryaznenie atmosfery i zabolevaemosti rakom legkogo v Kemerovskoy oblasti [Influence of coal production growth on air pollution and lung cancer incidence in the Kemerovo region]. Sovremennye Problemy Nauki iObrazovaniyaProblems of Modern Science and Education. 2013. No. 1. Available at: https:// science-education.ru/ru/article/view?id=8406. (accessed 15.09.2018).

\section{СУЭК подарила новый компьютерный класс Новочарской школе № 2}

Компьютерное оборудование для школы № 2 п. Новая Чара Каларского района Забайкальского края приобретено при финансовой поддержке ФонӘa «СУЭК-РЕГИОНАМ».

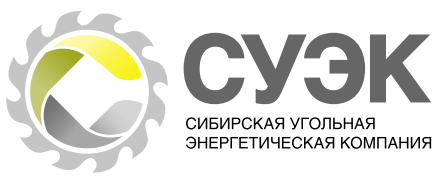

В День знаний горняки Апсатского разреза, входящего в состав СУЭК, торжественно передали компьютерное оборудование Новочарской школе № 2. Новый класс будет состоять из 17 современных компьютеров на базе двухъядерных процессоров INTEL и с новыми версиями офисных продуктов Microsoft.
«ССибирской угольной энергетической компанией мы тесно дружим. При поддержке Фонда «СУЭК-РЕГИОНАМ» натерритории школы была построена многофункциональная спортивная площадка. С 2017 г. мы участвуем в проекте Трудовые отряды СУЭК. Также и Апсатский разрез принимает активное участие вжизни нашей школы. Предприятие помогло нам вывезти необходимое оборудование для кабинета доступной среды из краевого чентра, эстакаду соорудить на территории школьного автодрома», - рассказал Владимир Осипов, директор Новочарской СОШ № 2 имени Героя России Игоря Молдованова. 


\section{Инженерные решения по предотвращению пожаров на угольных разрезах Австралии}

DOI: http://dx.doi.org/10.18796/0041-5790-2018-10-102-103

\section{ЗЕНЬКОВ Игорь Владимирович}

Доктор техн. наук, Заслуженный эколог РФ, профессор Сибирского федерального университета, профессор ФГБУ ВО «Сибирский

государственный университет науки

и технологий им. академика М.Ф. Решетнёва»,

660049, г. Красноярск, Россия,

e-mail:zenkoviv@mail.ru

В статье представлены инженерные решения, практическая реализация которых позволяет на угольных разрезах Австралии существенно снизить риск возникновения возгораний угольных пластов при их разработке.

Ключевые слова: Австралия, штаты Квинсленд и Виктория, открытая угледобыча, угольные разрезы, возгорание угольных пластов, профилактика пожаров, противопожарные мероприятия.

\section{ВВЕДЕНИЕ}

К настоящему времени Австралия уверенно занимает одну из лидирующих позиций в мире по добыче угля открытым способом. Вместе с тем большие площади вскрытого угля являются реальной угрозой возникновения масштабных пожаров на угольных разрезах, при которых происходит гибель людей, уничтожение горнотранспортного оборудования, а также сокращение вскрытых запасов угля, подготовленного к выемке. На территории Австралии все угольные разрезы можно условно разделить на две группы - разрезы, отрабатывающие мощные (до 80 м) пласты бурого энергетического угля на юго-востоке материка в штате Виктория; разрезы, работающие на горизонтальных или слабонаклонных пластах вдоль восточного побережья в штатах Квинсленд и Новый Южный Уэльс. Некоторые разрезы из последней группы находятся в долинах рек Макензи и Досон.

На разрезах, входящих в первую группу, угольные пласты разрабатывают 3-4 уступами с применением роторных экскаваторов большой единичной мощности и транспортировкой угля по забойным конвейерам. При этом площадь вскрытого угля может достигать 180 га и более (разрез «Траралгон Восток»). На этом разрезе реализовано надежное решение, позволяющее на всем пути угля из забоя до котлов тепловых станций резко снизить риск его возгорания. Вдоль всех забойных конвейеров проложены трубы, в которые под давлением подается вода. Через вращающиеся сопла происходит орошение по- верхности угольного пласта и всего того, что находится на его поверхности (на рис. 1 в центре).

Площадь орошения пласта с одной трубы составляет 15 га. Это достигается за счет расположения сопел через 45-50 м. Давление воды в трубе обеспечивает дальность разлета водяной струи не менее 50 м. В полосе орошения находится угольный конвейер. Период интенсивного полива пластов - с декабря по май.

Угольные пласты горизонтального и наклонного залегания мощностью до 25 м разрабатывают блоками протяженностью 1,1-1,8 км каждый. На самом протяженном разрезе в мире «Моранба» длиной 50 км фронт горных работ разбит на 34 блока. Организация горных работ предусматривает разработку вскрытого пласта не на всем его протяжении. Часть блоков с горногеологическими характеристиками, обеспечивающими наилучшие технико-экономические показатели разреза, находится в разработке, а другая часть - в затопленном состоянии во избежание возникновения возгорания угольного пласта. В ситуации, когда в разрабатываемых блоках происходит ухудшение горно-геологических характеристик пластов, из блоков, находящихся в затопленном состоянии, откачивается вода с переливом в блоки, в которых накануне производилась добыча угля. Такой порядок отработки карьерных полей является типичным для угольных разрезов Австралии. На рис. 2 показан разрез «Кианга» протяженностью 25 км, где часть блоков разрабатывается, а часть находится в затопленном состоянии.

Только в одном блоке протяженностью 1,5 км площадь откоса угольного уступа и основания отработанного пла-

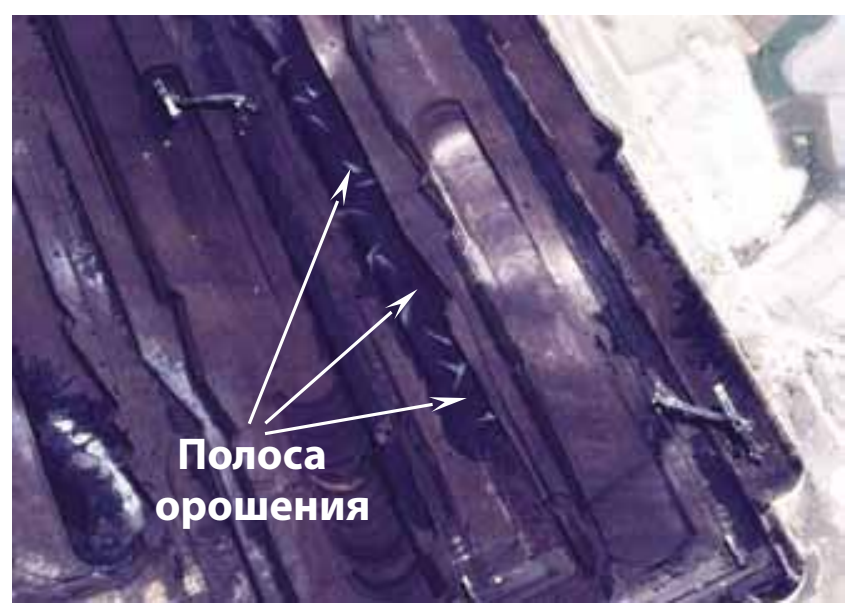

Рис. 1. Орошение поверхности угольного пласта на разрезе «Траралгон Восток» 


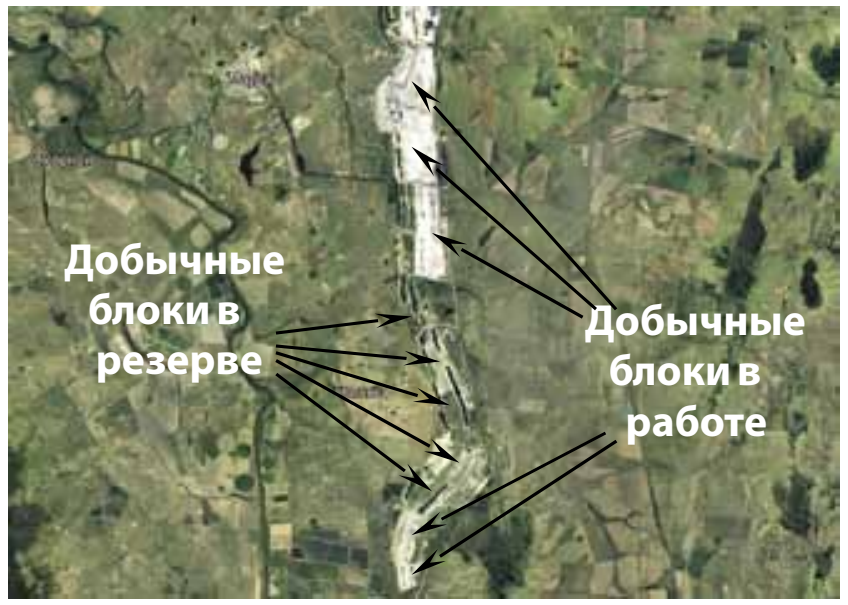

Рис. 2. Угольный разрез «Кианга» на снимке из космоса

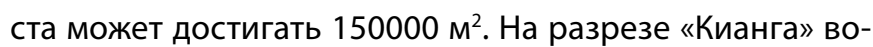
семь блоков общей протяженностью 13 км являются рабочими, а 21 блок длиной в диапазоне 380-1100 м находится в затопленном состоянии. По нашей оценке, объем воды в техногенных водоемах составляет не менее 18 млн $\mathrm{M}^{3}$. Время на перемещение воды между блоками зависит от количества и производительности насосов.

\section{ЗАКЛЮЧЕНИЕ}

В заключение отметим экономическую целесообразность внедрения подобных мероприятий по снижению риска возгорания угольных пластов в угледобывающем секторе Австралии, что может быть рекомендовано для российских угольных разрезов, где были случаи масштабного горения угольных пластов (разрез «Уртуйский», Бурятия, 2012 г.).

UDC 622.33.012.3(94):622.822.22 @ I.V. Zenkov, 2018

ABROAD

ISSN 0041-5790 (Print) • ISSN 2412-8333 (Online) • Ugol' - Russian Coal Journal, 2018, № 10, Pp. 102-103

Title

ENGINEERING SOLUTIONS FOR PREVENTION OF FIRES IN AUSTRALIAN COAL MINES

DOI: http://dx.doi.org/10.18796/0041-5790-2018-10-102-103

Author

Zenkov I.V. ${ }^{1,2}$

${ }^{1}$ Siberian Federal University, Krasnoyarsk, 660041, Russian Federation ${ }^{2}$ M.F. Reshetnev Siberian State University of Science and Technology, the Federal State-Funded Educational Institution of Higher Professional Education (FSFEI HPE), Krasnoyarsk, 660037, Russian Federation

Authors' Information

Zenkov I.V., Doctor of Engineering Sciences, Merited Ecologist of the Russian Federation, Professor, e-mail: zenkoviv@mail.ru

\section{Abstract}

The paper presents engineering solutions, practical implementation of which enables to significantly reduce the risk of coal seam fires during bank excavation on Australian coal mines.

\section{Keywords}

Australia, the states of Queensland and Victoria, Surface mining, Open-pit coal mines, Spontaneous combustion in coal seams, Fire prevention, Fire prevention measures.

\title{
КНИЖНАЯ НОВИНКА
}

\section{Стандартные методы испытания углей. Классификации углей}

\section{Авгушевич И.В., Сидорук Е.И., Броновец Т.М.}

\author{
М.: Издательство «Реклама мастер», 2018. 576 с. \\ ISBN 978-5-902989-59-2
}

Вышло в свет второе, дополненное издание руководства по методам анализа углей как сырья для энергетического и технологического использования.

Книга представляет собой методическое пособие и практическое руководство по методам оценки качества углей.

В книге обсуждается современное состояние аналитической химии твердых топлив. Рассмотрены основные стандартные методы испытаний углей, большинство из которых гармонизировано с требованиями международных стандартов. Изложены стандартные методы определения петрографического и химического состава углей, технического анализа, спекаемости и технологические методы испытания.

Дан анализ современных классификаций и кодификаций углей. Приведены примеры маркировки и кодификации углей.

Книга содержит обширный справочный материал по методам испытания углей.

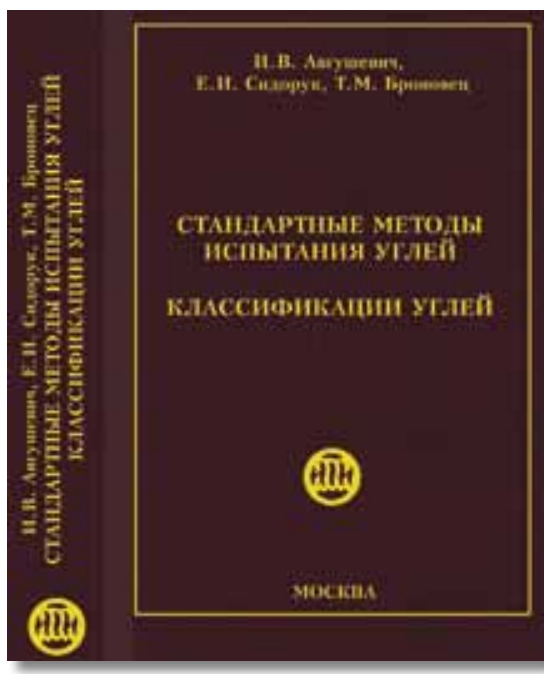

Книги высылаются наложенным платежом.

Вы оплачиваете только почтовые расходы («Почта России»).

Присылайте заявки по электронной почте: avgush@rambler.ru

Ирина Владимировна Авгушевич 

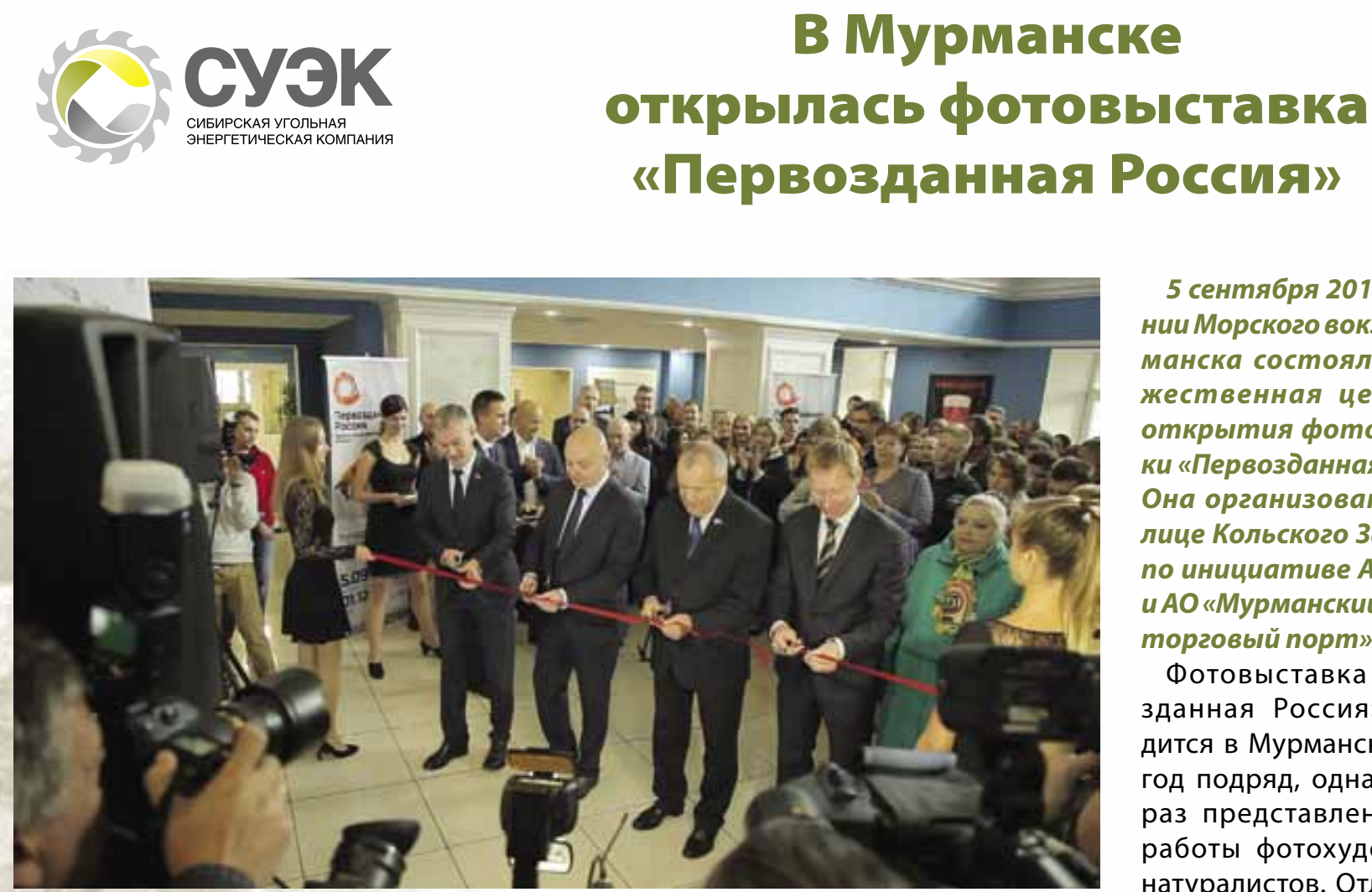

5 сентября 2018 г. в здании Морского вокзала Мурманска состоялась торжественная церемония открытия фотовыставки «Первозданная Россия». Она организована в столиче Кольского Заполярья по инициативе $A O$ «СУЭК» и АО «Мурманский морской морговый порт».

Фотовыставка «Первозданная Россия» проводится в Мурманске второй год подряд, однако в этот раз представлены новые работы фотохудожниковнатуралистов. Отличительной особенностью выставки этого года является ее тематика - дикие уголки арктических регионов нашей необъятной Родины. Следует отметить, что в числе выставленных фотографий присутствуют снимки мурманчанина Сергея Королева, который принял участие в торжественном открытии и рассказал о своих работах.

«В прошлом году выставку «Первозданная Россия» посетили более 52 mыс. человек. В этом году - новая экспозиция. Любой желающий может ознакомиться с 70 фотографиями. По инициативе $A O$ «СУЭК» и АО «ММТП» вход на выставку будет свободным для всех желающих», - отметил генеральный директор АО «Мурманский морской торговый порт» Александр Масько, приветствуя собравшихся.

«Придя на выставку, каждый может воочию убедиться в том, какими прекрасными и живописными местами обладает наша огромная страна», - отметил председатель Мурманской областной думы Сергей Дубовой, выразив слова благодарности организаторам мероприятия.

«Фотовыставка дает возможность увидеть уникальную природу России, в том числе и нашего региона. Яуверен, что «Первозданная Россия» станет важнейшим культурным событием Мурманска», - подчеркнул министр по внутренней политике и массовым коммуникациям Мурманской области Глеб Шинкарчук.

«Это яркое культурное событие в жизни нашего региона, которое напоминает каждому из нас о том, в какой замечательной и прекрасной стране мы живем. Не будет преувеличением сказать, что таким богатством живой природы, природными памятниками и живописными ландшафтами обладает только наша страна», - сказал глава муниципального образования город Мурманск Дмитрий Филиппов.

«Второй год подряд градообразующие предприятие Мурманска радует нас «Первозданной Россией». Такое событие грандиозного маситаба, не побоюсь этого слова, является очередным доказательством того, что портовики активно участвуют в общественной жизни нашего региона, а Мурманский морской торговый порт заботится о жителях города», - отметил глава регионального исполкома ОНФ в Мурманской области Максим Сахневич.

Фотовыставка «Первозданная Россия» - часть одноименного общероссийского культурно-просветительского проекта, который реализуется с 2014 г. при поддержке Совета Федерации РФ, федеральных министерств природных ресурсов и культуры, Русского географического общества.

В здании Морского вокзала областного центра выставка будет работать до 1 декабря 2018 г., вход свободный для всех желающих. 
20 стран участниц

Крупнейшее событие 2018 в горной отрасли, которое посетят специалисты из Евросоюза, Китая, Индии, Вьетнама, Ирана, Сербии и других стран.

бonee

10000

организации неАропользователей,

промышленность, наука и

Участников

преАставитеАи органов власти

Регистрация на сайте https://evrazgeoforum.com/

С 2016 ВЕАУЩАЯ МЕЖАУНАРОАНАЯ ПАОЩААКА ААЯ ОБСУЖАЕНИЯ ИНТЕГРАЦИОННЫХ ПРОЦЕССОВ НА

СЫРЬЕВЫХ РЫНКАХ ЕВРАЗИИ

ТРЕТИЙ ЕвразИЙСКИЙ горновгеологический ФОРУМ |l $\begin{aligned} & \text { Республика Беларусь, Минск, } \\ & 14-16 \text { НОяБРя } 2018\end{aligned}$

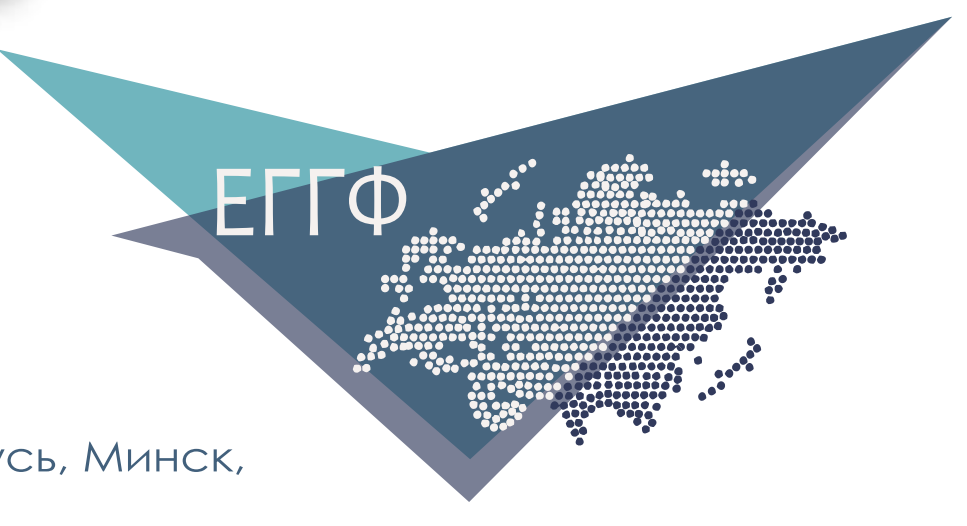

ОСНОВНАЯ ТЕМА 2018:

ЦИФРОВИЗАЦИЯ ГОРНОЙ ОТРАСАИ ААЯ СОВМЕСТНОГО РАЗВИТИЯ И ПРОЦВЕТАНИЯ В ЕВРАЗИИ

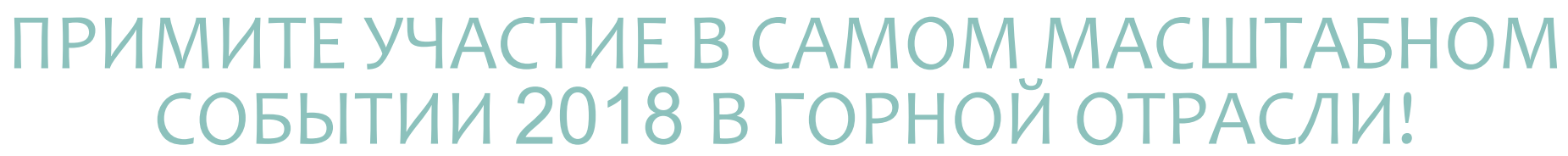

ВОЗМОЖЕН ВАРИАНТ ПОДКЛЮЧЕНИЯ ВАС КАК ИНТЕРАКТИВНОГО ОНЛАЙН-УЧАСТНИКА!

- Подключение к онлайн-трансляции из любой точки мира

- Интерактивный формат - возможность дискутировать с докладчиком

- Возможность обратить на себя внимание партнера или потенциального работодателя

- МАСТЕР-КЛАСС международных экспертов в сфере недропользования
- Возможность обратить на себя внимание потенциальных партнеров

- Список контактов участников Форума позволит вам завязать деловые знакомства напрямую

- Профессиональная запись всех заседаний форума

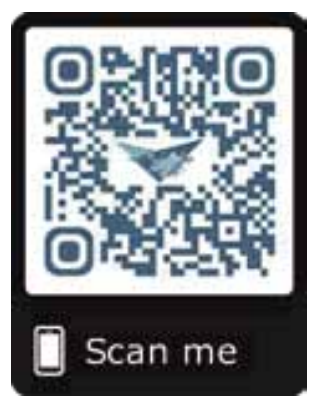

\section{Специальное предложение для читателей журнала «Уголь»:} ПРОМОкод \#еvrazgeoforum27 дает право на скидку 45\% на тариф ОНЛАЙН-участник.

ОРГАНИЗАТОРЫ ФОРУМА: Министерство природных ресурсов Республики Беларусь и ООО«Евразийская горно-геологическая группа» сайт https://evrazgeoforum.com/ E-mail: info@evrazgeoforum.com В социальных сетях: Facebook / Instagram / Telegram / Вконтакте ОФИЦИАЛЬНЫЕ группы Форума: EVRAZGEOFORUM
TEL / VIBER/ WHASAPP/ TELEGRAM +375 (29) 6762719; +7 (965) 1346288 


\section{КОСМИЧЕСКИЕ ТЕХНОЛОГИИ В УГОЛЬНОЙ ОТРАСЛИ}

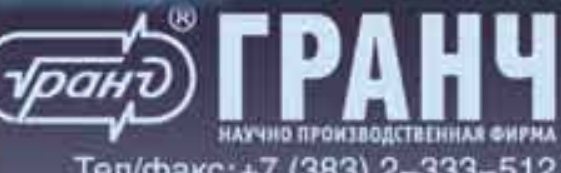

Ter/chakc: +7 (383) 2-333-512

E-mailinfo@granch.ru hitp://www.granch.ru

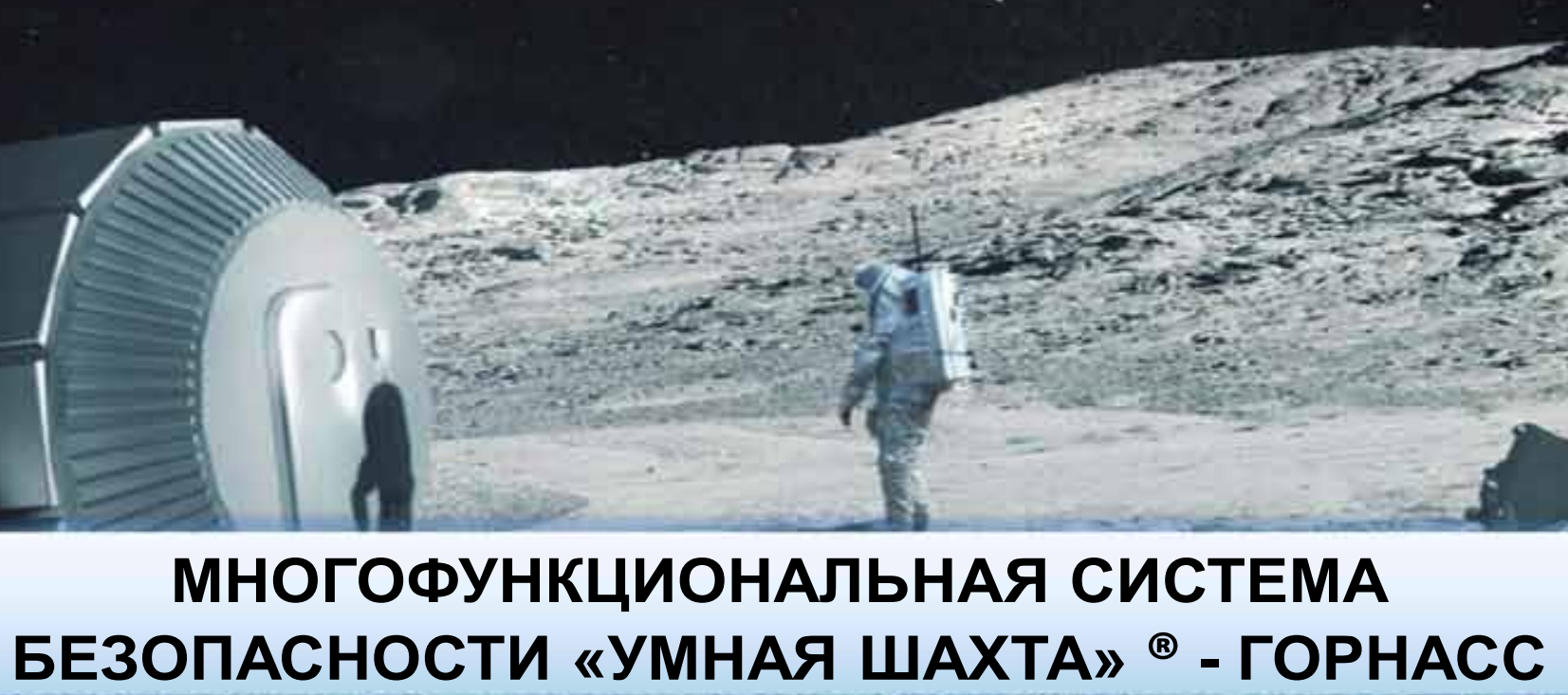

1 Мониторинг параметров работы шахты в режиме реального времени, включая:

- сканирующий (динамический) газовый контроль;

- позиционирование персонала и шахтного транспорта.

2 Аварийное оповещение персонала с автоматическим (контроль доставки) и ручным (контроль осознания) подтверждением получения сигнала.

3 Мобильная связь с использованием смартфона на платформе Android c возможностью проведения фото- и видеосъемки в шахте, в том числе в тепловизионном режиме.

4 Функционирование благодаря применению беспроводных технологий, после воздействия ударно-взрывной волны.

5 Передача данных в горных выработках с фантастической скоростью.

Система соответствует требованиям раздела 6 национального стандарта РФ ГОСТ P 55154-2012 «Оборудование горно-шахтное. Системы безопасности угольных шахт многофункциональные. Общие технические требования». 